\title{
Site U1341
}

\author{
Expedition 323 Scientists $^{2}$
}

\section{Chapter contents}

Background and objectives.......... 1

Operations................... 2

Lithostratigraphy.............. 3

Biostratigraphy .............. 5

Paleomagnetism .................. 11

Geochemistry and microbiology. . . . . . . 12

Physical properties .............. 14

Stratigraphic correlation. . . . . . . . . . 16

Downhole measurements . . . . . . . . . . 17

References................... 19

Figures................... 22

Tables..................... 76

'Expedition 323 Scientists, 2011. Site U1341. In Takahashi, K., Ravelo, A.C., Alvarez Zarikian, C.A., and the Expedition 323 Scientists, Proc. IODP, 323: Tokyo (Integrated Ocean Drilling Program Management International, Inc.). doi:10.2204/iodp.proc.323.105.2011

'Expedition 323 Scientists' addresses.

\section{Background and objectives}

The primary objective of drilling at Integrated Ocean Drilling Program (IODP) Site U1341 (proposed Site BOW-14B; Takahashi et al., 2009) was to study high-resolution Pliocene-Pleistocene paleoceanography at a western flank location of Bowers Ridge (Fig. F1) in the southern part of the Bering Sea. Previous Deep Sea Drilling Project (DSDP) coring (Site 188) and other piston core studies in the region documented relatively high sedimentation rates of 100 and $138 \mathrm{~m} / \mathrm{m}$.y., respectively, and the presence of appropriate microfossils for paleoceanographic studies. Bowers Ridge is well situated for study of the past extent of water mass exchange with the Pacific Ocean through adjacent Aleutian passes such as Amukta, Amchitka, and Buldir. In particular, its location allows for an examination of the influence of changes in the warm Alaskan Stream water mass that flows into this region and presumably impacted the distribution of past sea ice coverage. Although productivity in the Bering Sea in general is very high with respect to other parts of the global oceans (Takahashi et al., 2000), the expected productivity at this site is lower than at Site U1339, which is substantially more influenced by the adjacent Bering shelf, which was subaerially exposed during glacial lowstands. Drilling at this site, which is located at a relatively deep water depth of $2177 \mathrm{~m}$, allows for the study of past intermediate water conditions, including changes in the chemical composition of seawater. For example, this site is located just below the modern dissolved oxygen minimum zone (OMZ), which causes the formation of laminated sediments. Slight fluctuations in the intensity or depth of the OMZ should be captured by proxy records of past oxygenation measured at this site and compared to other, shallower sites. This site and the shallower drill sites on Bowers Ridge (IODP Site U1340, water depth $=1295 \mathrm{~m}$, and IODP Site U1342, water depth $=819 \mathrm{~m}$ ) will be used to compare the vertical extent of water mass conditions.

Site U1341 can also be used to study the impact of subseafloor microbes on biogeochemical fluxes in a region of high surface-ocean productivity in the Bering Sea. Organic-fueled subseafloor respiration and its impact on biogeochemistry in such a highly productive region have not previously been quantified. To do so, sediments drilled at Bowers Ridge were used to determine subseafloor cell abundances and were then subjected to intensive geochemical analysis to investigate the link between the mass and charac- 
teristics of subseafloor microbes and the extent of export productivity from the surface ocean.

Site U1341 is located on the western flank of the central part of Bowers Ridge (Fig. F1) in a depression (Fig. F2) $\sim 40 \mathrm{~km}$ west of the ridge crest. Close-ups of seismic images in the basin (Figs. F2, F3, F4, F5) indicate that strata dip gently to the west (Figs. F2, F4). Some shallow sections do not have continuous parallel strata, but most of the rest of the section appears to have continuous features in the seismic images (Figs. F4, F5). The ages of basement and the deeper sediments are unknown, but sediments as old as upper Miocene were found at Site 188 on the western flank of Bowers Ridge (Scholl and Creager, 1973). Specifically, Scholl and Creager (1973) found recent to upper Miocene diatom ooze interbedded with silt-rich diatom ooze and diatomaceous silt. They also found calcareous nannofossils in the uppermost $120 \mathrm{~m}$ and planktonic foraminifers in the uppermost $300-400 \mathrm{~m}$. They encountered mudstone in the interval between 580 and 638 meters below seafloor (mbsf). They reported sedimentation rates of $\sim 100 \mathrm{~m} / \mathrm{m}$.y. A piston core study from the same general region provided a sedimentation rate of $138 \mathrm{~m} /$ m.y. (Takahashi, 2005), which allows the study of high-resolution paleoceanography. Thus, before drilling we expected to recover Pleistocene to Pliocene sections.

\section{Operations}

A positioning beacon was deployed at Site U1341 at $2311 \mathrm{~h}$ on 26 July 2009 (all times are ship local time, Universal Time Coordinated [UTC] - $11 \mathrm{~h}$ ). Three holes were drilled at this site (Table T1). A complete set of site-specific tide tables was provided by the science party for Site U1341 and used to make adjustments relative to initial mudline core and for each successive core in each hole. A new continuous advanced piston corer (APC) coring depth record was established when Hole U1341B reached $458.4 \mathrm{~m}$ drilling depth below seafloor (DSF). Coring for Site U1341 totaled 139 cores, $1189.2 \mathrm{~m}$ penetrated, and $1210.3 \mathrm{~m}$ recovered, for $102 \%$ core recovery (Table T1). The time spent at Site U1341 was $170.5 \mathrm{~h}$ (7.1 days).

\section{Hole U1341A}

Hole U1341A was spudded at $0510 \mathrm{~h}$ on 27 July. The first APC barrel recovered $3.04 \mathrm{~m}$ of core, and an official seafloor depth was established at $2150.9 \mathrm{~m}$ drilling depth below rig floor (DRF). APC coring using nonmagnetic coring assemblies with the FlexIt orientation tool installed continued through Core 323U1341A-20H to $2334.4 \mathrm{~m}$ DRF. At this point, the nonmagnetic coring equipment was changed to the standard APC coring system and coring continued. Coring with the APC system was suspended after Core 323-U1341A-41H after two successive short, incomplete strokes of the core barrel. Overall core recovery for Hole U1341A using the APC coring system was 104\%, with $373.2 \mathrm{~m}$ recovered (Table T1).

\section{Hole U1341B}

The vessel was offset 20 m east of Hole U1341A, and Hole U1341B was spudded at $2245 \mathrm{~h}$ on 28 July. The first APC barrel recovered $8.7 \mathrm{~m}$ of core, and an official seafloor depth was established at $2150.9 \mathrm{~m}$ DRF. APC coring using nonmagnetic coring assemblies with the FlexIt orientation tool installed continued through Core 323-U1341B-18H to 166.7 m DSF. Coring with the APC system was suspended after Core 323-U1341B-56H after three successive short, incomplete strokes of the core barrel. A new continuous APC coring record was established with continuous piston cores from the mudline to $458.4 \mathrm{~m}$ DSF. The extended core barrel (XCB) coring system was then deployed for Cores 323-U1341B-57X through 71X. The hole was terminated after Core 323-U1341B-71X when the total depth of the hole reached $600.0 \mathrm{~m}$ DSF. APC core recovery for Hole U1341B was $102 \%$, with $467.64 \mathrm{~m}$ recovered. XCB core recovery for Hole U1341B was $88.2 \%$, with $126.9 \mathrm{~m}$ recovered. Total core recovery was $98.7 \%$, with $595.0 \mathrm{~m}$ recovered (Table T1). After coring, the coring tools were secured, and the hole was swept clean and displaced with $200 \mathrm{bbl}$ of high-viscosity logging mud. No fill was identified at total depth. The top drive was set back, and the drill pipe was tripped to $80 \mathrm{~m}$ DSF while the hole was monitored for problems. The end of pipe was placed at $\sim 80.0$ m DSF. Rig-up for wireline logging began at $1930 \mathrm{~h}$ on 31 July. Two logging strings were deployed. The triple combination (triple combo) tool string reached the total hole depth of $600 \mathrm{~m}$ wireline log depth below seafloor (WSF), and good-quality logs were obtained. The second logging string consisted of the Formation MicroScanner (FMS)-sonic tool. This tool string also reached the total depth of $600 \mathrm{~m}$ WSF and also obtained good data on both passes. Wireline logging in Hole U1341B was successfully concluded and all logging equipment was rigged down by $1530 \mathrm{~h}$ on 1 August.

\section{Hole U1341C}

Operations in Hole U1341C commenced at $1555 \mathrm{~h}$ on 1 August. The vessel was moved $20 \mathrm{~m}$ east of Hole U1341B, and Hole U1341C was spudded at $1810 \mathrm{~h}$. The first APC barrel recovered $5.5 \mathrm{~m}$ of core, and an official seafloor depth was established at $2150.9 \mathrm{~m}$ DRF. APC coring using nonmagnetic coring assem- 
blies with the FlexIt orientation tool installed continued through Core 323-U1341C-17H to $147 \mathrm{~m}$ DSF. At this point, standard steel core barrels were installed, and coring continued through Core 323U1341C-27H to $230 \mathrm{~m}$ DSF. Overall APC core recovery was $242.06 \mathrm{~m}$ (106.2\%) (Table T1).

\section{Lithostratigraphy}

Three holes were drilled at Site U1341; the deepest, Hole U1341B, reached 601.87 mbsf $(621.82 \mathrm{~m}$ core composite depth below seafloor [CCSF-A]). The sediments recovered at Site U1341 are a mixture of diatoms and siliciclastic sediments with minor amounts of ash, foraminifers, calcareous nannofossils, and sponge spicules. The sediments are predominantly very dark greenish gray to dark gray or dark gray to olive-gray to light olive in color. Authigenic carbonates occur frequently at this site below $130 \mathrm{mbsf}$. Three lithologic units were defined at Site U1341, and Unit III was further divided into two subunits (Fig. F6). The Unit I/II boundary is defined by a major lithologic change from sediments dominated by laminated diatom ooze to sediments that alternate between diatom silt/clay and diatom ooze. The boundary between the two units occurs with a significant increase in magnetic susceptibility at 205 mbsf in Hole U1341B and is early Pleistocene in age. The boundary between Unit II and Subunit IIIA is defined by a change in lithology from clays rich in authigenic carbonates to mostly diatom ooze. Subunit IIIB consists of alternations between diatom clay and diatom ooze. The bottom of Hole U1341B reaches the middle Pliocene.

\section{Description of units}

The most abundant terrigenous grain types are siltsized feldspar, quartz, clay, mica, and rock fragments (mainly polycrystalline quartz; see also "Site U1341 smear slides" in "Core descriptions"). Pebble-sized clasts occur frequently throughout this site and are often composed of basalt, pumice, or scoria. Ash layers occur less frequently than at Site U1340 on the eastern side of Bowers Ridge. These ash layers are typically black, light gray, dark reddish gray, or light reddish gray. Volcaniclastic grains are often mixed with biogenic and siliciclastic sediments through bioturbation.

Dolostones and micrometer-scale crystals of authigenic carbonate occur below 130 mbsf in all holes at Site U1341. Authigenic carbonate patches, nodules, and layers are light olive-gray and olive-gray, are often characterized by a granular texture, and are more indurated than surrounding sediments.
Intervals with soft-sediment deformation are less common than at Site U1340 and are largely confined to Cores $2 \mathrm{H}$ and $3 \mathrm{H}$ in all holes. Deformation appears as folded and tilted bed boundaries, suggesting synsedimentary slumping as a potential mechanism. Some deformation occurs deeper in holes without significant disturbance to the overall stratigraphic relationships of the sediments.

Clasts occur from 0 to 400 mbsf with no apparent patterns in distribution. The clasts are mostly pebble-sized, vary from angular to rounded, and are volcanic or volcaniclastic in origin. However, in Cores 323-U1341B-57X and 58X, many dolostone concretions occur in an interval of clay lithology. This interval is described more fully below in the description of Unit III. In the database and summary figures, these concretions were sometimes classified as clasts, although an authigenic origin is likely, because authigenic carbonates were observed in smear slides from these cores.

The core tops from Core 323-U1341B-25H and deeper often contain a mixture of black basalt clasts and whitish carbonate clasts. These clasts are not in place and fell in from the hole walls during coring. Clasts were also sometimes observed along the core liner and were probably pushed there during the coring process. These clasts were recorded in the database not as clasts but as the drilling disturbance type "fall-in" because they are apparently not in place.

Boundaries between different sediment colors and/or lithologies are dominantly gradational and bioturbated, but occasional sharp contacts occur as well. Variations in color and lithology can generally be described as irregular bedding on a decimeter to meter scale in all holes and at all depths. Intervals with thin, distinct parallel laminations are confined to Unit I (Fig. F7B). In all units there are thickly laminated to thinly bedded intervals that have undulating or wavy boundaries that are slightly to moderately bioturbated (Fig. F7A). Sequences with no visible bioturbation are massive and may be intensely bioturbated. Individual burrows are not often well preserved, and hence bioturbation cannot be related to specific ichnofacies types in most cases. Where visible, bioturbation was mostly assigned to the Chondrites ichnofacies with minor Skolithos and Planolites.

\section{Unit I}

Intervals: Sections 323-U1341A-1H-1, $0 \mathrm{~cm}$, through $24 \mathrm{H}-3,90 \mathrm{~cm} ; 323-\mathrm{U} 1341 \mathrm{~B}-1 \mathrm{H}-1,0 \mathrm{~cm}$, through $24 \mathrm{H}-1,0 \mathrm{~cm}$; and $323-\mathrm{U} 1341 \mathrm{C}-1 \mathrm{H}-1,0$ $\mathrm{cm}$, through $25 \mathrm{H}-5,90 \mathrm{~cm}$ 
Depths: Hole U1341A, 0.0-215.9 mbsf; Hole U1341B, 0.0-209.20 mbsf; and Hole U1341C, 0.0-208.4 mbsf

Age: Pleistocene

This unit is characterized by an alternation between diatom ooze, mixed lithologies of diatoms with clay/ silt, and silt/clayey silt (see "Site U1341 smear slides" in "Core descriptions"). The sediment color ranges from dark greenish gray (10Y 4/1) to dark olive (5Y 4/1) and from dark grayish brown (5Y 4/2) to olive (5Y 5/4). The alternation occurs on a decimeter to meter scale. In addition, this unit has intervals with abundant calcareous nannofossils, foraminifers, or sponge spicules. These microfossils tend to be most abundant in light-colored laminae within laminated intervals and also within some patches or burrows. There is an interval in Cores $9 \mathrm{H}$ and $10 \mathrm{H}$ in all holes where nannofossils are notably abundant (5\%$40 \%)$ and the sediment is slightly lighter colored (light gray, 10YR 7/1), with more intensely bioturbated boundaries with surrounding units (Fig. F7).

Intervals with thin parallel laminations are usually $5-30 \mathrm{~cm}$ thick and can sometimes be correlated between holes. In this unit, thick laminations and thin bedding are common and frequently very faint, and there are instances, such as in Core $12 \mathrm{H}$ in all holes, where different observers judged sediment that otherwise appears identical as having laminations, bedding, or neither. This can account for the differences in the recorded occurrence of laminations and bedding between holes.

\section{Unit II}

Intervals: Sections 323-U1341A-24H-3, $90 \mathrm{~cm}$, through 41H-CC, $23 \mathrm{~cm}$; 323-U1341B-24H-1, 0 $\mathrm{cm}$, through 57X-CC, $29 \mathrm{~cm}$; and 323-U1341C$25 \mathrm{H}-5,90 \mathrm{~cm}$, through 27H-CC, $27 \mathrm{~cm}$

Depths: Hole U1341A, 215.9-359.12 mbsf; Hole U1341B, 209.20-467.33 mbsf; and Hole U1341C, 208.4-230.54 mbsf

Age: mid-Pliocene to late Pleistocene

The dominant lithology in this unit is diatom ooze, with one interval in Hole U1341B (Cores 37H through $46 \mathrm{H}$ ) dominated by diatom clay. The diatom ooze is dark grayish brown $(2.5 \mathrm{Y} 4 / 2)$, dark greenish gray (10Y 4/1), dark olive-green (5Y 4/1), and olive-gray (5Y 4/2). The diatom clay is mostly dark greenish gray (10Y 4/1). In contrast to Unit I, calcareous microfossils never reach concentrations $>5 \%$, but sponge spicules and sponge spicule aggregates are abundant $(>5 \%)$ in a few intervals (see also "Site U1341 smear slides" in "Core descriptions"). Laminations and thin bedding are pervasive throughout Unit II and occur more frequently than in Units I or III.

\section{Unit III}

\section{Subunit IIIA}

Interval: Sections 323-U1341B-57X-CC, $29 \mathrm{~cm}$, through 58X-5, $20 \mathrm{~cm}$

Depth: Hole U1341B, 467.33-473.90 mbsf

Age: mid-Pliocene

This subunit consists of olive (5Y 5/3) silty clay and is distinguished from Unit II by a sharp change in lithology. The silty clay contains finely disseminated authigenic carbonates, numerous angular pebblesized authigenic carbonate concretions, and two dolostone layers (Fig. F8B). Significant concentrations of sponge spicules are not observed in this interval, although they make up 5\%-10\% of the sediments in the lithologies immediately above and below (see "Site U1341 smear slides" in "Core descriptions").

\section{Subunit IIIB}

Interval: Sections 323-U1341B-58X-5, $20 \mathrm{~cm}$, through 71X-CC, $28 \mathrm{~cm}$

Depth: Hole U1341B, 473.90-601.87 mbsf

Age: mid-Pliocene

This subunit consists of alternations between light olive-gray (5Y 6/2) and olive-gray (5Y 4/2) diatom ooze and diatom silty clay. Sponge spicule aggregates were frequently observed, and sponge spicules are abundant (>5\%) in a few intervals (see "Site U1341 smear slides" in "Core descriptions"). There are occasional narrow intervals with faint reddish or brownish laminations in this unit. Authigenic carbonates occur in one interval within this subunit in Cores 323-U1341B-62X through 64X.

\section{Discussion}

Unit I at this site spans the same time period as Unit I at other sites. Units II and III at Site U1341 appear to span the same time periods as Units II and III at Site U1340, and there are also similarities in the lithologies of Sites U1341 and U1340. Unit I at both sites consists of alternating diatom ooze and mixed diatom-siliciclastic lithologies. Unit II is mostly diatom ooze, with an interval centered at $\sim 2.5$ Ma dominated by mixed diatom-siliciclastic lithologies (silt at Site U1340 and clay at Site U1341), and Subunit IIIA contains an interval just below the $3.8 \mathrm{Ma}$ datum (see also "Paleomagnetism" and "Biostratigraphy" both in the "Site U1340" chapter) that is dominated by siliciclastic lithologies (sand in Site U1340 and clay in Site U1341).

The similarities in lithology and age between Sites U1341 and U1340 suggest broadly similar changes in sedimentation history. However, there are also some interesting differences. The intervals where clasts are observed are similar at the two sites, but clasts are 
notably more abundant in Unit I at Site U1340. There is no similar increase in clast abundance in Unit I of Site U1341. The laminations and bedding characteristics of Unit II at Site U1341 are similar in appearance to those in Unit II at Site U1340. At both sites, the laminations and bedding are particularly pervasive during the siliciclastic-rich interval in Unit II. The frequency of thin, parallel laminations in Unit I at Site U1341 appears to be lower than in Unit I at Site U1340, but as discussed above, it is possible that this is an artifact of the faintness of some laminations and of inconsistency in how these features were recorded.

The occurrence of soft-sediment deformation related to slumping was less extensive at Site U1341 than at Site U1340, but the deformation may have the same trigger mechanism (see "Lithostratigraphy" in the "Site U1340" chapter). Ash layers at Site U1341 were a less prominent feature than at Site U1340, perhaps reflecting the more distal location of Site U1341 to the Aleutian arc. Ash-filled mottles and dispersed ash may have originally been thin ash layers that were mixed with the surrounding sediment through bioturbation.

Low gamma ray attenuation (GRA) bulk density broadly correlates with high diatom abundance (Figs. F6, F9, F10). Diatom ooze may reflect interglacial conditions, whereas mixed diatom-siliciclastic lithologies may reflect glacial conditions. This is consistent with the pattern of biogenic opal mass accumulation rates (MARs) observed in piston cores from the Bering Sea (Katsuki and Takahashi, 2005).

The diatom clay lithology in Unit II represents a period of relatively high siliciclastic grain deposition at Site U1341, perhaps reflecting the onset of glaciation in the Bering Sea and surrounding continental areas. The increase in clay in this interval is also visible in the logging data as higher natural gamma radiation (NGR) and potassium and was defined as logging Unit 3 (see "Downhole measurements"). The lithologies in Unit I are richer in diatoms, and the siliciclastic grains are dominated by silt rather than clay, leading to lower NGR and potassium signals.

The increase in magnetic susceptibility at the base of Unit I may reflect a change in the nature or preservation of magnetic grains deposited at Site U1341 after 1.6 Ma (see "Paleomagnetism"). Coarser grains may be better preserved in the sediment, thereby delivering a stronger magnetic signal after 1.6 Ma. If coarser grains were transported by ice rafting, this would reflect the intensification of glaciations after 1.6 Ma.

An interesting feature of Site U1341 is the occurrence of sediment intervals rich in nannofossils (Fig. F11). Calcareous nannofossils are rare in the sedi- ments drilled at IODP Expedition 323 sites, with the exception of Site U1341, where a small interval of nannofossil-diatom ooze was recovered in all holes. This sudden increase in nannofossil abundance is associated with increased foraminifer abundance and may be explained by increased productivity, increased carbonate preservation, or both. The calcareous nannofossil assemblage is dominated by small gephyrocapsids and includes specimens of the heavily calcified Gephyrocapsa caribbeanica and Coccolithus pelagicus. Increased calcareous nannofossil preservation at the seafloor may be due partially to the heavy calcification of Gephyrocapsa coccoliths (see "Biostratigraphy").

Below 200 mbsf, the presence of authigenic carbonate crystals and dolostones suggests diagenetic carbonate precipitation as a result or by-product of microbial activity. The coincidence of authigenic carbonates, nodules, and dolostones with the silty clay lithology in Subunit IIIA is intriguing. It is not clear what mechanisms could have caused this relationship.

\section{Biostratigraphy}

Core catcher samples from Site U1341 are dominated by highly diverse diatom microfossil assemblages. The samples also contain assemblages of radiolarians, calcareous nannofossils, foraminifers, and organic-walled microfossils with medium to high diversity. The preservation of different microfossil groups ranges from moderate to very good. Biostratigraphic datums were derived from diatom, radiolarian, calcareous nannofossil, dinoflagellate, ebridian, and silicoflagellate bioevents that indicate Site U1341 contains early Pliocene to Holocene sediments. However, the presence of early Pliocene species indicates that some reworking has occurred within the uppermost $\sim 20 \mathrm{~m}$. In all, 23 bioevents were identified (Fig. F12; Table T2).

Both Holes U1341A and U1341B exhibit broadly linear sedimentation rates. Siliceous microfossils occur consistently throughout the section and are mainly composed of high-latitude pelagic species that indicate changes in surface water productivity. Calcareous microfossils are mostly confined to the top of the section above 250 m CCSF-A for nannofossils and $280 \mathrm{~m}$ CCSF-A for planktonic foraminifers. Below these levels, only sporadic occurrences of calcareous fossils and calcareous cemented agglutinated foraminifers were detected, which may be linked to changes in preservation. Dinoflagellates consistently occur throughout the section, indicating changes in the productivity and the sea ice cover of the surface waters. 


\section{Calcareous nannofossils}

All core catcher samples from Holes U1341AU1341C were sampled and examined for calcareous nannofossils to assess overall abundance, state of preservation, and abundance by taxa (Table T3). As at IODP Sites U1339 and U1340, calcareous nannofossils are a minor component of the recovered sediments, except in small intervals, and their abundance is generally low, with frequent barren intervals, particularly in the lower parts of the sequence (Fig. F13). Calcareous nannofossil preservation ranges from good to moderate, except for the following samples that contain poorly preserved specimens: $323-\mathrm{U} 1341 \mathrm{~B}-14 \mathrm{H}-\mathrm{CC}$ and $46 \mathrm{H}-\mathrm{CC}$ and 323-U1341C-12H-CC and 16H-CC. Coccolithus pelagicus is present throughout the studied interval, although small and medium gephyrocapsids and small reticulofenestrids (small Dictyococcites spp.) dominate some of the assemblages present. Reworked specimens are not a major component of the sediments at this site, and only a few individuals of Pliocene age were observed.

The frequency and importance of barren intervals in the calcareous nannofossil record of Site U1341 prevented accurate age determinations in most cases, but some periods were identified. The occurrence of Emiliania huxleyi in Samples 323-U1341A-1H-CC and 3H-CC, 323-U1341B-1H-CC, and 323-U1341C-4HCC allowed assignment of the intervals containing those samples to calcareous nannofossil Zone NN21 of Martini (1971), defined by the first occurrence (FO) datum of E. huxleyi at $0.29 \mathrm{Ma}$. This taxon is usually represented by the small $(<4 \mu \mathrm{m})$ morphotype, but well-preserved larger specimens $(>4 \mu \mathrm{m})$ also occur, mainly in Sample 323-U1341B-1H-CC.

Calcareous nannofossil Zone NN20 and the top of Zone NN19 can be well constrained only in Hole U1341C (Table T3), where no barren samples occur between the FO of E. huxleyi in Sample 323-U1341C4H-CC and the last occurrence (LO) datum of Pseudoemiliania lacunosa in Sample 323-U1341C-6H-CC, establishing an age older than $0.44 \mathrm{Ma}$ for the latter. However, the occurrence of a characteristic $25 \mathrm{~cm}$ thick nannofossil ooze layer in Core 323-U1341C$8 \mathrm{H}$, which was also recovered in Cores 323-U1341A$8 \mathrm{H}$ and $323-\mathrm{U} 1341 \mathrm{~B}-8 \mathrm{H}$ (see below), indicates that the top of Zone NN19 is located in Holes U1341A and $\mathrm{U} 1341 \mathrm{~B}$, at least on the top sections of these cores.

In older sediments, the combination of barren intervals with the absence of marker taxa prevented the application of Martini (1971) zonal schemes and the assignment of ages to all samples. However, the changes observed in the composition of calcareous nannofossil assemblages between Samples 323U1341B-36H-CC (dominated by C. pelagicus) and 52H-CC (predominantly Dictyococcites spp. and Reticulofenestra minuta) are similar to those recorded at nearby DSDP Site 883 by Sato et al. (2002), who indicated that the reversal in abundance between these taxa marks the onset of heavy glaciations in the Northern Hemisphere and dated this horizon (their Datum Plane A) to $2.75 \mathrm{Ma}$. According to this information, Samples 323-U1341B-52H-CC and below are older than $2.75 \mathrm{Ma}$. Independent dating by means of diatom, radiolarian, and silicoflagellate biostratigraphy as well as preliminary chronomagnetostratigraphic results for this site is consistent with this estimation (Fig. F12).

As stated above, the frequent occurrence of barren intervals, which sometimes last for tens of meters, is a major feature of the sequences obtained at Site U1341 and could probably be correlated to the lowermost $400 \mathrm{~m}$ recovered from Hole U1340A. In most cases, calcareous nannofossils and planktonic foraminifers (and, to a lesser extent, benthic foraminifers) are equally affected, indicating a preservational imprint on the carbonate signal with a probable association with authigenic dolomites. However, transient high-productivity intervals of carbonate-walled organisms should not be discounted as the cause of the occurrence of carbonate-rich horizons within the recovered sequence such as the thin $(\sim 25 \mathrm{~cm})$ nannofossil ooze layer observed in all three holes drilled at Site U1341 (intervals 323-U1341A-8H-7, $10 \mathrm{~cm}$; 323-U1341B-8H-3, 60-80 cm; and 323-U1341C$8 \mathrm{H}-5,146 \mathrm{~cm}$ ) (Table T3). This ooze is characterized by high numbers of coccoliths and an assemblage dominated by small gephyrocapsids, and it displays abundant heavily calcified specimens of G. caribbeanica and $C$. pelagicus. The occurrence of $P$. lacunosa above the ooze layer (Core 323-U1341C-6H) and the occurrence of the Brunhes/Matuyama Chron boundary below it (Cores 323-U1341A-10H, 323-U1341B$9 \mathrm{H}$, and $323-\mathrm{U} 1341 \mathrm{C}-10 \mathrm{H})$ indicate that sedimentation of the layer occurred between 0.44 and $0.78 \mathrm{Ma}$. The acme interval of $G$. caribbeanica is a well-known event that takes place in most oceans between marine isotope Stages (MIS) 14 and 8 (Flores et al., 2003) and may have started even before at mid-MIS 15 in the northeast Atlantic (Hine, 1990). Therefore, an age range of $0.44-0.6 \mathrm{Ma}$ is suggested for this calcareous nannofossil ooze layer. The proliferation of $G$. caribbeanica in the oceans has been suggested as a possible cause of the mid-Brunhes dissolution inter- 
val in the oceans (Barker et al., 2006), centered on MIS 11. Therefore, shore-based research on the origin of this ooze will be of great interest.

\section{Planktonic foraminifers}

Planktonic foraminifers ( $>125 \mu \mathrm{m})$ were studied in all core catcher samples from Holes U1341A-U1341C (Table T4). Three mudline samples from the tops of Cores 323-U1341A-1H, 323-U1341B-1H, and 323U1341C-1H were also analyzed. All residues are dominated by either diatoms or siliciclastics. Sponge spicules were also observed in the samples. The late Pleistocene fauna at Site U1341 is dominated by Neogloboquadrina pachyderma (sinistral), reflecting late Pleistocene cooling. This species is the most abundant taxon in the modern Bering Sea (Asahi and Takahashi, 2007). A small number of subpolar species, including Globigerina bulloides, Globigerina umbilicata, and Neogloboquadrina pachyderma (dextral), were also found in the late Pleistocene fauna. Below $\sim 150 \mathrm{~m}$ CCSF-A, planktonic foraminifer faunas are occasionally dominated by the subpolar species $G$. bulloides, G. umbilicata, and N. pachyderma (dextral), which indicates warmer sea-surface temperatures because these subpolar species are strongly temperature dependent (e.g., Bé and Tolderlund, 1971). No planktonic foraminifers were found below $\sim 300 \mathrm{~m}$ CCSF-A, except for Samples 323-U1341A-35H-CC and 38H$\mathrm{CC}$ and 323-U1341B-36H-CC and 61X-CC from the late Pliocene $(\sim 2.5 \mathrm{Ma})$. Only subpolar species were found in these samples. Globigerina uvula appears in high numbers in Sample 323-U1341B-36H-CC. This species is relatively widespread in high-latitude oceans (Saito et al., 1981) and has been found on the shelf of Norway and the Barents Sea, where it tolerates slightly low salinities (34-35) (e.g., Husum and Hald, 2004). Preliminary studies in the Bering Sea indicate that G. uvula also tolerates slightly low salinities in this region (H. Asahi, pers. comm., 2009).

\section{Benthic foraminifers}

Around 60 species of benthic foraminifers were identified in 140 samples from Holes U1341A-U1341C (Tables T5, T6, T7). Assemblages from the tops of the sections down to around Sample 11H-CC in all holes are of relatively high diversity and abundance, showing affinities to assemblages within or near the OMZ in the Sea of Okhotsk (Bubenshchikova et al., 2008), and are also partially composed of more common deepwater Pacific Ocean species (Butt, 1980). In the remainder of the cores, benthic foraminifers are less abundant and the agglutinated species Eggerella bradyi and Martinottiella communis are more important components of the assemblages, indicating significant dissolution of calcareous material.
Assemblage I (Globobulimina pacifica-Uvigerina)

Assemblage I is characterized by high-diversity and high-abundance faunas between Samples $1 \mathrm{H}-\mathrm{CC}$ and $11 \mathrm{H}-\mathrm{CC}$ in all holes, with persistent occurrences of the species Globobulimina pacifica, Uvigerina auberiana, Gyroidinoides soldanii, and Islandiella norcrossi. Other common species include Bulimina aff. exilis, Melonis barleeanum, and Pullenia bulloides. Fluctuations in the dominance of deep and shallow infaunal species occur and are most likely related to changes in the extent of bottom water oxygen concentrations associated with changes to the OMZ.

\section{Assemblage II (Eggerella bradyi)}

Assemblage II consists of medium- to low-diversity faunas between Samples 12H-CC and 37H-CC in all holes, characterized by the relatively persistent occurrence of $E$. bradyi. Other common species include G. pacifica, G. soldanii, Epistominella pulchella, and $P$. bulloides. This interval may be affected by dissolution because other calcareous microfossil groups are less abundant.

\section{Assemblage III (depauperate)}

The major characteristic of Assemblage III is the high number of barren samples between Samples 38H-CC and $45 \mathrm{H}-\mathrm{CC}$ in all holes. E. bradyi occasionally occurs.

\section{Assemblage IV (Martinottiella communis)}

This low-diversity and low-abundance assemblage contains relatively continuous occurrences of $M$. communis and, to a lesser extent, E. bradyi between Samples 46H-CC and 71H-CC in all holes. Other species occasionally present are G. soldanii, Lenticulina spp., M. barleeanum, and Uvigerina spp. Samples $61 \mathrm{H}-$ $\mathrm{CC}$ and $62 \mathrm{H}-\mathrm{CC}$ in all holes have relatively high diversity and abundance. $M$. communis has been recorded in low-oxygen intermediate waters off the Pacific coast of Japan (Kaiho and Hasegawa, 1986), where oxygen levels are somewhat higher than those in the modern Bering Sea bottom water at this site.

\section{Ostracodes}

Ostracodes are extremely rare at Site U1341, and only four specimens were found in the interval between Samples 323-U1341A-9H-CC and 35H-CC (Table T5). Despite their very low numbers, ostracode valves are large and very well preserved, suggesting that dilution by high diatom abundance took place. Three species were identified: Henryhowella dassiderma, Bradleya normani, and Cytheropteron massoni. Species of Henryhowella are epifaunal and have worldwide distribution in water depths ranging from 
500 to $5000 \mathrm{~m}$ (Ayress et al., 2004; Yasuhara et al., 2008). The highest relative abundances of Henryhowella and Bradleya were recorded during interglacials at deep North Atlantic sites that are influenced today by North Atlantic Deep Water (NADW) (Cronin et al., 1999; Didié and Bauch, 2000, 2002; Alvarez Zarikian et al., 2009). The glacial-interglacial distribution of the species at these sites suggests that they prefer adequate food supply and well-oxygenated bottom waters. The genus Cytheropteron has worldwide distribution but the highest species diversity in cold waters (Ayress et al., 2004; Stepanova, 2006). In the North Atlantic, the highest occurrences of Cytheropteron are associated with deglacial transitions (Cronin et al., 1999; Alvarez Zarikian et al., 2009).

\section{Diatoms}

Diatom biostratigraphy is based on analysis of core catcher samples from Holes U1341A and U1341B. Depth positions and age estimates of biostratigraphic marker events are shown in Table T2. Diatoms are the dominant microfossil in all holes and show good preservation throughout (Tables T8, T9).

A biostratigraphic zonation was constructed back to the early Pliocene for both Holes U1341A and U1341B. Reworking was observed in the uppermost three cores (to $22.3 \mathrm{mbsf}$ ) of Hole U1341A and the uppermost two cores (to $18.5 \mathrm{mbsf}$ ) of Hole U1341B, which contain species from both the early Pleistocene and Pliocene.

The LOs of Proboscia curvirostris, Thalassiosira jouseae, and Proboscia barboi were identified in Sample 323U1341A-5H-CC (36.39 mbsf), and only P. curvirostris and $T$. jouseae were identified in Sample 323U1341B-4H-CC (32.83 mbsf), giving a composite estimated age of $0.3 \mathrm{Ma}$. Although the LO of P. curvirostris is set at $0.28 \mathrm{Ma}$ in the Bering Sea (Barron and Gladenkov, 1995), in the subarctic Pacific and around Japan the datum is defined at $0.3 \mathrm{Ma}$ (Barron and Gladenkov, 1995; Yanagisawa and Akiba, 1998) (see "Diatoms" in "Biostratigraphy" in the "Site U1339" chapter for further discussion). Cores above 323-U1341A-5H were assigned to the Neodenticula seminae Zone of $0.3 \mathrm{Ma}$ and younger. This datum is closely matched in Hole U1341B in Sample 323U1341B-4H-CC. The assemblage is dominated by $N$. seminae, Actinocyclus curvatulus, Thalassiosira spp. (i.e., Thalassiosira latimarginata s.l., Thalassiosira antarctica spores, and, to a lesser extent, Thalassiosira nordenskioeldii), Actinocyclus ochotensis, Odontella aurita, and Porosira glacialis.

The following age of $0.9 \mathrm{Ma}$ in Hole U1341A is defined by the last common occurrence (LCO) of Actinocyclus oculatus in Sample 323-U1341A-15H-CC.
The corresponding datum in Hole U1341B was established in Sample 323-U1341B-13H-CC; however, this species is not as abundant in this hole, making age determination more difficult. The assemblage for the A. oculatus Zone in Hole U1341B is dominated by $N$. seminae, A. curvatulus, $P$. curvirostris, Thalassiosira spp. (i.e., T. latimarginata s.l., T. antarctica spores, and T. oestrupii), Rhizosolenia barboi, and Coscinodiscus marginatus, along with the less common taxon Thalassiothrix longissima.

The $A$. oculatus Zone is constrained by the LCO of Neodenticula koizumii $(2.1 \pm 0.1 \mathrm{Ma})$. In Hole U1341A this datum is set in Sample 323-U1341A-23H-CC and co-occurs in Hole U1341B in Sample 323-U1341B$23 \mathrm{H}-\mathrm{CC}$. This zonation in Holes U1341A and $\mathrm{U} 1341 \mathrm{~B}$ is further supported by the LO of secondary order datum Stephanopyxis horridus and the LCO of Thalassiosira antiqua (1.7-2.0 Ma). In Hole U1341A the assemblage is composed mainly of N. koizumii, A. curvatulus, Thalassiosira spp. (i.e., T. latimarginata s.l. and T. oestrupii), and C. marginatus, along with the less common taxon $T$. longissima. A similar assemblage is observed in Hole U1341B, with the addition of $S$. horridus.

The LCO of Neodenticula kamtschatica in Sample 323U1341B-41H-CC defines the next biostratigraphic zone at 2.7 Ma. This species is not observed in Hole U1341A, which indicates that the bottom of the hole is younger than $2.7 \mathrm{Ma}$. The assemblage composition in Hole U1341B is dominated by N. kamtschatica, $N$. koizumii, Actinocyclus spp. (A. curvatulus, A. ochotensis, and A. oculatus), Thalassiosira spp. (T. latimarginata s.l., T. oestrupii, and T. antiqua), S. horridus, Stephanopyxis turris, and, to a lesser extent, T. longissima and Thalassiosira eccentrica.

The datums and subsequent age model were further confirmed by comparison between the relative abundance of $N$. seminae and $N$. kamtschatica in both Holes U1340A and U1341B (Fig. F14). This correlation technique using tie points to match similar events in the two records was applied to confirm and support the age models at Sites U1340 and U1341, following the difficulties encountered with the identification of the FO and LO of N. seminae and N. koizumii. It is evident in Hole U1341B that $N$. seminae appears sporadically in older sediments but reveals a rapid increase (RI) that is mirrored in Hole U1340A. A similar correlation occurs for $N$. kamtschatica at both Sites U1340 and U1341, whereby an abrupt decrease in abundance (or rapid decrease [RD]) in Hole U1340A is matched in Hole U1341B.

The newly termed RI of $N$. seminae abundance co-occurs with the top of a paleomagnetic datum-the Olduvai section-giving a date of 1.778 Ma to Sam- 
ple 323-U1341B-22H-CC. This event was matched in Hole U1340A, and the same datum was extrapolated (see "Biostratigraphy" in the "Site U1340" chapter for further discussion). The RD of $N$. kamtschatica was also matched to Hole U1340A, where the abrupt decrease coincides with the paleomagnetic Gauss Event, giving a subsequent datum of $2.581 \mathrm{Ma}$. (see "Biostratigraphy" in the "Site U1340" chapter for further details).

An age of 3.7-3.9 Ma was assigned to Sample 323U1341B-51H-CC by the first common occurrence (FCO) of N. koizumii. The remainder of Hole U1341B from Samples 323-U1341B-51H-CC through 71X-CC was defined as the $N$. kamtschatica Zone. The absence of Rouxia californica and the secondary order datums Thalassiosira praeoestrupii, Cosmiodiscus insignis, and Thalassiosira temperei signifies that the bottom of Hole U1341B does not enter North Pacific Diatom (NPD) Zone $7 \mathrm{Ba}(6.6 \mathrm{Ma})$. The assemblage for this zone is typified by N. kamtschatica and by the heavily silicified species $C$. marginatus, Stephanopyxis spp. (S. horridus, S. turris, and Stephanopyxis zabelinae), and, to a lesser extent, T. latimarginata s.l., and $T$. longissima.

Overall, the datums show a consistent offset of 100200 k.y. compared to the paleomagnetic datums (Fig. F12), suggesting that the marker species in this region are diachronous. Therefore, a major revision of the biostratigraphic zonation will be required for this region.

\section{Silicoflagellates and ebridians}

Silicoflagellate and ebridian counting was conducted in Holes U1341A and U1341B (Tables T10, T11). The general trend of silicoflagellate and ebridian abundances at this site is similar to that at Site U1340. Five certain datums and one uncertain datum were estimated at this site based on the silicoflagellate and ebridian zonation established by Ling $(1973,1992)$ (Table T2). The youngest datum event, the LO of silicoflagellate Distephanus octonarius, is uncertain because of the limited silicoflagellate abundance and the significant influence of reworked materials in the uppermost three or four cores in both holes. Suggested reworked silicoflagellates in these cores are as follows: Bachmannocena apiculata (LO: late Miocene) in Sample 323-U1341B-4H-CC, Corbisema cf. hastata cunicula (LO: Pliocene?) in Sample 323-U1341B-3HCC, and Dictyocha subarctios (LO: 0.7 Ma) in Sample 323-U1341B-2H-CC. The LO of silicoflagellate $D$. subarctios was estimated in Sample 323-U1341A-7HCC (50.95-60.41 mbsf) but is uncertain in Hole U1341B because of the species' limited abundance and sporadic occurrence. The next oldest datum is the LO of ebridian Ammodochium rectangulare, which suggests an age of 1.9 Ma. This event was estimated in Samples 323-U1341A-27H-CC (233.21-241.4 mbsf) and 323-U1341B-26H-CC (228.52-238.11 mbsf). The LO of ebridian Ebriopsis antiqua antiqua was found in Samples 323-U1341A-37H-CC (328.09$332.81 \mathrm{mbsf}$ ) and 323-U1341B-37H-CC (325.83335.28 mbsf). The LO datum of silicoflagellate Distephanus jimlingii was found in Samples 323-U1341A38H-CC (332.71-342.26 mbsf) and 323-U1341B$38 \mathrm{H}-\mathrm{CC}$ (335.18-345.78 mbsf). In both holes, these datum events fit the age-depth profiles established by other biostratigraphic results and paleogeomagnetic polarity events (Table T2; Fig. F12). Silicoflagellate and ebridian zones were assigned based on these datums, with the exception of the upper part of both holes, as listed in the abundance tables.

Silicoflagellate assemblages are composed mainly of Distephanus speculum, Distephanus medianoctisol, and D. octonarius in most core catcher samples from both holes. However, their dominance is not constant throughout, which may suggest a paleoenvironmental change in surface waters.

\section{Radiolarians}

Radiolarian biostratigraphy is based on analysis of core catcher samples from Holes U1341A-U1341C. Radiolarian stratigraphy at Site U1341 extends from the Botryostrobus aquilonaris Zone (upper Quaternary) to the Dictyophimus bullatus Zone (middle Pliocene) in the subarctic Pacific (Kamikuri et al., 2007). In Sample 323-U1341B-71X-CC the LO of D. bullatus (3.8-4.0 Ma) was identified by the occurrence of several specimens. However, these specimens are not the typical form described by Morley and Nigrini (1995) and Motoyama (1996), although they are similar to Dictyophimus sp. B described by Motoyama (1996). We assigned this datum because Motoyama (1996) described the simultaneous occurrence of the LOs of both D. bullatus and Dictyophimus sp. B. Hence, we suggest that the age of the core bottom is between 3.8 and 4.0 Ma. Clearly, further shore-based work will be required to confirm the datum. As at Site U1340, the Stylatractus universus Zone (0.4-0.9 $\mathrm{Ma})$ is unclear because of very rare occurrences of $S$. universus. Nine radiolarian datums derived in the subarctic Pacific were identified at this site (Tables T2, T12). These datums are basically consistent with other biostratigraphic and paleomagnetic datums and indicate relatively high sedimentation rates (average $=15 \mathrm{~cm} / \mathrm{k} . \mathrm{y}$.). Among the radiolarian datums, the FOs of Eucyrtidium matuyamai in Holes U1341AU1341C significantly differ from paleomagnetic datums. Because the FO of this species in Hole U1340A (at another Bowers Ridge site) is consistent with paleomagnetic datums, the discrepancy at Site 
U1341 stems from missing the true FO for E. matuyamai due to its rare occurrence.

Radiolarian abundances and preservation are shown in Table T13. Radiolarian preservation is good to moderate in sediment samples from the uppermost $400 \mathrm{~m}$ at Site U1341 and moderate to poor in the section below $\sim 400$ mbsf. Below 400 mbsf, few radiolarian specimens occur, and some are broken or incomplete. Radiolarians are abundant to common in the uppermost $100 \mathrm{~m}$, but their abundance decreases in the interval below 100 mbsf in each hole.

Changes in the abundance of Cycladophora davisiana, a cold, well-ventilated intermediate water-dwelling and deepwater-dwelling species, show antiphase patterns with abundances of calcareous microfossils (calcareous nannofossils and planktonic foraminifers) in each hole at Site U1341. This abundance pattern suggests a relationship between intermediate water formation in the subarctic Pacific and carbonate preservation. Cycladophora sakaii is thought to be an ancestor species of C. davisiana (Motoyama, 1997). Occurrences of $C$. sakaii are very low at Site U1340 (water depth $=\sim 1300 \mathrm{~m}$ ). In contrast, $C$. sakaii is found constantly below $\sim 100 \mathrm{mbsf}$ at Site U1341 (water depth $=\sim 2200 \mathrm{~m}$ ), implying that $C$. sakaii dwelled mainly in deep water below $\sim 1000 \mathrm{~m}$.

\section{Palynology: dinoflagellate cysts, pollen, and other palynomorphs}

Forty-four core catcher samples from Holes U1341A and U1341B were analyzed for palynological content (Table T14). Five samples are barren with respect to dinoflagellate cysts, but they contain few to rare pollen and reworked palynomorphs. Palynomorphs are moderately to well preserved in the upper part of the sequence (the uppermost $300 \mathrm{~m}$ of Hole U1341A), whereas they are moderately to poorly preserved in the interval below 300 mbsf. Pollen grains and spores occur in most samples, with variable concentrations usually ranging between 0 and 400 grains/ $\mathrm{cm}^{3}$. Samples are dominated by tree pollen Pinus and Picea. Shrub and herb pollen and spores of pteridophytes (fern and moss) occur in low numbers, except in Samples 323-U1341A-3H-CC, 5H-CC, and $11 \mathrm{H}-$ CC, where they are relatively abundant. This variability reflects changing vegetation in adjacent lands. Phycoma of prasinophytes (freshwater algae) are present in very low concentrations in only a few samples (Table T14). Reworked pre-Neogene palynomorphs, which indicate detrital transport, occur generally in few numbers, except for Samples 323U1341A-5H-CC, 11H-CC, and 13H-CC and 323U1341B-45H-CC, where they are common. Organic linings of benthic foraminifers, which can be used as an index of calcium carbonate dissolution (de Vernal and Mudie, 1992), occur throughout the sequence and peak in abundance between 340 and $440 \mathrm{mbsf}$ and in Sample 323-U1341A-11H-CC. This peak suggests some calcium carbonate dissolution. However, shipboard palynological preparations and analyses were insufficient to accurately assess carbonate preservation.

With 21 taxa recorded, dinoflagellate cyst species diversity is slightly higher at Site U1341 than at Sites U1339 and U1340. Dinoflagellate cysts are common to very abundant in most samples from the uppermost $200 \mathrm{~m}$, whereas their concentration is usually $<400$ cysts $/ \mathrm{cm}^{3}$ below 200 mbsf. Note that the concentration of dinoflagellate cysts is extremely variable, ranging from $<100$ to $>10,000$ cysts $/ \mathrm{cm}^{3}$. Such amplitude of variation greater than two orders of magnitude suggests varying dinoflagellate productivity and sea-surface conditions through geologic time. An extremely high abundance of dinoflagellate cysts at 98.41 mbsf (Sample 323-U1341A-11H-CC) may well be coeval to an interglacial or interstadial interval.

In summary, dinoflagellate cyst assemblages are dominated by protoperidinial taxa commonly related to heterotrophic productivity. However, autotrophic taxa such as Bitectatodinium tepekiense and Nematosphaeropsis lemniscata/labyrinthus occur in many samples, mainly from the uppermost $300 \mathrm{~m}$, and dominate the assemblages in Samples 323U1341A-7H-CC and 15H-CC. Their dominance may be related to the incursion of oligotrophic, more oceanic water. The polar and subpolar taxa Islandinium minutum, Operculodinium centrocarpum-Arctic morphotype, and Impagidinium pallidum, which are known to be abundant in regions where sea ice cover occurs up to 12 months per year and winter sea-surface temperature is $<0^{\circ} \mathrm{C}$, occur only in the upper part of the sequence starting at $\sim 371$ mbsf (Table T14). Relatively warm water species such as Impagidinium aculeatum and Impagidinium patulum occur only sporadically. Below 300 mbsf the diversity decreases, and the assemblages are dominated by the protoperidinial Brigantedinium spp. and Trinovantedinium variabile or by the extinct species Filisphaera filifera. Trinovantedinium variabile appears below $300 \mathrm{~m}$ CCSF-A and dominates the assemblage of Sample 323-U1341A-60X-CC. In modern sediments, this species has been recorded in the northeastern Pacific margins, with very low percentages at latitudes south of $40^{\circ} \mathrm{N}$ (Radi and de Vernal, 2004). It has not been recorded in the modern North Atlantic and Arctic oceans, but it was reported to occur in Miocene and Pliocene sediments of the southern North Sea (e.g., Louwye et al., 2007). In Hole U1341A, Lejeunecysta 
falax was recorded for the first time in Pleistocene sediments (Sample 323-U1341A-15H-CC). This species was previously known to occur only in Pliocene and Miocene formations with poorly constrained biostratigraphic occurrence ranges (Bujak, 1984; de Vernal and Mudie, 1992). Finally, F. filifera indicates an age of 1.4-1.7 Ma in Sample 323-U1341A-23H-CC according to its LO in the North Pacific and North Atlantic (Bujak, 1984; M. Smelror et al., unpubl. data).

\section{Discussion}

Quantitative and semiquantitative data were collected for each microfossil group at Site U1341 (Fig. F13). Diatoms are the most abundant microfossil group throughout the cores. Heavily silicified diatoms are dominant in the lower interval below $\sim 400$ $\mathrm{m}$ CCSF-A and decline thereafter, suggesting that nutrients became less available, perhaps because of enhanced stratification after the onset of Northern Hemisphere Glaciation. Below 300 mbsf, dinoflagellate cyst diversity decreases and assemblages are dominated by heterotrophic protoperidinial taxa associated with diatom production. Sea ice diatoms increase above $400 \mathrm{~m}$ and again above $100 \mathrm{~m}$ CCSF-A, indicating increasing influence of sea ice over time. Polar dinoflagellate cysts, which are known to occur in regions with seasonal sea ice coverage of up to 12 months per year, occur significantly only in the uppermost $200 \mathrm{~m}$ of the sequence, confirming the presence of seasonal sea ice coverage. Calcareous foraminifers and nannofossils have the best preservation in the uppermost part of the section above $\sim 240 \mathrm{~m}$ CCSF-A, whereas in the lower part of the sequence their preservation has probably been affected by postdepositional processes such as diagenetic recrystallization. The best calcareous preservation broadly coincides with the highest abundances of sea ice diatoms, polar dinoflagellate cysts, and radiolarians living in cold, oxygen-rich intermediate water masses. Because the preservation of carbonate in deep-sea sediments is hindered by high productivity and associated low oxygen in the bottom waters, it appears that productivity may have been reduced by direct seasonal sea ice coverage and enhanced stratification above $240 \mathrm{~m}$ CCSF-A. Sea ice diatoms, intermediate water-dwelling radiolarians, and calcite preservation increase markedly at $\sim 110$ m CCSF-A.

Benthic foraminifer assemblages vary upsection, with the gradual replacement of M. communis Assemblage IV with E. bradyi Assemblage II between $\sim 430$ and $\sim 370 \mathrm{~m}$ CCSF-A ( 3-2.5 Ma) (Fig. F13). The ecological significance of these species is not well known, but the change in assemblage could reflect a decrease in oxygen levels after this time via a change in surface water productivity and/or deepwater circulation regime.

\section{Paleomagnetism}

The archive halves of all cores recovered at Site U1341 were measured on the three-axis cryogenic magnetometer. All measurements were done at 2.5 $\mathrm{cm}$ intervals for APC cores and $20 \mathrm{~cm}$ intervals for $\mathrm{XCB}$ cores. The natural remanent magnetization (NRM) was measured before (NRM step) and/or after (demagnetization step) stepwise alternating-field (AF) demagnetization in peak fields up to $20 \mathrm{mT}$. Cores 323-U1341A-1H through $12 \mathrm{H}$ and Sections $323-\mathrm{U} 1341 \mathrm{C}-5 \mathrm{H}-3$ through $11 \mathrm{H}-5$ were measured at NRM and $20 \mathrm{mT}$ demagnetization steps; other cores from Site U1341 were measured only at $20 \mathrm{mT}$ demagnetization step to keep up with core flow.

The inclination, declination, and intensity after 20 mT AF demagnetization from Holes U1341A, U1341B, and U1341C are plotted in Figures F15, F16, and F17, respectively. The inclinations average nearly $70^{\circ}$ over the entire depth range of the cores. The site axial dipole inclination is $\sim 72^{\circ}$. The inclinations show several distinct intervals of reversed inclinations interpreted to be polarity epochs.

The declinations, after correction with the FlexIt tool to orient the declination data with north, suggest that there are multiple polarity intervals in the uppermost 17 cores from Holes U1341A and U1341B. The FlexIt tool appears to show a declination change of $\sim 180^{\circ}$ at the Brunhes/Matuyama boundary in Hole U1341A, but it does not seem to identify older polarity changes (Jaramillo onset or termination) or the Brunhes/Matuyama boundary in Hole U1341B.

The inclinations were averaged by core and section to provide an initial guide to polarity zonation in Hole U1341B (Fig. F18). The Brunhes, Jaramillo, and Gauss normal polarity chrons are discernible. The age of each chron and preliminary defined depths are shown in Table T15. Examining directional data by core to better estimate actual polarity boundaries and comparing these data to polarity boundaries with paleontological age estimates indicate that the two data sets are generally consistent.

Although strong throughout all holes, NRM intensities noticeably decrease downhole relative to magnetic susceptibility (Figs. F15, F16, F17). There is a noticeable step in NRM and magnetic susceptibility intensity at $\sim 205 \mathrm{mbsf}$, and NRM and magnetic susceptibility values remain at the same level deeper in each hole. The presence of pyrite downcore clearly indicates that the sediments are undergoing sulfate reduction, which may be causing some limited mag- 
netic mineral dissolution that has caused the NRM intensity loss in Holes U1341A-U1341C. NRM and magnetic susceptibility intensities vary more than an order of magnitude on a meter scale, probably due mostly to variable flux of detrital sediment versus biogenic sediment (mostly diatoms at this site). The large changes in NRM intensity also appear to be associated with notable detrital (and presumably magnetic) grain size changes. Both of these variations make the use of relative paleointensity estimates as an indicator of field changes, which are determined by normalizing the cleaned NRM $(20 \mathrm{mT})$ by magnetic susceptibility, questionable in interpretation. Our paleointensity estimate from Hole U1341B is shown in Figure F19. The relative paleointensity variability is quite large, but most of it is strongly correlated with NRM and magnetic susceptibility variability. This is the same pattern noted at Site U1340.

As at other sites, there is no notable evidence for the presence of magnetic field excursions in the Brunhes Epoch (last 781,000 y). Sedimentation rates are sufficient that excursions should be obvious if they existed at this site, but enhanced bioturbation may be masking them. However, Brunhes-aged directional (inclination and declination) variability is replicable in Holes U1341A-U1341C and is interpreted to be real geomagnetic field secular variation. Its time frequency of variability is consistent with Site U1340 and other published records of secular variation; furthermore, it does not correlate to visible sediment variability.

Several good magnetic field polarity transitions are present in these cores. Figure F20 shows the Brunhes-Matuyama transition in Holes U1341A-U1341C. The same pattern of inclination variability is present in each hole, and there is also reproducible inclination variability just before the onset of the transition. Additionally, there are good polarity transition records for the Jaramillo onset and termination and perhaps for the Olduvai onset and Gauss termination as well.

Within the Matuyama reversed polarity interval, there is evidence for perhaps a dozen previously identified excursions. Future work will assess whether these excursions can be correlated between holes and with measurements from Hole U1340A. It is clear that there is still some overprint on the data, which prevents a clear picture of the excursions in each hole. However, the relative placement of these directional anomalies relative to paleointensity estimates in the various holes may permit us to tentatively identify them.

Some changes in microfossil assemblages appear to correlate with changes in clastic percentage in the sediment, which can be represented by magnetic susceptibility or relative paleointensity (Fig. F19) variations. Figure F19 shows the change in benthic foraminifer diversity with the relative paleointensity estimate, which appears to represent a strong environmental overprint. Low diversity occurs with low magnetic susceptibility or relative paleointensity values. This may indicate more reducing conditions near the sediment/water interface, which would be less favorable to benthic foraminifers.

\section{Geochemistry and microbiology Interstitial water chemistry}

Seventy-three interstitial water samples were extracted from $10 \mathrm{~cm}$ whole-round sediment sections from Holes U1341A and U1341B at a resolution of one sample per core for the first core, three samples per core in the second and third cores, two samples per core in the fourth core, and one sample per core thereafter. All samples from Hole U1341A were collected from APC cores (1.4-358 mbsf). Samples from Hole U1341B were collected from both APC cores (354-456 mbsf) and XCB cores (465.8-600 mbsf).

Aliquot samples were processed for routine shipboard analyses (see "Geochemistry" in the "Methods" chapter) and collected for shore-based analyses of sulfur and oxygen isotopes of sulfate and hydrogen sulfide, trace metals, dissolved organic carbon (DOC), and fatty acids.

\section{Alkalinity, dissolved inorganic carbon, $\mathrm{pH}$, chlorinity, and salinity}

Alkalinity increases from $3.6 \mathrm{mM}$ in the top of the sediment column to a maximum value of $11.9 \mathrm{mM}$ at $31 \mathrm{mbsf}$. Below this depth, alkalinity decreases to a minimum of $\sim 3.5 \mathrm{mM}$ at 600 mbsf. Between 31 and 358 mbsf, local maxima in alkalinity concentration occur at 183, 240, and 318 mbsf (Fig. F21C). The dissolved inorganic carbon (DIC) profile is similar to the alkalinity profile, with a maximum concentration of $12.4 \mathrm{mM}$ at $40 \mathrm{mbsf}$ (Fig. F21A). pH increases in the uppermost $15 \mathrm{~m}$ to 7.74. Below this depth, $\mathrm{pH}$ decreases and becomes fairly constant at 7.47 between 50 and 220 mbsf. Below 220 mbsf, pH increases to a local maximum of 7.61 at $240 \mathrm{mbsf}$ and then decreases to 7.2 at 600 mbsf (Fig. F21B). Salinity varies between 36 and 37 in the uppermost $200 \mathrm{~m}$ and is 36 down to 360 mbsf. Below this depth, salinity decreases to 34-35. Chloride concentrations slightly decrease with depth (Fig. F22C).

\section{Dissolved sulfate and hydrogen sulfide}

Dissolved sulfate concentrations decrease from seawater concentration at $1.4 \mathrm{mbsf}$ to $12 \mathrm{mM}$ at 450 
mbsf (Fig. F21D). The steepest sulfate concentration gradient is near the surface (1.4-24 mbsf). Between 300 and 400 mbsf, a second steep sulfate concentration gradient is present. Below 450 mbsf, sulfate concentrations slightly increase. Hydrogen sulfide concentrations in the uppermost $20 \mathrm{~m}$ range from 1 to 2 $\mu \mathrm{M}$. Below $20 \mathrm{mbsf}$, sulfide concentrations are consistently low, averaging $0.5 \mu \mathrm{M}$ (Fig. F21E).

\section{Dissolved ammonium, phosphate, and silica}

Ammonium concentrations at this site generally increase from $0.05 \mathrm{mM}$ at $1.4 \mathrm{mbsf}$ to $\sim 5 \mathrm{mM}$ at 600 mbsf (Fig. F21H). The slope of the ammonium profile, however, changes distinctly with depth, including zones of almost constant concentration at the top and bottom of the profile. The phosphate profile is similar to both the alkalinity and DIC profiles. Phosphate concentrations gradually increase throughout the uppermost $31 \mathrm{~m}$ from 19.1 to $50 \mu \mathrm{M}$. (Fig. F21G). Below $31 \mathrm{mbsf}$, phosphate concentrations decrease to $\sim 2 \mu \mathrm{M}$ at $600 \mathrm{mbsf}$. Dissolved silica concentrations increase from $140 \mu \mathrm{M}$ at 1.4 mbsf to $\sim 260 \mu \mathrm{M}$ at $270-360 \mathrm{mbsf}$.

\section{Dissolved calcium, magnesium, sodium, and potassium}

Dissolved calcium concentrations decrease from near-seawater values at the top to $<8 \mathrm{mM}$ between 200 and 300 mbsf (Fig. F22A). Calcium concentrations increase below 300 mbsf to maximum values of $\sim 14 \mathrm{mM}$. Magnesium concentrations gradually decrease from seawater concentration to a minimum at $\sim 500$ mbsf (Fig. F22B). Sodium and potassium concentrations are fairly constant throughout the sediment column (Fig. F22D, F22E).

\section{Dissolved manganese, iron, barium, boron, lithium, and strontium}

Barium, iron, and manganese concentrations are relatively low, with values close to or below detection limit, particularly in the deeper portion of the sediment column (Fig. F22G, F22H, F22L). Barium values below detection limit for the uppermost $\sim 350 \mathrm{~m}$ are not shown.

Interstitial water concentrations of lithium, boron, silica, and strontium increase with depth from seawater values to $\sim 60,1100,300$, and $130 \mu \mathrm{M}$, respectively (Fig. F22). There is a slight decrease in lithium in the uppermost $10 \mathrm{~m}$ (Fig. F22I), and boron concentrations decrease in the bottom 400-600 mbsf (Fig. F22J).

\section{Volatile hydrocarbons}

Headspace samples were taken adjacent to whole rounds. Methane was the only hydrocarbon gas detected with values of 2-4 ppmv (Fig. F21F).

\section{Sedimentary bulk geochemistry}

Seventy samples from Holes U1341A and U1341B were analyzed for solid-phase total carbon (TC), total nitrogen (TN), total sulfur (TS), and total inorganic carbon (TIC). From these analyses, total organic carbon (TOC) and calcium carbonate $\left(\mathrm{CaCO}_{3}\right)$ concentrations were calculated (see "Geochemistry" in the "Methods" chapter) (Fig. F23). $\mathrm{CaCO}_{3}$ concentrations at Site U1341 range from 0 to $29.4 \mathrm{wt} \%$ (average $=1.6 \mathrm{wt} \%)$ (Fig. F23A). Three maxima in $\mathrm{CaCO}_{3}$ concentrations in the uppermost $80 \mathrm{~m}$ and one local maximum at 514.8 mbsf were observed. These maximum values correlate well with increased abundance of calcareous nannofossils (see "Biostratigraphy"). TOC and TN contents range from 0.22 to $1.51 \mathrm{wt} \%$ (average $=0.51 \mathrm{wt} \%$ ) and from 0.05 to $0.17 \mathrm{wt} \%$ (average $=0.08 \mathrm{wt} \%$ ), respectively (Fig. F23B, F23C). TS contents range from 0.19 to $1.79 \mathrm{wt} \%$ (average = $0.61 \mathrm{wt} \%$ ) (Fig. F23D). Splits of squeeze cakes were also collected and treated for shore-based analyses of bulk elemental composition, iron mineral phases, and iron-monosulfide and pyrite content and sulfur isotopic composition.

\section{Microbiology}

Samples for total prokaryotic cell abundance were collected adjacent to interstitial water whole rounds at the resolution described above. Samples were fixed according to the protocol described in "Microbiology" in the "Methods" chapter.

\section{Conclusion}

Low methane concentrations, deep sulfate penetration, and low concentrations of DIC, alkalinity, ammonium, and phosphate suggest lower present-day microbial activity at this site than at sites located on the shelf (i.e., IODP Sites U1339, U1343, U1344, and U1345). Organoclastic sulfate reduction is the major metabolic pathway at Site U1341 and is likely most significant in the uppermost $30 \mathrm{~m}$ based on the DIC, alkalinity, and sulfate profiles.

The DIC, alkalinity, and phosphate profiles suggest that these constituents are not in steady state and/or that they are produced in the uppermost $\sim 30 \mathrm{~m}$ and are consumed in deeper sediment. The inconsistency between the ammonium, DIC, and phosphate pro- 
files indicates that nonsteady state cannot be the sole mechanism affecting these profiles. Most likely, DIC, alkalinity, and phosphate are produced in the uppermost $\sim 30 \mathrm{~m}$ by organic matter degradation. The formation of carbonates and iron phosphates in layers below $\sim 30$ mbsf could be responsible for the decrease in DIC, alkalinity, and phosphate.

The sulfate profile suggests a curiously high net consumption between 300 and 400 mbsf, despite the lack of methane and presumably the presence of only refractory organic carbon. Further studies and modeling are needed to explain this pattern. Furthermore, an increase in sulfate concentration is observed in the deepest part of the profile, which could indicate intrusion of seawater through, for example, channelized fluid flow in the crust. Similar patterns in the sulfate profile have been observed for Ocean Drilling Program (ODP) Leg 201 Sites 1225 and 1226 and have been attributed to water flow through the underlying basalts ( $\mathrm{D}^{\prime}$ Hondt, Jørgensen, Miller, et al., 2003).

\section{Physical properties}

Site U1341 was spudded at a water depth of $2193 \mathrm{~m}$ on the broad bathymetric terrace that rings the westfacing inside curve of Bowers Ridge. Seismic reflection data imply that the drilled section is a blanket of pelagic sediment draped over undulating basement relief. Cores recovered from Holes U1341AU1341C were sectioned on the catwalk and placed on the Special Task Multisensor Logger (STMSL) "fast track" to record whole-round magnetic susceptibility and GRA bulk density readings. Core sections were then allowed to warm to ambient core laboratory temperature $(\sim 4 \mathrm{~h})$ before being placed on the Whole-Round Multisensor Logger (WRMSL) for GRA, magnetic susceptibility, and $P$-wave scanning. Noncontact resistivity was not recorded with the WRMSL, and $P$-wave velocity and sediment shear strength were not measured on working-half sections.

Physical properties measured on cores recovered from Hole U1341B are described below with respect to the principal lithologic units (see "Lithostratigraphy" and "Stratigraphic correlation"). Core recovery was virtually continuous to a bottom-hole depth of $~ 605$ mbsf. Examination of the recovered cores identified two dominant lithologic units over which physical properties were measured. The major lithologic divisions shown in the figures accompanying this chapter are Unit I (diatom silt; surface to $\sim 203$ mbsf) and Unit II (nannofossil, sponge spicule-rich diatom ooze; 203 to $605 \mathrm{mbsf}$ ).

\section{GRA wet bulk density}

The WRMSL GRA sensor recorded a trend of slightly decreasing values of wet bulk density from a nearsurface reading of $\sim 1.4 \mathrm{~g} / \mathrm{cm}^{3}$ to $\sim 1.32 \mathrm{~g} / \mathrm{cm}^{3}$ at the bottom of Hole U1341B at $\sim 605$ mbsf. At $\sim 220$ mbsf, which is below the transition from Unit I to Unit II, a discernible but small shift to lower density near $\sim 1.25 \mathrm{~g} / \mathrm{cm}^{3}$ is evident (Fig. F24B). This shift is more prominently revealed in the downhole distribution of moisture and density (MAD) discrete sample bulk density values discussed below and shown in Figure F24A. The entire vertical profile of bulk density undulates broadly from an average of $\sim 1.30 \mathrm{~g} / \mathrm{cm}^{3}$ to a maximum of $\sim 1.45 \mathrm{~g} / \mathrm{cm}^{3}$. The wavelength of fluctuations narrows downhole. Oscillations from low to high values presumably reflect changing relative concentrations of terrigenous or siliciclastic detritus and siliceous microfossils.

The small overall downhole decrease in average bulk density likely reflects an increase in low-density siliceous microfossils, in particular diatom frustules, which counteract the density-increasing effects of compaction.

\section{Magnetic susceptibility}

The uppermost $\sim 210 \mathrm{~m}$ of sediment recovered from Hole U1341B exhibits rapid excursions to readings of >200-400 SI units (Fig. F25). Below this depth, magnetic susceptibility readings are subdued and rapid deflections to $>100$ SI units are uncommon except for a broad band of high susceptibility that occurs between 565 and 575 mbsf. The rapidly varying high values of the upper section are coincident with lithologic Unit I. Although ash layers occur in this unit, they are equally if not more abundant in underlying Unit II, which displays only background variations in readings. The contrast in the profiles of magnetic susceptibility readings between Units I and II perhaps reflects the diagenetic degradation of magnetic susceptibility properties.

\section{Natural gamma radiation}

Figure F26 records downhole NGR readings, which spike to highs of $>40$ counts/s above an undulating and generally decreasing trend from a near-surface average of $\sim 15$ counts/s to less than $\sim 5$ counts/s at the bottom of Hole U1341B. A shift to lower values occurs near the Unit I/II boundary at 203 mbsf (Fig. F26). The overall decreasing trend and broad superimposed oscillations suggest that clay mineral content decreases irregularly downhole, which is consistent with the decreasing terrigenous content of the drilled section, from the diatom silt of Unit I to the 
dominantly siliceous ooze of Unit II. Within this unit, a broad swing to higher readings above $\sim 25$ counts/s occurs between $\sim 380$ and 400 mbsf, presumably recording higher siliciclastic content (see "Stratigraphic correlation").

\section{$\boldsymbol{P}$-wave velocity}

WRMSL $P$-wave velocity increases downhole from $\sim 1.51 \mathrm{~km} / \mathrm{s}$ for near-surface sediment to $\sim 1.56 \mathrm{~km} / \mathrm{s}$ at the bottom of the hole at 605 mbsf (Fig. F27). The spacing of velocity measurements was changed from $30 \mathrm{~cm}$ in the uppermost $180 \mathrm{~m}$ of Hole U1341B to 5 $\mathrm{cm}$ between $\sim 180$ and 260 mbsf and $15 \mathrm{~cm}$ below $260 \mathrm{mbsf}$ to the bottom of the hole at $\sim 605 \mathrm{mbsf}$. A slight shift to lower readings $(0.02 \mathrm{~km} / \mathrm{s})$ appears to occur across the transition from lithologic Unit I to Unit II. The low overall gradient in downhole velocity, which is estimated at only $0.008 \mathrm{~km} / \mathrm{s} / 100 \mathrm{~m}$, is a manifestation of the ability of diatomaceous sediment to resist compaction (see "MAD porosity and water content" below).

\section{MAD (discrete sample) wet bulk density}

To measure physical properties with the MAD technique, sediment samples of $\sim 10 \mathrm{~cm}^{3}$ were routinely collected from Sections 1, 3, and 5 of each core recovered from Hole U1341B. Wet sediment bulk density, one of the principal physical properties measured, can be compared with GRA wet bulk density readings recorded with the STMSL and WRMSL scanning systems.

Figure F24A presents the downhole distribution of MAD bulk density, which can be compared with the GRA bulk density profile in Figure F24B. MAD density plotted at a higher exaggeration clearly reveals the contrasting density characteristics of the diatom silt of lithologic Unit I and the siliceous microfossil ooze of Unit II. Unit I sediment density fluctuates between 1.62 and $1.2 \mathrm{~g} / \mathrm{cm}^{3}$ in a slight but perceptible increase with depth to the Unit I/II boundary. Density decreases at this boundary to $\sim 1.27 \mathrm{~g} / \mathrm{cm}^{3}$, a value effectively the same as that recorded by the WRMSL GRA scanner (Fig. F24B). Density in Unit II varies less than in Unit I and increases to a slightly higher average of $\sim 1.36 \mathrm{~g} / \mathrm{cm}^{3}$ at $\sim 380 \mathrm{mbsf}$. Below this depth, bulk density decreases slightly and irregularly to the bottom of Hole U1341B. The lower overall bulk density in Unit II apparently reflects a higher concentration of low-density siliceous microfossils than that found in the diatom silt of overlying Unit I.

\section{MAD porosity and water content}

Just beneath the surface, porosity values average $\sim 80 \%$, with a corresponding water content of $\sim 60 \%$ (Fig. F28; Table T16). At the bottom of Hole U1341B, water content decreases slightly to $\sim 56 \%$ and porosity correspondingly decreases to $\sim 75 \%$. Similar to the depth profiles of most other physical properties, the downhole distribution of sediment porosity exhibits undulations or excursions to higher and lower values. These oscillations are more pronounced within the diatom silt beds of lithologic Unit I than they are within the siliceous ooze of underlying Unit II. Across the transition from Unit I to Unit II, a prominent break to higher readings is evident in both the water content and porosity profiles. This change reflects the high porosity of diatom ooze and its resistance to compaction-driven consolidation and densification, as demonstrated by the overall downhole decrease in bulk density (Fig. F24).

\section{Grain density}

The downhole variation in grain density is prominently offset, from an average density of $\sim 2.39 \mathrm{~g} / \mathrm{cm}^{3}$ to $2.23 \mathrm{~g} / \mathrm{cm}^{3}$ at the Unit I/II boundary (Fig. F29; Table T16). Average density also decreases with depth from a near-surface value of $\sim 2.50 \mathrm{~g} / \mathrm{cm}^{3}$ to a low of $2.10 \mathrm{~g} / \mathrm{cm}^{3}$ at the bottom of Hole U1341B. These trends are interpreted as tracking the downhole increase in the relative abundance of low-density siliceous microfossils, particularly diatoms. Superimposed on this overall gradient are excursions to higher and lower readings similar to those exhibited by the profiles of porosity and water content (Fig. F28), wet bulk density (Fig. F24), and NGR (Fig. F26).

\section{Thermal conductivity}

Thermal conductivity measurements were typically made on Section 3 of each core recovered from Hole U1341B. Thermal conductivity decreases overall with depth from a near-surface value of $0.85 \mathrm{~W} /(\mathrm{m} \cdot \mathrm{K})$ to 0.80 $\mathrm{W} /(\mathrm{m} \cdot \mathrm{K})$ at the bottom of Hole U1341B (Fig. F30). This profile thus parallels the downhole decreasing values of most other physical properties measured on cores recovered from Hole U1341B. A break or change in the thermal conductivity profile is not obvious at the 203 mbsf Unit I/II boundary. However, with respect to the density of measurement points of other MAD properties, thermal conductivity determinations are more widely spaced and are least capable of tracking a change in thermal conductivity at the boundary. As was conjectured for sediment re- 
covered at Sites U1339 and U1340, the decrease in thermal conductivity readings with depth is ascribed to the increased abundance of siliceous microfossils, which also lowers the readings of NGR, porosity, water content, bulk density, and grain density (Figs. F24, F26, F28, F29).

\section{Stratigraphic correlation}

The composite depth scale and splice at Site U1341 was constructed from 0.0 to $374.40 \mathrm{~m}$ CCSF-A (as defined in "Stratigraphic correlation" in the "Methods" chapter). The splice consists of one continuous splice from the mudline to $141.32 \mathrm{~m}$ CCSF-A and two appended "floating" splices from 141.3 to $326.43 \mathrm{~m}$ CCSF-A and from 326.44 to $374.40 \mathrm{~m}$ CCSF-A.

The continuous splice ranges from the top of Core 323-U1341A-1H to interval 323-U1341B-14H-7, 88 $\mathrm{cm}$ (Tables T17, T18). The first floating splice ranges from interval $323-\mathrm{U} 1341 \mathrm{~B}-15 \mathrm{H}-1,0 \mathrm{~cm}$, to $323-$ U1341A-34H-7, $64 \mathrm{~cm}$. The second floating splice ranges from interval $323-\mathrm{U} 1341 \mathrm{~A}-35 \mathrm{H}-1,0 \mathrm{~cm}$, to the base of Section 323-U1341B-39H-7. These appended intervals are supported by wireline logging data compared to core logging of NGR (see "Downhole measurements"). Additional cores below the splice are included in the composite depth framework by appending them with a constant affine value specific to each hole.

Correlations were accomplished using IODP Correlator software (version 1.655, which was replaced by version 1.656 during site operations), and some intervals were checked with digital line-scan images with Correlyzer (version 1.3.2, which was replaced by version 1.3.3 during site operations).

The composite (CCSF-A) and splice (CCSF-D) depth scales are based primarily on the stratigraphic correlation of WRMSL magnetic susceptibility data (Fig. F31), augmented with STMSL GRA bulk density data (Fig. F32) and whole-round NGR data (Fig. F33). $P$ wave velocity data were also collected for part of the cores but are not illustrated here.

The CCSF-A and CCSF-D scales were constructed by assuming that the uppermost sediment (the mudline) in Core 323-U1341A-1H was the sediment/water interface. A mudline was also recovered in Cores 323-U1341B-1H, 323-U1341C-1H, and 323-U1341D$1 \mathrm{H}$, confirming the fidelity of the top of the recovered section. Core 323-U1341A-1H serves as the anchor in the composite depth scale and is the only core with depths that are the same on the mbsf, CCSF-A, and CCSF-D scales. From this anchor the splice was built downhole, correlating the variations in core logging data on a core-by-core basis using Correlator.

At two depth horizons there was no clear correlation between holes, and it appeared that the gaps between cores in all holes were aligned here. In the first horizon, the top of Section 323-U1341B-15H-1 (132.58 mbsf; $141.32 \mathrm{~m}$ CCSF-A) is appended below the bottom of Section 323-U1341B-14H-7 (132.2 mbsf; 140.97 m CCSF-A). In the second horizon, the top of Section 323-U1341A-35H-1 (309.20 mbsf; $326.43 \mathrm{~m}$ CCSF-A) is appended below the bottom of Section 323-U1341A-34H-7 (309.34 mbsf; $326.43 \mathrm{~m}$ CCSF-A).

In addition to these appended intervals, the splice includes several suspect tie points where overlap between holes was short or uncertain: the tie point at $35.91 \mathrm{~m}$ CCSF-A from interval 323-U1341C-4H-7, $78.15 \mathrm{~cm}$ (34.28 mbsf), to $323-\mathrm{U} 1341 \mathrm{~A}-5 \mathrm{H}-2,99.5$ $\mathrm{cm}$ (33.99 mbsf), is uncertain because it occurs within an interval of sediment deformation. We selected Core 323-U1341A-5H for this interval of the splice because it was visually less deformed than cores at equivalent CCSF-A depths in other holes and its base provided good overlap with Core 323U1341B-5H. The tie points at $48.81 \mathrm{~m}$ CCSF-A between interval 323-U1341B-5H-7, $18.10 \mathrm{~cm}$ (46.38 mbsf), and 323-U1341C-6H-1, $140.2 \mathrm{~cm}$ (44.9 mbsf), and at $122.69 \mathrm{~m}$ CCSF-A between interval 323U1341C-13H-7, $20.4 \mathrm{~cm}$ (114.20 mbsf), and 323U1341A-14H-2, $65.76 \mathrm{~cm}$ (119.16 mbsf), is uncertain for similar reasons. All splice tie points at composite depths below $224 \mathrm{~m}$ CCSF-A are tentative because the amplitude of variation in magnetic susceptibility is very low in this interval. The section below 246.87 $m$ CCSF-A (at the bottom of Hole U1341C) was only cored in Holes U1341A and U1341B, and the lack of a third hole made it impossible to check the affine values or splice tie points. In these intervals the splice is based on NGR data rather than magnetic susceptibility data.

Although several weak points were identified in the development of composite depths and a splice at Site U1341 and this model should be tested with more detailed shore-based data, the spliced section in these intervals is supported by comparison of NGR core logging data (Fig. F34) with wireline logging data (see "Downhole measurements").

Within the splice, the composite CCSF-A depth scale is defined as the CCSF-D depth scale. Note that CCSF-D rigorously applies only to the spliced interval. Intervals outside the splice, although available with CCSF-A composite depth assignments, should not be expected to correlate precisely with fine-scale details within the splice or with other holes because of normal variation in the relative spacing of features 
in different holes. Such apparent depth differences may reflect coring artifacts or fine-scale variations in sediment accumulation and preservation at and below the seafloor.

The cumulative offset between mbsf and CCSF-A depth scales is approximately linear (Fig. F35). The affine growth factor (a measure of the fractional stretching of the composite section relative to the drilled interval; see "Stratigraphic correlation" in the "Methods" chapter) at Site U1341 is 1.06 between 0 and 374.4 mbsf. A few significant anomalies around this relatively uniform affine growth relationship are too large to be caused by ship heave and are unexplained. Calculation of MARs based on the CCSF-A or CCSF-D scales should account for this affine growth factor by dividing apparent depth intervals by the appropriate growth factor. After it is divided by the growth factor (accounting for the different depth intervals), this scaled depth scale should be referred to as CCSF-B.

Cores deeper than the spliced interval (i.e., Cores 323-U1341A-41H and 323-U1341B-40H through $71 \mathrm{X})$ are not tied to the splice but are appended with a constant affine value of $19.95 \mathrm{~m}$. MARs in this interval should not be divided by the affine growth factor because their depths are a linear transformation of drilling depths.

Although Hole U1341B was used for wireline logging, we were unable to provide detailed integration of the core data with the wireline logs because of software errors.

\section{Downhole measurements}

\section{Logging operations}

Downhole logging of Hole U1341B started after APC/XCB coring to a total depth of $600 \mathrm{~m}$ DSF (2750 $\mathrm{m}$ DRF) and ended on 31 July 2009 at $1520 \mathrm{~h}$ (all times are ship local time, UTC $-11 \mathrm{~h}$ ). In preparation for logging, the hole was conditioned with a 200 bbl sweep of sea gel (attapulgite, $\sim 9 \mathrm{ppg}$ ) and the bit was raised to the logging depth of 79 m DSF (2229 m DRF).

Two tool strings were deployed in Hole U1341B: the triple combo and the FMS-sonic combination (for tool and measurement acronyms, see "Downhole measurements" in the "Methods" chapter). Assembly of the triple combo started at $1930 \mathrm{~h}$ and the string was run in hole (RIH) at $2200 \mathrm{~h}$ after troubleshooting and replacing one of the tools. The tool string reached the bottom of the hole (total depth $=$ $2750 \mathrm{~m}$ wireline log depth below rig floor [WRF]), and a first uphole logging pass started at $0030 \mathrm{~h}$ on 1 August, at a speed of $900 \mathrm{ft} / \mathrm{h}$. After a short $(\sim 50 \mathrm{~m})$ repeat section was completed, the triple combo was sent back to total depth and the main pass started at $0100 \mathrm{~h}$. On its way up, the tool encountered significant drag in many places above $2650 \mathrm{~m}$ WSF, proceeding in a stick/slip motion that was detrimental to the quality of the data. As a result, the logging speed was increased to $1200 \mathrm{ft} / \mathrm{h}$ for most of the section logged, which seemed to reduce the sticking of the tool against the formation. The logging pass ended at $0315 \mathrm{~h}$ when the tool string crossed the seafloor, marked by a drop in natural radioactivity at $2150 \mathrm{~m}$ WRF. The triple combo reached the rig floor at $0500 \mathrm{~h}$ and was rigged down at $0600 \mathrm{~h}$.

Overall, the caliper of the density sonde showed a very irregular borehole, with many intervals having a hole diameter $>20$ inches. Although the quality of the FMS images was expected to be poor in some intervals, we decided that there was no risk for the tools and that the deployment of the FMS-sonic tool string would provide worthwhile velocity and image data. The tool string was built up and RIH at $0705 \mathrm{~h}$. It reached the bottom of the hole at $2748 \mathrm{~m}$ WRF at $0935 \mathrm{~h}$, and the first pass started at the logging speed of $900 \mathrm{ft} / \mathrm{h}$. The tool drag observed during the triple combo run also affected the FMS-sonic tool, and the logging speed was increased to $1200 \mathrm{ft} / \mathrm{h}$ for the rest of operations after the tool was configured to prevent any consequence to the vertical resolution of the data. The pass was completed at $1055 \mathrm{~h}$ with the bottom of the $35 \mathrm{~m}$ long tool string at $2275 \mathrm{~m} \mathrm{WRF}$. After the tool string returned to the bottom of the hole, the second pass started from total depth at $1125 \mathrm{~h}$ and ended at $1305 \mathrm{~h}$ after the last velocity measurements were recorded immediately below the bit. The tool string was at the surface at $1420 \mathrm{~h}$, and the rig floor was ready to begin operations in Hole $\mathrm{U} 1341 \mathrm{C}$ at $1530 \mathrm{~h}$.

\section{Downhole log data quality}

Figures F36 and F37 show a summary of the logging data acquired in Hole U1341B. These data were processed and converted to depth below seafloor and matched to depths between different logging runs. The resulting depth scale is wireline log matched depth below seafloor (WMSF; see "Downhole measurements" in the "Methods" chapter).

The first indicators of the overall quality of the logs are the size and shape of the borehole measured by the calipers. The hole size measured by the Hostile Environment Litho-Density Sonde (HLDS) caliper during the triple combo run and by the FMS arms is shown in the first column of Figures F36 and F37, respectively. Although both runs indicate an enlarged and irregular hole, the readings of the two orthogonal FMS calipers suggest that the borehole section 
was not circular and was probably highly elliptical. One caliper read $<10$ inches over most of the lower half of the interval logged, whereas the other caliper reading remained close to $\sim 14$ inches, near the limit of its range. The fact that the curves display variability over most of the hole suggests that both sets of arms were making some kind of contact with the formation, possibly with only one pad in some places. The readings of the larger HLDS caliper show that this single-arm caliper was likely following the longest "axis" of the hole and that the stronger and narrower arm was actually pushing inside the formation.

The large hole size mostly affected the measurements that require good contact with the formation, namely density and porosity. The very high neutron porosity values above $\sim 275 \mathrm{~m}$ WMSF indicate that porosity readings are invalid above this depth. Similarly, the anomalously low density values between 180 and $210 \mathrm{~m}$ WMSF are also indicative of bad tool contact and are not valid. Even if the FMS arms seem to have been in contact with the formation over most of the interval logged, this contact was likely only partial in places, resulting in blurry or featureless images in many intervals. It is still possible to identify many fine layers, mostly in the deeper part of the hole.

The quality of the logs can also be assessed by comparing the logs with the core measurements at the same site or by the repeatability of measurements acquired in different runs. Figure F36 shows a comparison of the gamma ray and density logs with the NGR and GRA track measurements on cores recovered from Hole U1341B and with MAD measurements made on samples from Site U1341. Except for the low density logging data between 180 and $210 \mathrm{~m}$ WMSF, all data sets are in good agreement, confirming that the logs are of generally good quality despite poor hole conditions. Comparison of the gamma ray logs measured during the main pass of the two runs in Figure F37 shows excellent repeatability between the two runs. All logs were referenced to the seafloor depth of $2150 \mathrm{~m}$ WRF identified during the main pass of the triple combo tool string.

The resistivity values measured by the electrode spherically focused resistivity (SFLU) measurement were lower than those recorded by induction measurements (e.g., medium induction phasor-processed resistivity [IMPH] and deep induction phasor-processed resistivity [IDPH] in Fig. F36), probably because of current loss at the electrodes and the eccentralization of the sonde. The higher induction resistivity values are more representative of the resistivity of the formation, but the higher resolution SFLU data are a good indication of the finer scale variability in the formation.

The display of the high coherence in sonic waveforms used to derive the compressional and shear velocities suggests that despite the enlarged hole and the closeness of the formation velocity to the sound velocity in the borehole fluid $(\sim 1500 \mathrm{~m} / \mathrm{s})$, the Dipole Sonic Imager (DSI) was able to capture distinct wave arrivals and measure reliable $V_{\mathrm{p}}$ and $V_{\mathrm{S}}$ profiles. Additional postcruise processing will be required to refine these profiles and will likely reduce the variability of $V_{\mathrm{P}}$ and $V_{\mathrm{S}}$ in some intervals.

\section{Logging stratigraphy and correlation}

The combined analysis of gamma ray, resistivity, density, and velocity logs allowed for the definition of several logging units characterized by specific trends. Variations in the sediment content of the three radioactive elements contributing to the natural radioactivity of the formation $(\mathrm{K}, \mathrm{U}$, Th; Fig. F38) were also used to define these units.

Logging Unit 1 (80-220 m WMSF) is characterized mainly by decreasing trends with depth in gamma radiation and resistivity, accompanied by several high peaks in these measurements. It coincides mostly with lithologic Unit I, which is composed of diatom ooze and diatom silt (see "Lithostratigraphy"). Figure F38 shows that most of the peaks in gamma radiation are related to high uranium content. The coincidence of these higher uranium values with higher resistivity and, to some extent, higher density is an indication that they are caused by authigenic carbonate, which was observed at many of these depths (Sections 323-U1341B-17H-2 and 17H-3; see Fig. F39A for a comparison with FMS images). One of the gamma ray peaks is associated with a prominent high in thorium at $135 \mathrm{~m}$ WMSF, which could be related to the ash layers observed at the same depth (Section 323-U1341B-15H-2; see "Lithostratigraphy").

Logging Unit 2 (220-350 mbsf) is defined by slightly increasing trends with depth in gamma radiation and density, whereas resistivity mostly decreases. The close similarity between the gamma ray and potassium profiles over this unit (Fig. F38) suggest enrichment in potassium-rich clay minerals with depth. Several peaks in gamma radiation can be observed in this unit as well, again generally due to higher uranium content and often associated with 
authigenic carbonate observed in the core (Sections 323-U1341B-32H-3 and 39H-4; see Fig. F39B for a comparison with FMS images)

The top of logging Unit 3 (350-425 m WMSF) is defined by a sharp drop in resistivity at $\sim 350 \mathrm{~m}$ WMSF and by similar changes in gamma radiation and density. Because $V_{\mathrm{p}}$ does not display any significant change at this depth, the change in density is likely responsible for the strong reflector that can be observed in seismic Line Stk5-1 at 3340 ms two-way traveltime (Sakamoto et al., 2005). This reflector can be reproduced, although with a lower amplitude, by a synthetic seismogram generated from density and $V_{\mathrm{P}}$ logs (Fig. F40). The wavelet used to produce the synthetic seismogram was extracted from the seafloor reflection identified from the traces adjacent to Shotpoint 670 and Site U1341 in Line Stk5-1. This logging unit is characterized by an increase in gamma radiation and resistivity with depth and generally by higher uranium content, as shown in Figure F38 by the consistent offset between total and computed gamma radiation. This can be associated with higher organic matter content, in agreement with higher TOC measured in this interval (see "Geochemistry and microbiology").

The top of logging Unit 4 (425-600 m WMSF) is defined by a drop in resistivity, which decreases with depth over the entire unit. The top of Unit 4 also coincides with an inflection in the overall increase with depth of shear velocity (Fig. F37) and, to a lesser extent, compressional velocity. Gamma ray values are generally lower than in the overlying logging unit, but they increase slightly with depth and again display several peaks due to higher uranium content associated with subtle resistivity peaks and the occurrence of authigenic carbonate (Cores 323$\mathrm{U} 1341 \mathrm{~B}-51 \mathrm{H}$ and $62 \mathrm{X}$ ). Some of the resistivity peaks in this unit, prominent in the FMS electrical images, can also be associated with dolostones (Section 323U1341B-58X-3; Fig. F39C).

\section{Temperature measurements}

The third-generation advanced piston corer temperature tool (APCT-3) was successfully deployed three times in Hole U1341A. The measured temperatures range from $4.68^{\circ} \mathrm{C}$ at $41.0 \mathrm{~m}$ DSF to $11.12^{\circ} \mathrm{C}$ at 136.0 $\mathrm{m}$ DSF and closely fit a linear geothermal gradient of $67.8^{\circ} \mathrm{C} / \mathrm{km}$ (Fig. F41). The temperature at the seafloor was $1.95^{\circ} \mathrm{C}$ based on the average of the measurements at the mudline during all APCT-3 deployments. A simple estimate of heat flow can be obtained from the product of the geothermal gradient by the average thermal conductivity $(0.825 \mathrm{~W} /[\mathrm{m} \cdot \mathrm{K}]$; see "Physical properties"), which gives a value of 55.9 $\mathrm{mW} / \mathrm{m}^{2}$, within the range of previous measurements in the area (the global heat flow database of the International Heat Flow Commission can be found at www.heatflow.und.edu/index.html).

Considering the variations in thermal conductivity with depth, a more accurate measure of heat flow in a conductive regime can be given by a "Bullard plot." The thermal resistance of an interval is calculated by integrating the inverse of thermal conductivity over depth. If the thermal regime is purely conductive, the heat flow will be the slope of the temperature versus thermal resistance profiles (Bullard, 1939). Thermal resistance calculated over the intervals overlying the APCT-3 measurements is shown in Table T19, and the resulting linear fit of the temperature gives a slightly higher heat flow value of $56.2 \mathrm{~mW} / \mathrm{m}^{2}$.

\section{References}

Alvarez Zarikian, C.A., Stepanova, A.Y., and Grützner, J., 2009. Glacial-interglacial variability in deep sea ostracod assemblage composition at IODP Site U1314 in the subpolar North Atlantic. Mar. Geol., 258(1-4):69-87. doi:10.1016/j.margeo.2008.11.009

Asahi, H., and Takahashi, K., 2007. A 9-year time-series of planktonic foraminifer fluxes and environmental change in the Bering Sea and the central subarctic Pacific Ocean, 1990-1999. Prog. Oceanogr., 72(4):343363. doi:10.1016/j.pocean.2006.03.021

Ayress, M.A., DeDeckker, P., and Coles, G.P., 2004. A taxonomic and distributional survey of marine benthic ostracoda off Kerguelen and Heard Islands, South Indian Ocean. J. Micropalaeontol., 23:15-38.

Barker, S., Archer, D., Booth, L., Elderfield, H., Henderiks, J., and Rickaby, R.E.M., 2006. Globally increased pelagic carbonate production during the mid-Brunhes dissolution interval and the $\mathrm{CO}_{2}$ paradox of MIS 11. Quat. Sci. Rev., 25(23-24):3278-3293. doi:10.1016/j.quascirev.2006.07.018

Barron, J.A., and Gladenkov, A.Y., 1995. Early Miocene to Pleistocene diatom stratigraphy of Leg 145. In Rea, D.K., Basov, I.A., Scholl, D.W., and Allan, J.F. (Eds.), Proc. ODP, Sci. Results, 145: College Station, TX (Ocean Drilling Program), 3-19. doi:10.2973/

odp.proc.sr.145.101.1995

Bé, A.W.H., and Tolderlund, D.S., 1971. Distribution and ecology of living planktonic foraminifera in surface waters of the Atlantic and Indian Oceans. In Funnel, B.M., and Riedel, W.R. (Eds.), The Micropaleontology of Oceans: Cambridge (Cambridge Univ. Press), 105-149.

Bubenshchikova, N., Nürnberg, D., Lembke-Jene, L., and Pavlova, G., 2008. Living benthic foraminifera of the Okhotsk Sea: faunal composition, standing stocks and microhabitats. Mar. Micropaleontol., 69(3-4):314-333. doi:10.1016/j.marmicro.2008.09.002

Bullard, E.C., 1939. Heat flow in South Africa. Proc. R. Soc. London, Ser. A, 173:474-502. 
Bujak, J.P., 1984. Cenozoic dinoflagellate cysts and acritarchs from the Bering Sea and northern North Pacific, DSDP Leg 19. Micropaleontology, 30(2):180-212. doi:10.2307/1485717

Butt, A., 1980. Biostratigraphic and paleoenvironmental analyses of the sediments at the Emperor Seamounts, DSDP Leg 55, Northwestern Pacific: Cenozoic foraminifers. In Jackson, E.D., Koizumi, I., et al., Init. Repts. DSDP, 55: Washington, DC (U.S. Govt. Printing Office), 289325. doi:10.2973/dsdp.proc.55.108.1980

Cronin, T.M., DeMartino, D.M., Dwyer, G.S., and Rodriguez-Lazaro, J., 1999. Deep-sea ostracode species diversity: response to late Quaternary climate change. Mar. Micropaleontol., 37(3-4): 231-249. doi:10.1016/S03778398(99)00026-2

de Vernal, A., and Mudie, P.J., 1992. Pliocene and Quaternary dinoflagellate cyst stratigraphy in Labrador Sea: paleoecological implications. In Head, M.J., and Wrenn, J.H. (Eds.), Neogene and Quaternary Dinoflagellate Cysts and Acritarchs: Salt Lake City (Publisher's Press), 329346.

D’Hondt, S.L., Jørgensen, B.B., Miller, D.J., et al., 2003. Proc. ODP, Init. Repts., 201: College Station, TX (Ocean Drilling Program). doi:10.2973/odp.proc.ir.201.2003

Didié, C., and Bauch, H.A., 2000. Species composition and glacial-interglacial variations in the ostracode fauna of the northeast Atlantic during the past 200,000 years. Mar. Micropaleontol., 40(1-2):105-129. doi:10.1016/ S0377-8398(00)00034-7

Didié, C., and Bauch, H.A., 2002. Implications of upper Quaternary stable isotope records of marine ostracodes and benthic foraminifers for paleoecological and paleoceanographical reconstructions. In Holmes, J.A., and Chivas, A.R. (Eds.), The Ostracoda: Applications in Quaternary Research: Washington, DC (Am. Geophys. Union), 279-299.

Flores, J.-A., Marino, M., Sierro, F.J., Hodell, D.A., and Charles, C.D., 2003. Calcareous plankton dissolution pattern and coccolithophore assemblages during the last 600 kyr at ODP Site 1089 (Cape Basin, South Atlantic): paleoceanographic implications. Palaeogeogr., Palaeoclimatol., Palaeoecol., 196(3-4):409-426. doi:10.1016/ S0031-0182(03)00467-X

Hine, N., 1990. Late Cenozoic calcareous nannoplankton from the northeast Atlantic [Ph.D. thesis]. Univ. East Anglia, Norwich, United Kingdom.

Husum, K., and Hald, M., 2004. Modern foraminiferal distribution in the subarctic Malangen Fjord and adjoining shelf, northern Norway. J. Foraminiferal Res., 34(1):3448. doi:10.2113/0340034

Kaiho, K., and Hasegawa, S., 1986. Bathymetric distribution of benthic foraminifera in bottom sediments off Onahama, Fukushima Prefecture, northeast Japan. In Matoba, Y., and Kato, M. (Eds.), Studies on Cenozoic Benthic Foraminifera: Akita (Akita Univ.), 43-52. (in Japanese)

Kamikuri, S., Nishi, H., and Motoyama, I., 2007. Effects of late Neogene climatic cooling on North Pacific radiolarian assemblages and oceanographic conditions. Palaeo- geogr., Palaeoclimatol., Palaeoecol., 249(3-4):370-392. doi:10.1016/j.palaeo.2007.02.008

Katsuki, K., and Takahashi, K., 2005. Diatoms as paleoenvironmental proxies for seasonal productivity, sea-ice and surface circulation in the Bering Sea during the late Quaternary. Deep-Sea Res., Part II, 52(16-18):2110-2130. doi:10.1016/j.dsr2.2005.07.001

Ling, H.Y., 1973. Silicoflagellates and ebridians from Leg 19. In Creager, J.S., Scholl, D.W., et al., Init. Repts. DSDP, 19: Washington (U.S. Govt. Printing Office), 751-775. doi:10.2973/dsdp.proc.19.127.1973

Ling, H.Y., 1992. Late Neogene silicoflagellates and ebridians from Leg 128, Sea of Japan. In Pisciotto, K.A., Ingle, J.C., Jr., von Breymann, M.T., and Barron, J., et al. (Eds.), Proc. ODP, Sci. Results, 127/128, Pt. 1: College Station, TX (Ocean Drilling Program), 237-248. doi:10.2973/ odp.proc.sr.127128-1.126.1992

Louwye, S., De Schepper, S., Laga, P., and Vandenberghe, N., 2007. The upper Miocene of the southern North Sea Basin (northern Belgium): a palaeoenvironmental and stratigraphical reconstruction using dinoflagellate cysts. Geol. Mag., 144(1):33-52. doi:10.1017/ S0016756806002627

Martini, E., 1971. Standard Tertiary and Quaternary calcareous nannoplankton zonation. In Farinacci, A. (Ed.), Proc. 2nd Int. Conf. Planktonic Microfossils Roma: Rome (Ed. Tecnosci.), 2:739-785.

Morley, J.J., and Nigrini, C., 1995. Miocene to Pleistocene radiolarian biostratigraphy of North Pacific Sites 881, 884, 885, 886, and 887. In Rea, D.K., Basov, I.A., Scholl, D.W., and Allan, J.F. (Eds.), Proc. ODP, Sci. Results, 145: College Station, TX (Ocean Drilling Program), 55-91. doi:10.2973/odp.proc.sr.145.107.1995

Motoyama, I., 1996. Late Neogene radiolarian biostratigraphy in the subarctic Northwest Pacific. Micropaleontology, 42(3):221-262. doi:10.2307/1485874

Motoyama, I., 1997. Origin and evolution of Cycladophora davisiana Ehrenberg (Radiolaria) in DSDP Site 192, northwest Pacific. Mar. Micropaleontol., 30(1-3):45-63. doi:10.1016/S0377-8398(96)00047-3

Radi, T., and de Vernal, A., 2004. Dinocyst distribution in surface sediments from the northeastern Pacific margin $\left(40-60^{\circ} \mathrm{N}\right)$ in relation to hydrographic conditions, productivity and upwelling. Rev. Palaeobot. Palynol., 128(12):169-193. doi:10.1016/S0034-6667(03)00118-0

Saito, T., Thompson, P.R., and Breger, D., 1981. Systematic Index of Recent and Pleistocene Planktonic Foraminifera: Tokyo (Univ. of Tokyo).

Sakamoto, T., Ikehara, M., Aoki, K., Iijima, K., Kimura, N., Nakatsuka, T., and Wakatsuchi, M., 2005. Ice-rafted debris (IRD)-based sea-ice expansion events during the past 100 kyrs in the Okhotsk Sea. Deep Sea Res., Part II, 52(16-18):2275-2301. doi:10.1016/j.dsr2.2005.08.007

Sato, T., Saito, T., Yuguchi, S., Nakagawa, H., Kameo, K., and Takayama, T., 2002. Late Pliocene calcareous nannofossil paleobiogeography of the Pacific Ocean: evidence for glaciation at 2.75 Ma. Rev. Mex. Cienc. Geol., 19(3):175-189.

Scholl, D.W., and Creager, J.S., 1973. Geologic synthesis of Leg 19 (DSDP) results; far North Pacific, and Aleutian 
Ridge, and Bering Sea. In Creager, J.S., Scholl, D.W., et al., Init. Repts. DSDP, 19: Washington, DC (U.S. Govt. Printing Office), 897-913. doi:10.2973/

dsdp.proc.19.137.1973

Stepanova, A.Y., 2006. Late Pleistocene-Holocene and recent Ostracoda of the Laptev Sea and their importance for paleoenvironmental reconstructions. Paleontol. J., 40(S2):91-204. doi:10.1134/ S0031030106080016

Takahashi, K., 2005. The Bering Sea and paleoceanography. Deep-Sea Res., Part II, 52(16-18):2080-2091. doi:10.1016/j.dsr2.2005.08.003

Takahashi, K., Fujitani, N., Yanada, M., and Maita, Y., 2000. Long-term biogenic particle fluxes in the Bering Sea and the central subarctic Pacific Ocean, 1990-1995. Deep-Sea Res., Part I, 47(9):1723-1759. doi:10.1016/S09670637(00)00002-9
Takahashi, K., Ravelo, A.C., and Alvarez Zarikian, C.A., 2009. Pliocene-Pleistocene paleoceanography and climate history of the Bering Sea. IODP Sci. Prosp., 323. doi:10.2204/iodp.sp.323.2009

Yanagisawa, Y., and Akiba, F., 1998. Refined Neogene diatom biostratigraphy for the northwest Pacific around Japan, with an introduction of code numbers for selected diatom biohorizons. Chishitsugaku Zasshi, 104:395-414.

Yasuhara, M., Cronin, T.M., and Martínez Arbizu, P., 2008. Abyssal ostracods from the south and equatorial Atlantic Ocean: biological and paleoceanographic implications. Deep-Sea Res., Part I, 55(4):490-497. doi:10.1016/ j.dsr.2008.01.004

Publication: 15 March 2011

MS 323-105 
Figure F1. Location map for Site U1341 on Bowers Ridge. DSDP = Deep Sea Drilling Project.

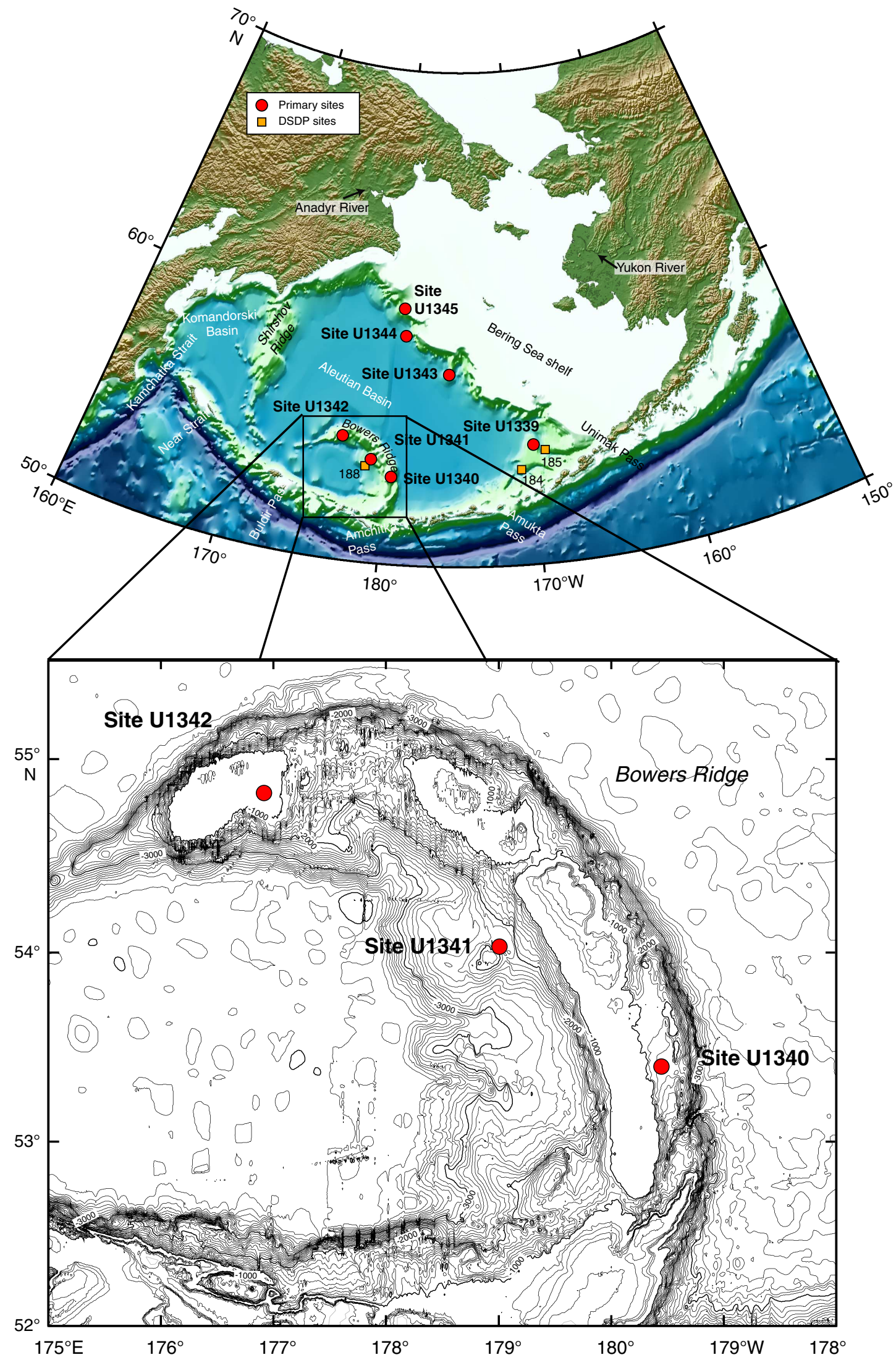


Figure F2. Seismic profile of Hakuhou-Maru Cruise KH99-3 Line Stk5-1 (west-east) near Site U1341.

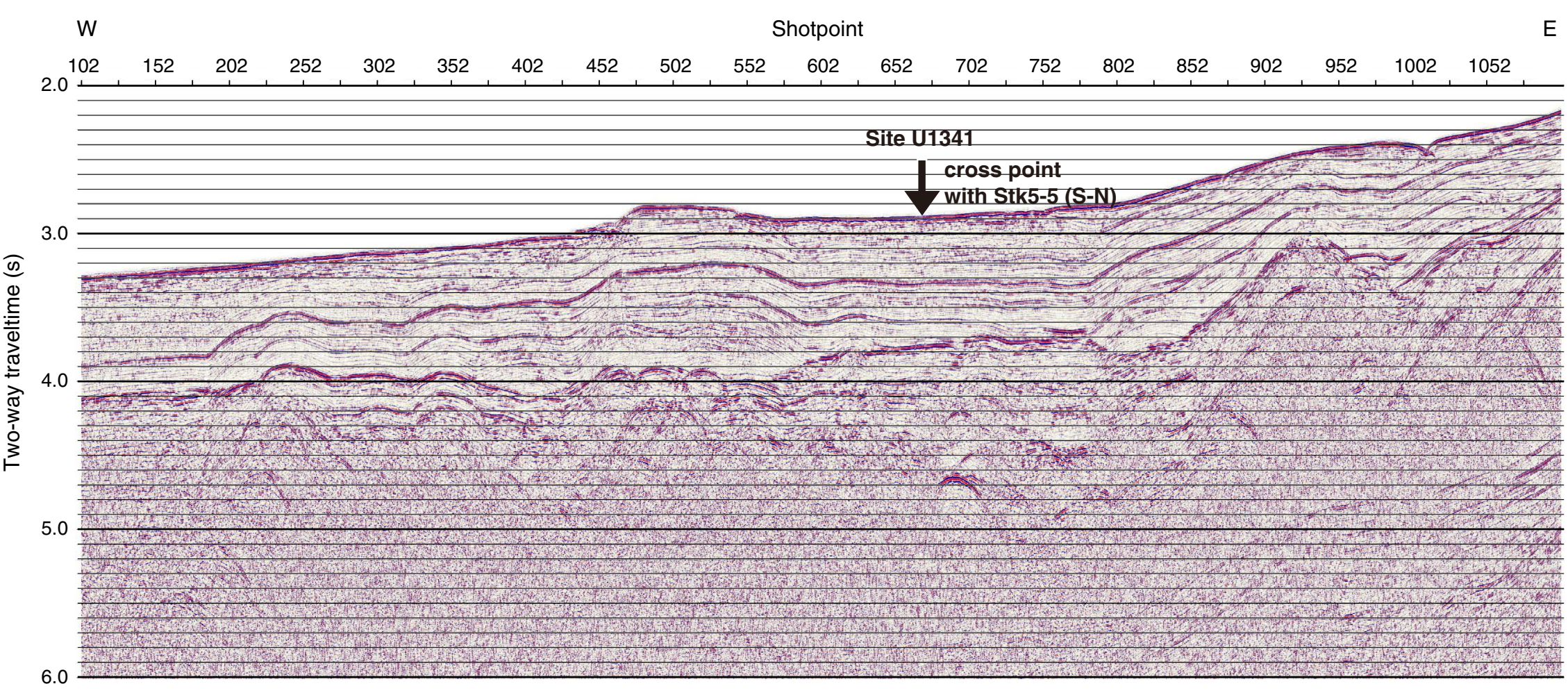

$E$

0 
Figure F3. Navigation map of Hakuhou-Maru Cruise KH99-3 around Site U1341 for close-up seismic profiles found in Figures F4 and F5.

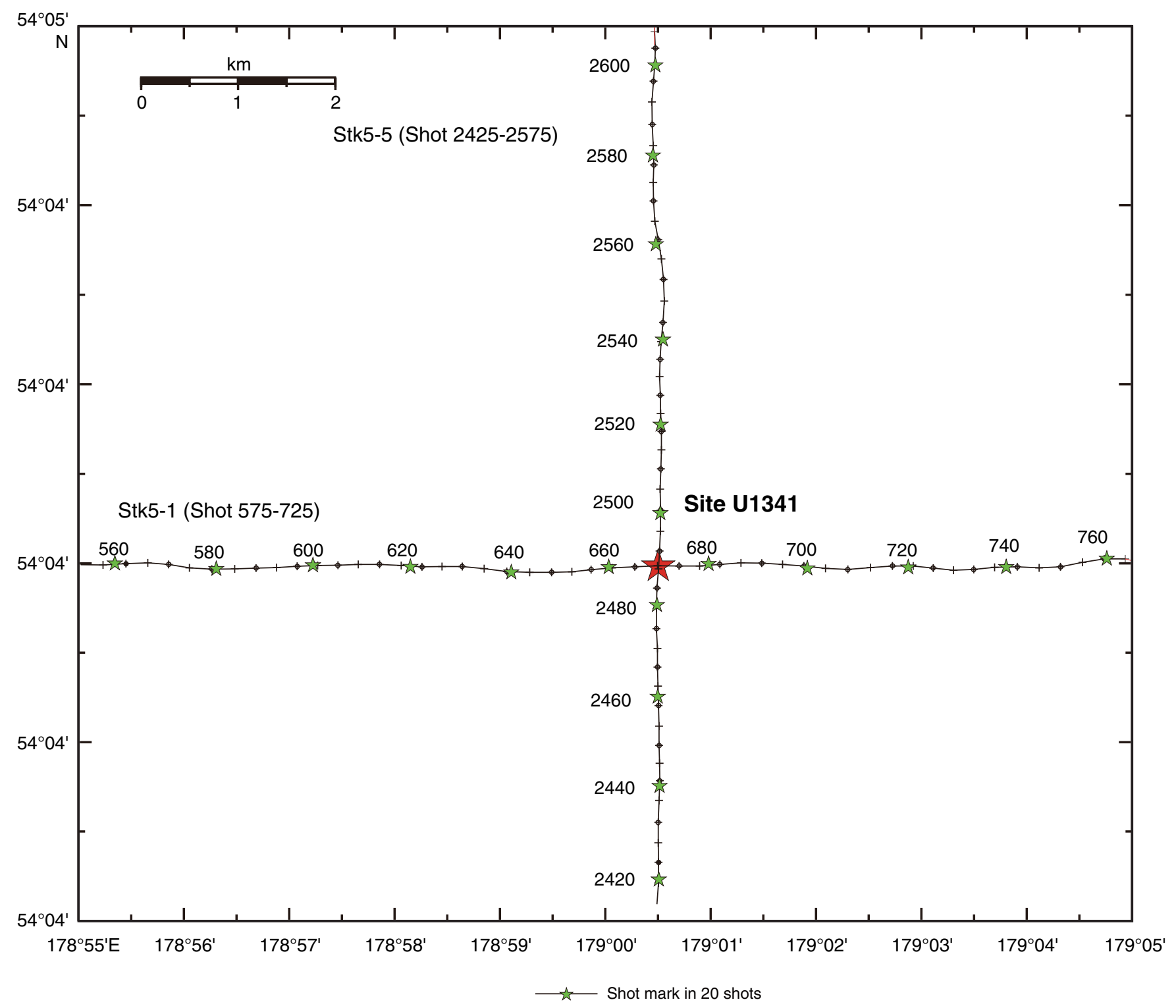


Figure F4. A. Close-up seismic profile of Hakuhou-Maru Cruise KH99-3 Line Stk5-1 (west-east) near Site U1341. Cross point with Line Stk5-5 (south-north) is at Shotpoint 670. B. Time-depth curve estimated from results of velocity analyses on Lines Stk5-1 and Stk5-5 around Site U1341.

A $w$

Shotpoint

E

$$
575
$$

595

615

635

655

675

695

715

3.0

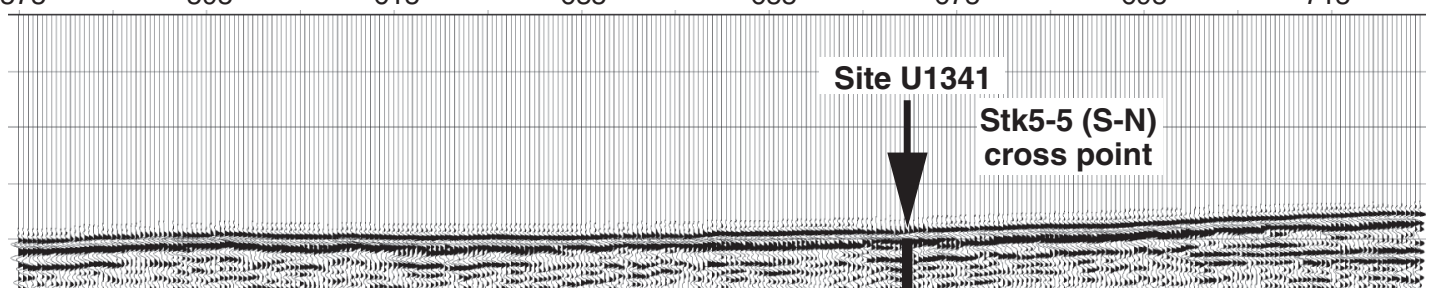

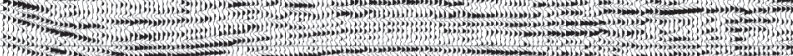

19.3.

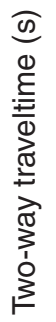

4.0

3.5

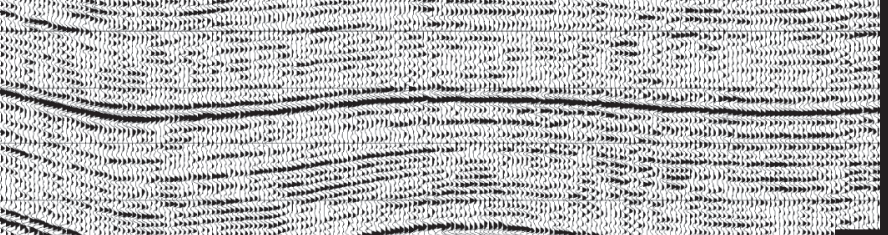

.

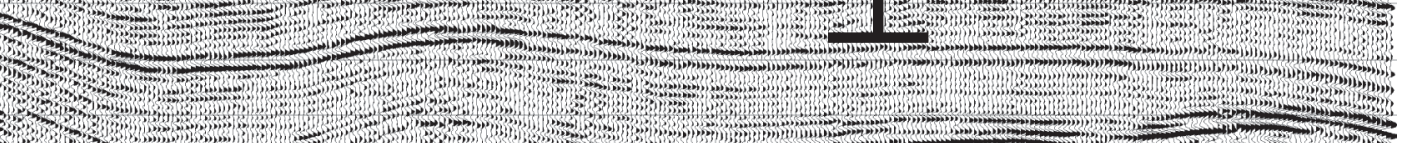

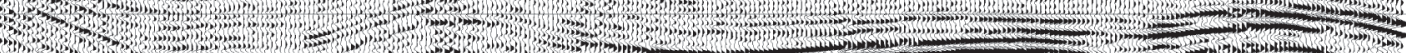

M.

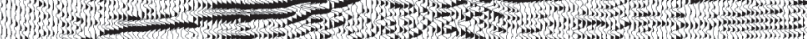

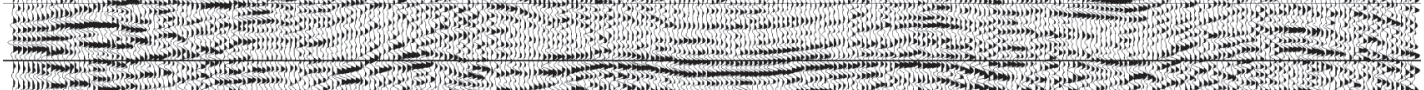

(n)

m.

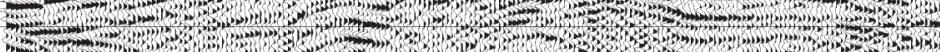

ro.

-

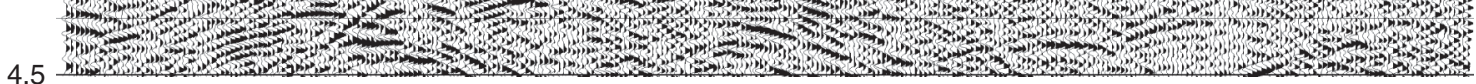

$\underset{0}{\stackrel{\mathrm{km}}{:}} \stackrel{0.5}{1}$

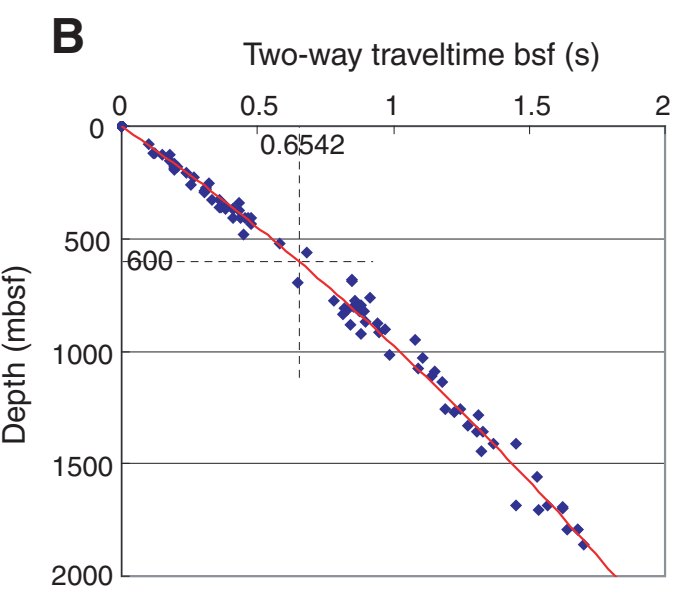


Figure F5. A. Close-up seismic profile of Hakuhou-Maru Cruise KH99-3 Line Stk5-5 (south-north) near Site U1341. Cross point with Line Stk5-1 (west-east) is at Shotpoint 2488. B. Time-depth curve estimated from results of velocity analyses on Lines Stk5-1 and Stk5-5 around Site U1341.

A s

2425
2445

2465

2485

Shotpoint

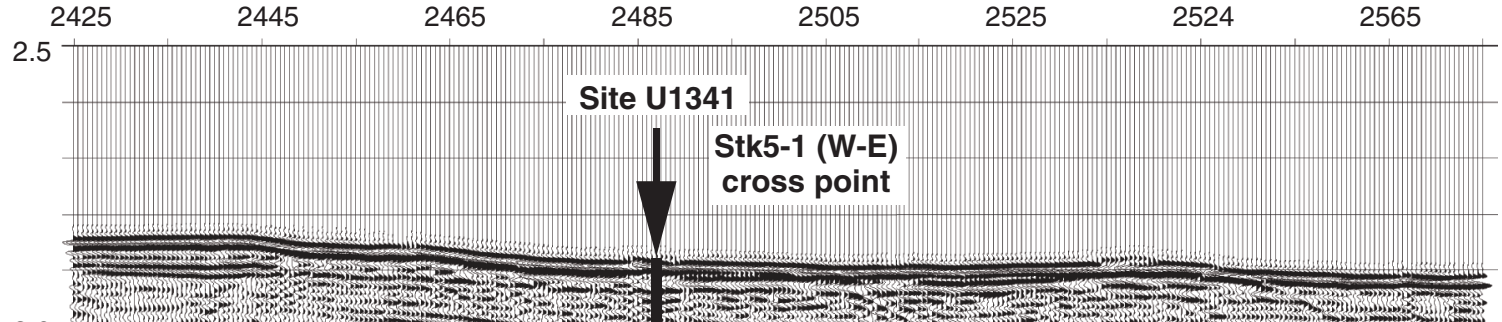

3.0

0
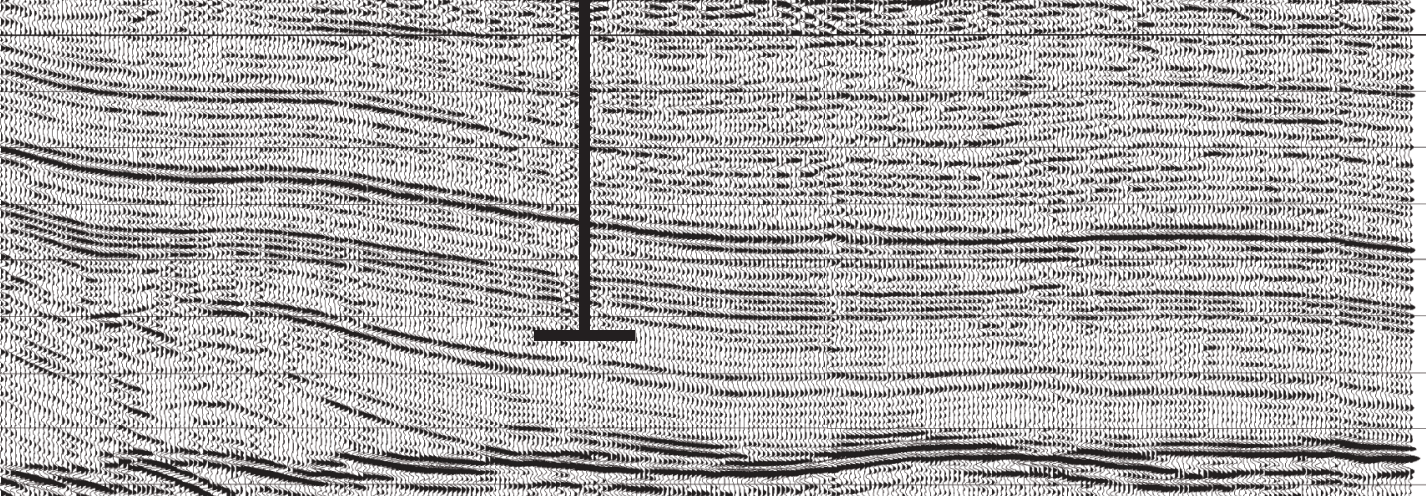

X

Y...

4.0

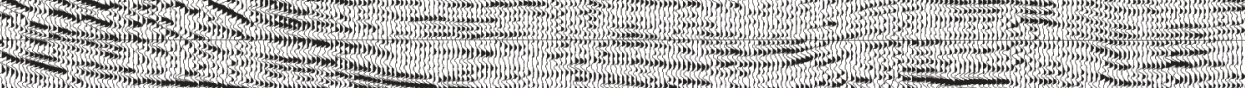

is.

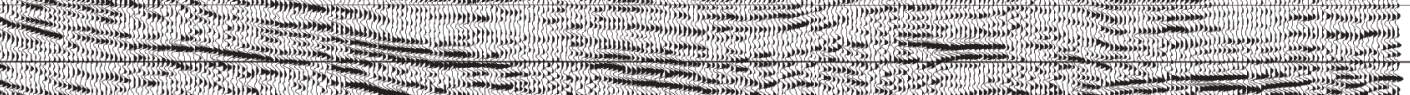

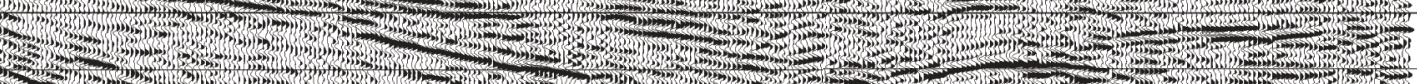

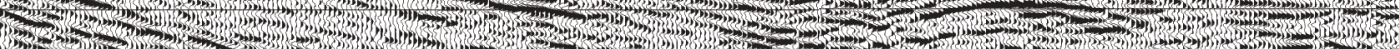

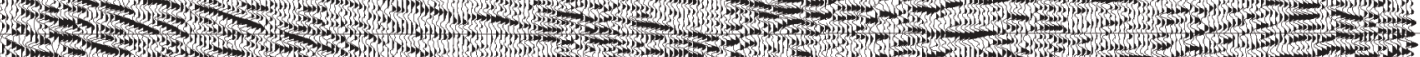<smiles>[SiH3]</smiles>

Fin.

,

4.5 3

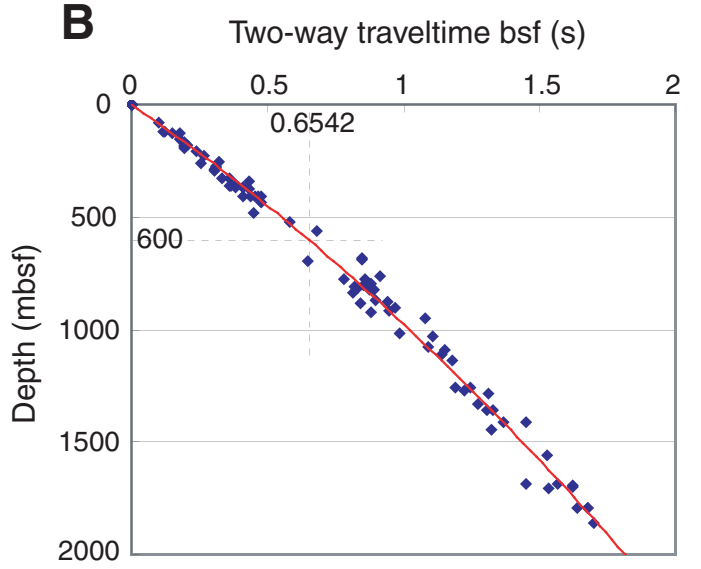


Figure F6. Summary of lithology, structures, accessories, microfossils, and physical properties, Hole U1341B. See legend in Figure F6 in the "Methods" chapter. Soft-sed = soft-sediment, auth = authigenic, calc $=$ calcareous, NGR = natural gamma radiation, GRA = gamma ray attenuation, sed rate $=$ sedimentation rate. A. $0-250$ mbsf. (Continued on next two pages.)

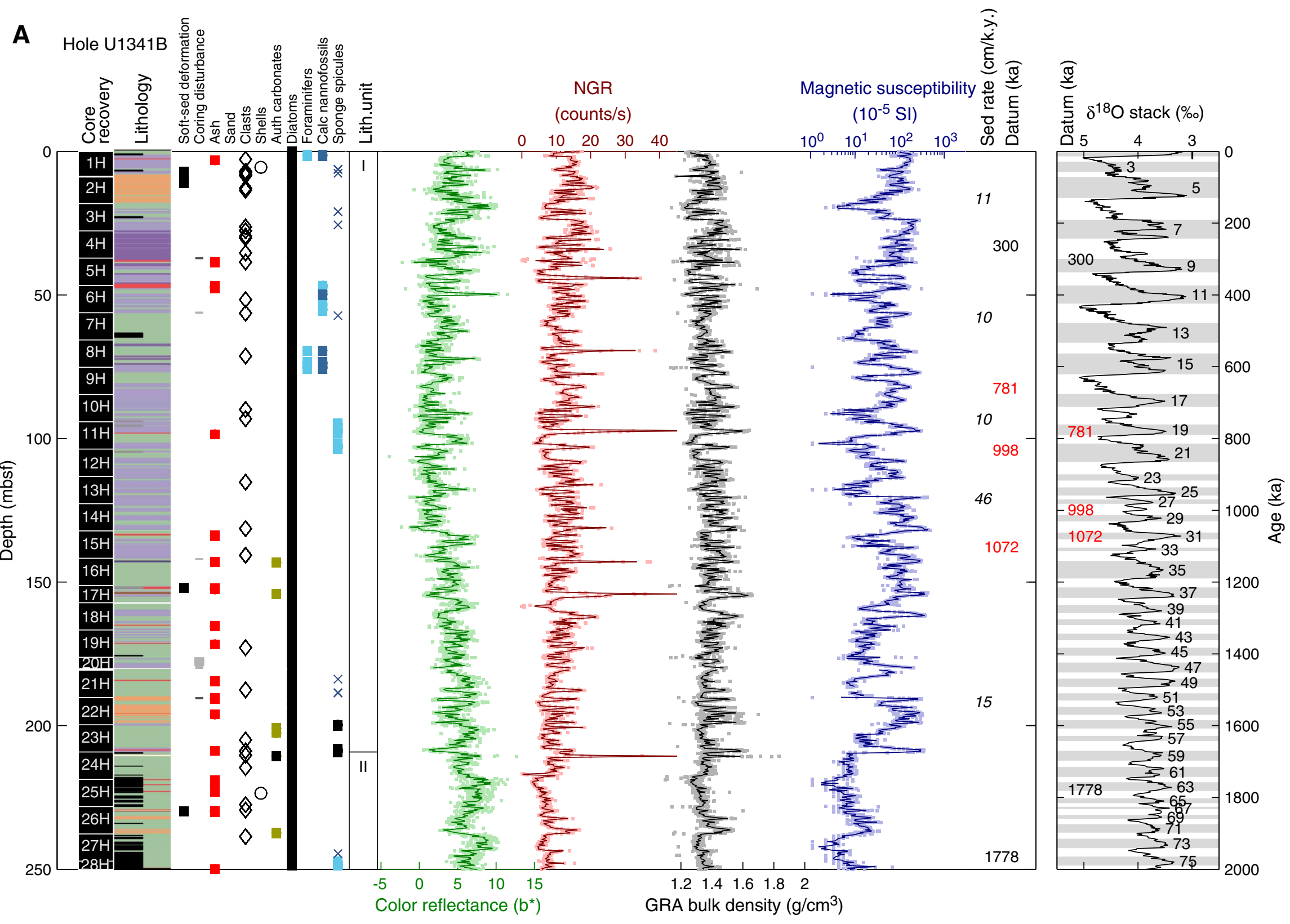


Figure F6 (continued). B. 250-500 mbsf. (Continued on next page.)

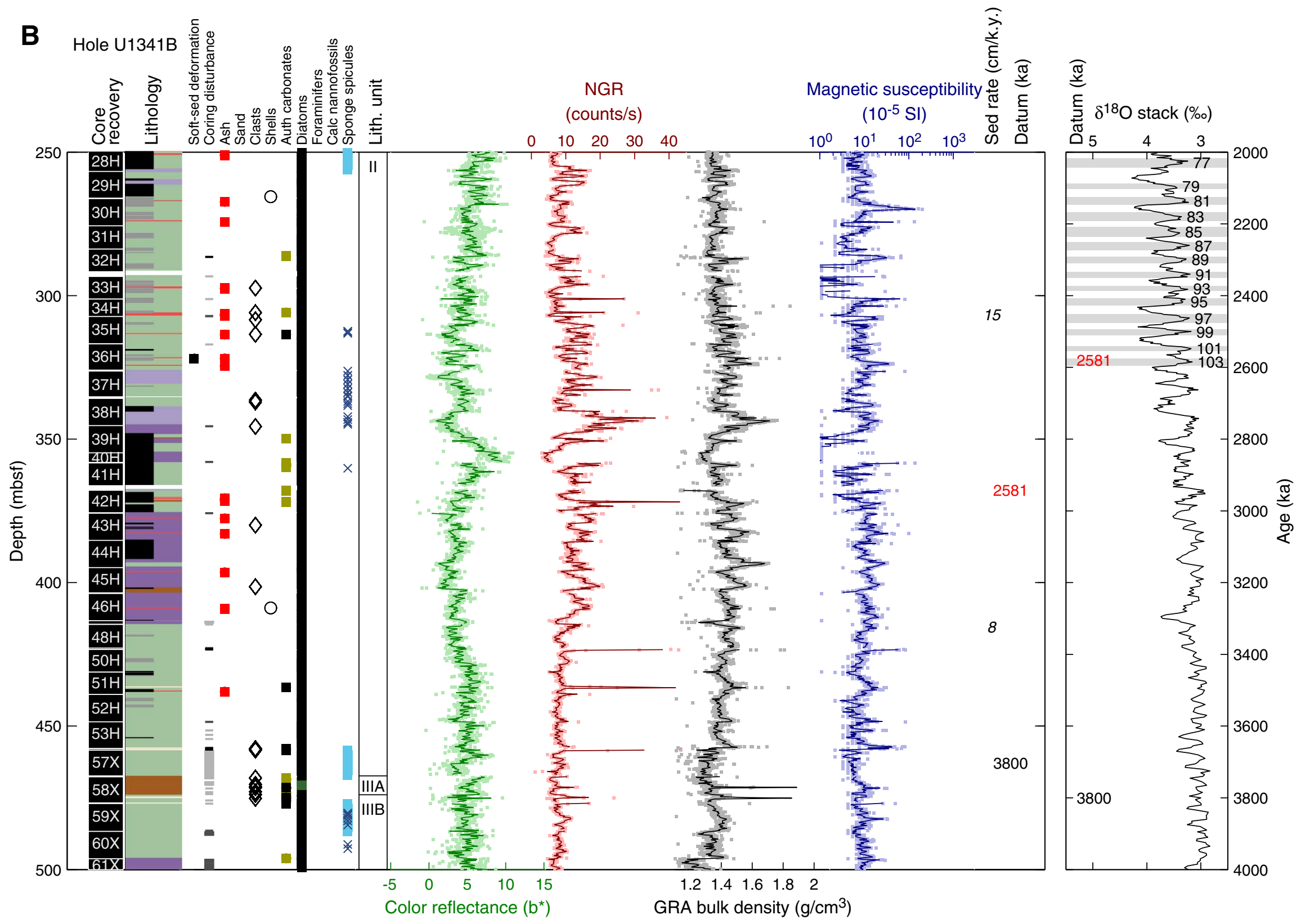


Figure F6 (continued). C. 500-750 mbsf.

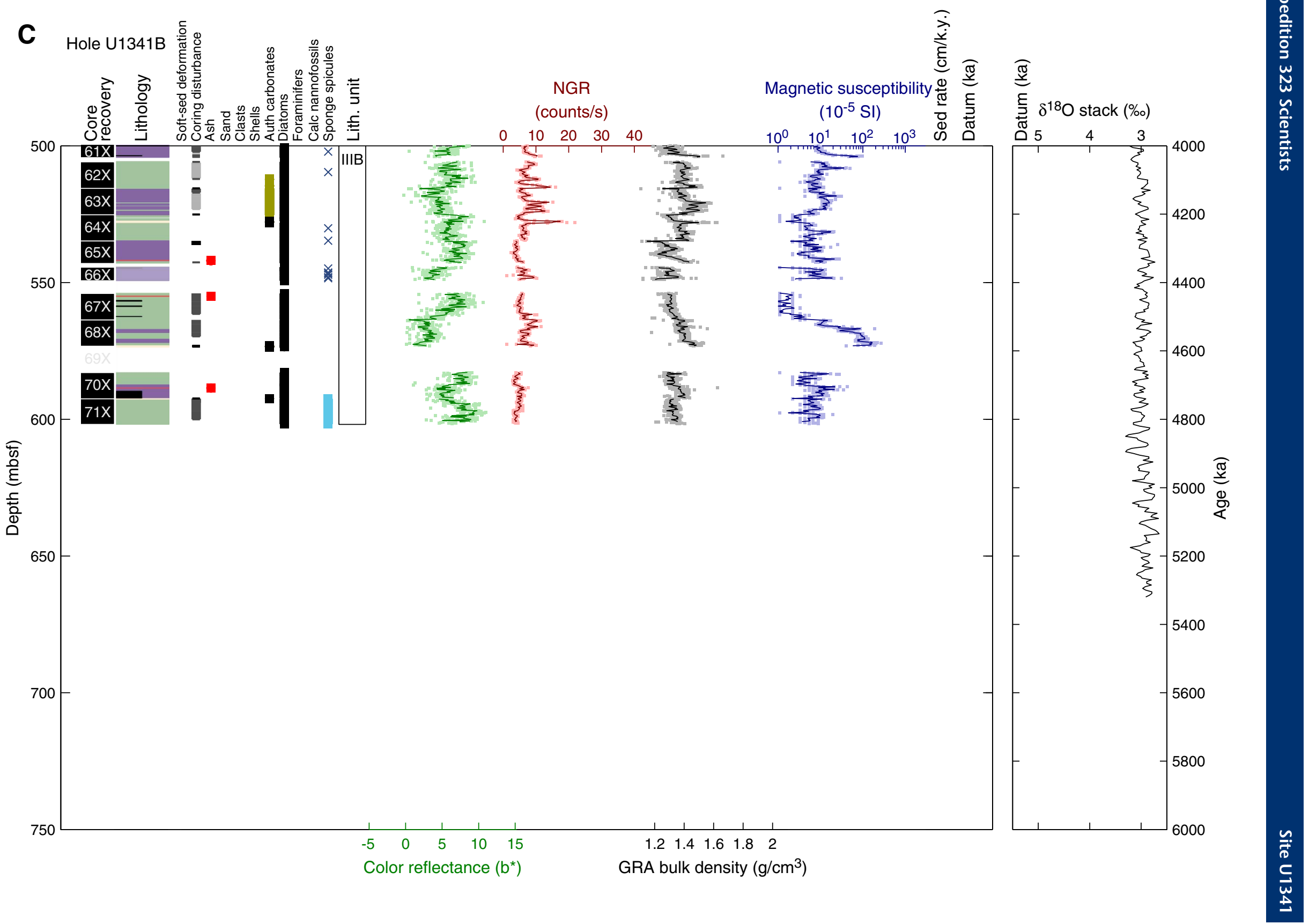


Figure F7. High-resolution core photographs of (A) laminations (Unit II; interval 323-U1341A-24H-6, 57-78 $\mathrm{cm}$ ) and (B) thin undulated bedding (Unit II; interval 323-U1341B-33H-4, 64-85 cm).

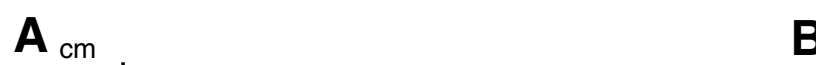

B cm
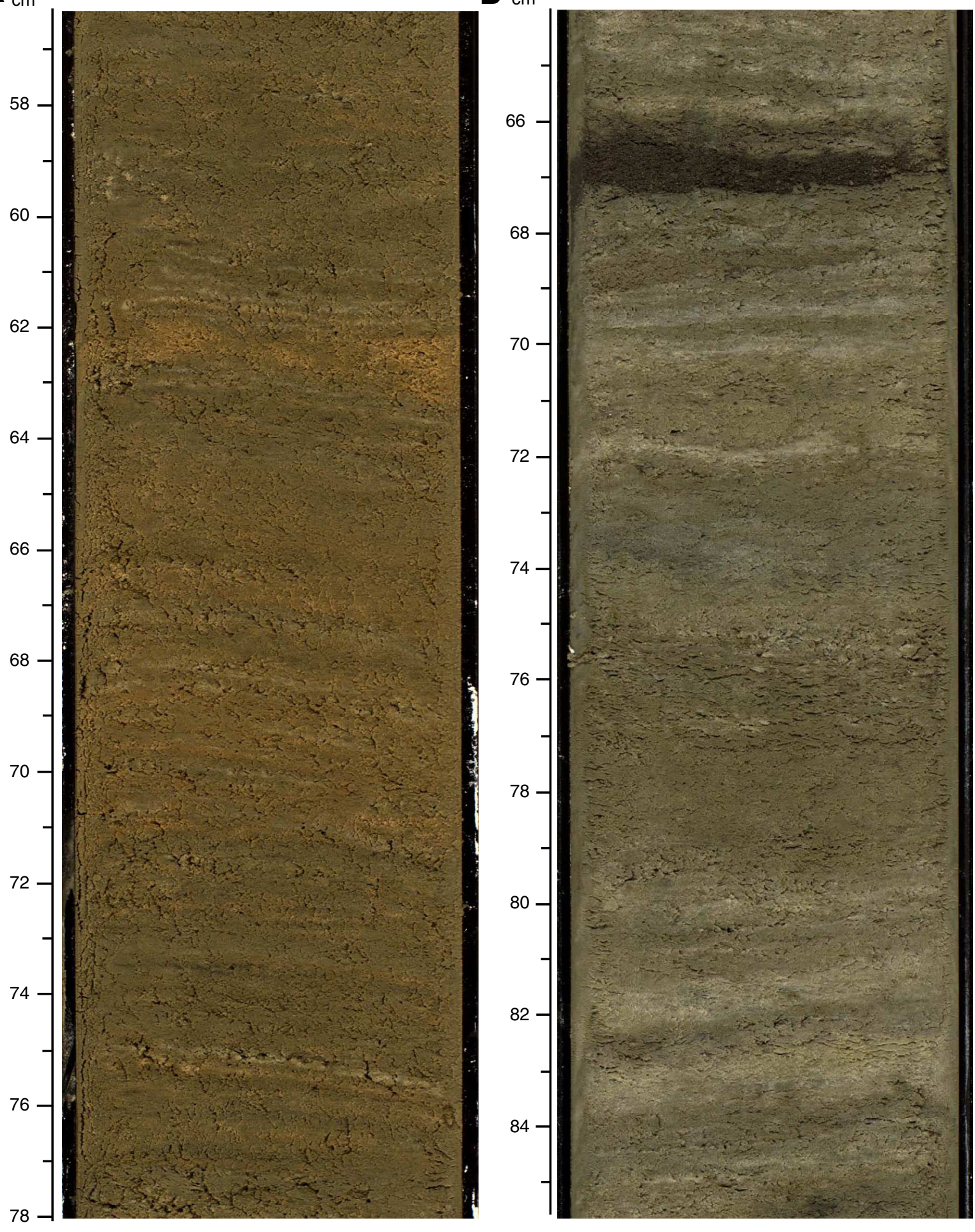
Figure F8. A. High-resolution core photograph of a semilithified authigenic carbonate-rich patch (Unit II; interval 323-U1341A-24H-6, 40-63 cm). B. High-resolution core photograph of a hard dolostone layer (Unit II; interval 323-U1341B-58X-3, 56-80 cm). C. Typical X-ray diffraction pattern of dolostone with most characteristic peaks (Unit II; Sample 323-U1341B-69X-CC, 11-16 cm). D = dolomite.
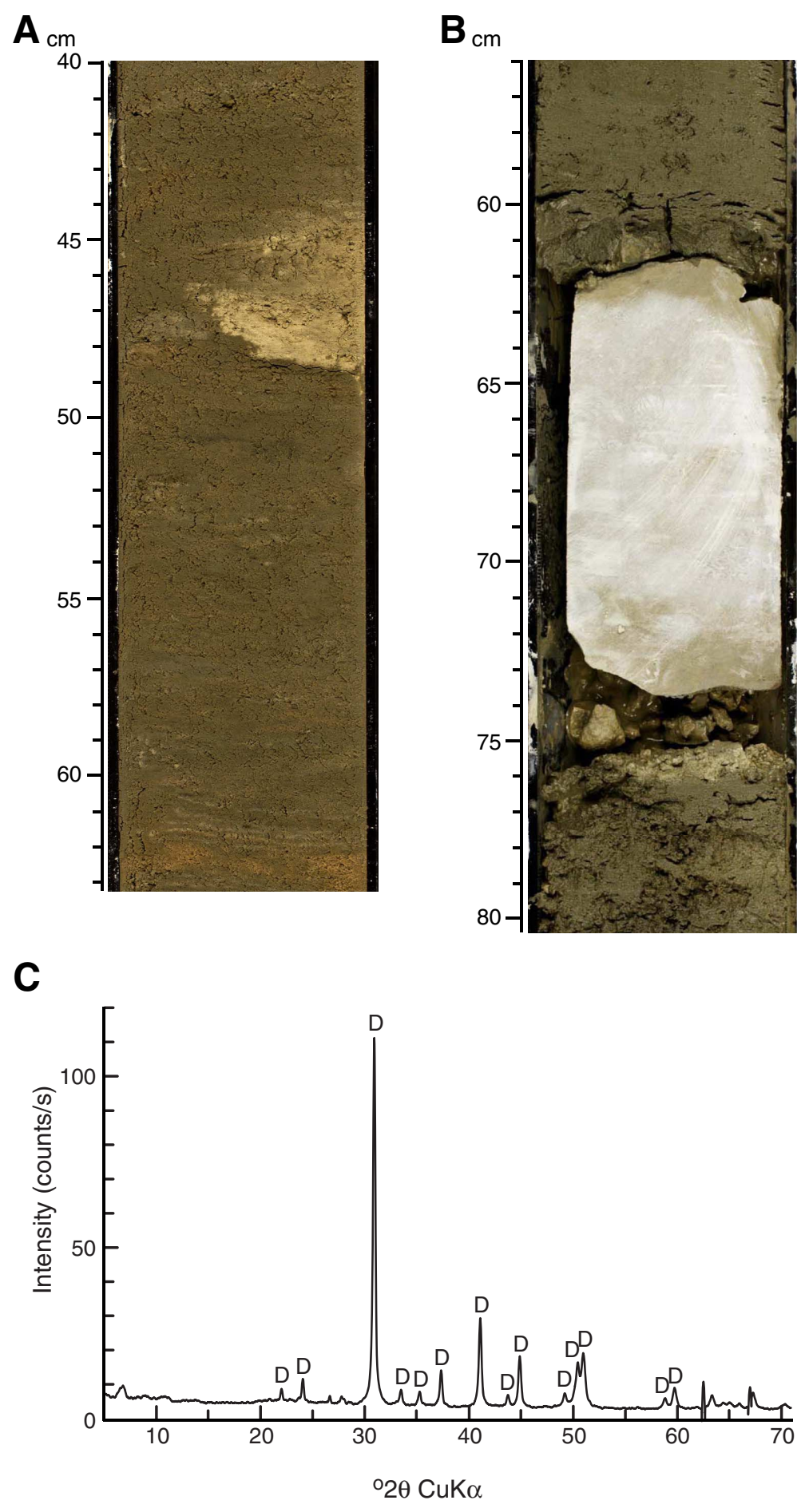
Figure F9. Summary of lithology, structures, accessories, microfossils, and physical properties, Hole U1341A. See legend in Figure F6 in the "Methods" chapter. Soft-sed = soft-sediment, auth = authigenic, calc = calcareous, NGR = natural gamma radiation, GRA = gamma ray attenuation, sed rate $=$ sedimentation rate. A. $0-250$ mbsf. (Continued on next page.)

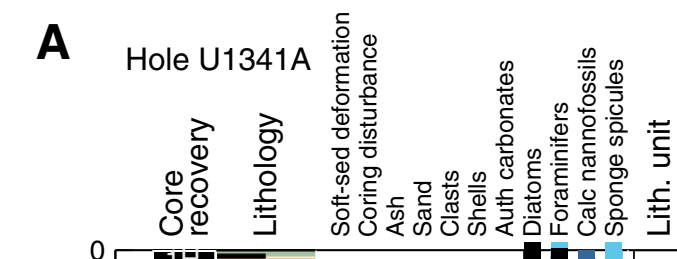

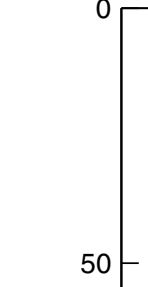

250

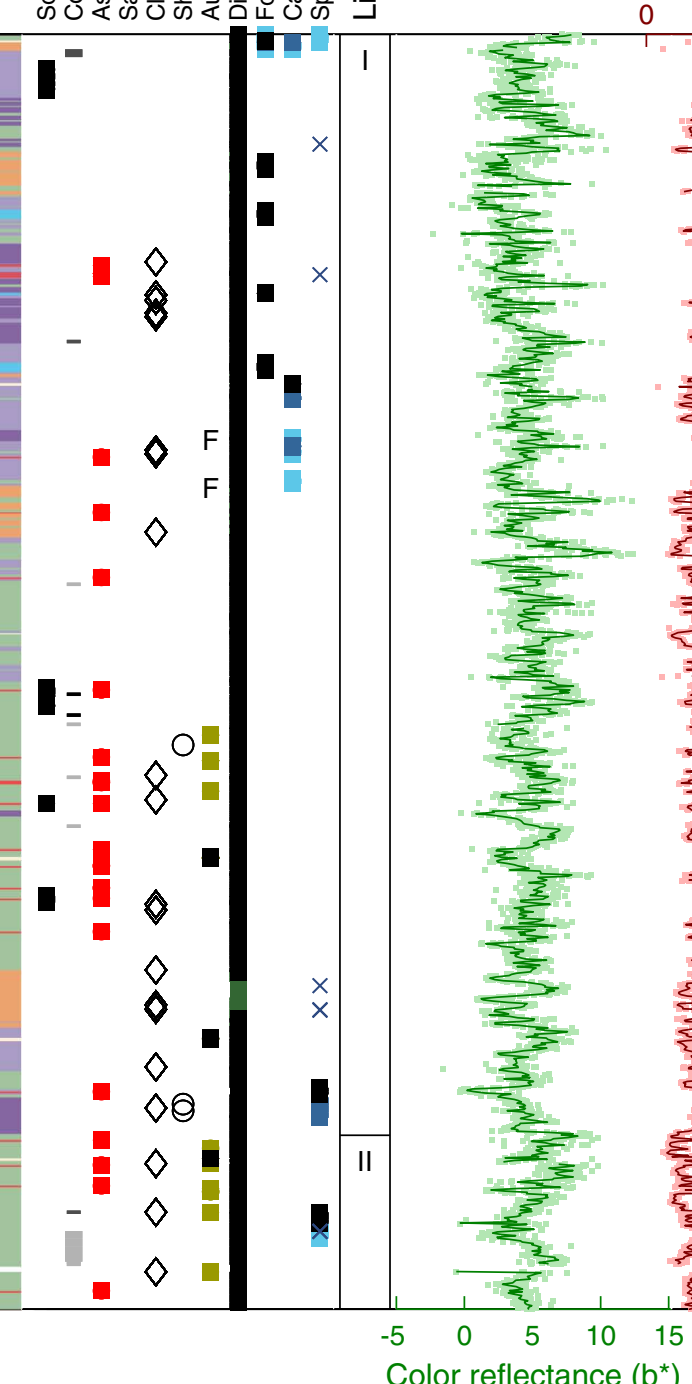

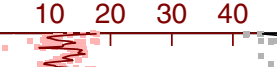
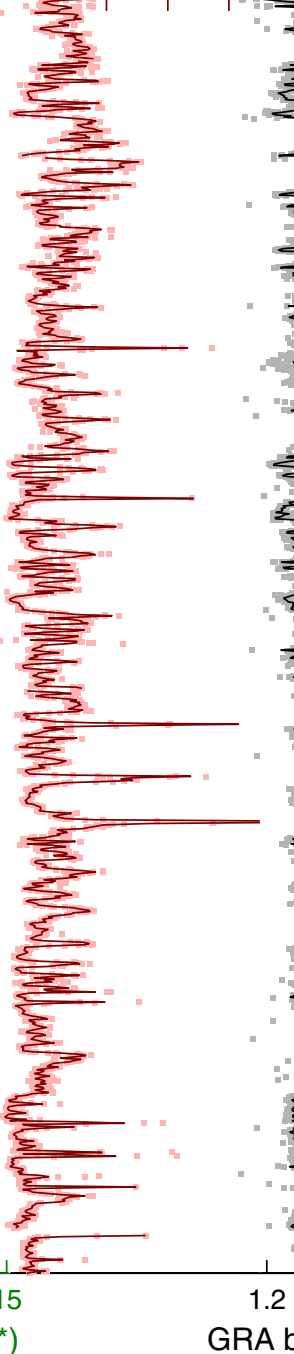
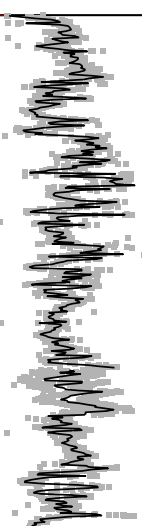
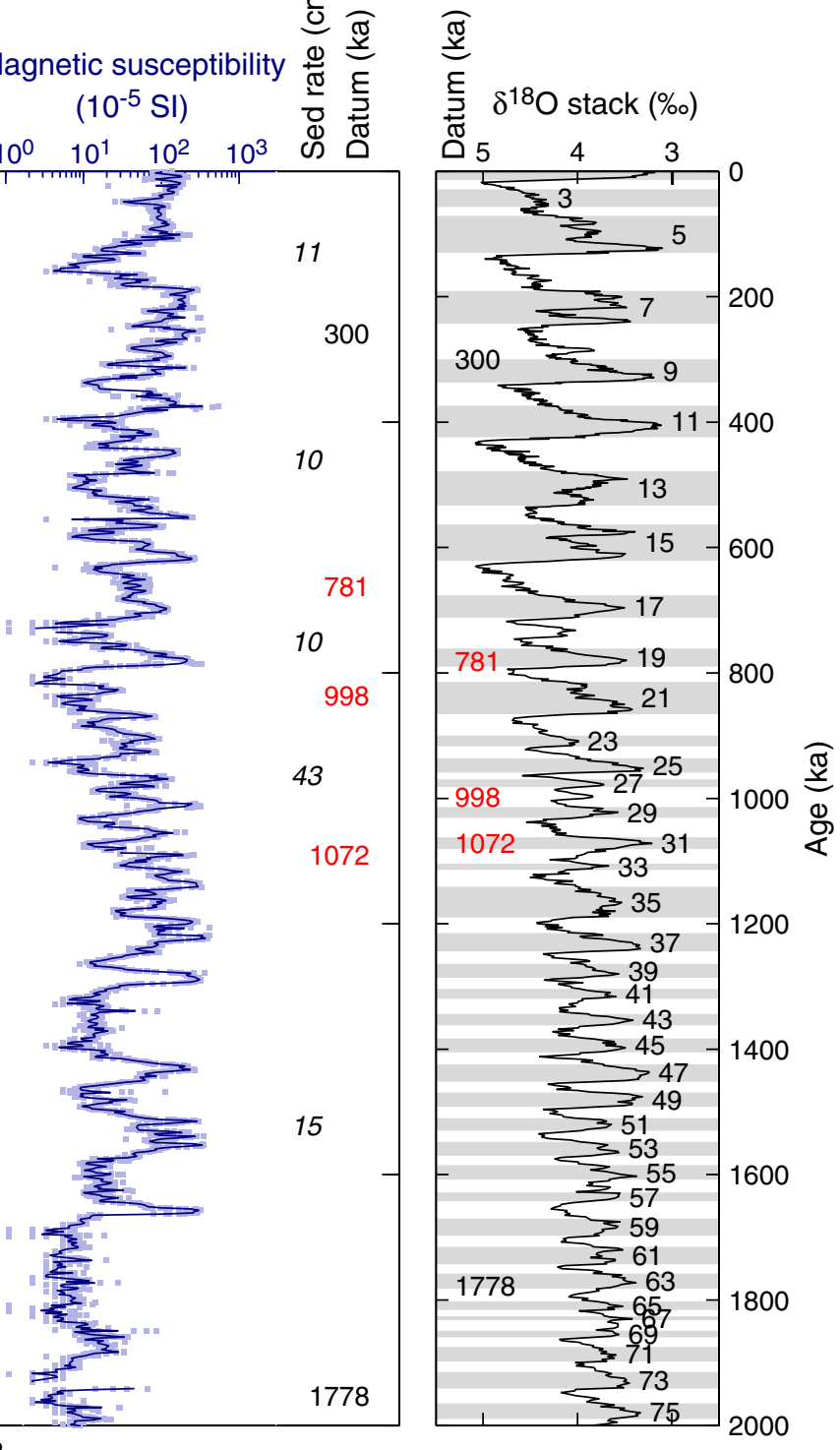

10

781

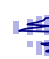
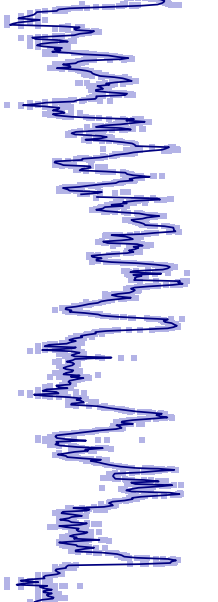

15

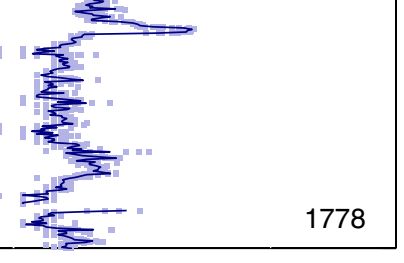

1778 
Figure F9 (continued). B. 250-500 mbsf.

B Hole U1341A

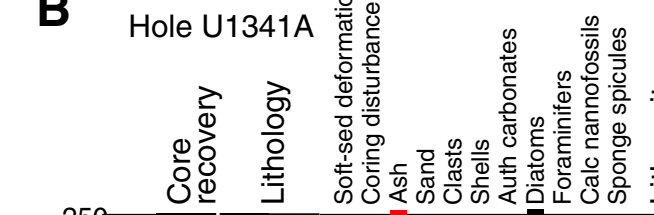

喜

$\begin{array}{cc}\text { NGR } & \text { Magnetic susceptibility } \\ \text { (counts/s) } & \left(10^{-5} \mathrm{SI}\right)\end{array}$

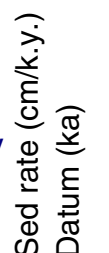

$\begin{array}{lllll}0 & 10 & 20 & 30 & 40\end{array}$

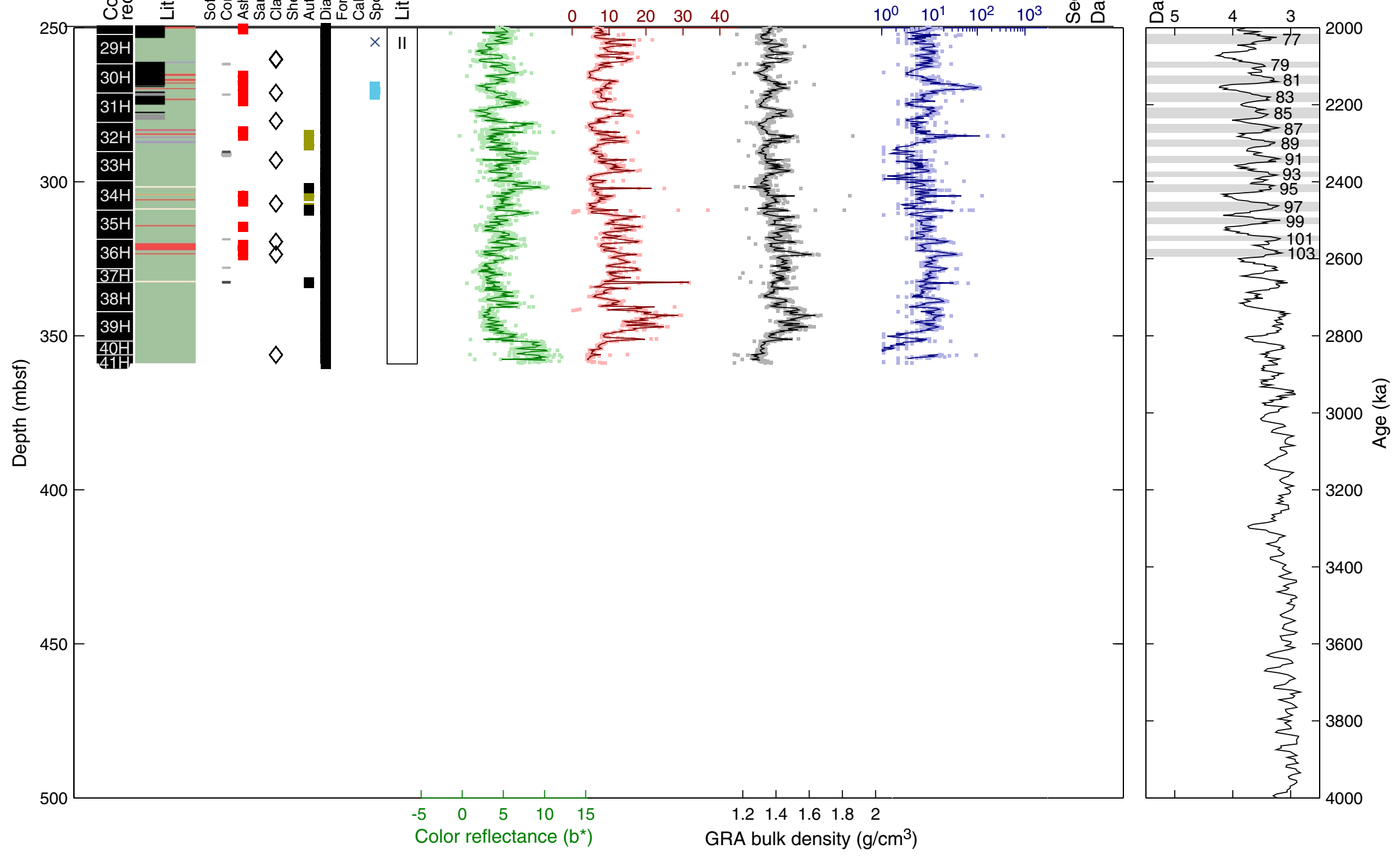

$\theta$ 
Figure F10. Summary of lithology, structures, accessories, microfossils, and physical properties, Hole U1341C. See legend in Figure F6 in the "Methods" chapter. Soft-sed = soft-sediment, auth = authigenic, calc = calcareous, NGR = natural gamma radiation, GRA = gamma ray attenuation, sed rate $=$ sedimentation rate.
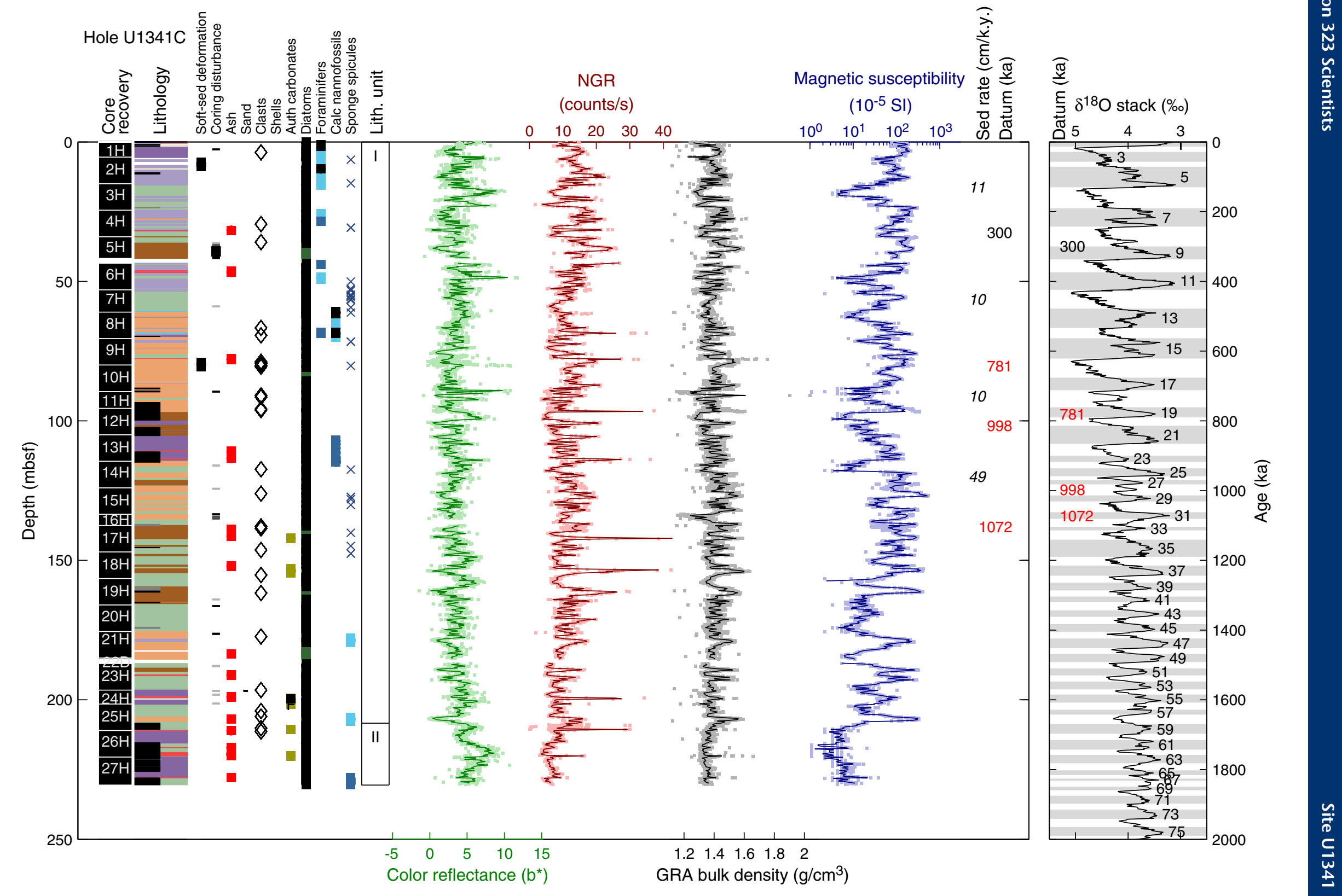
Figure F11. High-resolution core photograph of Subunit IIA (interval 323-U1341A-8H-7, 1-38 cm) showing light nannofossil diatom ooze overlaying grayish diatom silt.

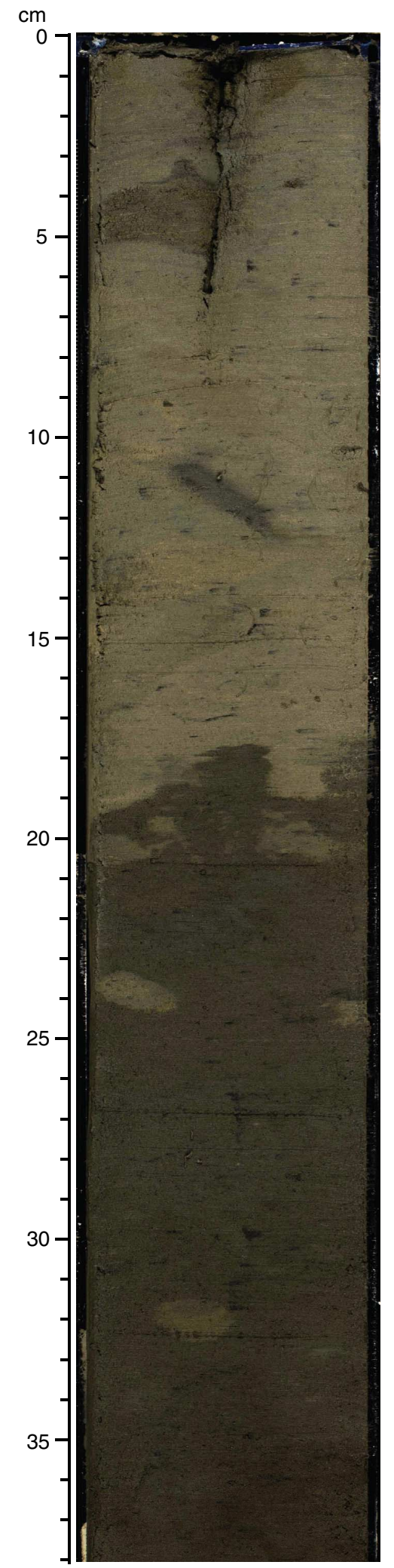


Figure F12. Age-depth plot for Site U1341 showing biostratigraphic datums based on radiolarians, diatoms, calcareous nannofossils, silicoflagellates, ebridians, and dinoflagellates. Paleomagnetic events are also shown for comparison. Biostratigraphic datums are listed in Table T2.

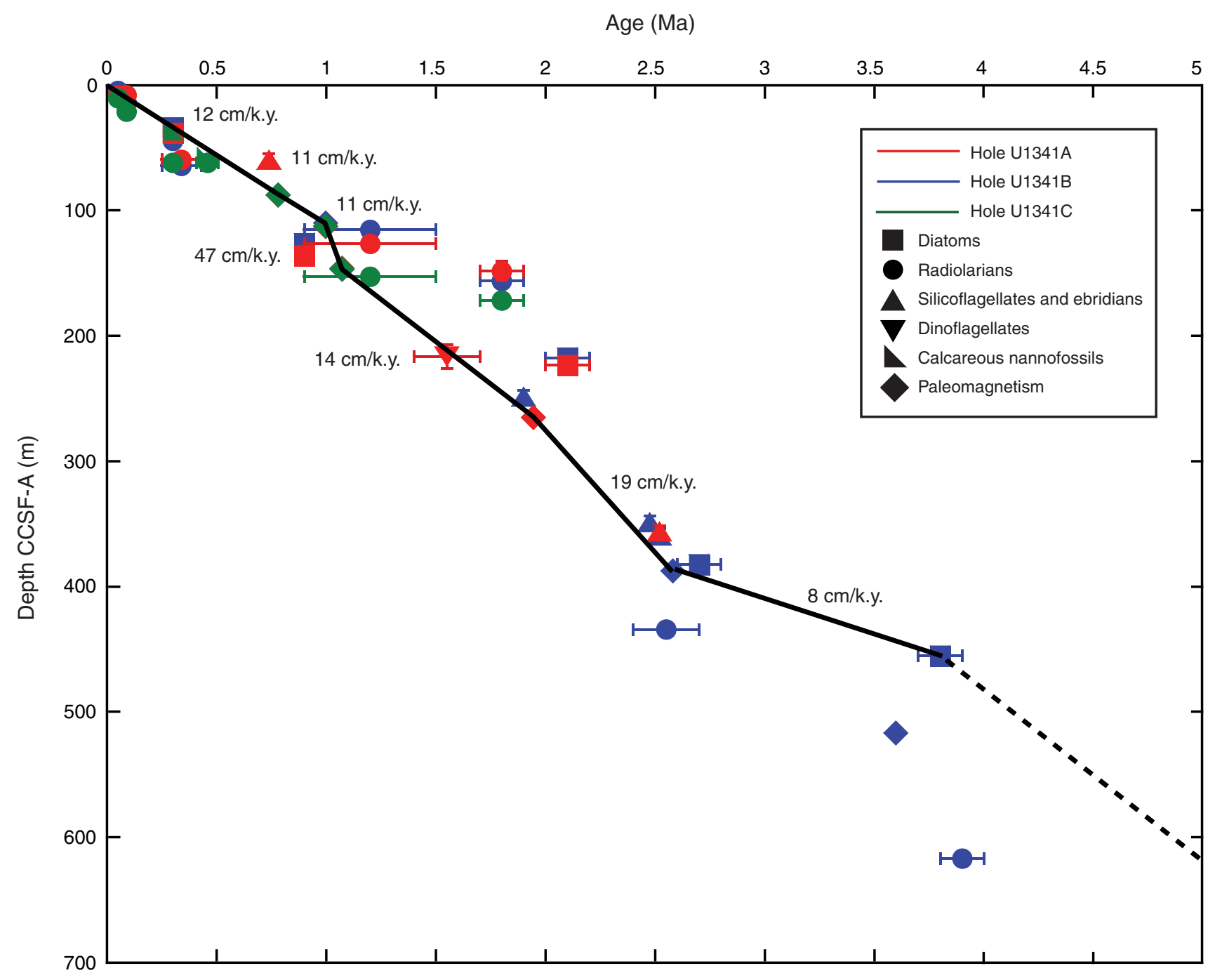


Figure F13. Abundance estimates for all major fossil groups. Sea ice diatoms include Thalassiosira antarctica spores, Bacteriosira fragilis, Porosira glacialis, and Fragilariopsis cylindrus. Sea ice dinoflagellate cysts include Islandinium minutum, Operculodinium centrocarpum (Arctic morphotype), and Impagidinium minutum. For calcareous nannofossil and benthic foraminifer abundances, $\mathrm{B}=\mathrm{barren}, \mathrm{P}=\mathrm{present}, \mathrm{R}=\mathrm{rare}, \mathrm{F}=\mathrm{few}, \mathrm{C}=\mathrm{common}$, $\mathrm{A}=$ abundant, and $\mathrm{D}=$ dominant. For benthic foraminifer abundance estimates, see "Biostratigraphy" in the "Methods" chapter.
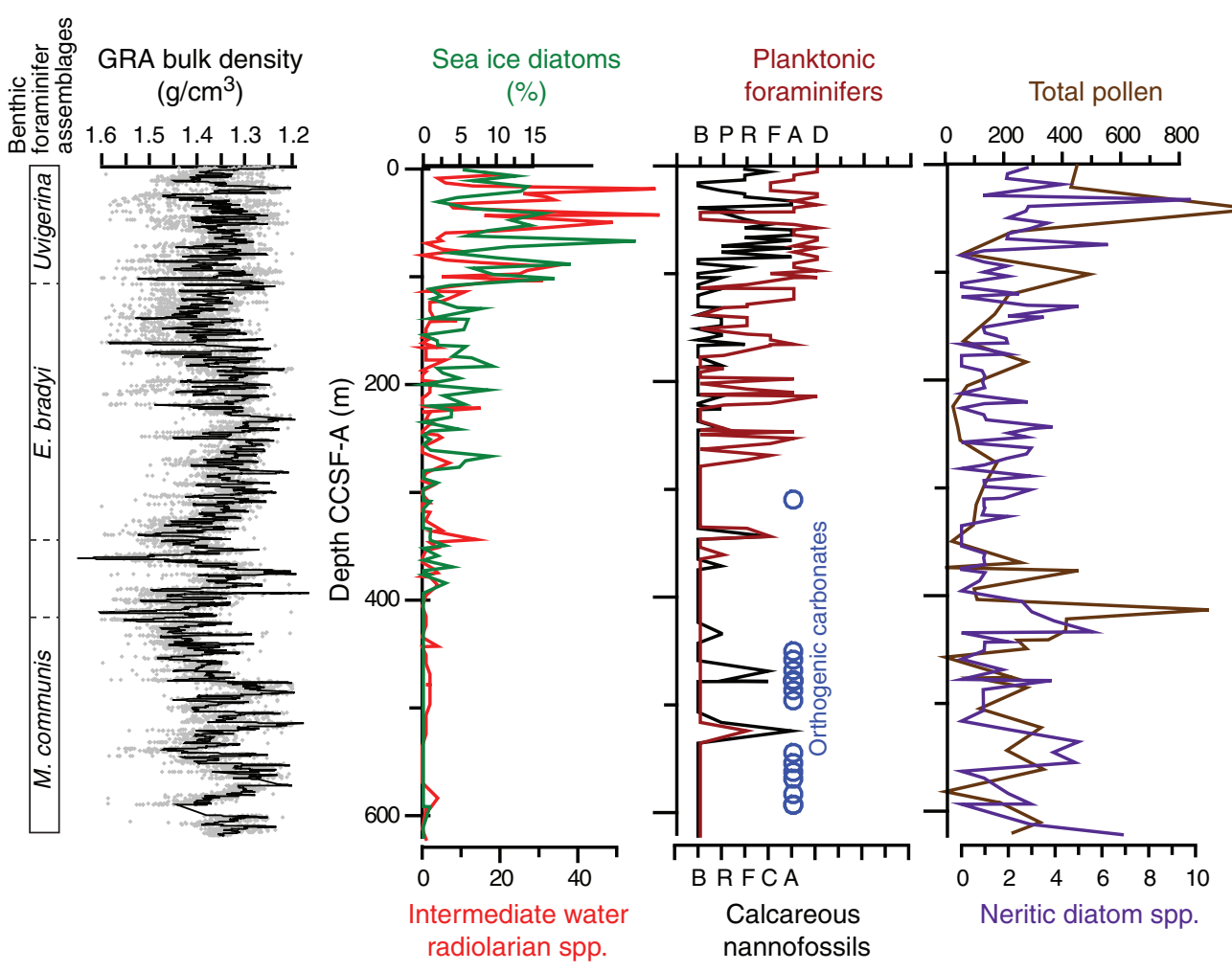
Figure F14. Biostratigraphic events in Holes U1340A and U1341B used for stratigraphic correlation between sites. Neodenticula seminae and Neodenticula kamtschatica percentages were used as the primary biostratigraphic events. Other biostratigraphic and magnetostratigraphic events are also included. BM = Brunhes/Matuyama. $\mathrm{T}=$ top, $\mathrm{B}=$ bottom $. \mathrm{FO}=$ first occurrence, $\mathrm{LO}=$ last occurrence, $\mathrm{RI}=$ rapid increase. $\mathrm{APC}=$ advanced piston corer, $\mathrm{XCB}=$ extended core barrel.

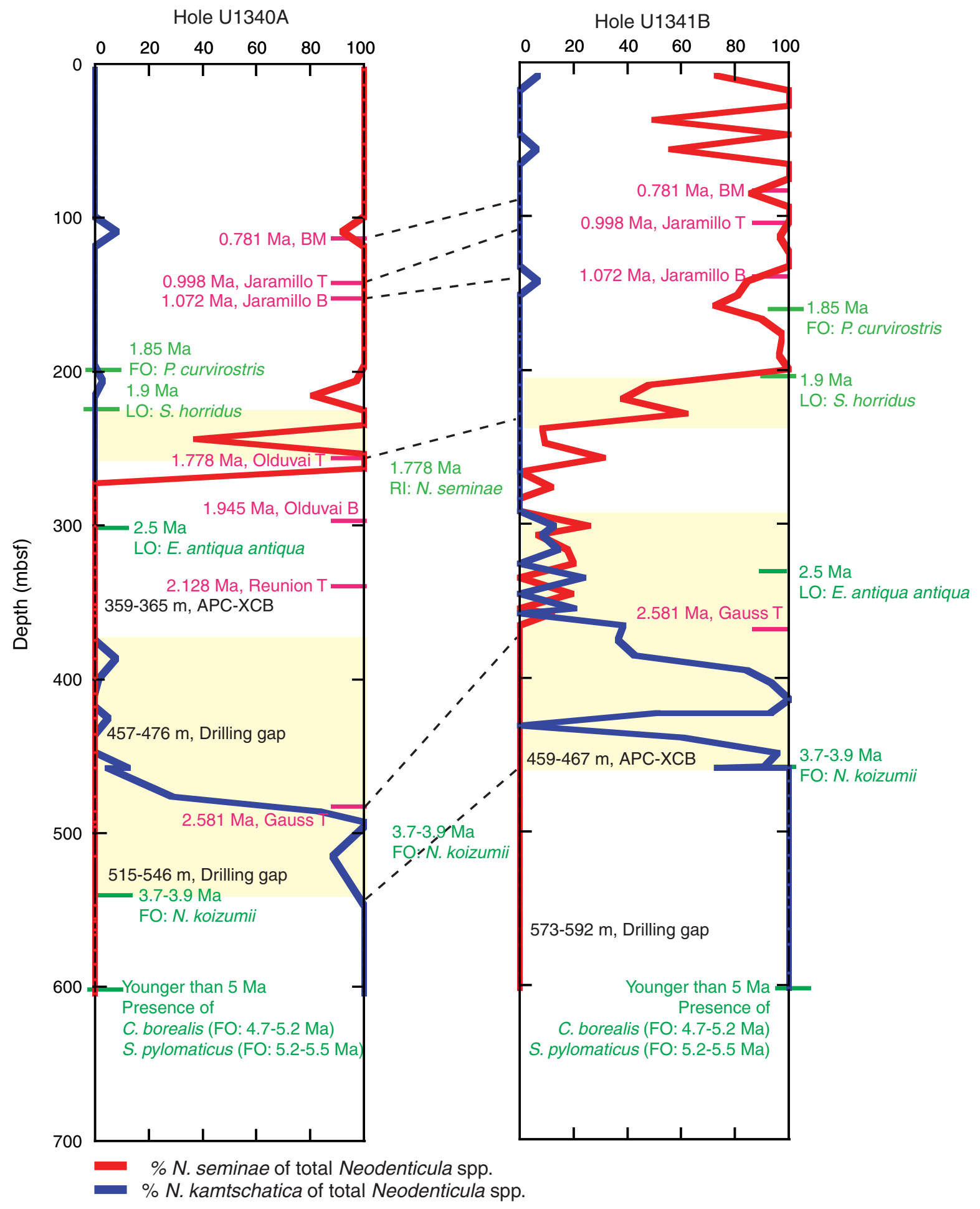


Figure F15. Inclination, declination, and intensity of remanent magnetization after $20 \mathrm{mT}$ AF demagnetization $\left(\right.$ Int $\left._{20 \mathrm{mT}}\right)$, Hole U1341A. Intensity data (black) are shown with STMSL magnetic susceptibility data (red). In the declination diagram, blue dots = raw data and black dots = values corrected using FlexIt orientation tool data.

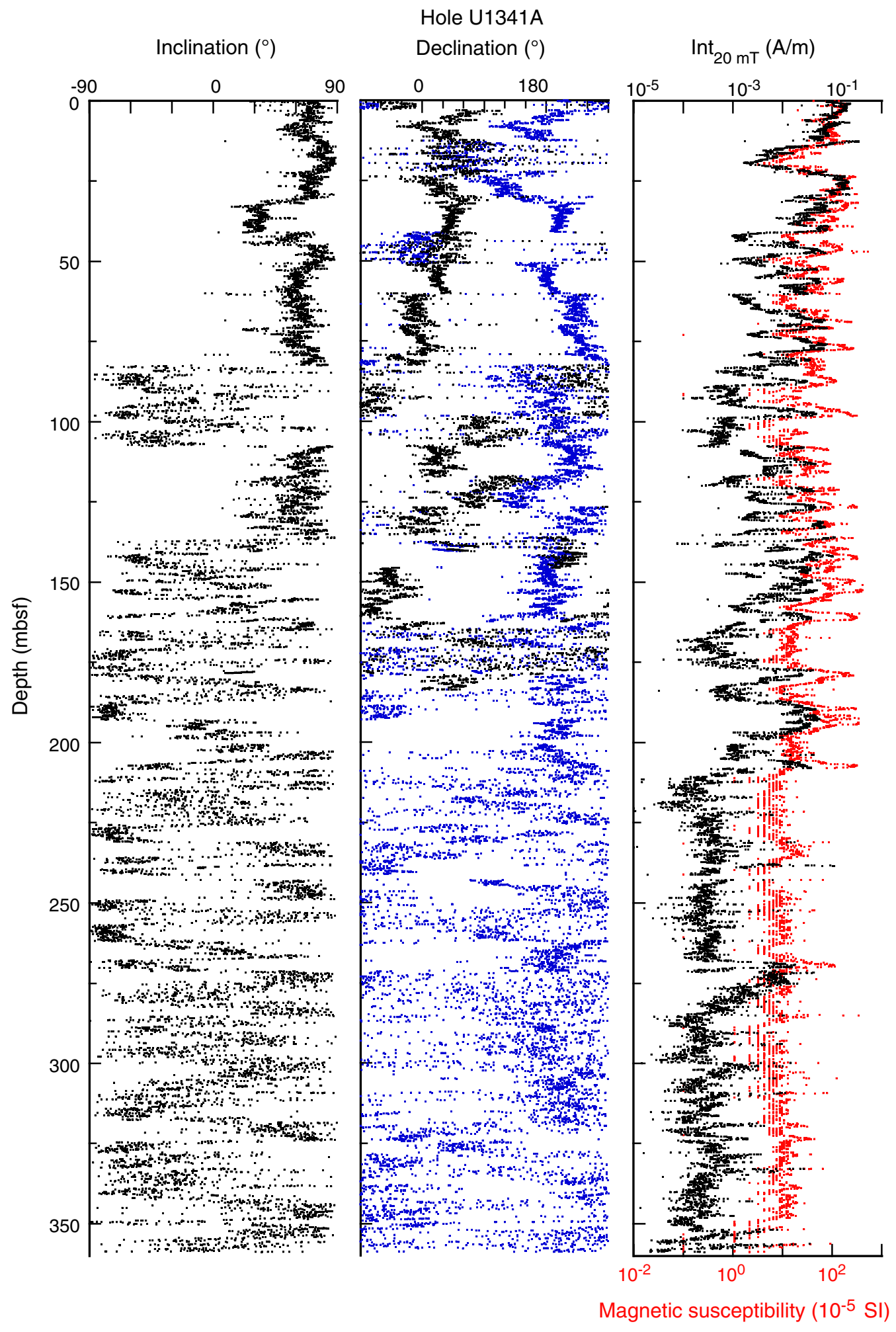


Figure F16. Inclination, declination, and intensity of remanent magnetization after $20 \mathrm{mT}$ AF demagnetization $\left(\right.$ Int $\left._{20 \mathrm{mT}}\right)$, Hole U1341B. Intensity data (black) are shown with STMSL magnetic susceptibility data (red). In the declination diagram, blue dots $=$ raw data and black dots $=$ values corrected using FlexIt orientation tool data.

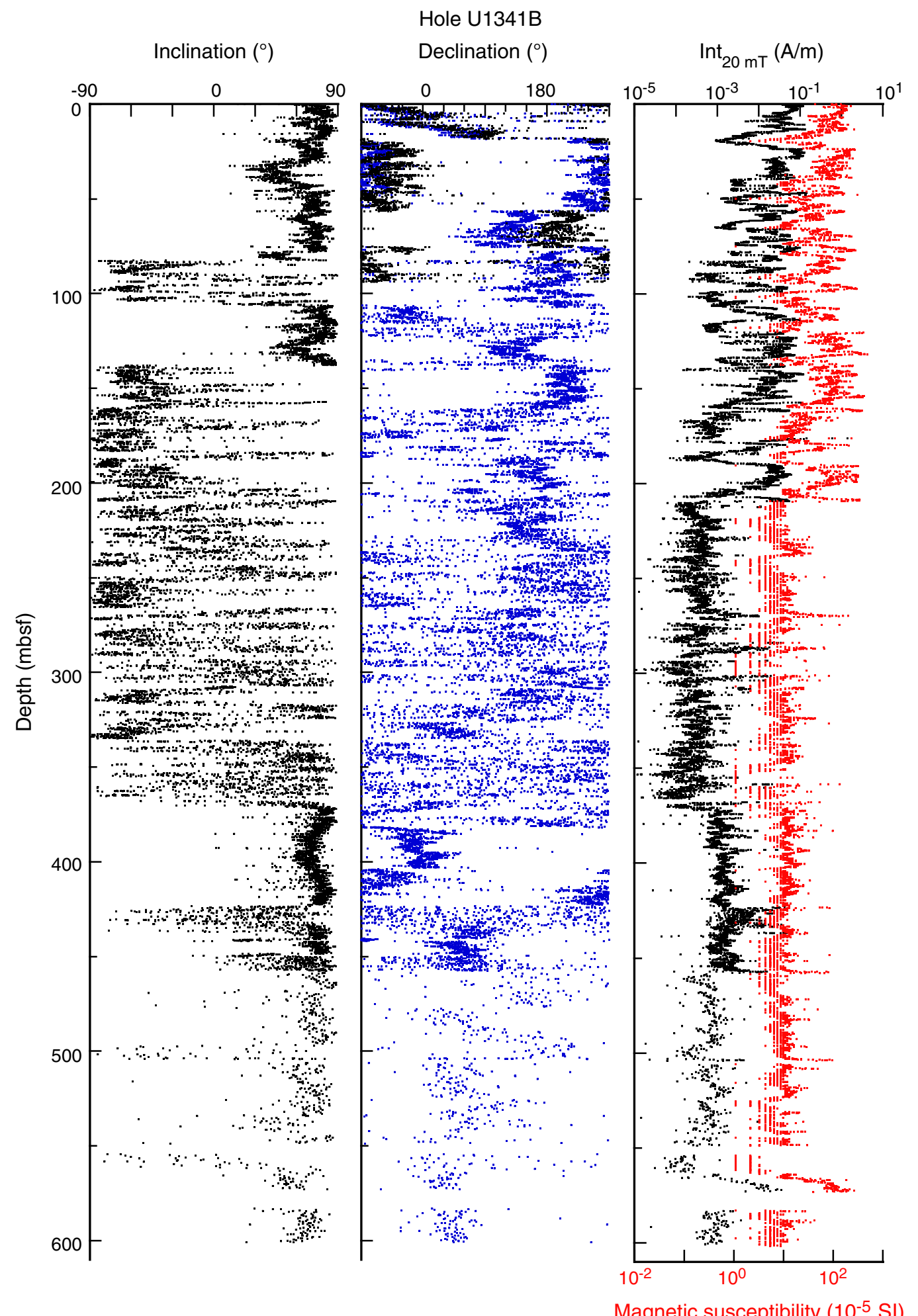


Figure F17. Inclination, declination, and intensity of remanent magnetization after $20 \mathrm{mT}$ AF demagnetization $\left(\mathrm{Int}_{20 \mathrm{mT}}\right)$, Hole U1341C. Intensity data (black) are shown with STMSL magnetic susceptibility data (red). Declination data have been corrected using FlexIt orientation tool data.

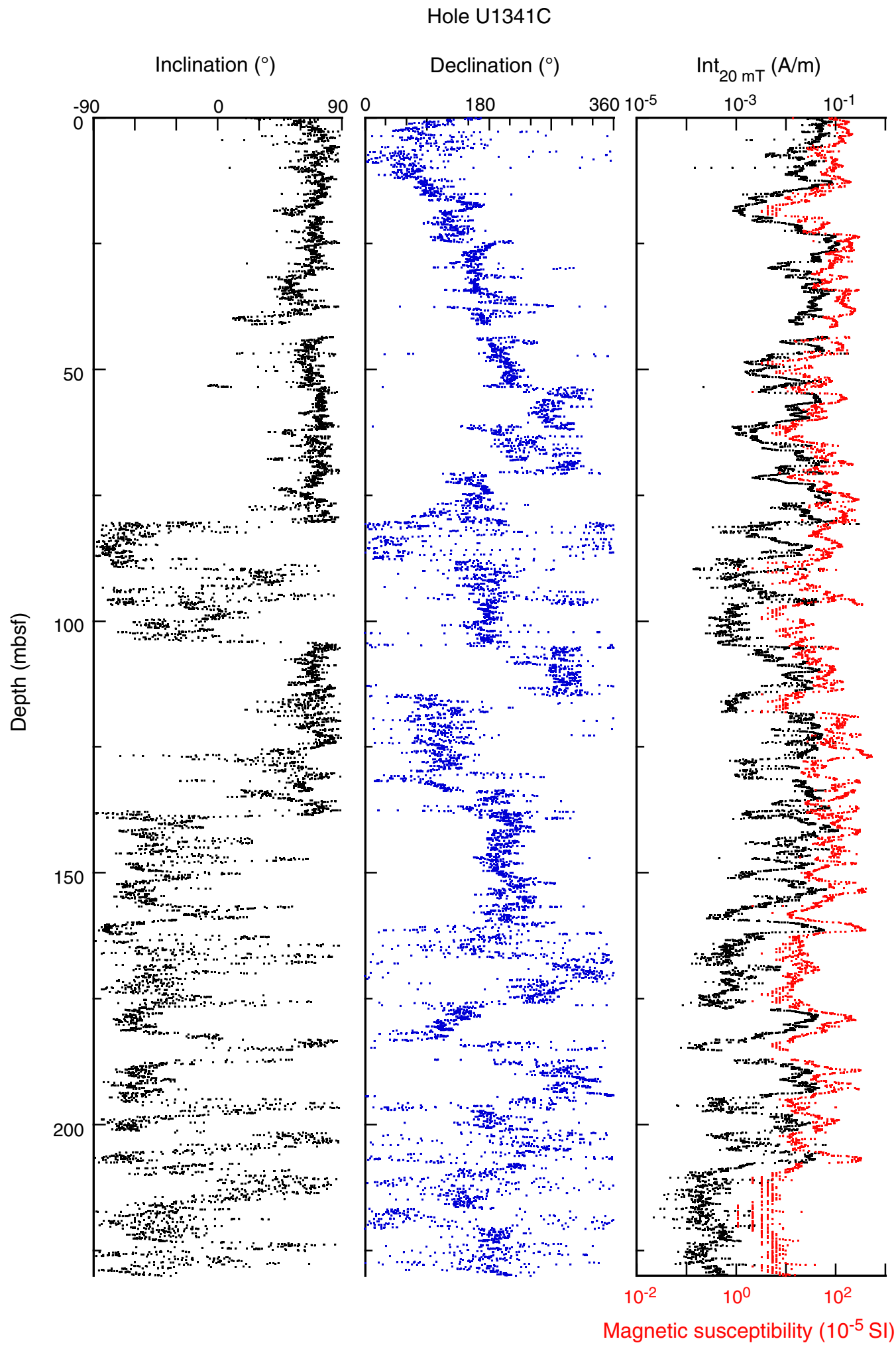


Figure F18. Averaged (60 point; corresponding to $1.5 \mathrm{~m}$ ) inclination for all Hole U1341B cores, along with tentative polarity zonation (black $=$ normal polarity, white $=$ reversed polarity, and gray $=$ uncertain polarity) and presumable correlation with the polarity chrons.
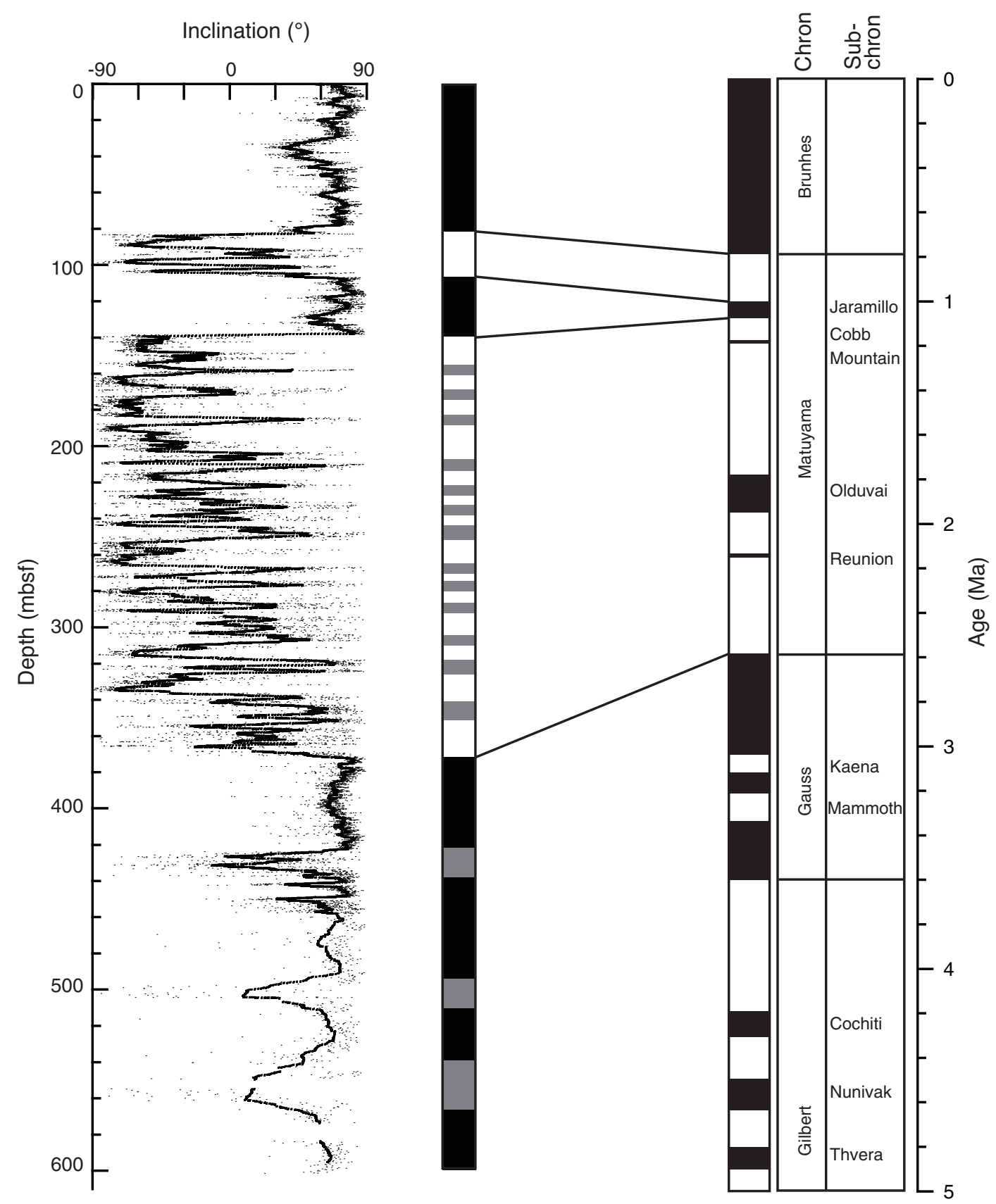
Figure F19. Ratio of intensity of remanent magnetization after $20 \mathrm{mT} \mathrm{AF} \mathrm{demagnetization} \mathrm{(Int} 20 \mathrm{mT}$ ) and magnetic susceptibility (our relative paleointensity estimate) to benthic foraminifer diversity, Hole U1341B.

Hole U1341B

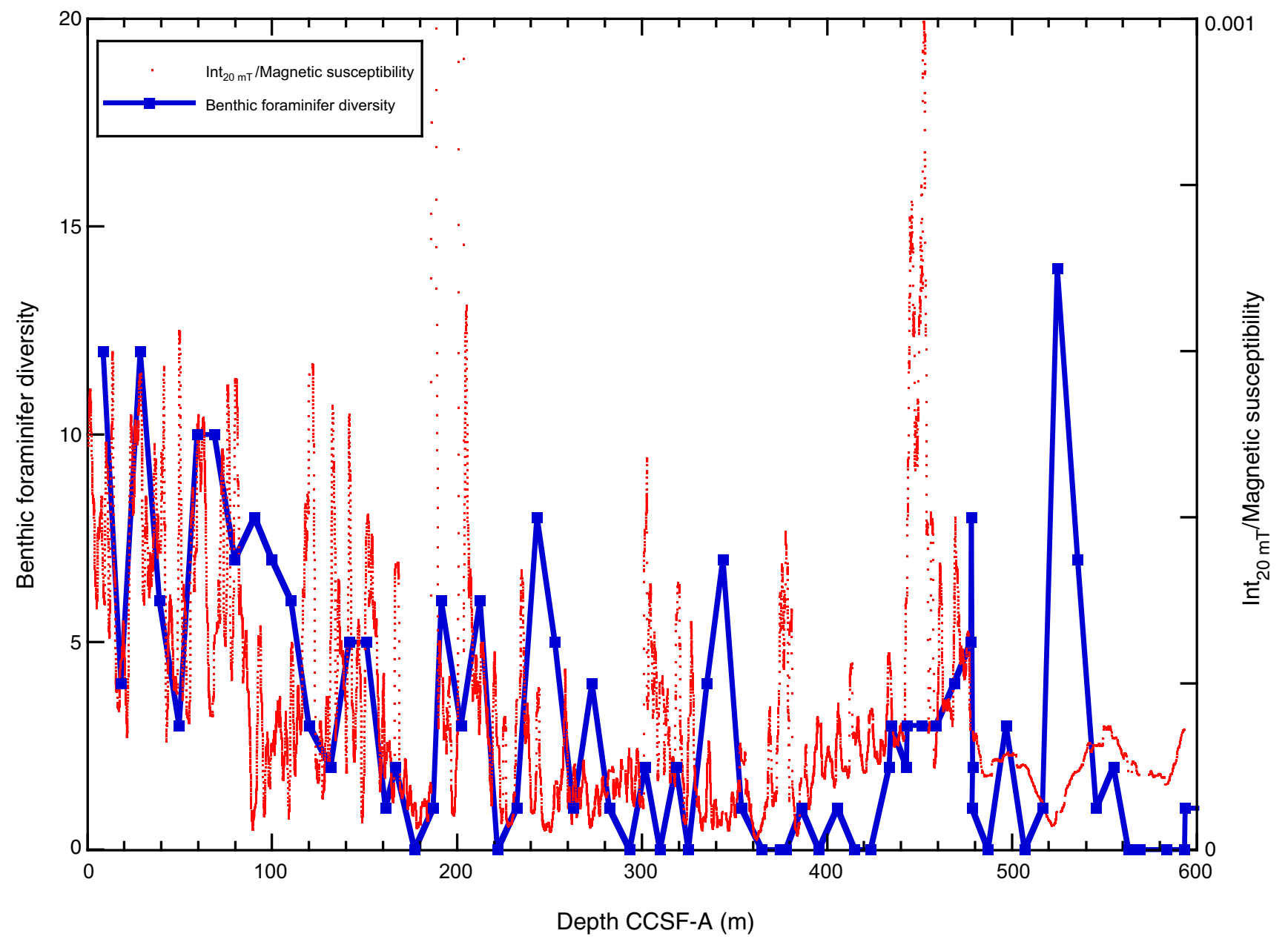


Figure F20. Inclination after $20 \mathrm{mT}$ AF demagnetization for Holes U1341A, U1341B, and U1341C, plotted for intervals where the Brunhes/Matuyama polarity transition was observed.

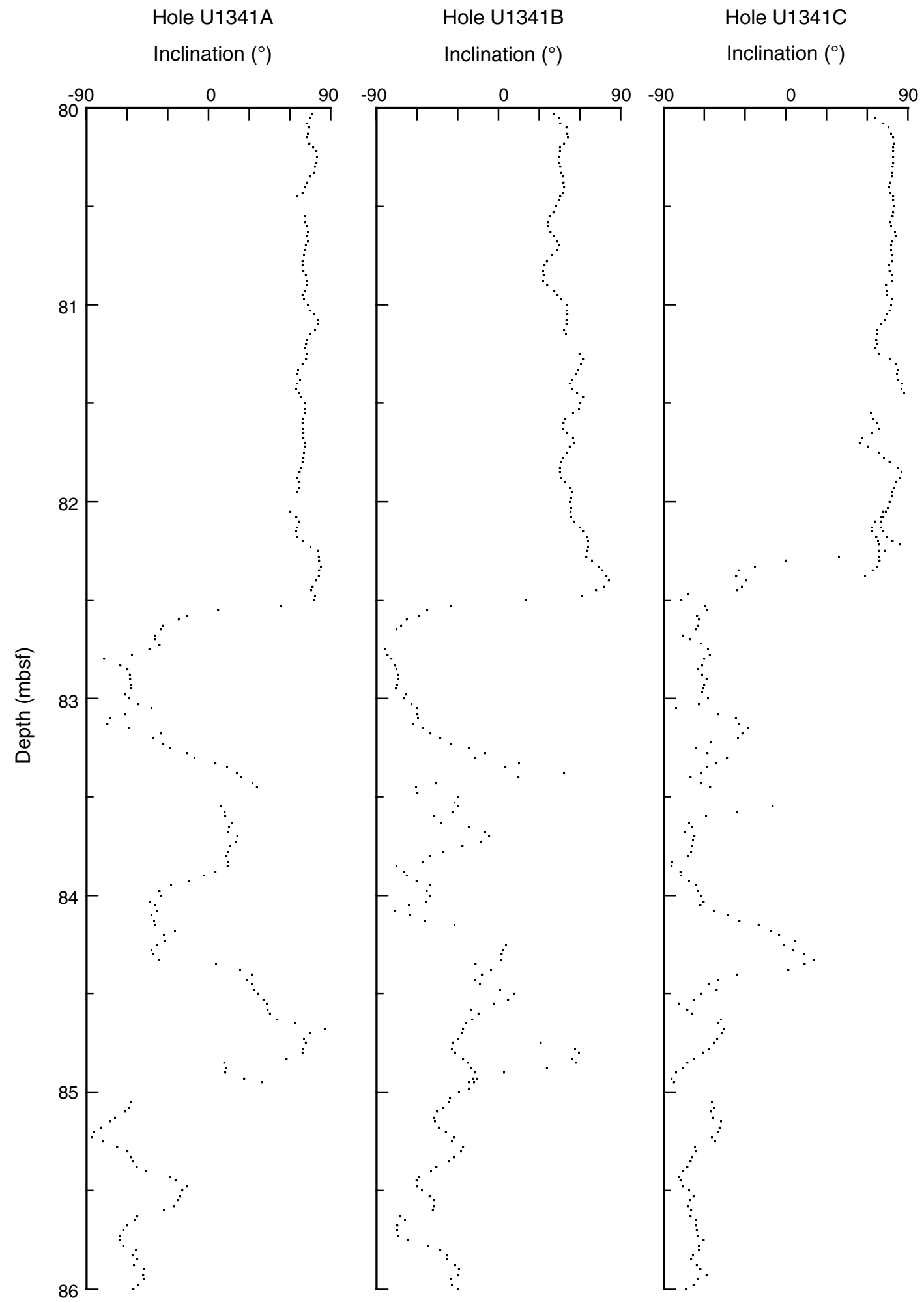


Figure F21. Dissolved chemical concentrations, Holes U1341A and U1341B. A. Dissolved inorganic carbon (DIC). B. pH. C. Alkalinity. D. Sulfate. E. Total hydrogen sulfide $\left(\mathrm{LH}_{2} \mathrm{~S}=\mathrm{H}_{2} \mathrm{~S}+\mathrm{HS}^{-}\right)$. F. Methane. G. Phosphate. H. Ammonium. I. Salinity.
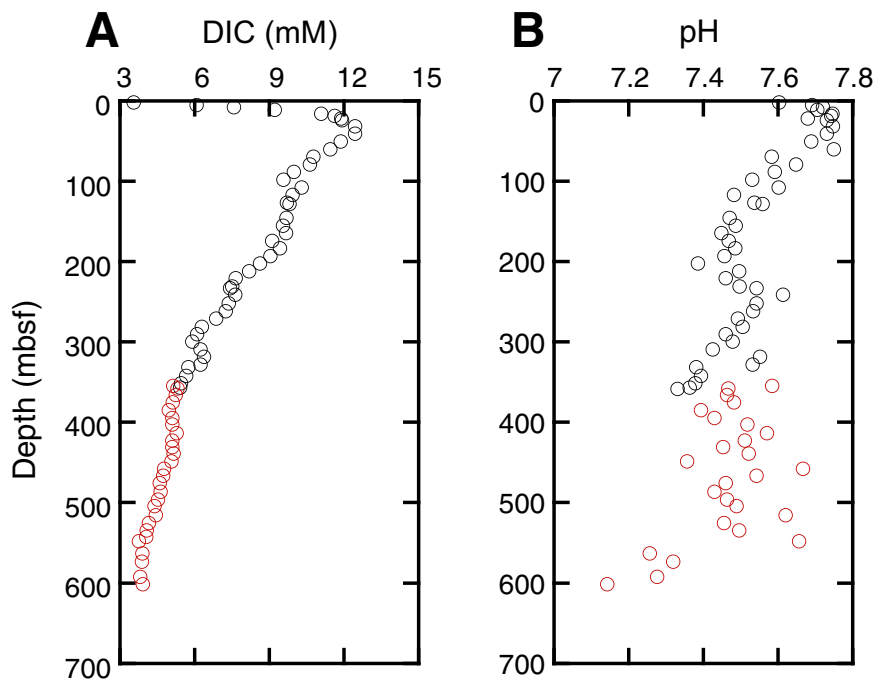

C Alkalinity $(\mathrm{mM})$
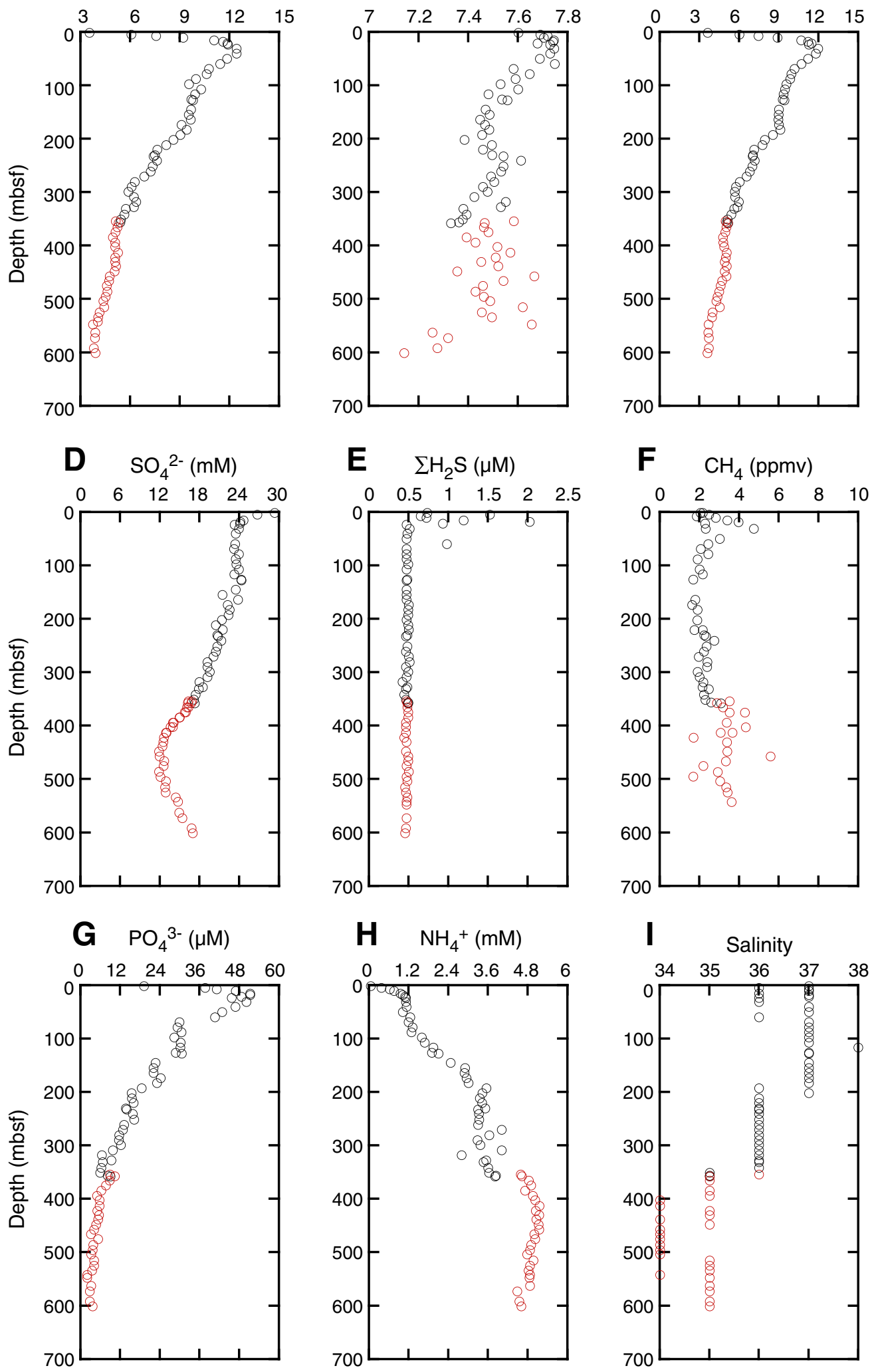

- Hole U1341A $\bigcirc$ Hole U1341B

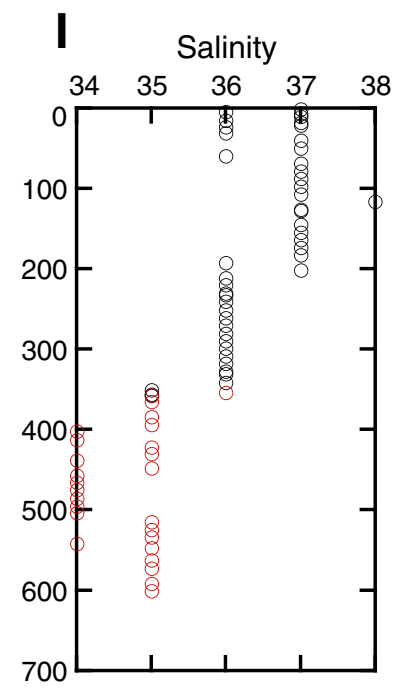


Figure F22. Dissolved chemical concentrations, Holes U1341A and U1341B. A. Calcium. B. Magnesium. C. Chloride. D. Sodium. E. Potassium. F. Strontium. G. Barium. H. Iron. I. Lithium. J. Boron. K. Silica. L. Manganese.
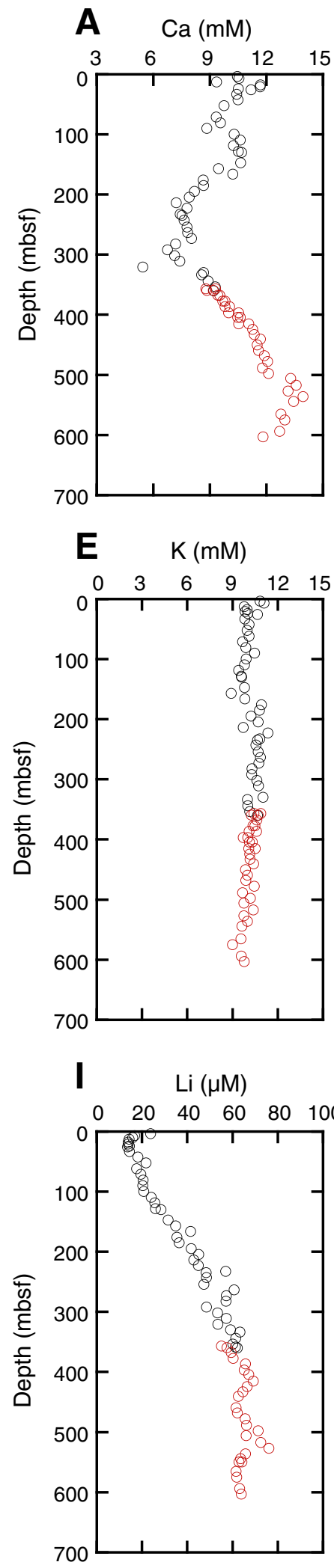

B $\mathrm{Mg}(\mathrm{mM})$

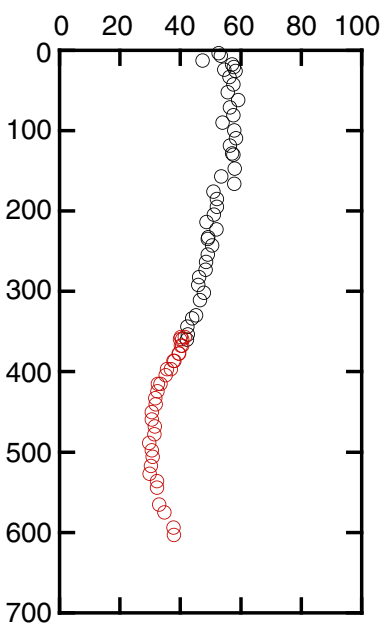

F $\quad \operatorname{Sr}(\mu \mathrm{M})$

$6080 \quad 100120140160$

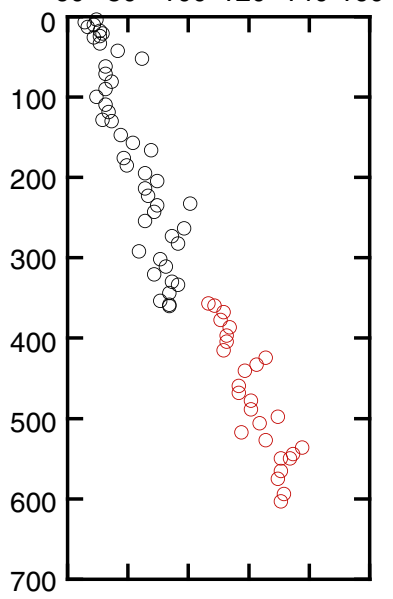

J $B(\mu \mathrm{M})$

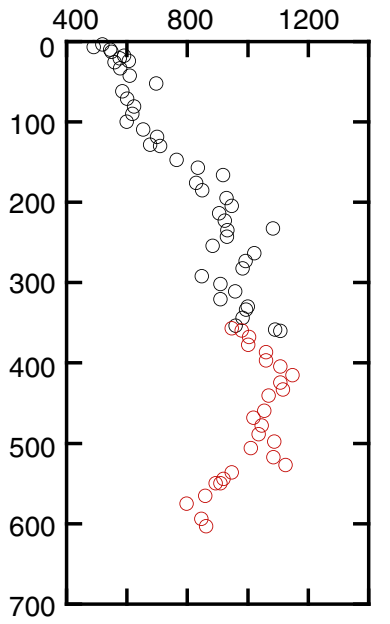

C $\quad \mathrm{Cl}^{-}(\mathrm{mM})$

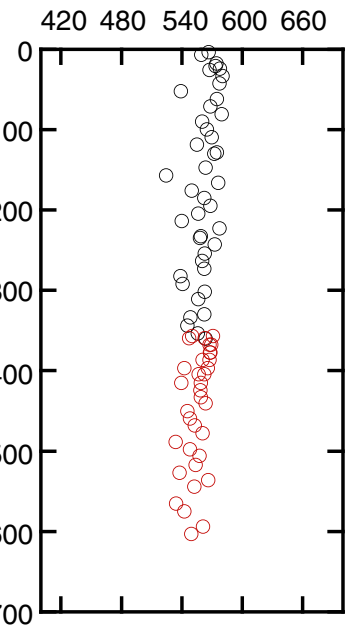

G $\quad \mathrm{Ba}(\mu \mathrm{M})$

$\begin{array}{llllll}0.3 & 0.4 & 0.5 & 0.6 & 0.7 & 0.8\end{array}$

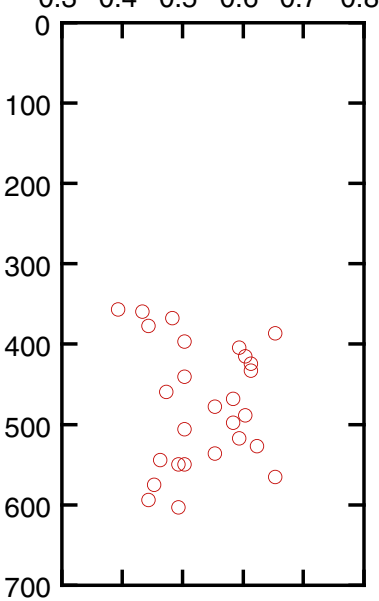

K $\quad$ Si $(\mu \mathrm{M})$

$\begin{array}{lllll}0 & 100 & 200 & 300 & 400\end{array}$

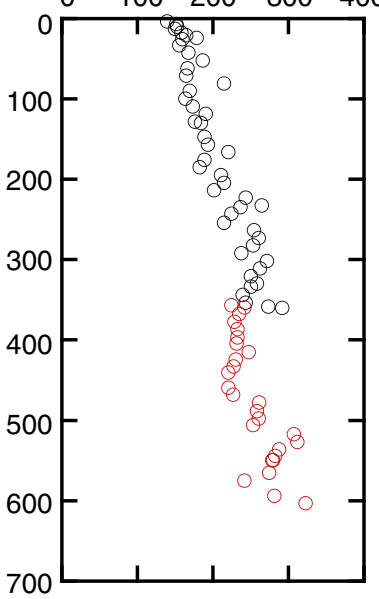

D $\mathrm{Na}(\mathrm{mM})$

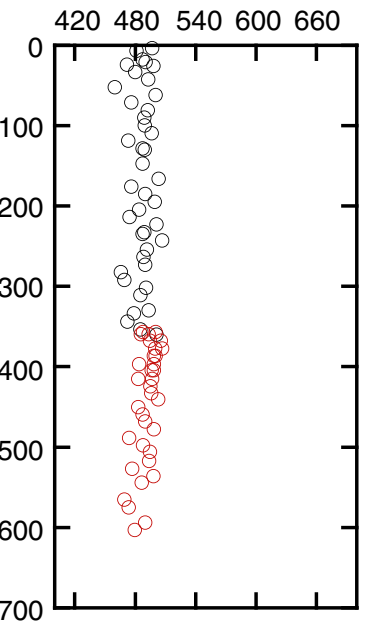

H $\mathrm{Fe}(\mu \mathrm{M})$

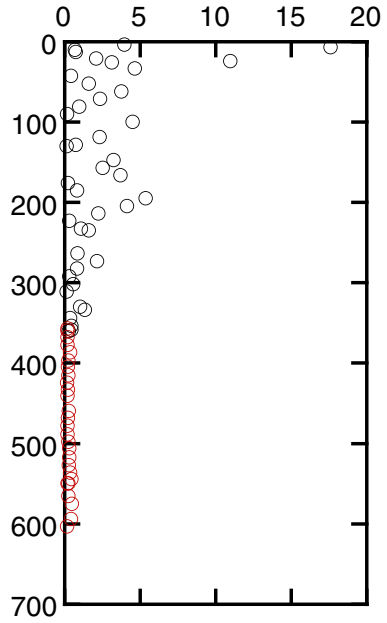

L $\quad \mathrm{Mn}(\mu \mathrm{M})$

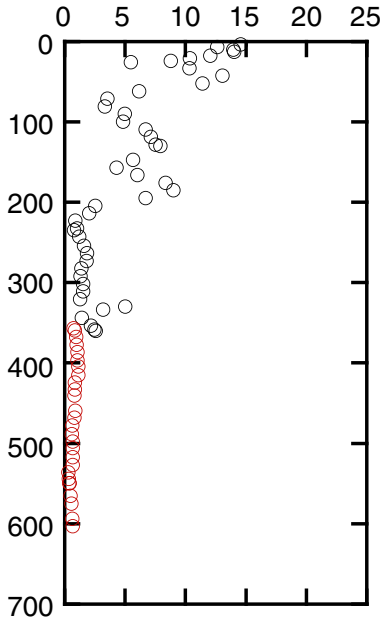

$\bigcirc$ Hole U1341A $\bigcirc$ Hole U1341B 
Figure F23. Solid-phase chemical concentrations, Holes U1341A and U1341B. A. Calcium carbonate $\left(\mathrm{CaCO}_{3}\right)$. B. Total organic carbon (TOC). C. Total nitrogen (TN). D. Total sulfur (TS).

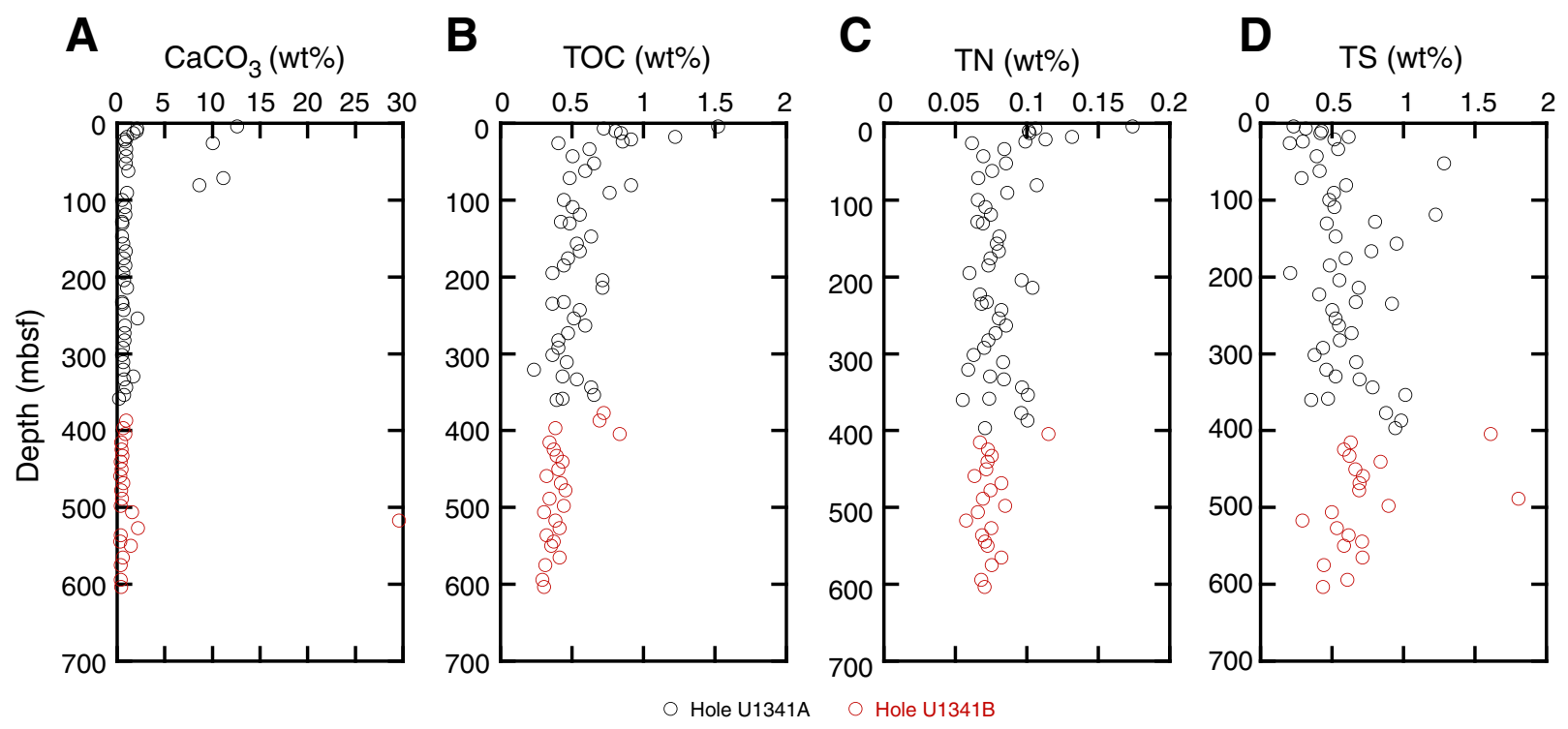


Figure F24. A. Downhole distribution of moisture and density (MAD) wet bulk density measurements on discrete samples of core sediment, Hole U1341B. (Continued on next page.)

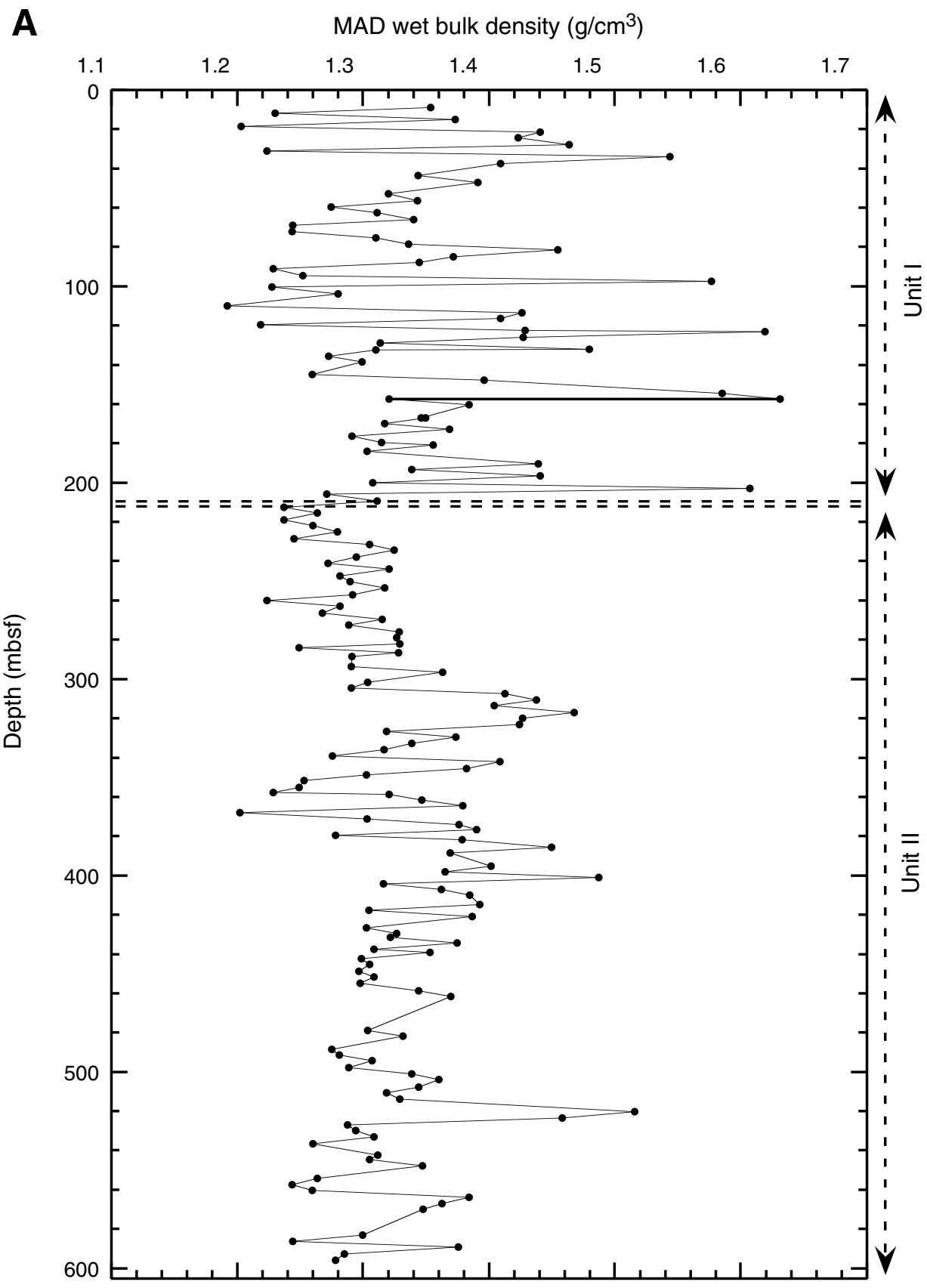


Figure F24 (continued). B. Downhole distribution of WRMSL gamma ray attenuation (GRA) wet bulk density, Hole U1341B.

B GRA bulk density $\left(\mathrm{g} / \mathrm{cm}^{3}\right)$

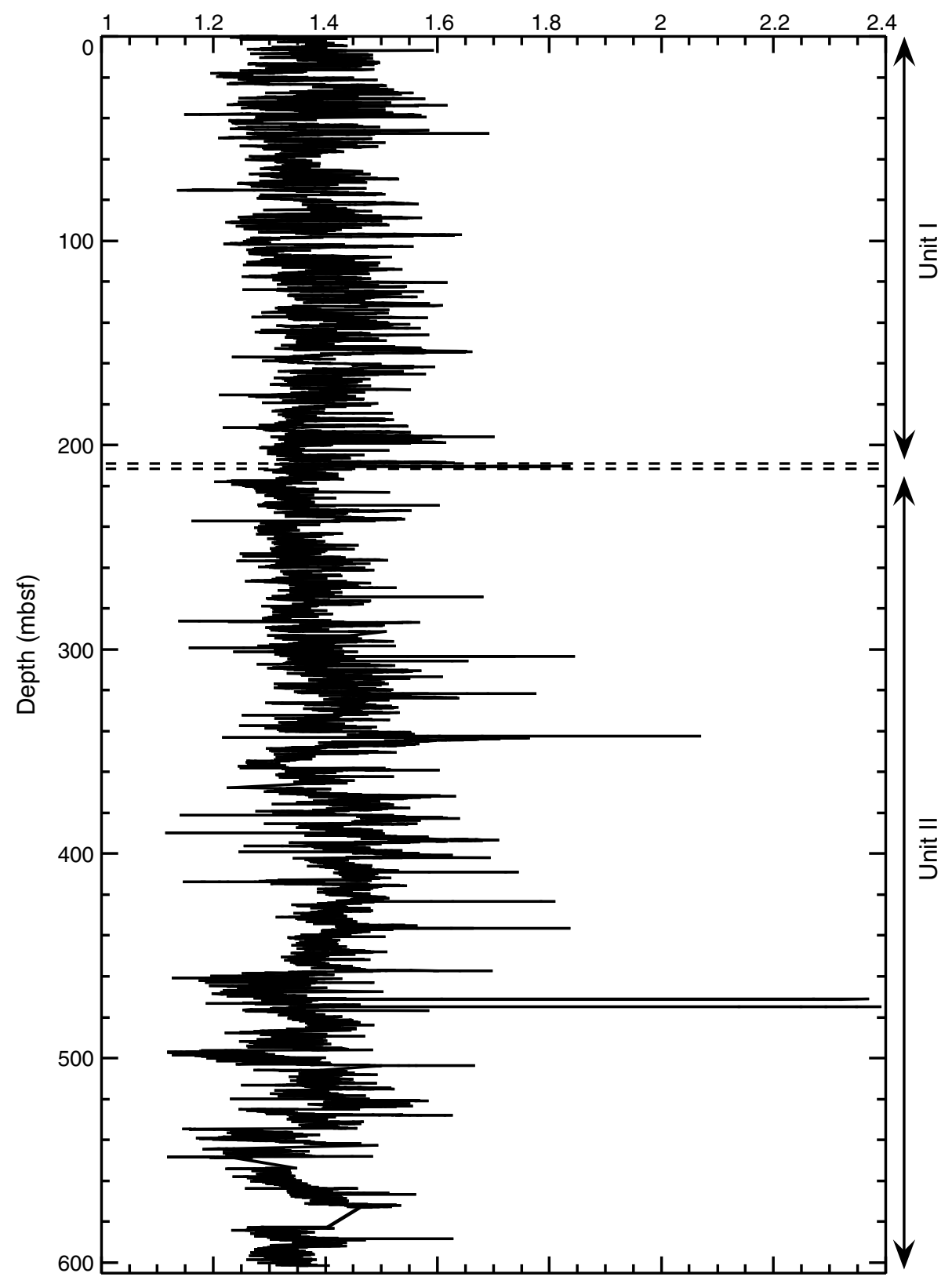


Figure F25. Downhole distribution of magnetic susceptibility, Hole U1341B.

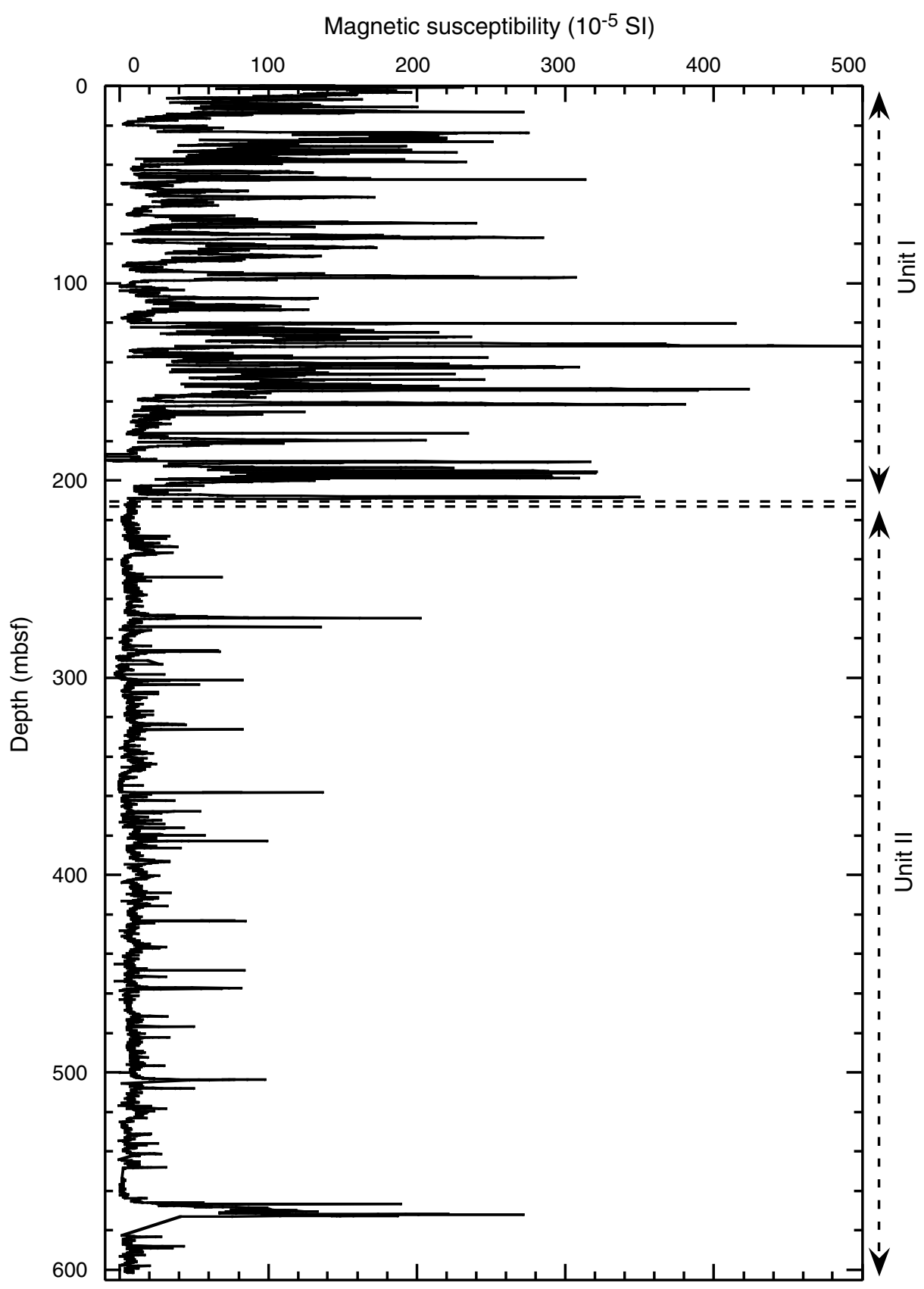


Figure F26. Downhole distribution of natural gamma radiation (NGR), Hole U1341B.

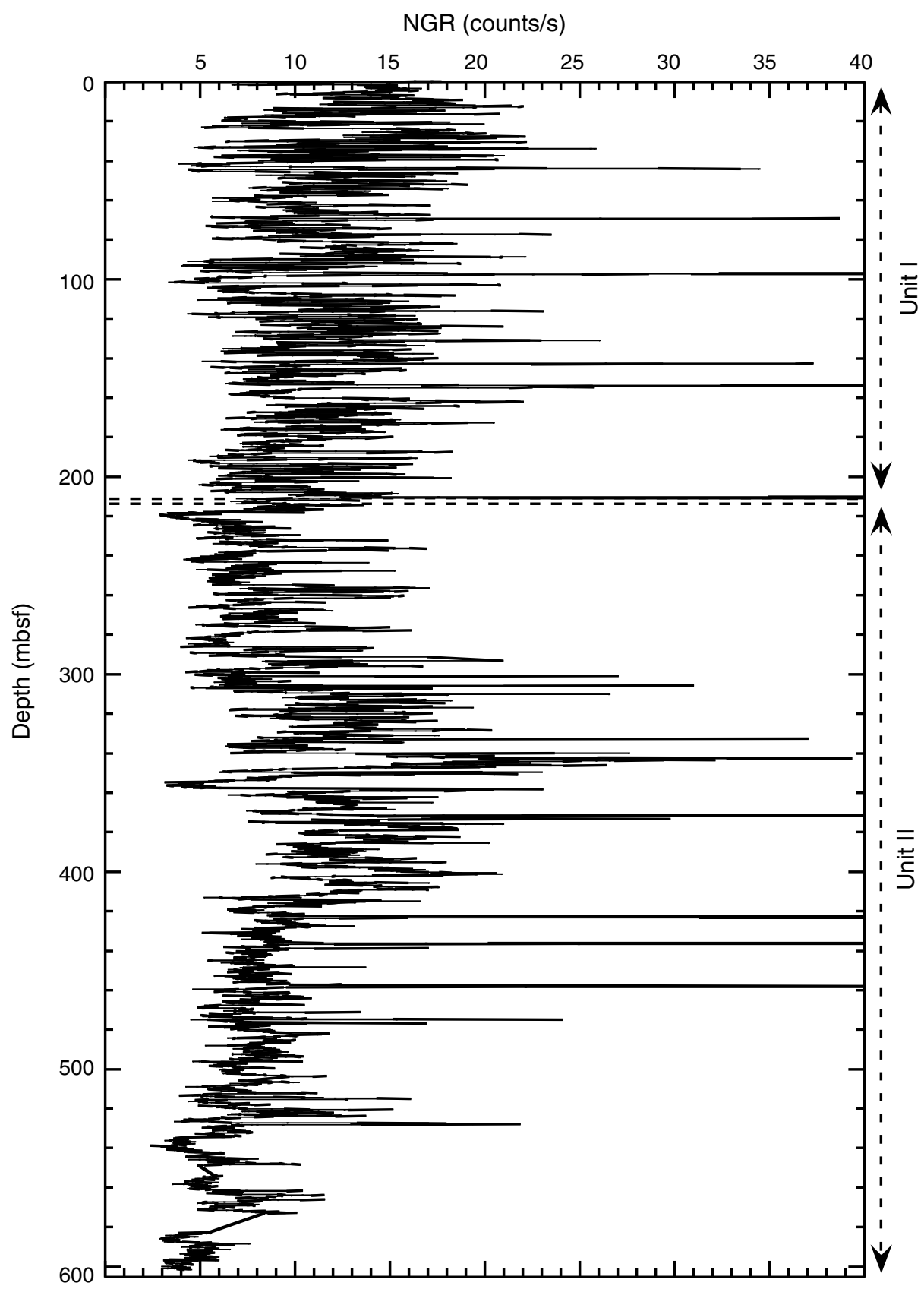


Figure F27. Downhole distribution of $P$-wave velocity recorded by the Whole-Round Multisensor Logger, Hole U1341B.

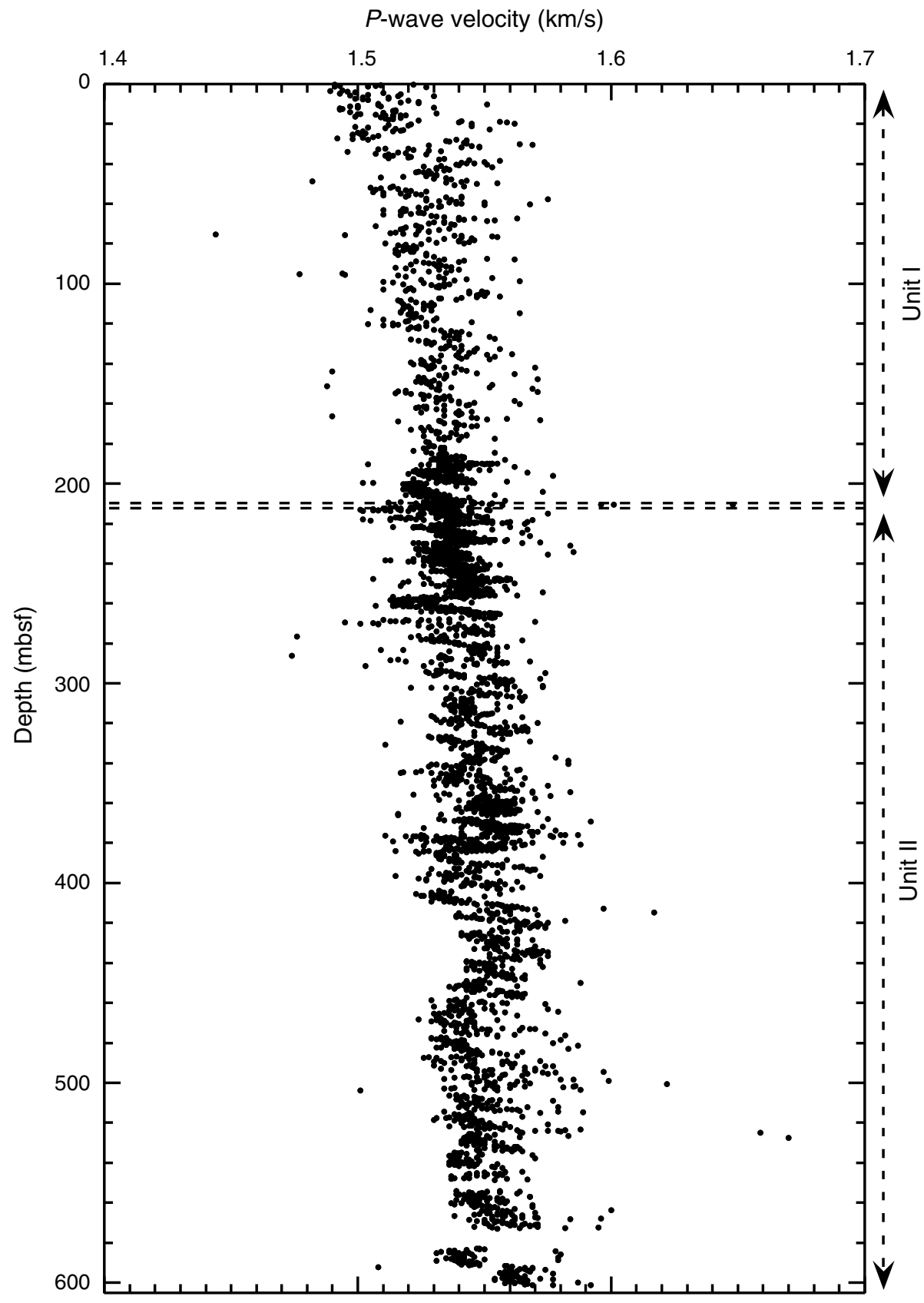


Figure F28. Downhole distribution of sediment water content (percent of total sediment weight) and porosity, Hole U1341B.

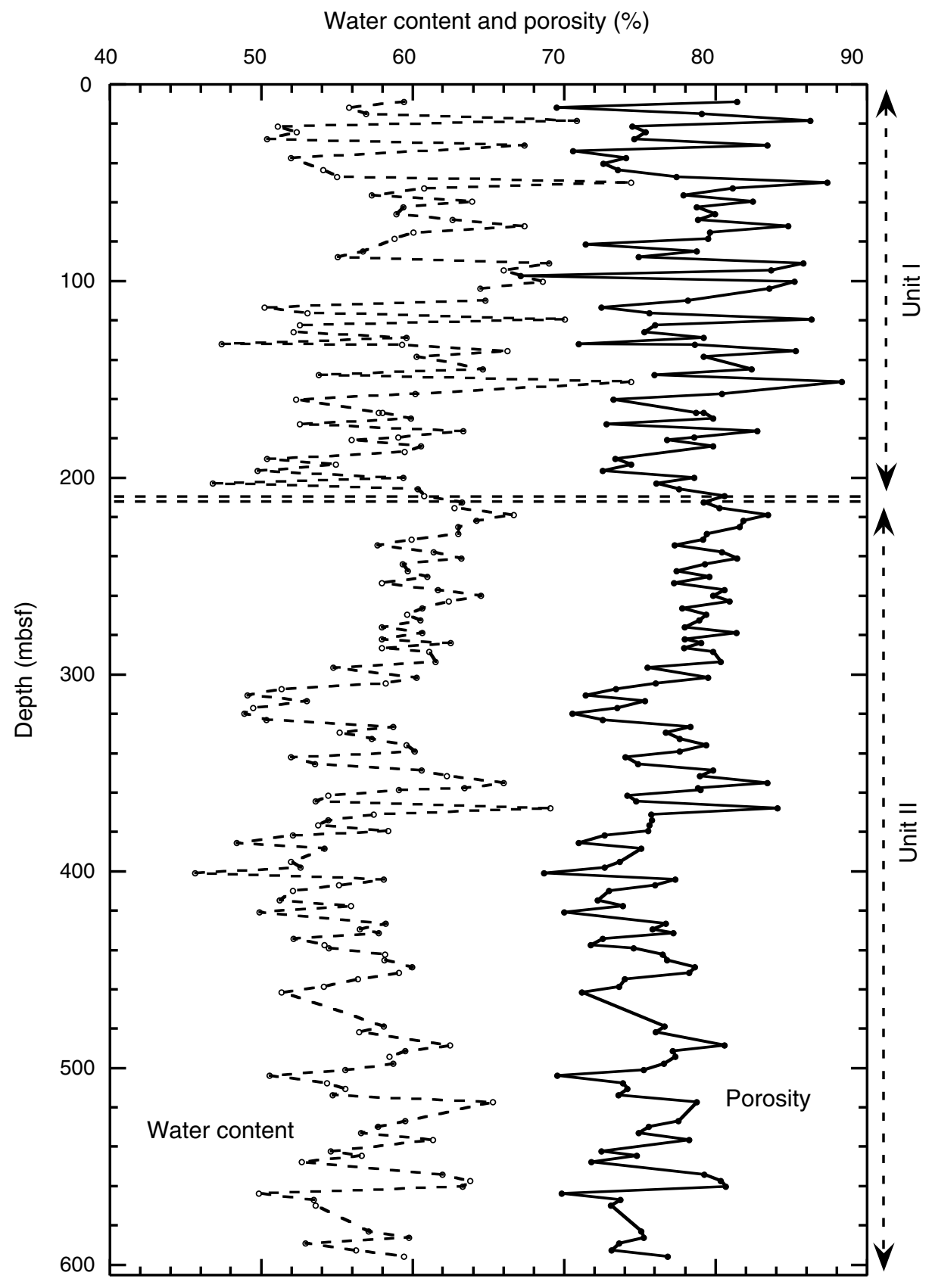


Figure F29. Downhole profile of grain density, Hole U1341B, measured on discrete samples with the moisture and density system.

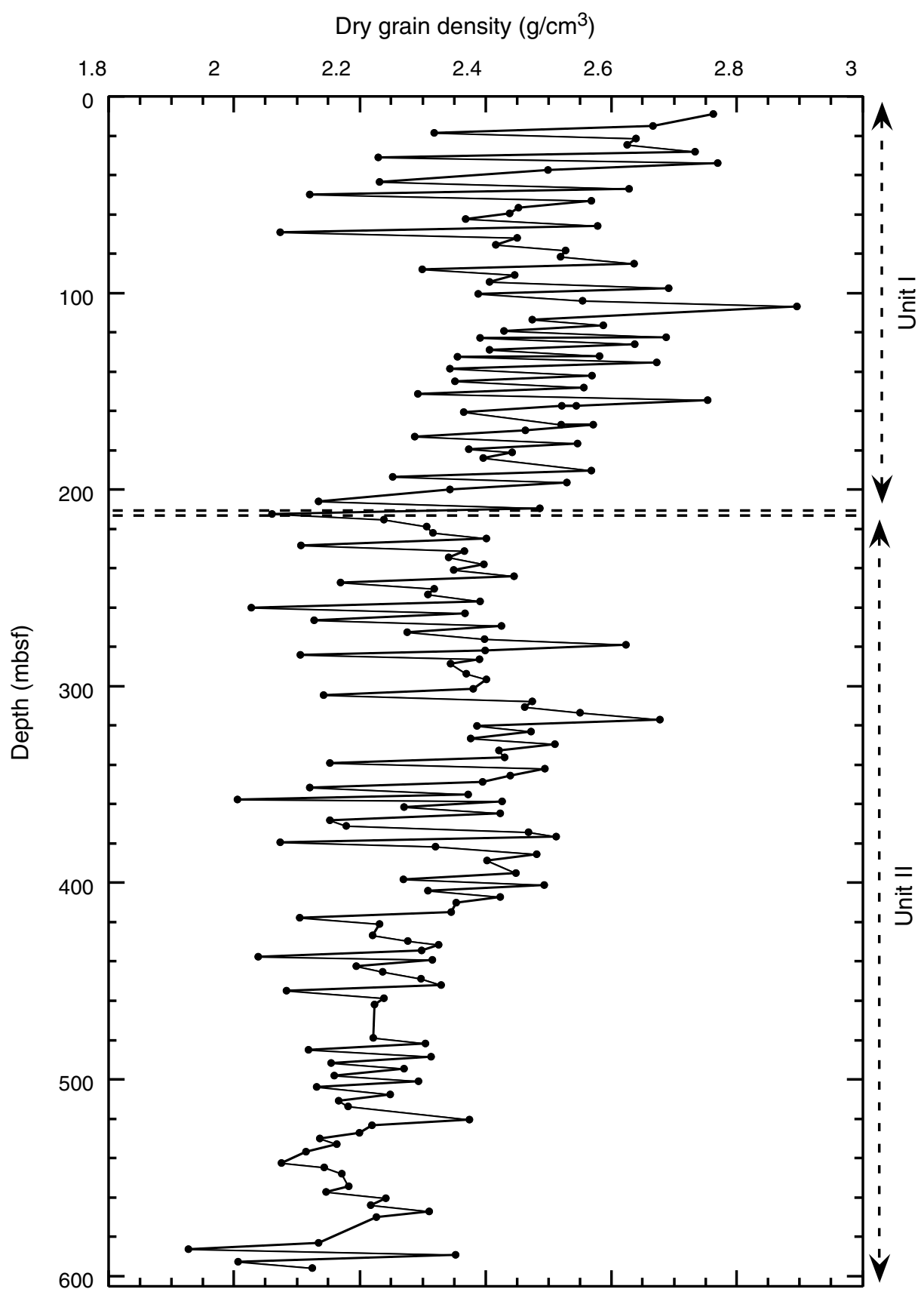


Figure F30. Downhole distribution of thermal conductivity, Hole U1341B.

Thermal conductivity $(\mathrm{W} /[\mathrm{m} \cdot \mathrm{K}])$

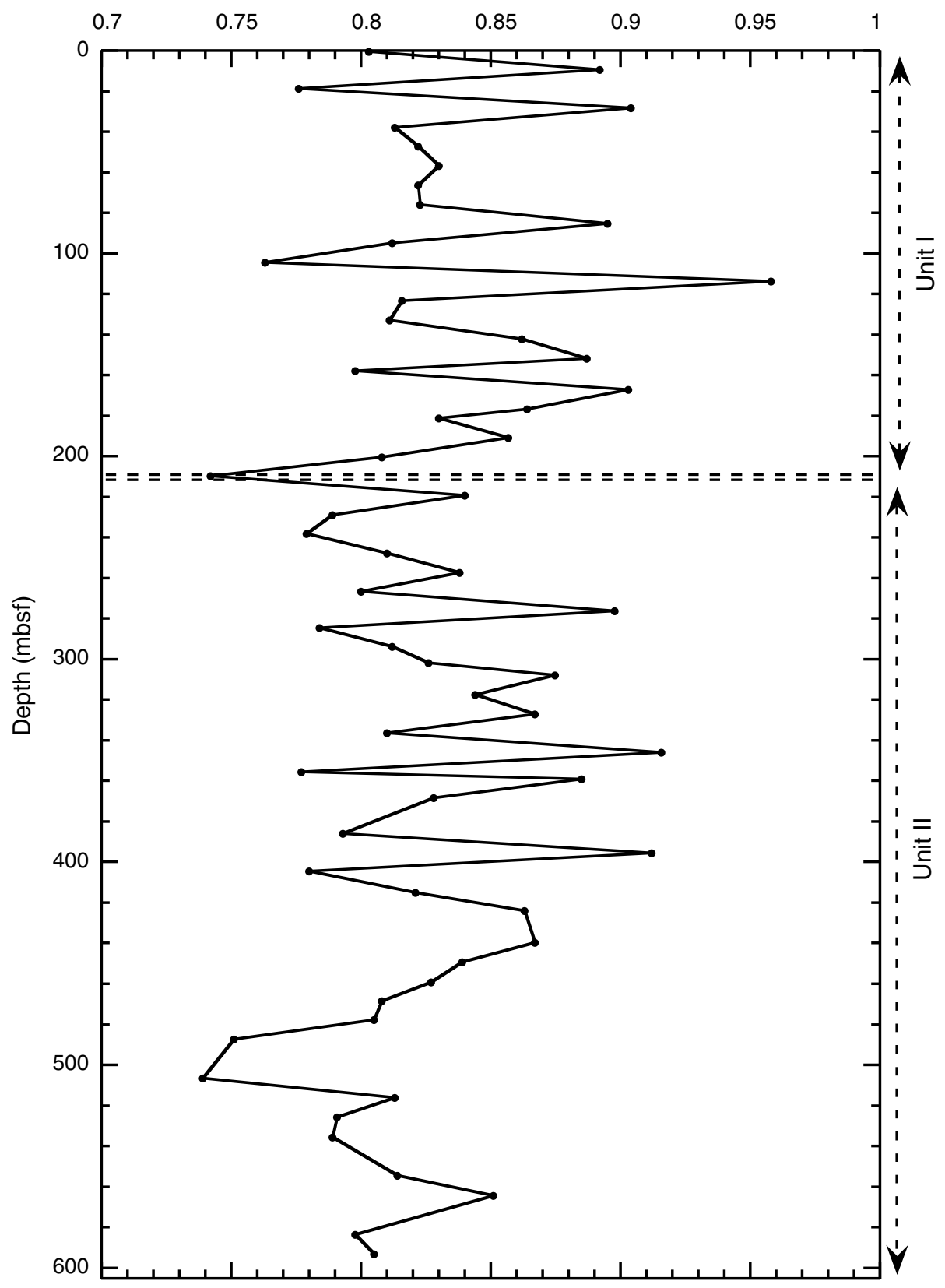


Figure F31. WRMSL magnetic susceptibility data vs. composite depth, Site U1341. For the splice record (top panel), depth on the CCSF-D scale is equivalent to depth on the CCSF-A scale. A. 0-100 m CCSF-A. (Continued on next three pages.)

A
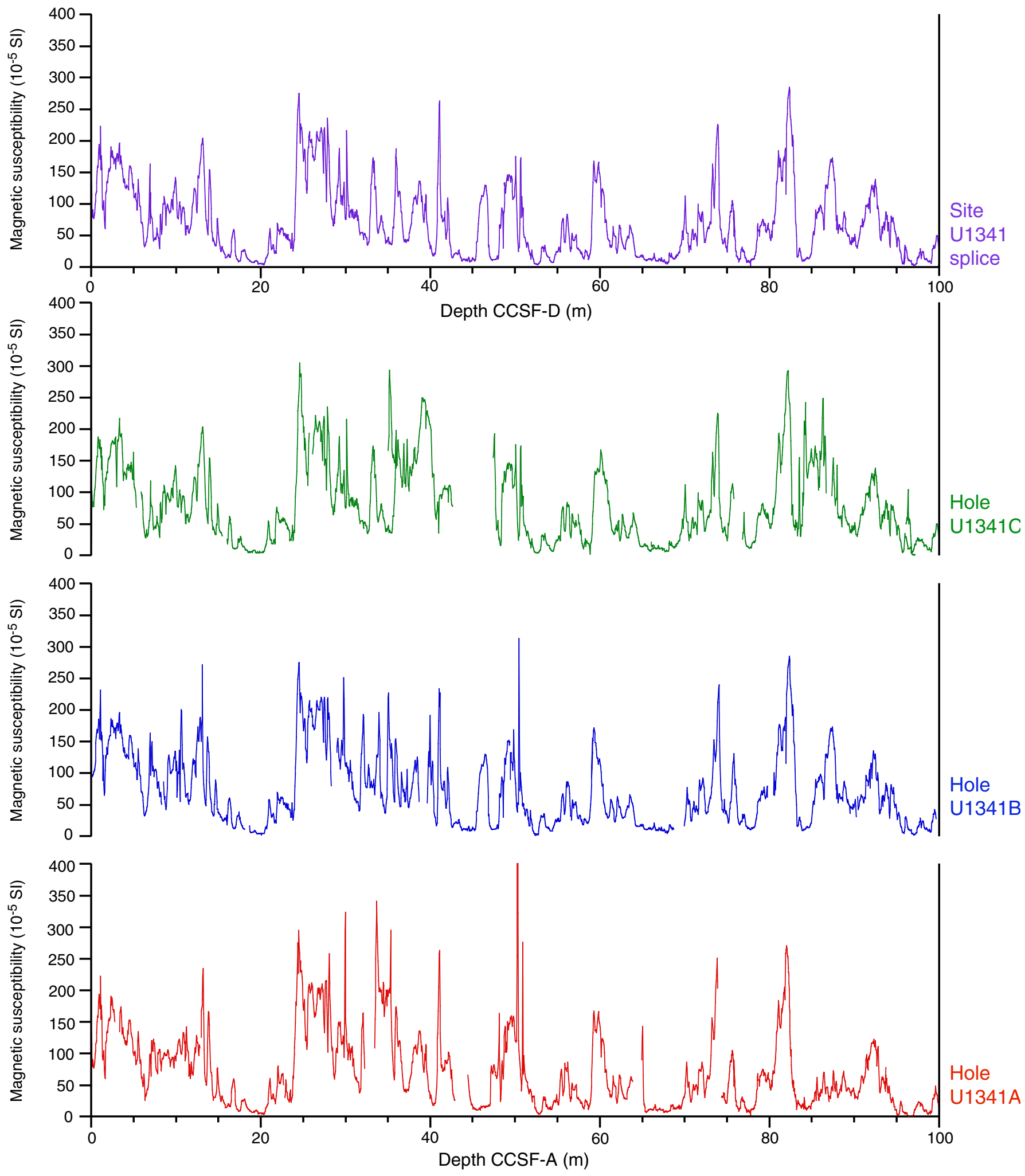
Figure F31 (continued). B. 100-200 m CCSF-A. (Continued on next page.)

\section{B}
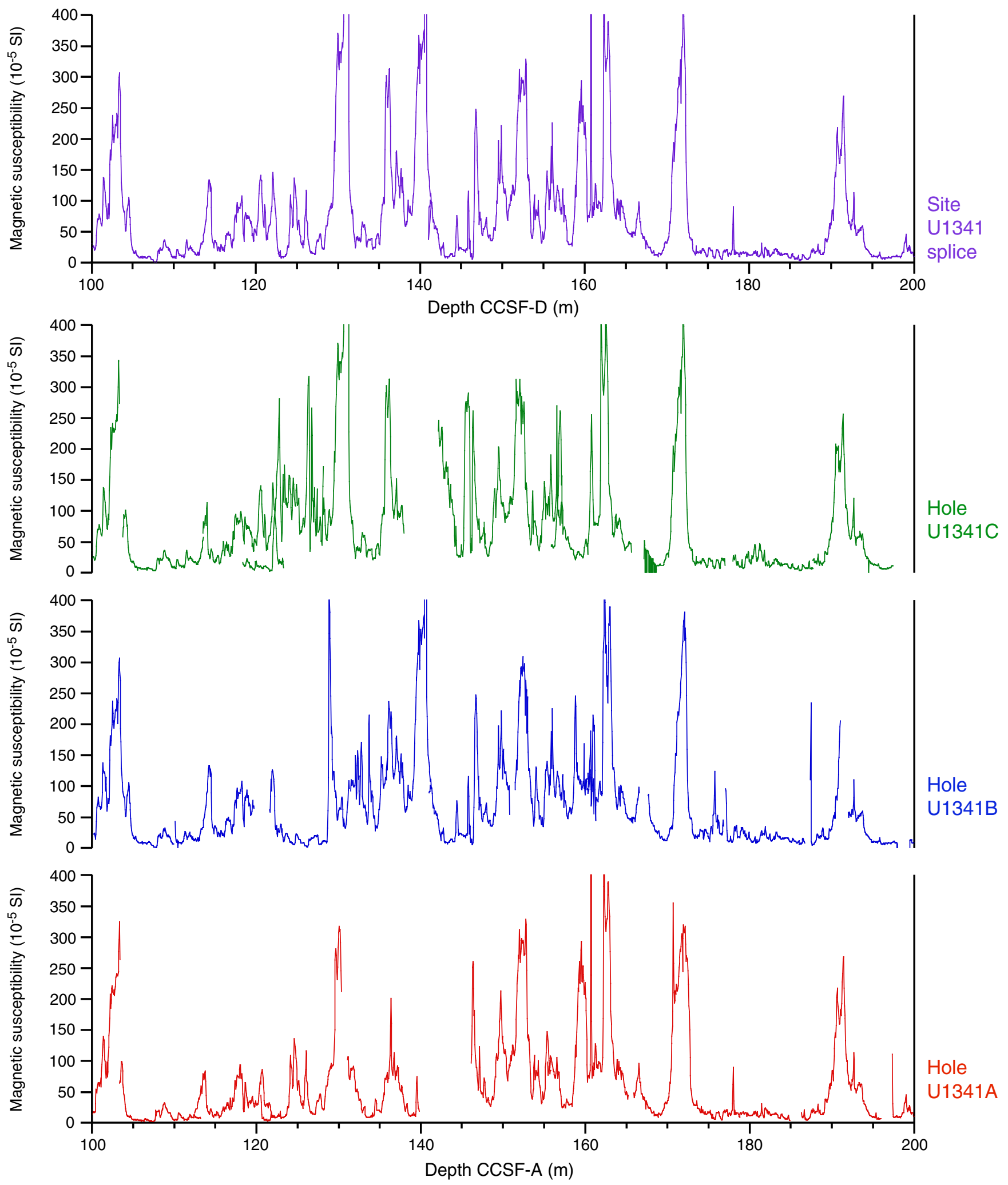
Figure F31 (continued). C. 200-300 m CCSF-A. (Continued on next page.)
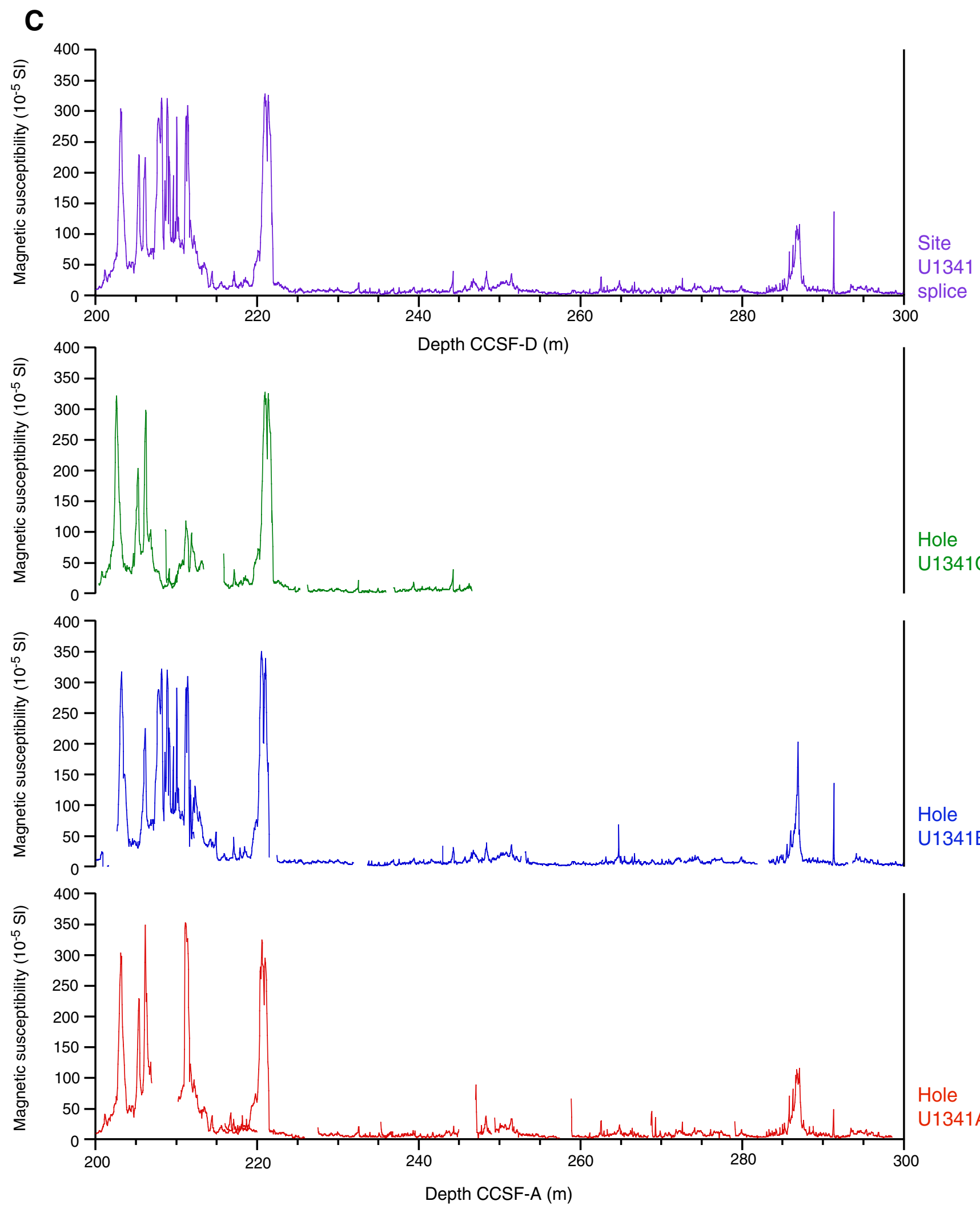
Figure F31 (continued). D. 300-400 m CCSF-A.
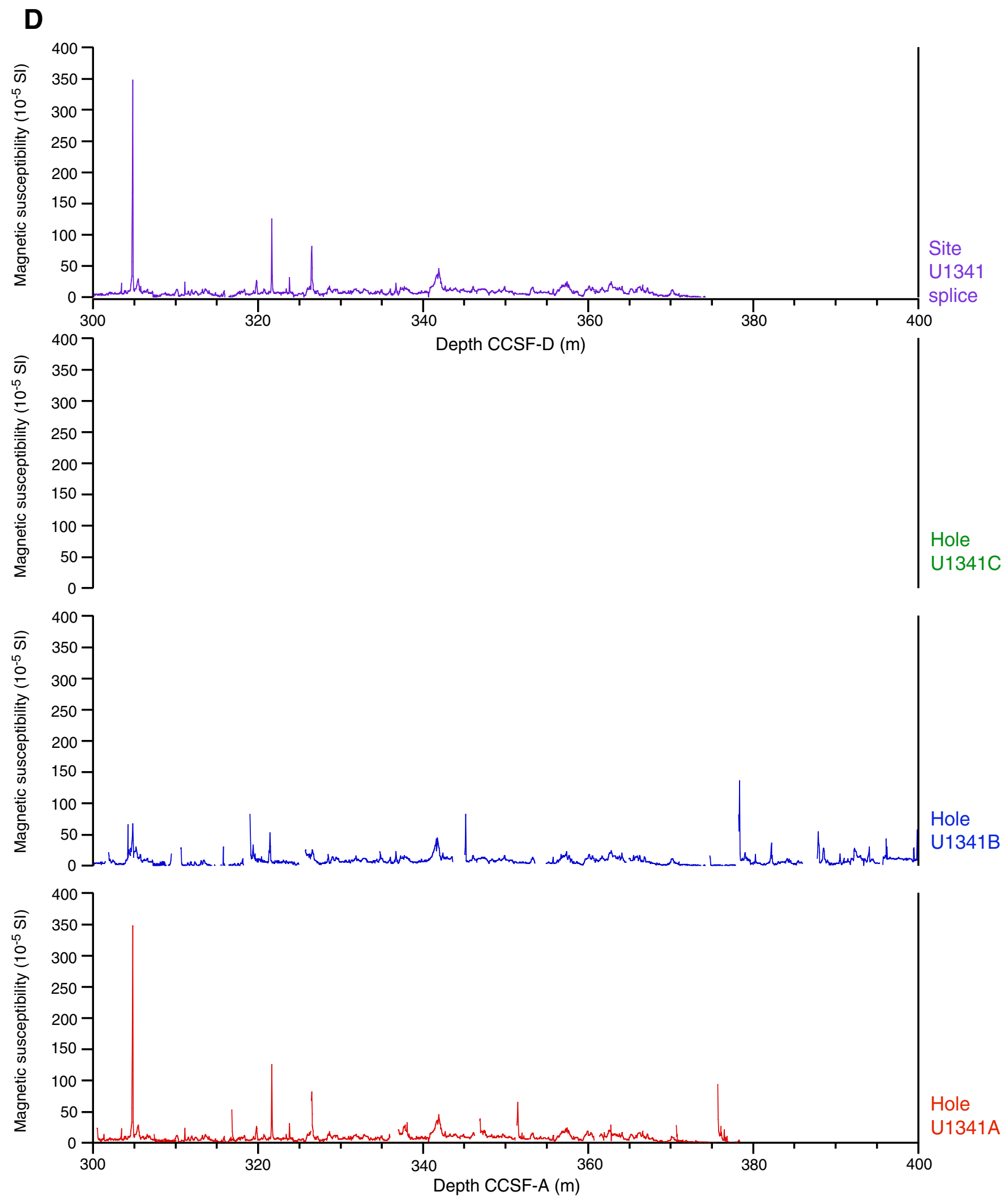
Figure F32. Natural gamma ray (NGR) data collected with the Natural Gamma Radiation Logger vs. composite depth, Site U1341. For the splice record (top panel), depth on the CCSF-D scale is equivalent to depth on the CCSF-A scale. A. 0-100 m CCSF-A. (Continued on next three pages.)

A
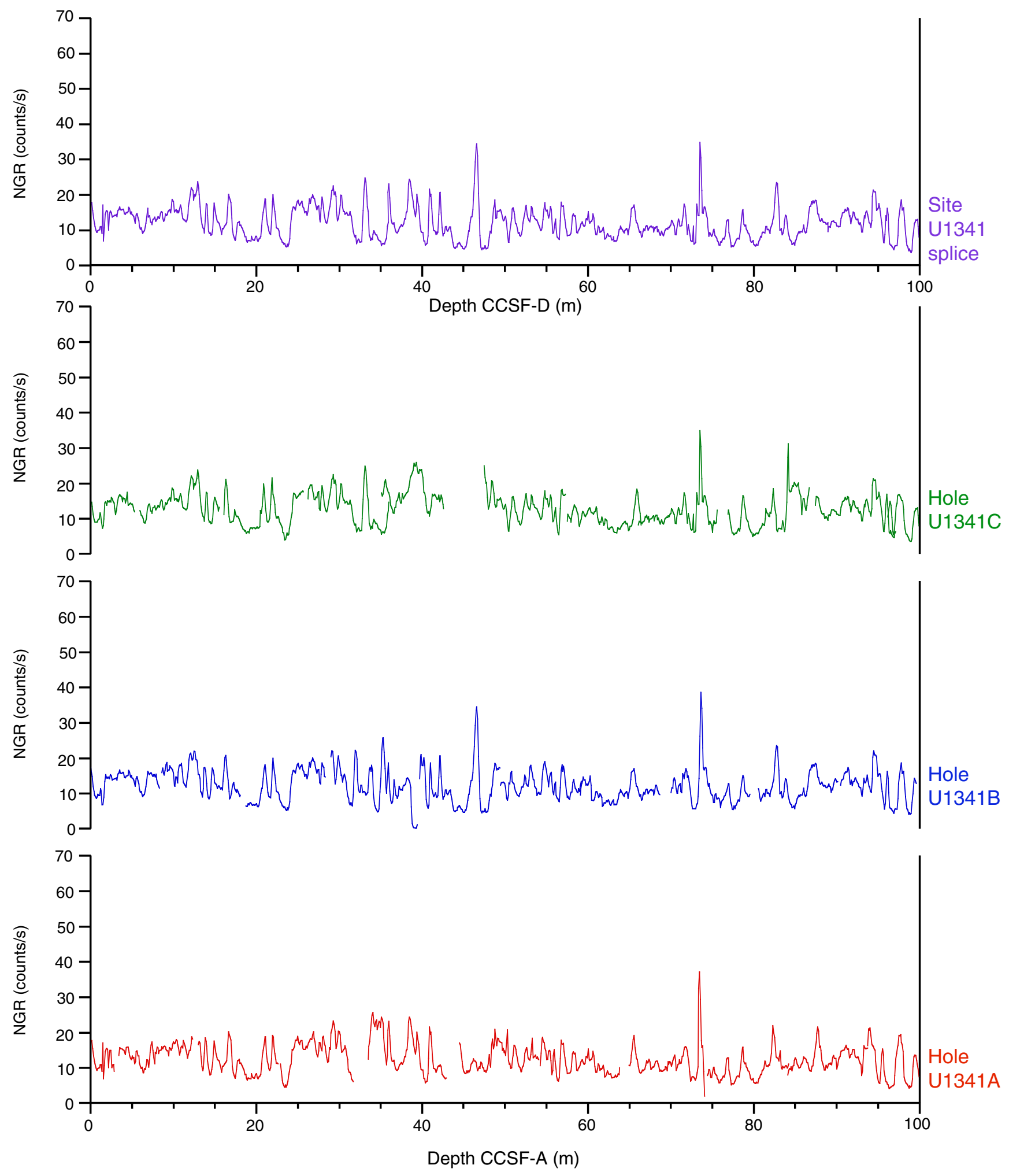
Figure F32 (continued). B. 100-200 m CCSF-A. (Continued on next page.)

B
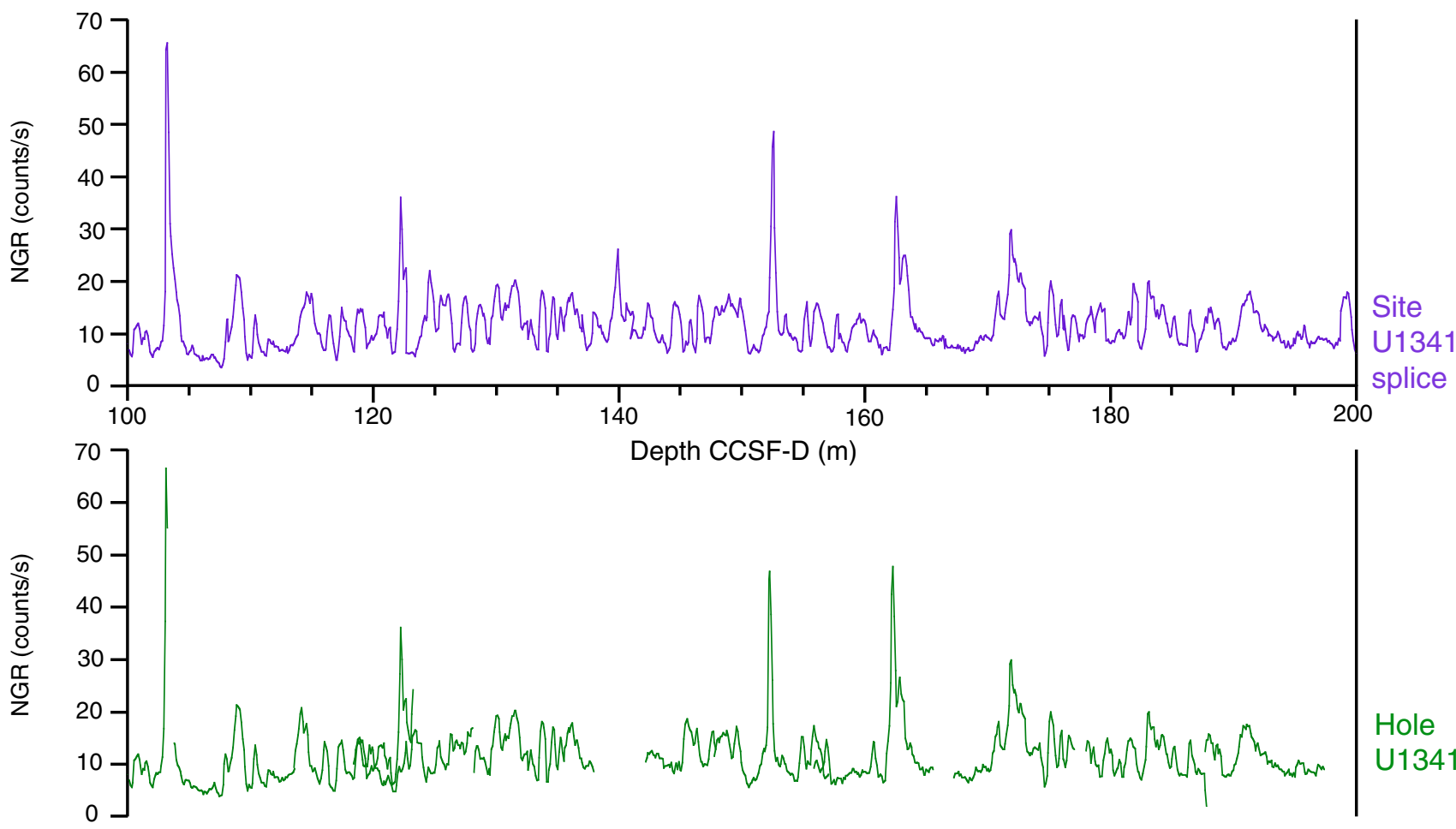

Depth CCSF-D (m)
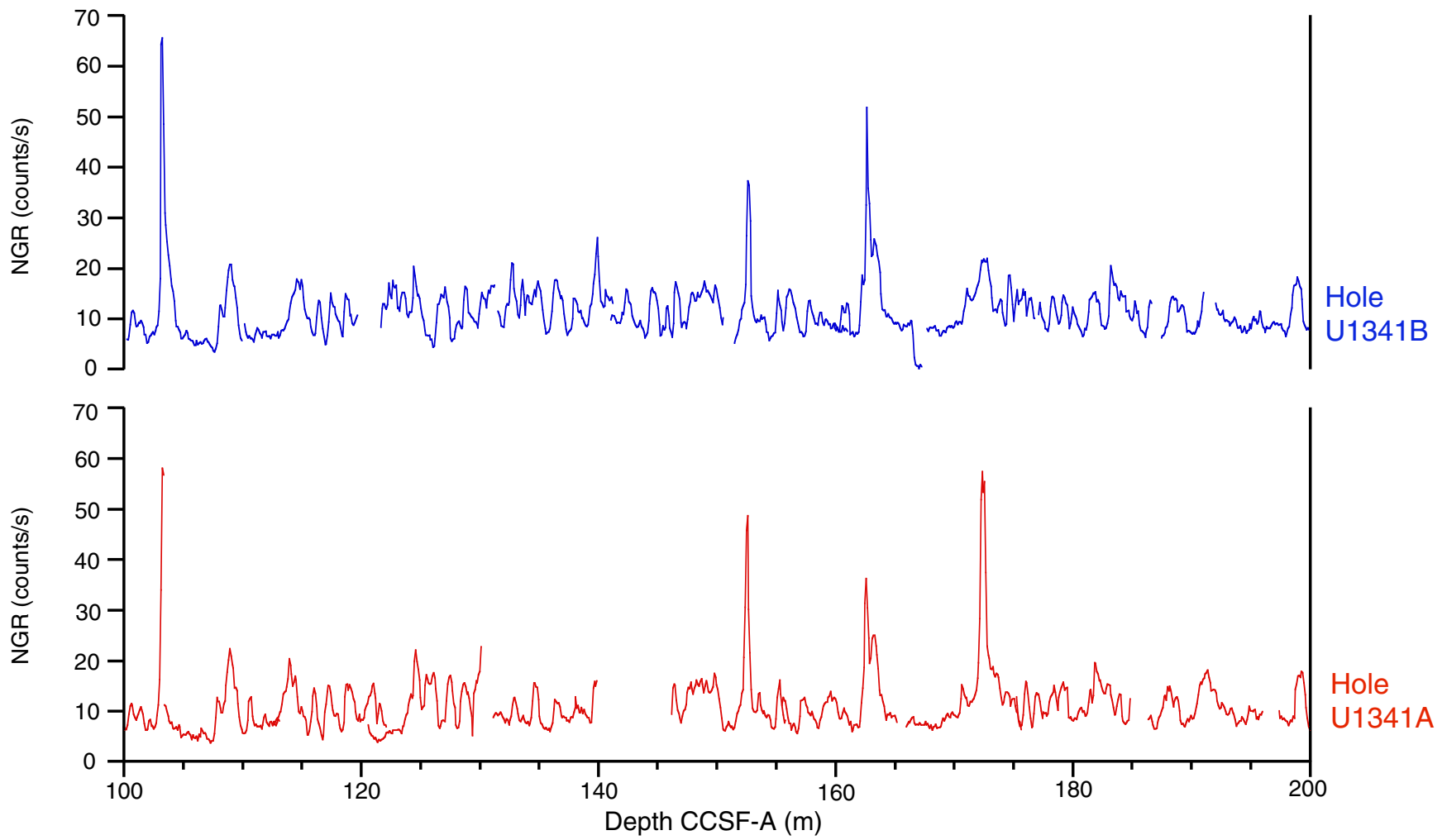
Figure F32 (continued). C. 200-300 m CCSF-A. (Continued on next page.)

\section{C}
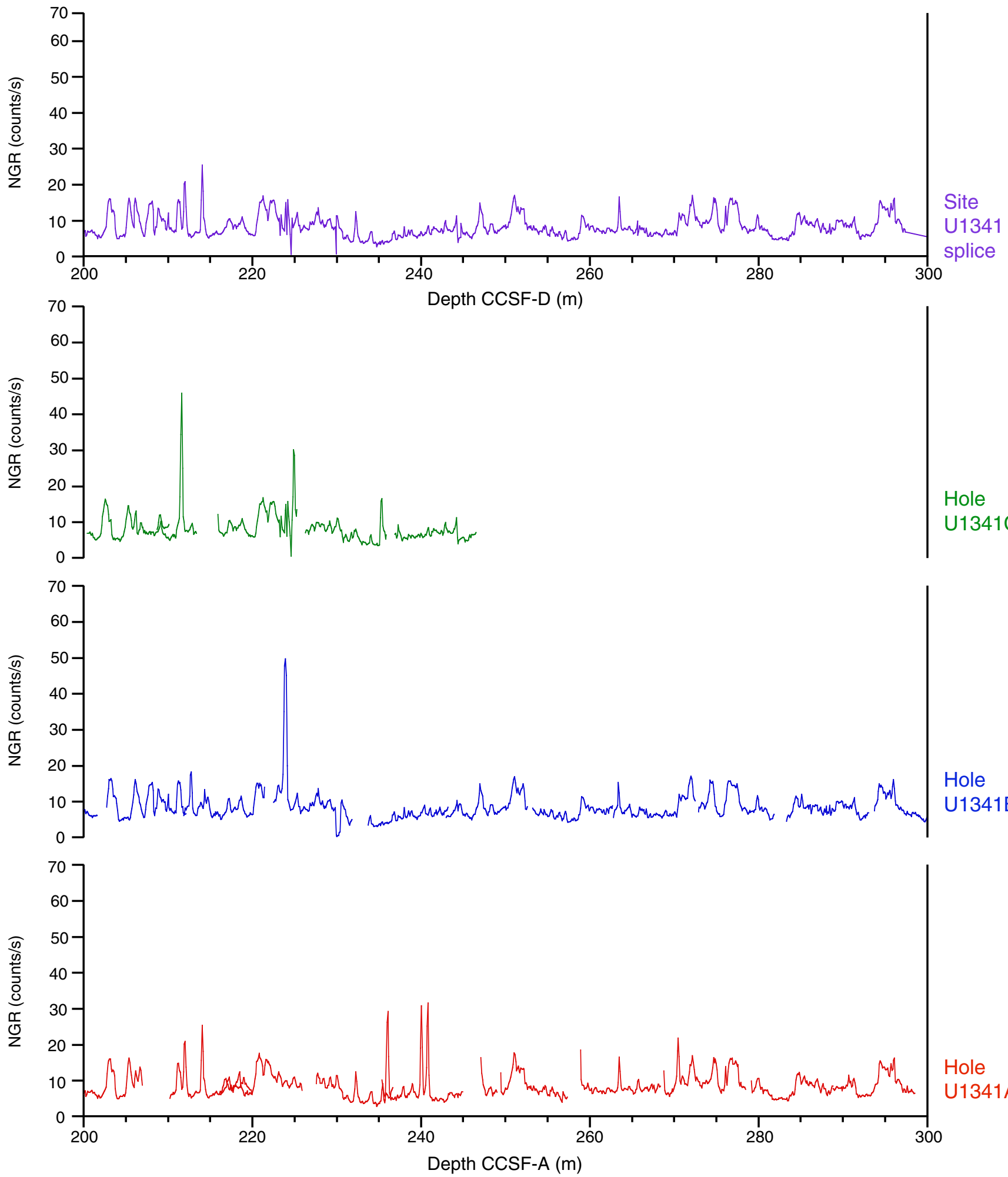
Figure F32 (continued). D. 300-400 m CCSF-A.
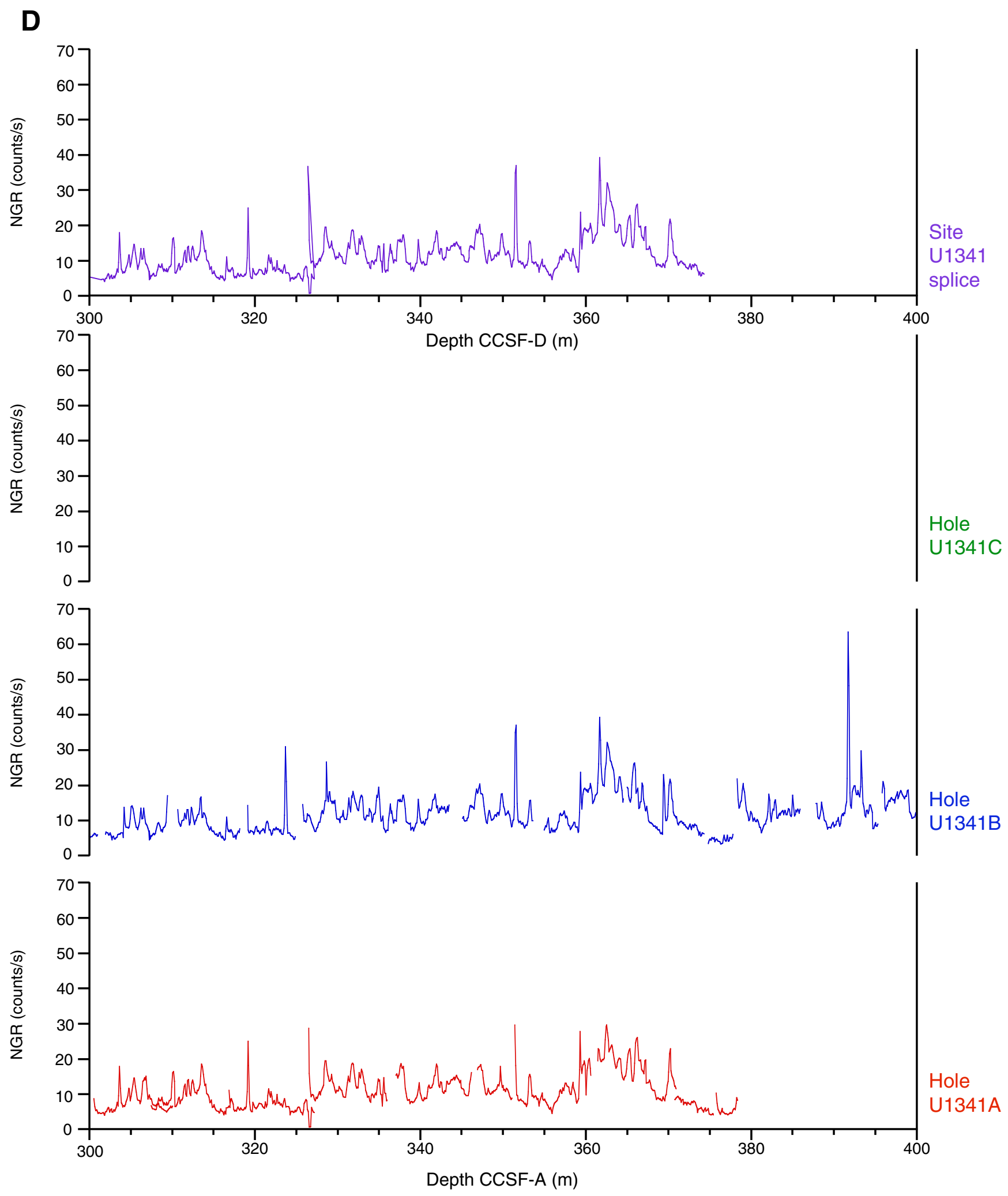
Figure F33. WRMSL gamma ray attenuation (GRA) bulk density vs. composite depth, Site U1341. For the splice record (top panel), depth on the CCSF-D scale is equivalent to depth on the CCSF-A scale. A. 0-100 m CCSF-A. (Continued on next three pages.)
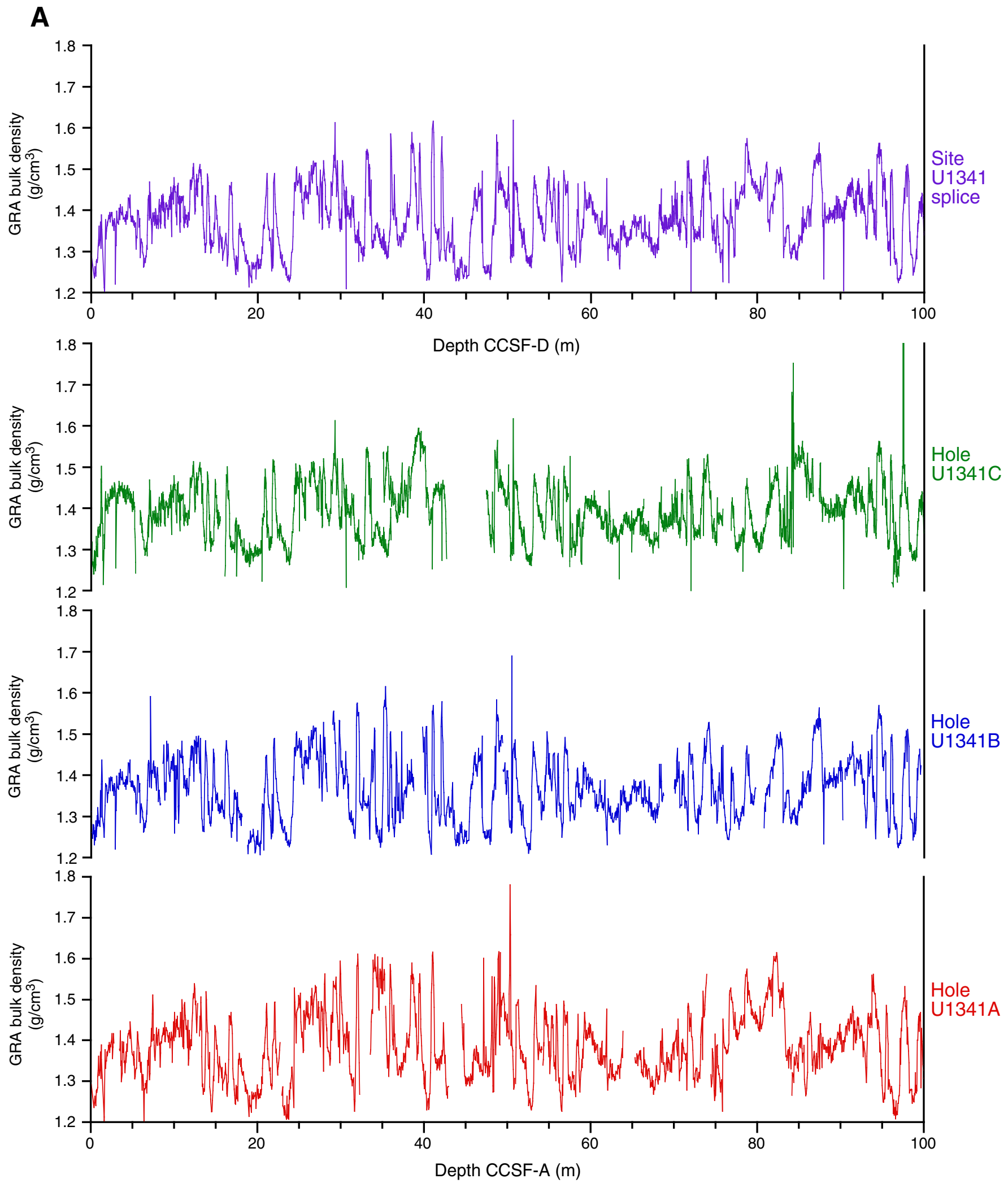
Figure F33 (continued). B. 100-200 m CCSF-A. (Continued on next page.)

B
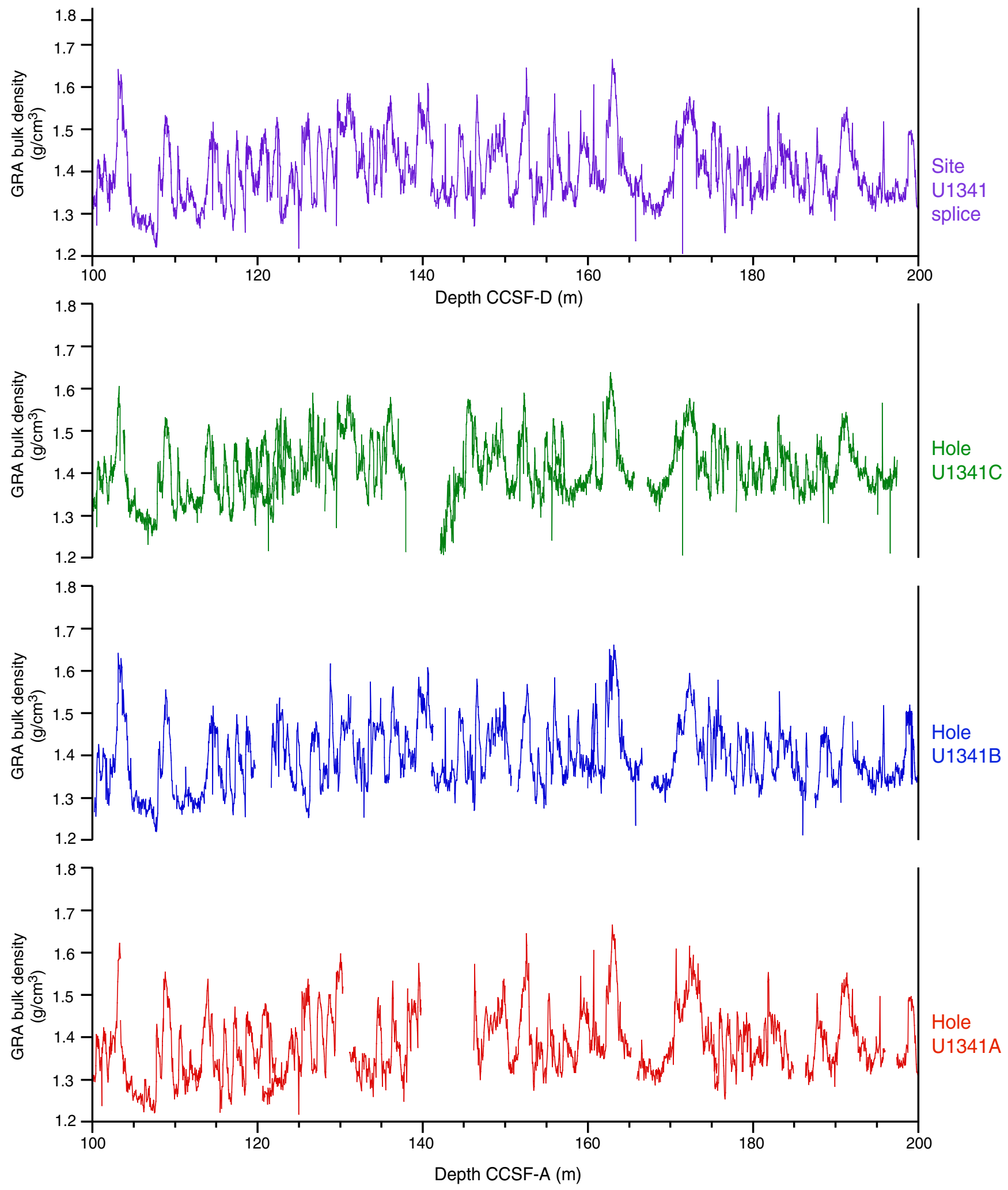
Figure F33 (continued). C. 200-300 m CCSF-A. (Continued on next page.)

\section{C}
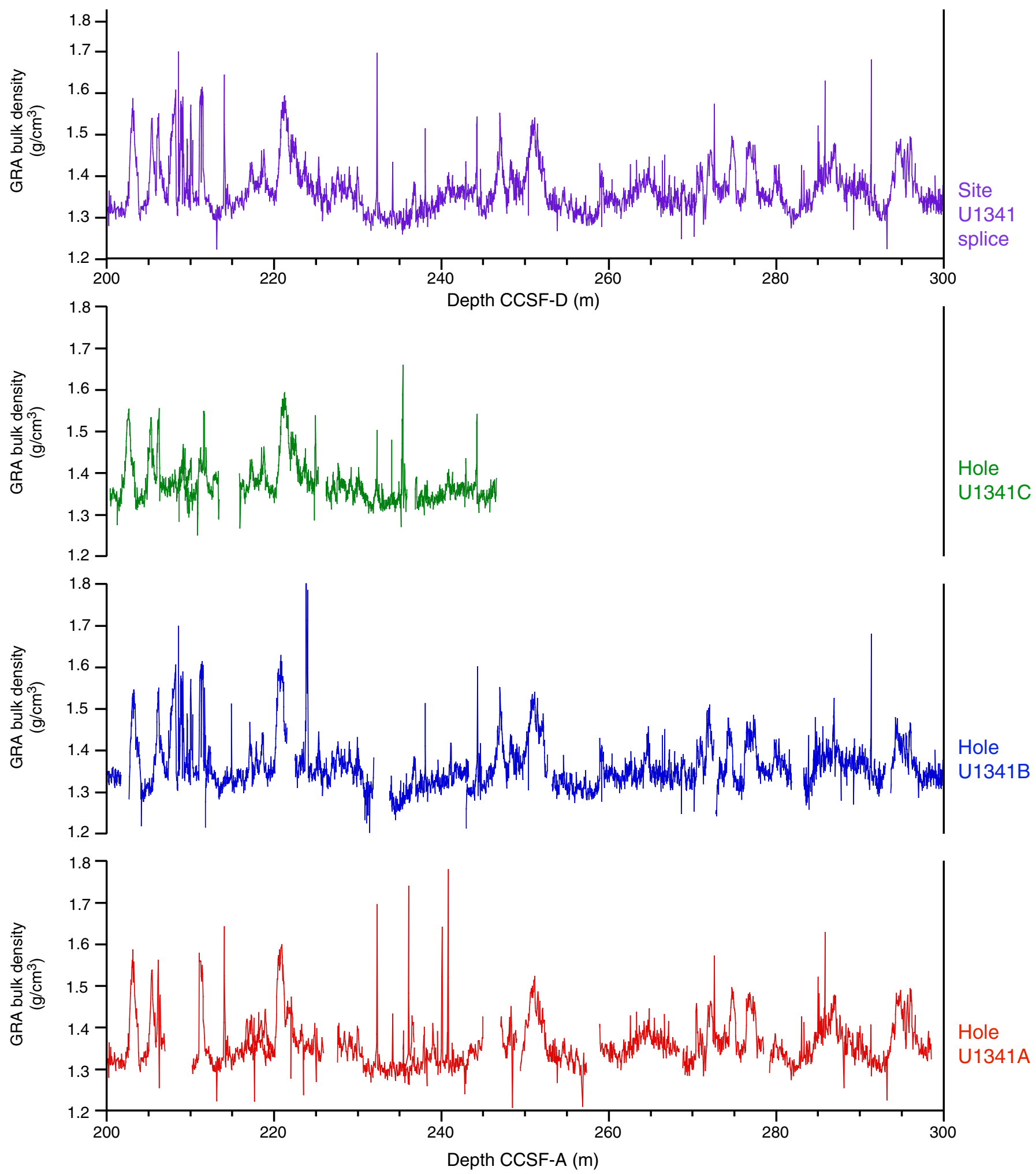
Figure F33 (continued). D. 300-400 m CCSF-A.

D

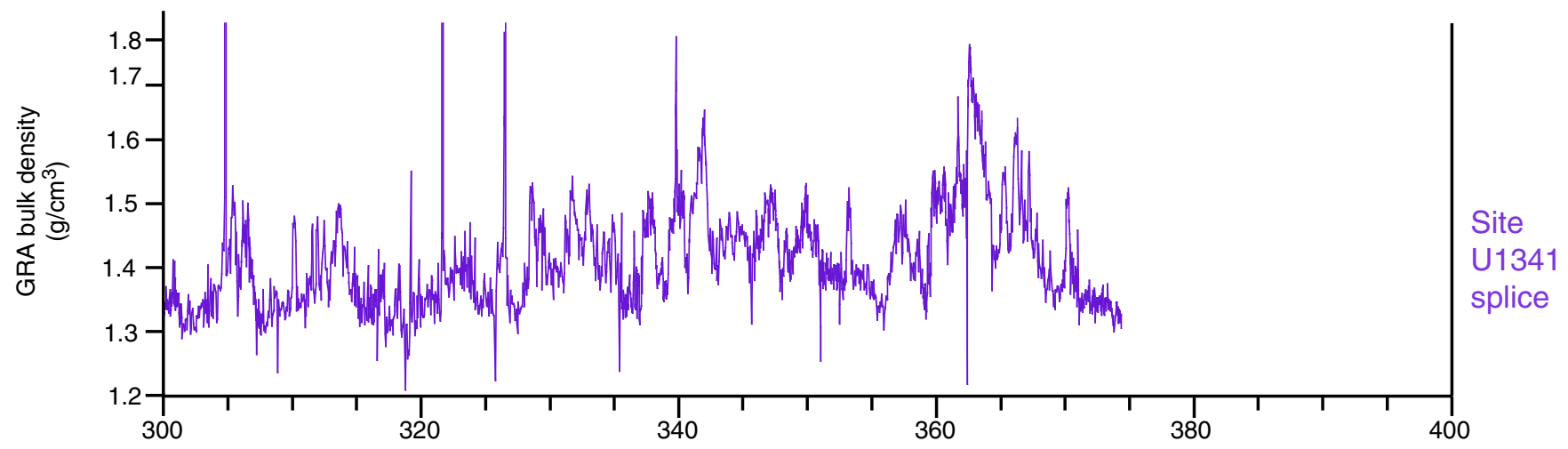

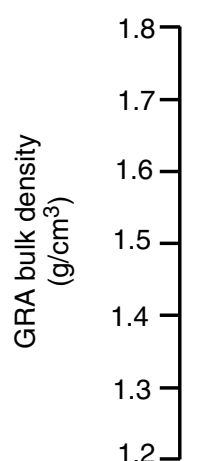

Hole
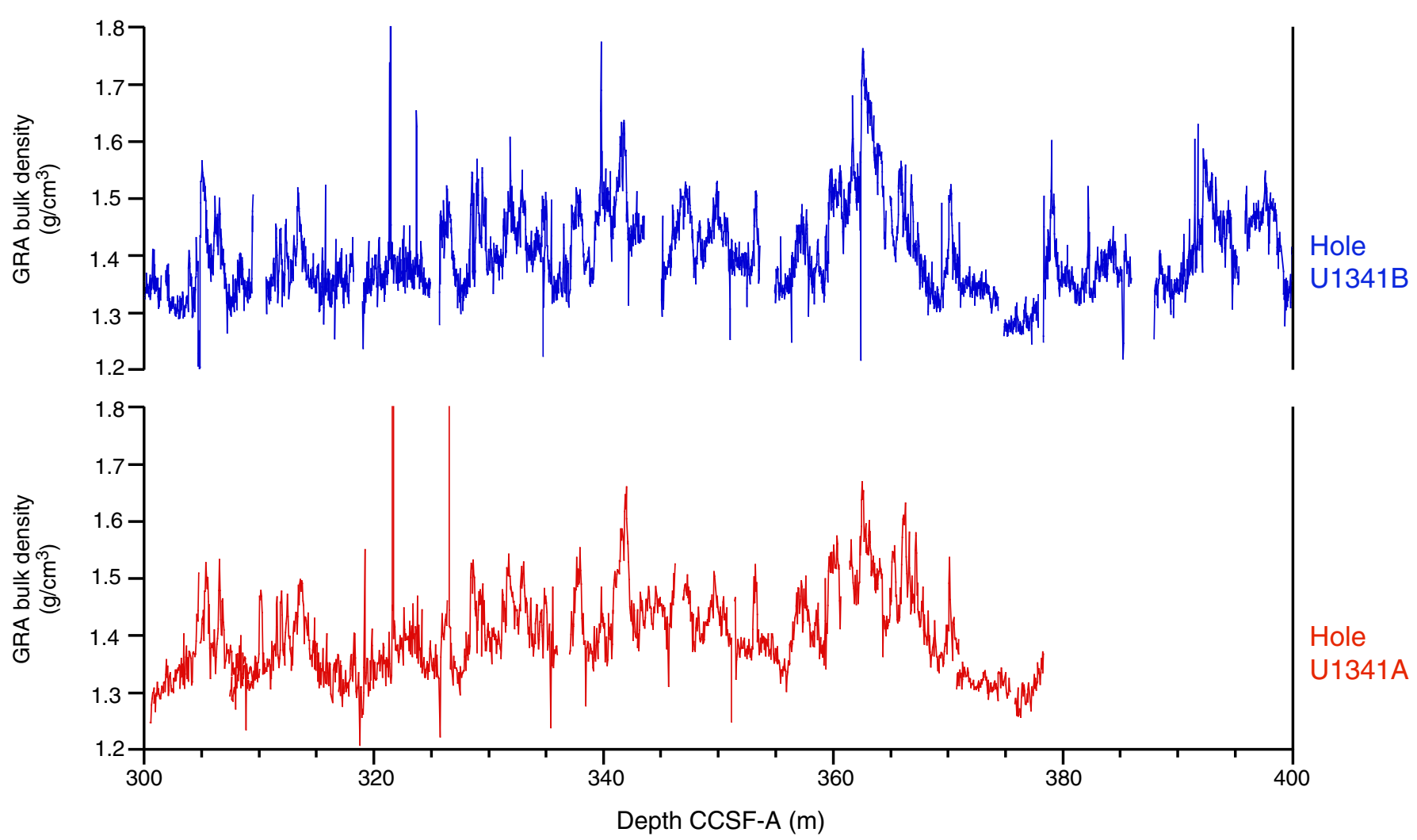
Figure F34. Spliced composite records of magnetic susceptibility, gamma ray attenuation (GRA) bulk density, and natural gamma radiation (NGR) collected on whole-round cores, Site U1341.
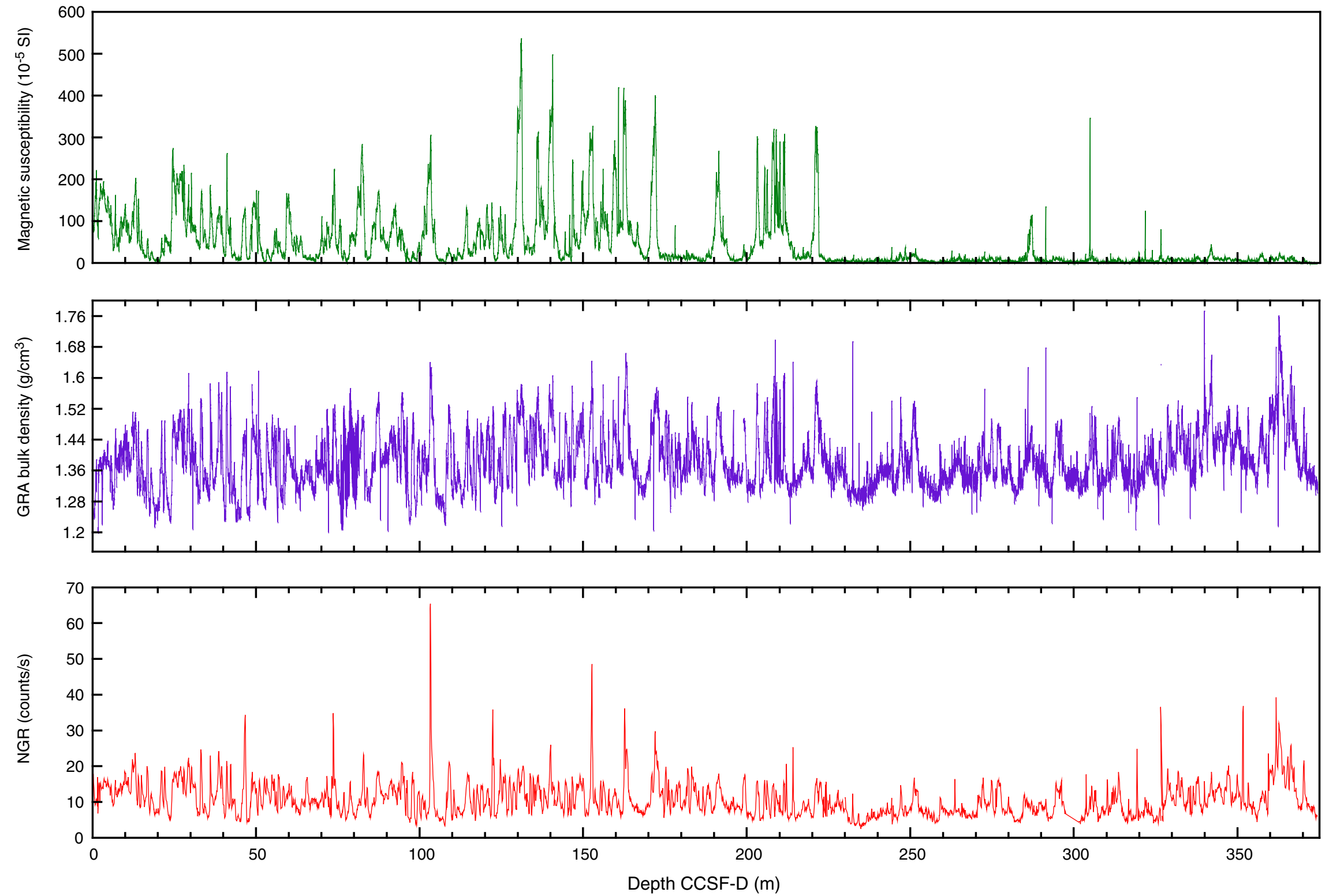
Figure F35. A. Mbsf vs. composite (CCSF-A) depth in the splice, Site U1341. B. Growth of cumulative depth offset $(\mathrm{m})$ vs. mbsf in the splice. The affine growth factor is 1.06.
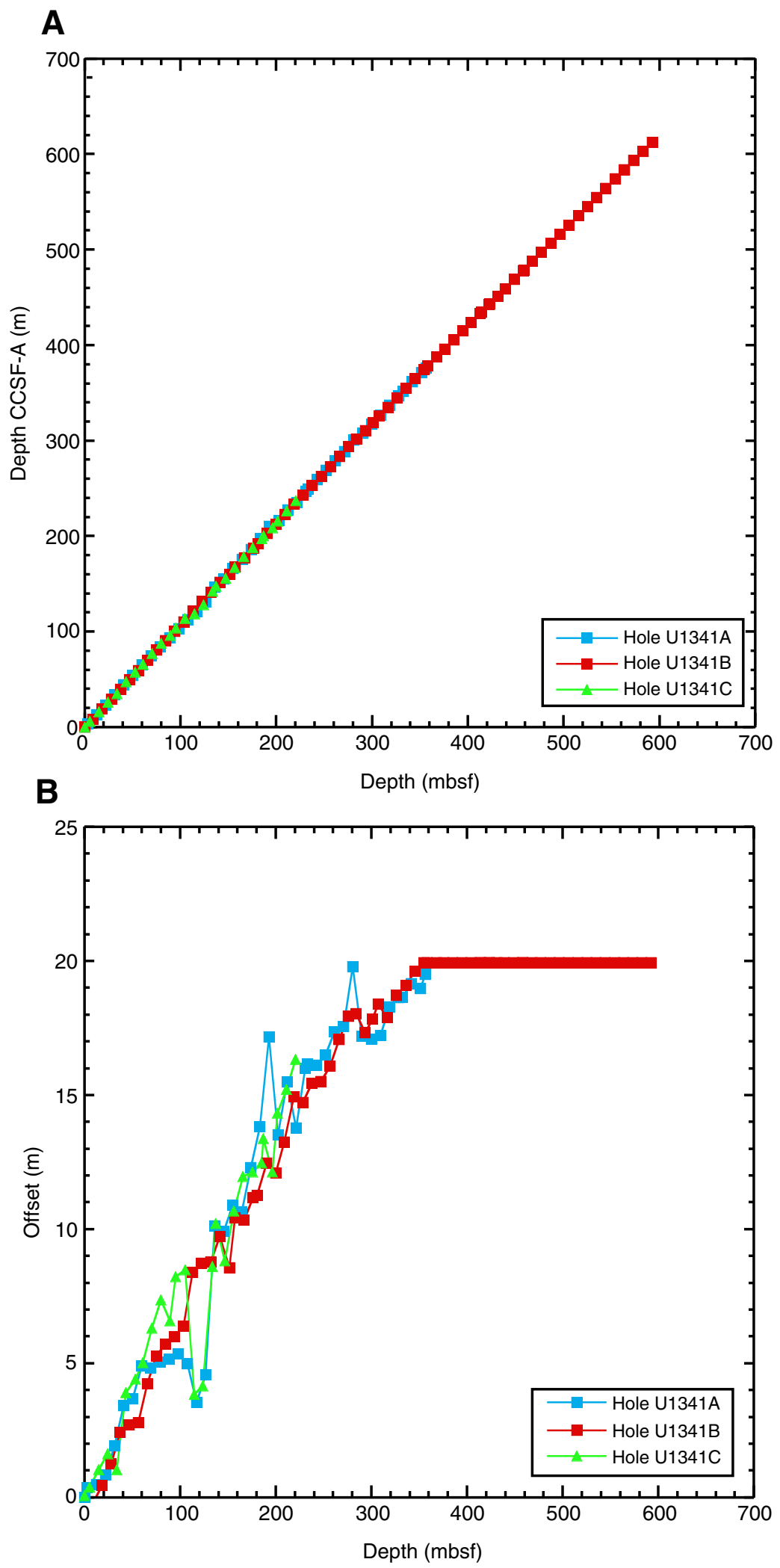
Figure F36. Summary of logs recorded by the triple combination tool string, Hole U1341B. HLDS = Hostile Environment Litho-Density Sonde. gAPI = American Petroleum Institute gamma ray units, $\mathrm{c} / \mathrm{s}=$ counts per second. $\mathrm{MAD}=$ moisture and density, GRA = gamma ray attenuation bulk density, IDPH = deep induction phasor-processed resistivity, IMPH = medium induction phasor-processed resistivity, SFLU = spherically focused resistivity.

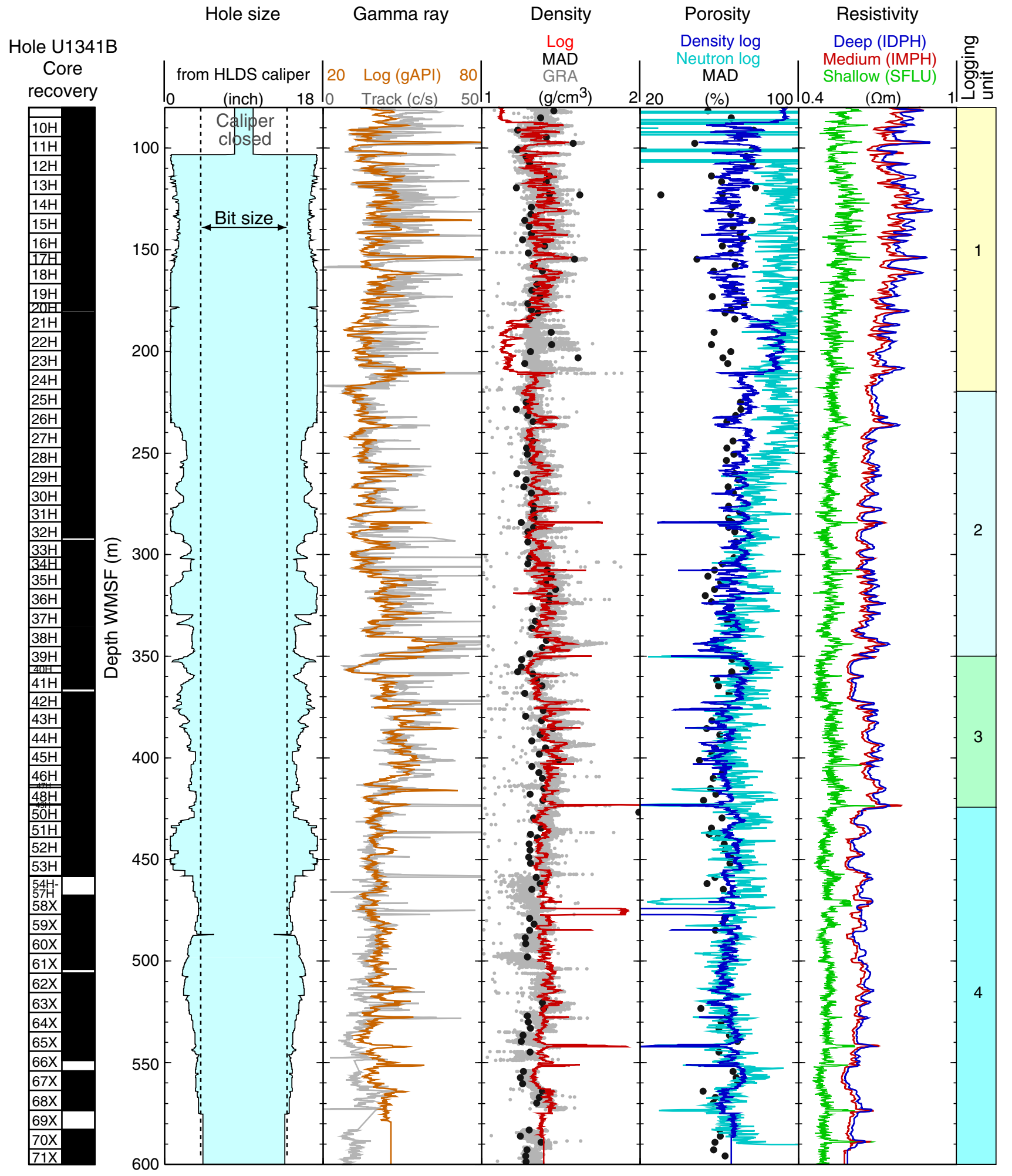


Figure F37. Summary of logs recorded by the Formation MicroScanner (FMS)-sonic tool string, Hole U1341B. Hole size is calculated by the two orthogonal calipers of the FMS (C1 and C2). Hole size measured by the Hostile Environment Litho-Density Sonde (HLDS) caliper during the triple combination (TC) run is shown in gray for comparison. The gamma ray log recorded during the main pass of the triple combination tool string is also shown for comparison and to confirm the good match between the two runs. High waveform coherence (red in the velocity tracks) is a measure of the reliability of the slowness/time coherence algorithm used to derive compressional $\left(V_{\mathrm{P}}\right)$ and shear $\left(V_{\mathrm{S}}\right)$ velocities from the recorded waveforms, including the upper and lower dipoles $(\mathrm{UD}$ and LD). gAPI $=$ American Petroleum Institute gamma ray units.

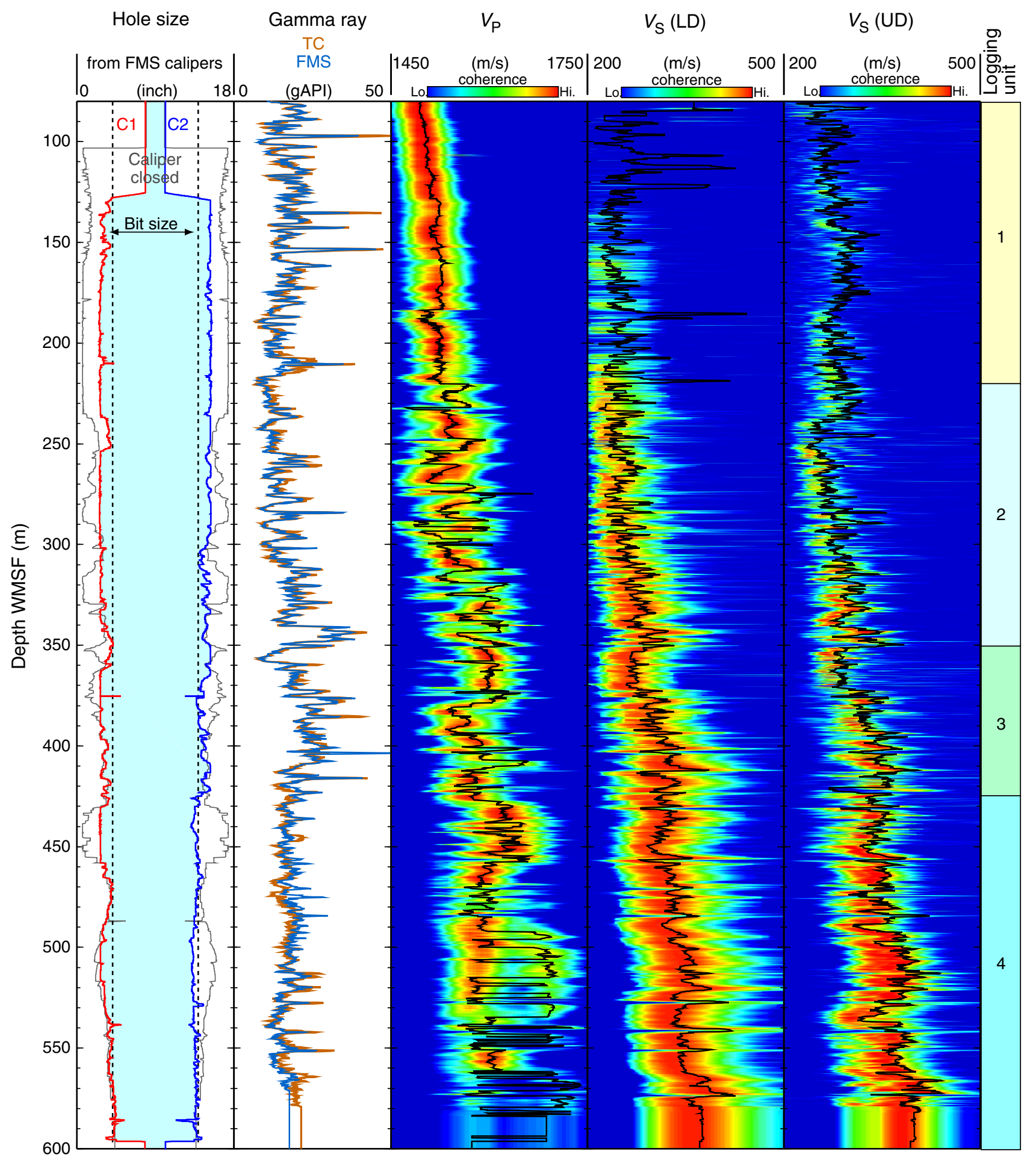


Figure F38. Summary of spectral natural gamma ray measurements, Hole U1341B. CGR = computed gamma ray (gamma ray without the uranium contribution), GR = total gamma ray. The area between the two curves shows the contribution of uranium, an indicator of organic content. gAPI $=$ American Petroleum Institute gamma ray units.

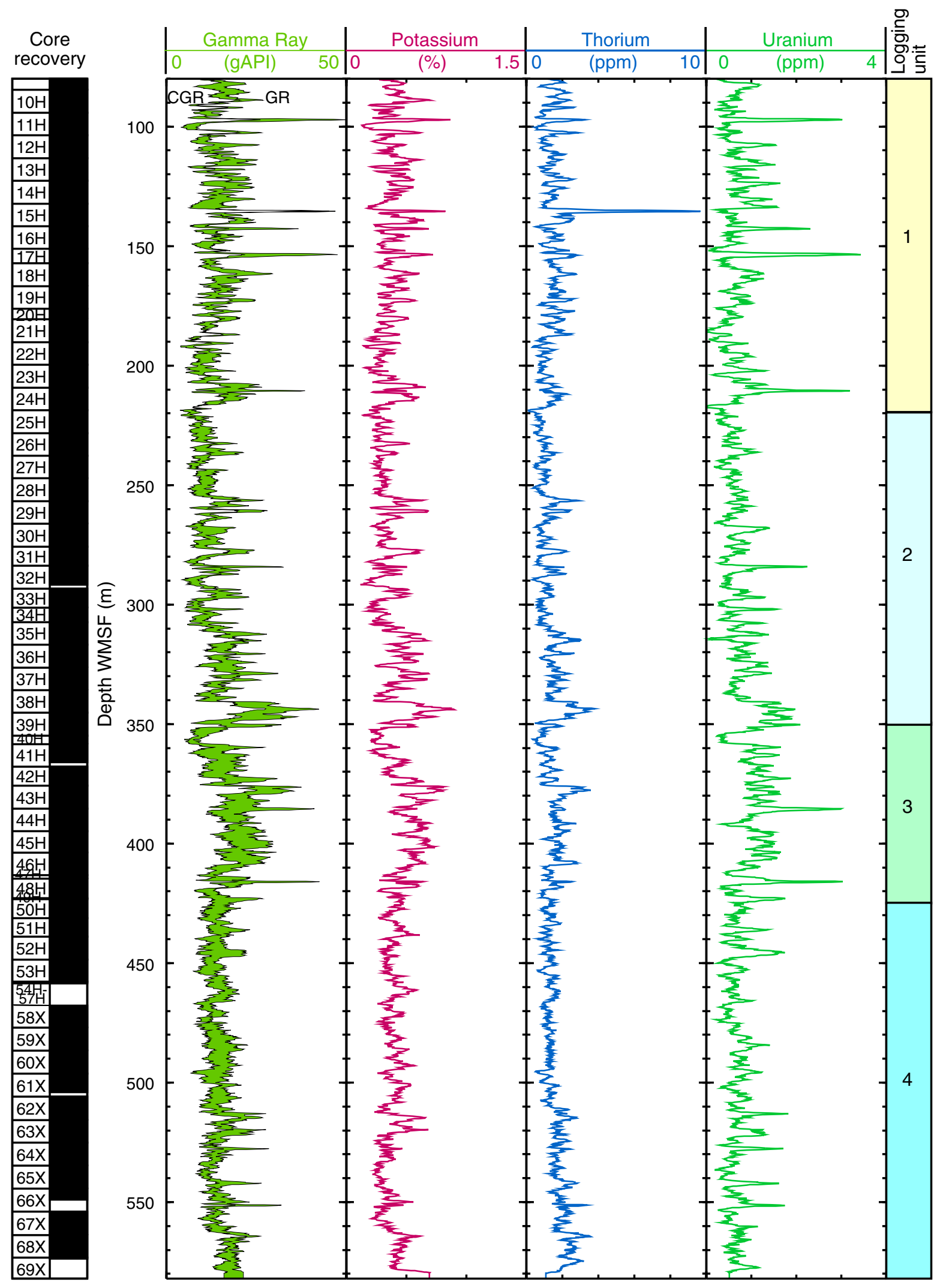


Figure F39. Correlation between Formation MicroScanner (FMS) electrical images and core observations. (A, B) Authigenic carbonates and (C) dolostone generate higher resistivity, which is apparent as brighter color in the FMS images. The depths of the FMS images have been adjusted by up to $50 \mathrm{~cm}$ to illustrate the correlations. The contrast in the core images has been increased to enhance the carbonates.
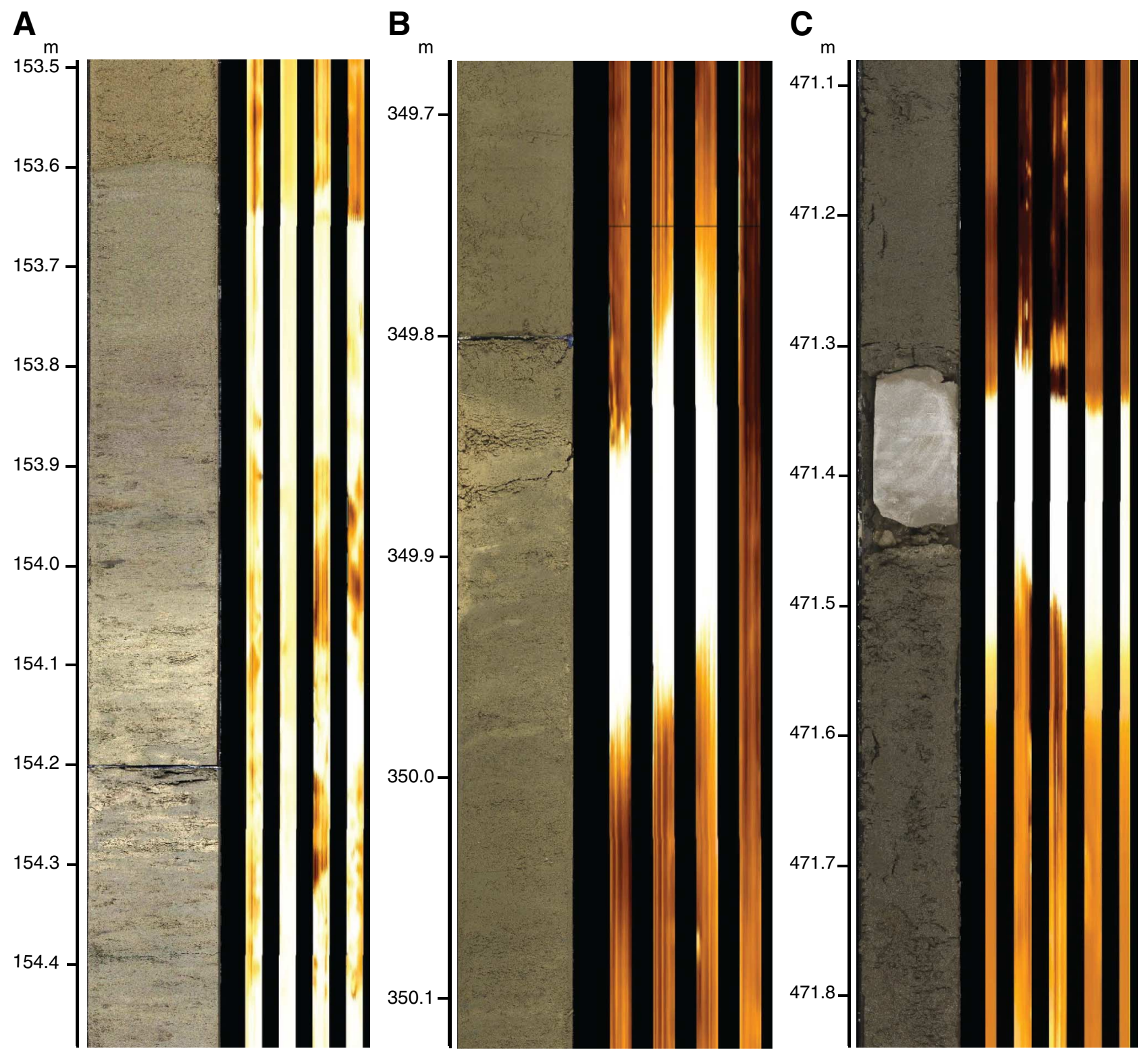
Figure F40. Comparison of synthetic seismogram calculated from density and $V_{\mathrm{p}}$ logs in Hole U1341B and multichannel seismic (MCS) Line Stk5-1 (Sakamoto et al., 2005) near Site U1341. The gamma ray log is shown as a reference to the other logs and the logging units. A constant density value was used between 180 and 210 mbsf to correct for poor data quality. gAPI = American Petroleum Institute gamma ray units.

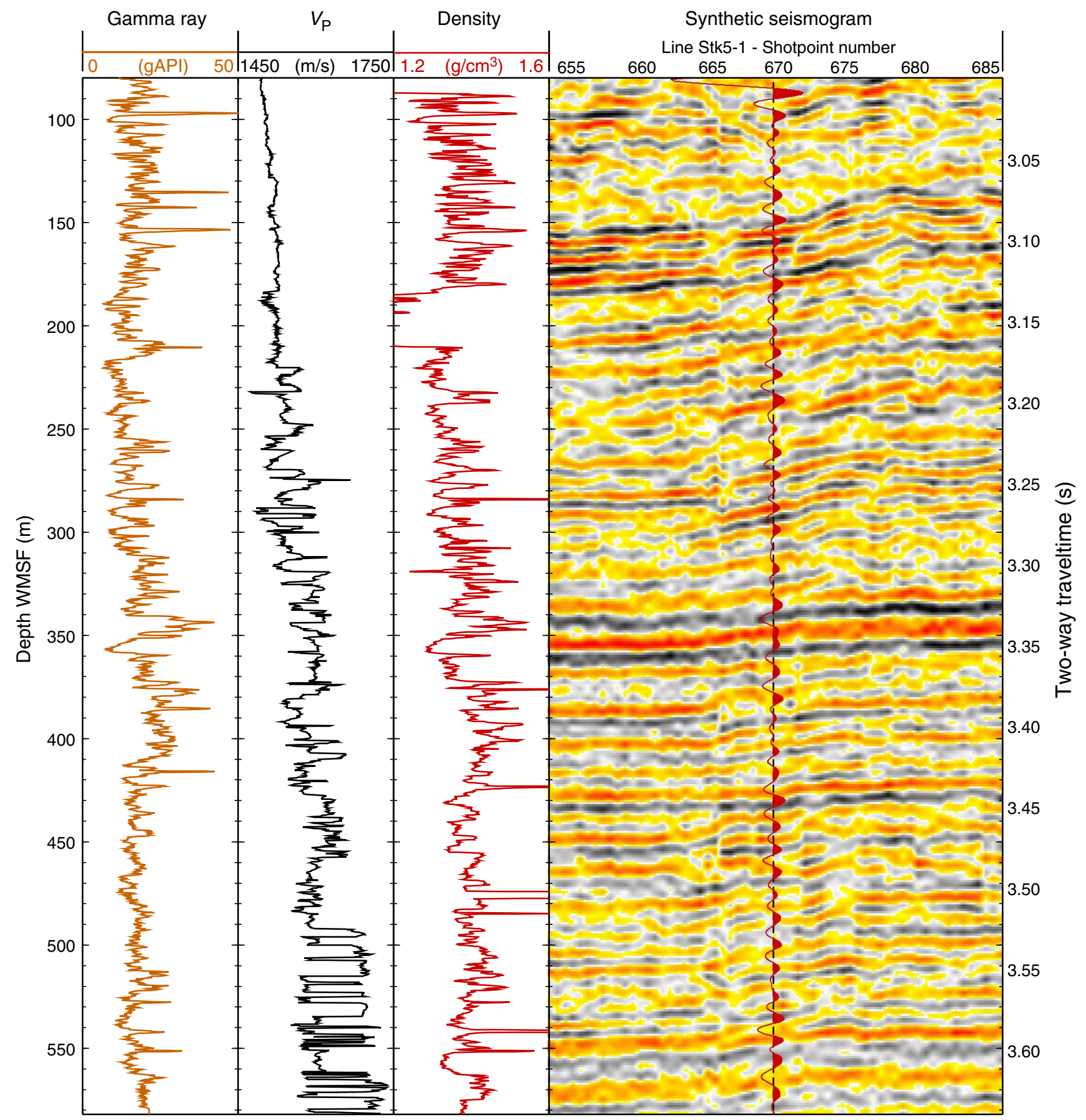


Figure F41. A. Records of APCT-3 penetrations and temperature decays, Hole U1341A. B. Summary of temperature measurements.

A
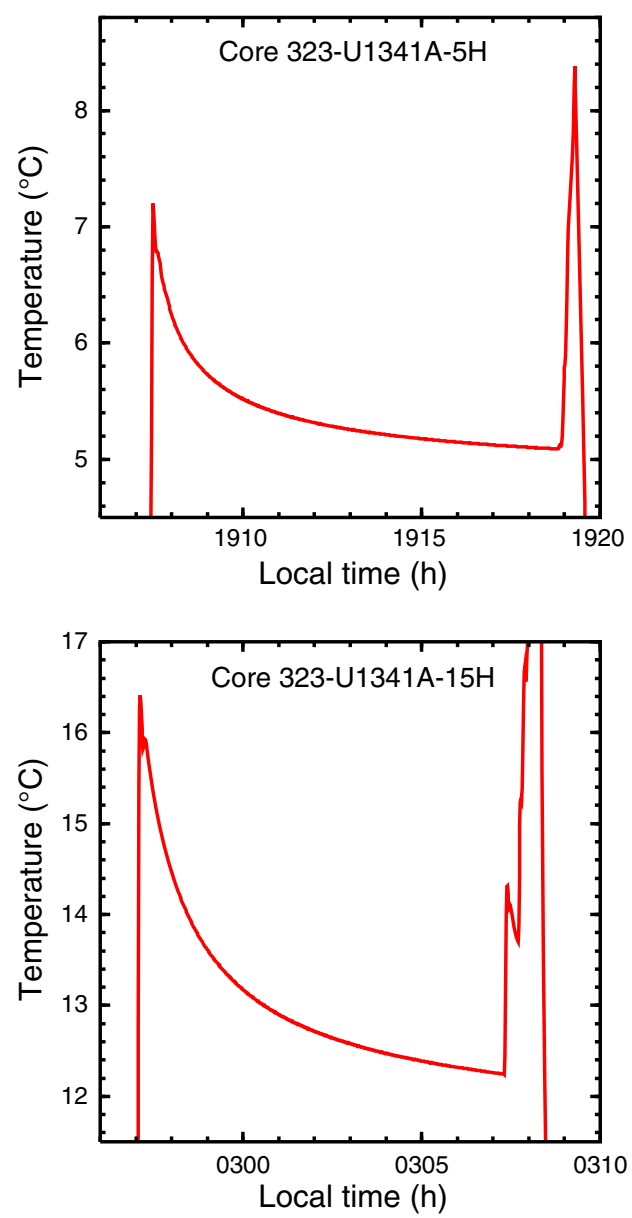

B
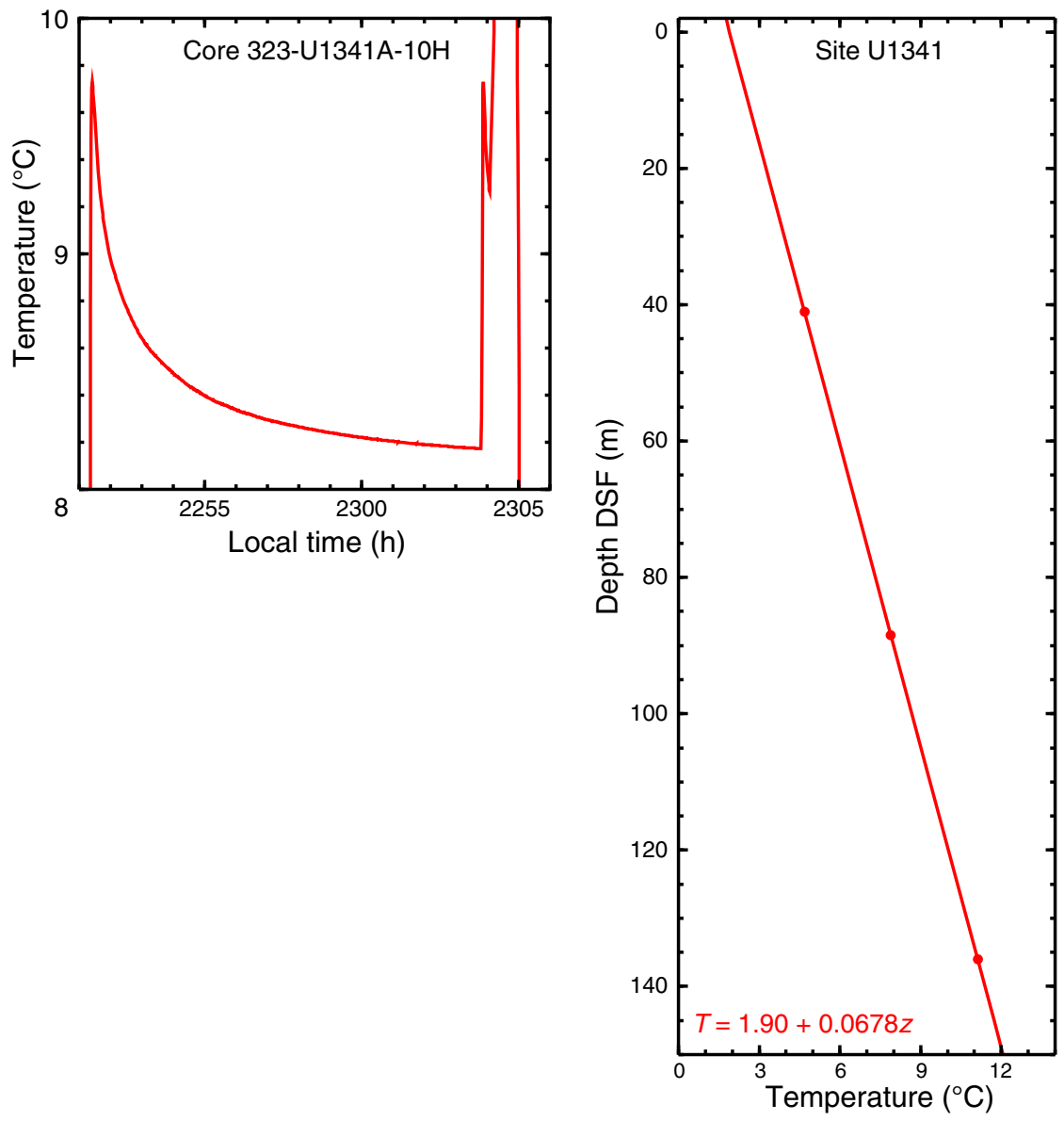
Table T1. Coring summary, Holes U1341A, U1341B, and U1341C. (See table notes.) (Continued on next two pages.)

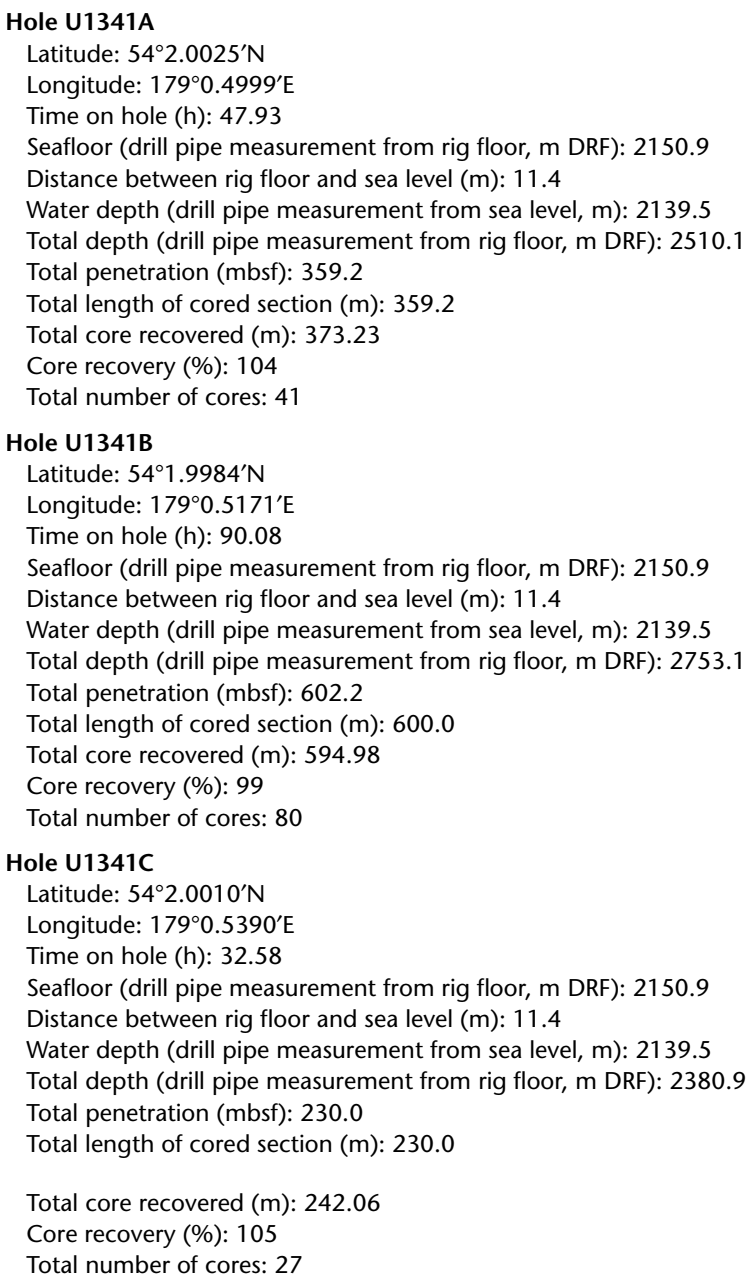

\begin{tabular}{|c|c|c|c|c|c|c|c|c|}
\hline \multirow[b]{2}{*}{ Core } & \multirow{2}{*}{$\begin{array}{l}\text { Date } \\
\text { (2009) }\end{array}$} & \multirow{2}{*}{$\begin{array}{l}\text { UTC } \\
\text { (h) }\end{array}$} & \multicolumn{2}{|c|}{ Depth DSF (m) } & \multicolumn{2}{|c|}{ Length $(\mathrm{m})$} & \multirow{2}{*}{$\begin{array}{c}\text { Recovery } \\
\text { (\%) }\end{array}$} & \multirow[b]{2}{*}{ Comments } \\
\hline & & & Top & Bottom & Cored & Recovered & & \\
\hline \multicolumn{9}{|c|}{ 323-U1341A- } \\
\hline $1 \mathrm{H}$ & $27 \mathrm{Jul}$ & 1630 & 0.0 & 3.0 & 3.0 & 3.04 & 101 & Oriented nonmagnetic barrel \\
\hline $2 \mathrm{H}$ & $27 \mathrm{Jul}$ & 1710 & 3.0 & 12.5 & 9.5 & 9.64 & 101 & Oriented nonmagnetic barrel \\
\hline $3 \mathrm{H}$ & $27 \mathrm{Jul}$ & 1755 & 12.5 & 22.0 & 9.5 & 9.93 & 105 & Oriented nonmagnetic barrel \\
\hline $4 \mathrm{H}$ & $27 \mathrm{Jul}$ & 1840 & 22.0 & 31.5 & 9.5 & 9.77 & 103 & Oriented nonmagnetic barrel \\
\hline $5 \mathrm{H}$ & $27 \mathrm{Jul}$ & 1935 & 31.5 & 41.0 & 9.5 & 9.82 & 103 & Oriented nonmagnetic barrel \\
\hline $6 \mathrm{H}$ & $27 \mathrm{Jul}$ & 2010 & 41.0 & 50.5 & 9.5 & 9.95 & 105 & Oriented nonmagnetic barrel \\
\hline $7 \mathrm{H}$ & $27 \mathrm{Jul}$ & 2055 & 50.5 & 60.0 & 9.5 & 10.01 & 105 & Oriented nonmagnetic barrel \\
\hline $8 \mathrm{H}$ & $27 \mathrm{Jul}$ & 2135 & 60.0 & 69.5 & 9.5 & 9.41 & 99 & Oriented nonmagnetic barrel \\
\hline $9 \mathrm{H}$ & $27 \mathrm{Jul}$ & 2215 & 69.5 & 79.0 & 9.5 & 10.16 & 107 & Oriented nonmagnetic barrel \\
\hline $10 \mathrm{H}$ & $27 \mathrm{Jul}$ & 2320 & 79.0 & 88.5 & 9.5 & 10.12 & 107 & Oriented nonmagnetic barrel \\
\hline $11 \mathrm{H}$ & $28 \mathrm{Jul}$ & 0015 & 88.5 & 98.0 & 9.5 & 10.01 & 105 & Oriented nonmagnetic barrel \\
\hline $12 \mathrm{H}$ & $28 \mathrm{Jul}$ & 0055 & 98.0 & 107.5 & 9.5 & 10.16 & 107 & Oriented nonmagnetic barrel \\
\hline $13 \mathrm{H}$ & $28 \mathrm{Jul}$ & 0140 & 107.5 & 117.0 & 9.5 & 10.20 & 107 & Oriented nonmagnetic barrel \\
\hline $14 \mathrm{H}$ & $28 \mathrm{Jul}$ & 0225 & 117.0 & 126.5 & 9.5 & 10.10 & 106 & Oriented nonmagnetic barrel \\
\hline $15 \mathrm{H}$ & $28 \mathrm{Jul}$ & 0320 & 126.5 & 136.0 & 9.5 & 9.76 & 103 & Oriented nonmagnetic barrel, split liner \\
\hline $16 \mathrm{H}$ & $28 \mathrm{Jul}$ & 0415 & 136.0 & 145.5 & 9.5 & 10.07 & 106 & Oriented nonmagnetic barrel \\
\hline $17 \mathrm{H}$ & $28 \mathrm{Jul}$ & 0500 & 145.5 & 155.0 & 9.5 & 10.13 & 107 & Oriented nonmagnetic barrel \\
\hline $18 \mathrm{H}$ & $28 \mathrm{Jul}$ & 0550 & 155.0 & 164.5 & 9.5 & 10.02 & 105 & Oriented nonmagnetic barrel \\
\hline $19 \mathrm{H}$ & $28 \mathrm{Jul}$ & 0635 & 164.5 & 174.0 & 9.5 & 9.99 & 105 & Oriented nonmagnetic barrel \\
\hline $20 \mathrm{H}$ & $28 \mathrm{Jul}$ & 0720 & 174.0 & 183.5 & 9.5 & 9.92 & 104 & Oriented nonmagnetic barrel \\
\hline $21 \mathrm{H}$ & $28 \mathrm{Jul}$ & 0835 & 183.5 & 193.0 & 9.5 & 9.85 & 104 & Steel barrel \\
\hline $22 \mathrm{H}$ & $28 \mathrm{Jul}$ & 0930 & 193.0 & 202.5 & 9.5 & 10.13 & 107 & Steel barrel \\
\hline $23 \mathrm{H}$ & $28 \mathrm{Jul}$ & 1045 & 202.5 & 212.0 & 9.5 & 10.13 & 107 & Steel barrel \\
\hline $24 \mathrm{H}$ & $28 \mathrm{Jul}$ & 1145 & 212.0 & 221.5 & 9.5 & 9.34 & 98 & Steel barrel \\
\hline
\end{tabular}


Table T1 (continued). (Continued on next page.)

\begin{tabular}{|c|c|c|c|c|c|c|c|c|}
\hline \multirow[b]{2}{*}{ Core } & \multirow{2}{*}{$\begin{array}{l}\text { Date } \\
\text { (2009) }\end{array}$} & \multirow{2}{*}{$\begin{array}{l}\text { UTC } \\
\text { (h) }\end{array}$} & \multicolumn{2}{|c|}{ Depth DSF $(m)$} & \multicolumn{2}{|c|}{ Length $(\mathrm{m})$} & \multirow{2}{*}{$\begin{array}{c}\text { Recovery } \\
\text { (\%) }\end{array}$} & \multirow[b]{2}{*}{ Comments } \\
\hline & & & Top & Bottom & Cored & Recovered & & \\
\hline $25 \mathrm{H}$ & $28 \mathrm{Jul}$ & 1235 & 221.5 & 231.0 & 9.5 & 9.93 & 105 & Steel barrel \\
\hline $26 \mathrm{H}$ & $28 \mathrm{Jul}$ & 1320 & 231.0 & 233.2 & 2.2 & 2.21 & 100 & Steel barrel \\
\hline $27 \mathrm{H}$ & $28 \mathrm{Jul}$ & 1430 & 233.2 & 242.7 & 9.5 & 8.30 & 87 & Steel barrel \\
\hline $28 \mathrm{H}$ & $28 \mathrm{Jul}$ & 1520 & 242.7 & 252.2 & 9.5 & 9.84 & 104 & Steel barrel \\
\hline $29 \mathrm{H}$ & $28 \mathrm{Jul}$ & 1615 & 252.2 & 261.7 & 9.5 & 10.04 & 106 & Steel barrel \\
\hline $30 \mathrm{H}$ & $28 \mathrm{Jul}$ & 1700 & 261.7 & 271.2 & 9.5 & 10.12 & 107 & Steel barrel \\
\hline $31 \mathrm{H}$ & $28 \mathrm{Jul}$ & 1755 & 271.2 & 280.7 & 9.5 & 10.10 & 106 & Steel barrel \\
\hline $32 \mathrm{H}$ & $28 \mathrm{Jul}$ & 1845 & 280.7 & 290.2 & 9.5 & 9.91 & 104 & Steel barrel \\
\hline $33 \mathrm{H}$ & $28 \mathrm{Jul}$ & 1935 & 290.2 & 299.7 & 9.5 & 9.99 & 105 & Steel barrel \\
\hline $34 \mathrm{H}$ & $28 \mathrm{Jul}$ & 2110 & 299.7 & 309.2 & 9.5 & 9.82 & 103 & Steel barrel \\
\hline $35 \mathrm{H}$ & $28 \mathrm{Jul}$ & 2200 & 309.2 & 318.7 & 9.5 & 9.82 & 103 & Steel barrel \\
\hline $36 \mathrm{H}$ & $28 \mathrm{Jul}$ & 2300 & 318.7 & 328.2 & 9.5 & 9.49 & 100 & Steel barrel \\
\hline $37 \mathrm{H}$ & $28 \mathrm{Jul}$ & 2355 & 328.2 & 332.7 & 4.5 & 4.61 & 102 & Steel barrel \\
\hline $38 \mathrm{H}$ & 29 Jul & 0110 & 332.7 & 342.2 & 9.5 & 9.56 & 101 & Steel barrel \\
\hline $39 \mathrm{H}$ & 29 Jul & 0220 & 342.2 & 351.7 & 9.5 & 9.83 & 103 & Steel barrel \\
\hline $40 \mathrm{H}$ & $29 \mathrm{Jul}$ & 0320 & 351.7 & 356.2 & 4.5 & 5.08 & 113 & Steel barrel \\
\hline \multirow{2}{*}{$41 \mathrm{H}$} & $29 \mathrm{Jul}$ & 0430 & 356.2 & 359.2 & 3.0 & 2.92 & 97 & Steel barrel \\
\hline & & & \multicolumn{2}{|c|}{ Cored totals: } & 359.2 & 373.23 & 104 & \\
\hline \multicolumn{9}{|c|}{ 323-U1341B- } \\
\hline $1 \mathrm{H}$ & 29 Jul & 1000 & 0.0 & 8.7 & 8.7 & 8.72 & 100 & Oriented nonmagnetic barrel \\
\hline $2 \mathrm{H}$ & $29 \mathrm{Jul}$ & 1050 & 8.7 & 18.2 & 9.5 & 9.88 & 104 & Oriented nonmagnetic barrel \\
\hline $3 \mathrm{H}$ & 29 Jul & 1135 & 18.2 & 27.7 & 9.5 & 9.98 & 105 & Oriented nonmagnetic barrel \\
\hline $4 \mathrm{H}$ & 29 Jul & 1215 & 27.7 & 37.2 & 9.5 & 10.00 & 105 & Oriented nonmagnetic barrel \\
\hline $5 \mathrm{H}$ & 29 Jul & 1255 & 37.2 & 46.7 & 9.5 & 9.98 & 105 & Oriented nonmagnetic barrel \\
\hline $6 \mathrm{H}$ & 29 Jul & 1335 & 46.7 & 56.2 & 9.5 & 10.42 & 110 & Oriented nonmagnetic barrel \\
\hline $7 \mathrm{H}$ & $29 \mathrm{Jul}$ & 1420 & 56.2 & 65.7 & 9.5 & 9.98 & 105 & Oriented nonmagnetic barrel \\
\hline $8 \mathrm{H}$ & $29 \mathrm{Jul}$ & 1455 & 65.7 & 75.2 & 9.5 & 10.05 & 106 & Oriented nonmagnetic barrel \\
\hline $9 \mathrm{H}$ & $29 \mathrm{Jul}$ & 1535 & 75.2 & 84.7 & 9.5 & 10.04 & 106 & Oriented nonmagnetic barrel \\
\hline $10 \mathrm{H}$ & $29 \mathrm{Jul}$ & 1620 & 84.7 & 94.2 & 9.5 & 9.50 & 100 & Oriented nonmagnetic barrel \\
\hline $11 \mathrm{H}$ & 29 Jul & 1700 & 94.2 & 103.7 & 9.5 & 10.05 & 106 & Oriented nonmagnetic barrel \\
\hline $12 \mathrm{H}$ & $29 \mathrm{Jul}$ & 1735 & 103.7 & 113.2 & 9.5 & 9.89 & 104 & Oriented nonmagnetic barrel \\
\hline $13 \mathrm{H}$ & 29 Jul & 1820 & 113.2 & 122.7 & 9.5 & 10.04 & 106 & Oriented nonmagnetic barrel \\
\hline $14 \mathrm{H}$ & $29 \mathrm{Jul}$ & 1900 & 122.7 & 132.2 & 9.5 & 10.14 & 107 & Oriented nonmagnetic barrel \\
\hline $15 \mathrm{H}$ & 29 Jul & 1940 & 132.2 & 141.7 & 9.5 & 10.16 & 107 & Oriented nonmagnetic barrel \\
\hline $16 \mathrm{H}$ & 29 Jul & 2030 & 141.7 & 151.2 & 9.5 & 9.98 & 105 & Oriented nonmagnetic barrel \\
\hline $17 \mathrm{H}$ & $29 \mathrm{Jul}$ & 2115 & 151.2 & 157.2 & 6.0 & 6.99 & 116 & Oriented nonmagnetic barrel \\
\hline $18 \mathrm{H}$ & 29 Jul & 2215 & 157.2 & 166.7 & 9.5 & 9.61 & 101 & Oriented nonmagnetic barrel \\
\hline $19 \mathrm{H}$ & $29 \mathrm{Jul}$ & 2330 & 166.7 & 176.2 & 9.5 & 9.95 & 105 & Steel barrel \\
\hline $20 \mathrm{H}$ & $30 \mathrm{Jul}$ & 0035 & 176.2 & 180.7 & 4.5 & 3.97 & 88 & Steel barrel \\
\hline $21 \mathrm{H}$ & $30 \mathrm{Jul}$ & 0125 & 180.7 & 190.2 & 9.5 & 10.02 & 105 & Steel barrel \\
\hline $22 \mathrm{H}$ & $30 \mathrm{Jul}$ & 0220 & 190.2 & 199.7 & 9.5 & 9.77 & 103 & Steel barrel \\
\hline $23 \mathrm{H}$ & $30 \mathrm{Jul}$ & 0315 & 199.7 & 209.2 & 9.5 & 10.08 & 106 & Steel barrel \\
\hline $24 \mathrm{H}$ & $30 \mathrm{Jul}$ & 0420 & 209.2 & 218.7 & 9.5 & 9.73 & 102 & Steel barrel \\
\hline $25 \mathrm{H}$ & $30 \mathrm{Jul}$ & 0510 & 218.7 & 228.2 & 9.5 & 9.82 & 103 & Steel barrel \\
\hline $26 \mathrm{H}$ & $30 \mathrm{Jul}$ & 0610 & 228.2 & 237.7 & 9.5 & 10.01 & 105 & Steel barrel \\
\hline $27 \mathrm{H}$ & $30 \mathrm{Jul}$ & 0700 & 237.7 & 247.2 & 9.5 & 9.90 & 104 & Steel barrel \\
\hline $28 \mathrm{H}$ & $30 \mathrm{Jul}$ & 0755 & 247.2 & 256.7 & 9.5 & 9.99 & 105 & Steel barrel \\
\hline $29 \mathrm{H}$ & $30 \mathrm{Jul}$ & 0850 & 256.7 & 266.2 & 9.5 & 9.32 & 98 & Steel barrel \\
\hline $30 \mathrm{H}$ & $30 \mathrm{Jul}$ & 0945 & 266.2 & 275.7 & 9.5 & 9.99 & 105 & Steel barrel \\
\hline $31 \mathrm{H}$ & $30 \mathrm{Jul}$ & 1030 & 275.7 & 283.8 & 8.1 & 8.11 & 100 & Steel barrel \\
\hline $32 \mathrm{H}$ & $30 \mathrm{Jul}$ & 1205 & 283.8 & 293.3 & 9.5 & 7.86 & 83 & Steel barrel, crushed, split liner \\
\hline $33 \mathrm{H}$ & $30 \mathrm{Jul}$ & 1255 & 293.3 & 301.2 & 7.9 & 7.93 & 100 & Steel barrel \\
\hline $34 \mathrm{H}$ & $30 \mathrm{Jul}$ & 1405 & 301.2 & 307.3 & 6.1 & 6.12 & 100 & Steel barrel \\
\hline $35 \mathrm{H}$ & $30 \mathrm{Jul}$ & 1515 & 307.3 & 316.8 & 9.5 & 9.45 & 99 & Steel barrel \\
\hline $36 \mathrm{H}$ & $30 \mathrm{Jul}$ & 1615 & 316.8 & 326.3 & 9.5 & 9.13 & 96 & Steel barrel \\
\hline $37 \mathrm{H}$ & $30 \mathrm{Jul}$ & 1745 & 326.3 & 335.8 & 9.5 & 8.98 & 95 & Steel barrel \\
\hline $38 \mathrm{H}$ & $30 \mathrm{Jul}$ & 1920 & 335.8 & 345.3 & 9.5 & 9.98 & 105 & Steel barrel \\
\hline $39 \mathrm{H}$ & $30 \mathrm{Jul}$ & 2015 & 345.3 & 354.8 & 9.5 & 9.79 & 103 & Steel barrel \\
\hline $40 \mathrm{H}$ & $30 \mathrm{Jul}$ & 2105 & 354.8 & 358.3 & 3.5 & 3.31 & 95 & Steel barrel \\
\hline $41 \mathrm{H}$ & $30 \mathrm{Jul}$ & 2210 & 358.3 & 367.8 & 9.5 & 7.94 & 84 & Steel barrel \\
\hline $42 \mathrm{H}$ & $30 \mathrm{Jul}$ & 2305 & 367.8 & 375.8 & 8.0 & 7.88 & 98 & Steel barrel \\
\hline $43 \mathrm{H}$ & 31 Jul & 0005 & 375.8 & 385.3 & 9.5 & 9.68 & 102 & Steel barrel, split liner \\
\hline $44 \mathrm{H}$ & 31 Jul & 0125 & 385.3 & 394.8 & 9.5 & 9.82 & 103 & Steel barrel, shattered liner \\
\hline $45 \mathrm{H}$ & $31 \mathrm{Jul}$ & 0225 & 394.8 & 403.8 & 9.0 & 8.79 & 98 & Steel barrel \\
\hline $46 \mathrm{H}$ & $31 \mathrm{Jul}$ & 0340 & 403.8 & 413.3 & 9.5 & 9.90 & 104 & Steel barrel \\
\hline $47 \mathrm{H}$ & $31 \mathrm{Jul}$ & 0430 & 413.3 & 414.6 & 1.3 & 1.23 & 95 & Steel barrel \\
\hline $48 \mathrm{H}$ & 31 Jul & 0545 & 414.6 & 422.8 & 8.2 & 8.24 & 100 & Steel barrel \\
\hline $49 \mathrm{H}$ & $31 \mathrm{Jul}$ & 0640 & 422.8 & 423.3 & 0.5 & 0.49 & 98 & Steel barrel \\
\hline
\end{tabular}


Table T1 (continued).

\begin{tabular}{|c|c|c|c|c|c|c|c|c|}
\hline \multirow[b]{2}{*}{ Core } & \multirow{2}{*}{$\begin{array}{l}\text { Date } \\
\text { (2009) }\end{array}$} & \multirow{2}{*}{$\begin{array}{l}\text { UTC } \\
\text { (h) }\end{array}$} & \multicolumn{2}{|c|}{ Depth DSF (m) } & \multicolumn{2}{|c|}{ Length $(\mathrm{m})$} & \multirow{2}{*}{$\begin{array}{c}\text { Recovery } \\
\text { (\%) }\end{array}$} & \multirow[b]{2}{*}{ Comments } \\
\hline & & & Top & Bottom & Cored & Recovered & & \\
\hline $50 \mathrm{H}$ & $31 \mathrm{Jul}$ & 0800 & 423.3 & 431.2 & 7.9 & 7.88 & 100 & Steel barrel \\
\hline $51 \mathrm{H}$ & $31 \mathrm{Jul}$ & 0855 & 431.2 & 439.0 & 7.8 & 7.84 & 101 & Steel barrel \\
\hline $52 \mathrm{H}$ & $31 \mathrm{Jul}$ & 1000 & 439.0 & 448.5 & 9.5 & 9.86 & 104 & Steel barrel \\
\hline $53 \mathrm{H}$ & 31 Jul & 1055 & 448.5 & 457.8 & 9.3 & 9.30 & 100 & Steel barrel \\
\hline $54 \mathrm{H}$ & $31 \mathrm{Jul}$ & 1140 & 457.8 & 458.3 & 0.5 & 0.53 & 106 & Steel barrel \\
\hline $55 \mathrm{H}$ & 31 Jul & 1225 & 458.3 & 458.4 & 0.1 & 0.06 & 60 & Steel barrel \\
\hline $56 \mathrm{H}$ & $31 \mathrm{Jul}$ & 1310 & 458.4 & 458.4 & 0.0 & 0.02 & 0 & Steel barrel \\
\hline $57 X$ & $31 \mathrm{Jul}$ & 1420 & 458.4 & 467.7 & 9.3 & 8.93 & 96 & Steel barrel \\
\hline $58 \mathrm{X}$ & $31 \mathrm{Jul}$ & 1520 & 467.7 & 477.0 & 9.3 & 9.05 & 97 & Steel barrel \\
\hline $59 \mathrm{X}$ & $31 \mathrm{Jul}$ & 1605 & 477.0 & 486.7 & 9.7 & 9.77 & 101 & Steel barrel \\
\hline $60 x$ & 31 Jul & 1645 & 486.7 & 496.2 & 9.5 & 9.76 & 103 & Steel barrel \\
\hline $61 x$ & 31 Jul & 1730 & 496.2 & 505.9 & 9.7 & 8.14 & 84 & Steel barrel \\
\hline $62 x$ & $31 \mathrm{Jul}$ & 1815 & 505.9 & 515.6 & 9.7 & 9.82 & 101 & Steel barrel \\
\hline $63 x$ & 31 Jul & 1855 & 515.6 & 525.2 & 9.6 & 9.86 & 103 & Steel barrel \\
\hline $64 X$ & 31 Jul & 1945 & 525.2 & 534.8 & 9.6 & 9.66 & 101 & Steel barrel \\
\hline $65 x$ & $31 \mathrm{Jul}$ & 2105 & 534.8 & 544.4 & 9.6 & 8.22 & 86 & Steel barrel \\
\hline $66 \mathrm{X}$ & $31 \mathrm{Jul}$ & 2150 & 544.4 & 554.0 & 9.6 & 4.96 & 52 & Steel barrel \\
\hline $67 X$ & 31 Jul & 2245 & 554.0 & 563.7 & 9.7 & 9.68 & 100 & Steel barrel \\
\hline $68 x$ & $31 \mathrm{Jul}$ & 2345 & 563.7 & 573.3 & 9.6 & 9.78 & 102 & Steel barrel \\
\hline $69 x$ & 1 Aug & 0035 & 573.3 & 582.9 & 9.6 & 0.24 & 2 & Steel barrel \\
\hline $70 \mathrm{x}$ & 1 Aug & 0130 & 582.9 & 592.5 & 9.6 & 9.66 & 101 & Steel barrel \\
\hline \multirow[t]{2}{*}{$71 x$} & 1 Aug & 0220 & 592.5 & 600.0 & 7.5 & 9.37 & 125 & Steel barrel \\
\hline & & & \multicolumn{2}{|c|}{ Cored totals: } & 600.0 & 594.98 & 99 & \\
\hline \multicolumn{9}{|c|}{ 323-U1341C- } \\
\hline $1 \mathrm{H}$ & 2 Aug & 0525 & 0.0 & 5.5 & 5.5 & 5.54 & 101 & Oriented nonmagnetic barrel \\
\hline $2 \mathrm{H}$ & 2 Aug & 0625 & 5.5 & 15.0 & 9.5 & 9.94 & 105 & Oriented nonmagnetic barrel \\
\hline $3 \mathrm{H}$ & 2 Aug & 0825 & 15.0 & 24.5 & 9.5 & 9.92 & 104 & Oriented nonmagnetic barrel \\
\hline $4 \mathrm{H}$ & 2 Aug & 0925 & 24.5 & 34.0 & 9.5 & 10.01 & 105 & Oriented nonmagnetic barrel \\
\hline $5 \mathrm{H}$ & 2 Aug & 1000 & 34.0 & 43.5 & 9.5 & 7.79 & 82 & Oriented nonmagnetic barrel \\
\hline $6 \mathrm{H}$ & 2 Aug & 1045 & 43.5 & 53.0 & 9.5 & 10.12 & 107 & Oriented nonmagnetic barrel \\
\hline $7 \mathrm{H}$ & 2 Aug & 1200 & 53.0 & 61.0 & 8.0 & 9.24 & 116 & Oriented nonmagnetic barrel \\
\hline $8 \mathrm{H}$ & 2 Aug & 1240 & 61.0 & 70.5 & 9.5 & 10.06 & 106 & Oriented nonmagnetic barrel \\
\hline $9 \mathrm{H}$ & 2 Aug & 1325 & 70.5 & 80.0 & 9.5 & 10.12 & 107 & Oriented nonmagnetic barrel \\
\hline $10 \mathrm{H}$ & 2 Aug & 1405 & 80.0 & 89.5 & 9.5 & 10.05 & 106 & Oriented nonmagnetic barrel \\
\hline $11 \mathrm{H}$ & 2 Aug & 1510 & 89.5 & 95.5 & 6.0 & 7.53 & 126 & Oriented nonmagnetic barrel \\
\hline $12 \mathrm{H}$ & 2 Aug & 1550 & 95.5 & 105.0 & 9.5 & 10.24 & 108 & Oriented nonmagnetic barrel \\
\hline $13 \mathrm{H}$ & 2 Aug & 1630 & 105.0 & 114.5 & 9.5 & 10.15 & 107 & Oriented nonmagnetic barrel \\
\hline $14 \mathrm{H}$ & 2 Aug & 1715 & 114.5 & 124.0 & 9.5 & 10.16 & 107 & Oriented nonmagnetic barrel \\
\hline $15 \mathrm{H}$ & 2 Aug & 1800 & 124.0 & 133.5 & 9.5 & 10.06 & 106 & Oriented nonmagnetic barrel \\
\hline $16 \mathrm{H}$ & 2 Aug & 1930 & 133.5 & 137.5 & 4.0 & 6.15 & 154 & Oriented nonmagnetic barrel \\
\hline $17 \mathrm{H}$ & 2 Aug & 2010 & 137.5 & 147.0 & 9.5 & 9.68 & 102 & Oriented nonmagnetic barrel \\
\hline $18 \mathrm{H}$ & 2 Aug & 2100 & 147.0 & 156.5 & 9.5 & 10.10 & 106 & Steel barrel \\
\hline $19 \mathrm{H}$ & 2 Aug & 2140 & 156.5 & 166.0 & 9.5 & 10.10 & 106 & Steel barrel \\
\hline $20 \mathrm{H}$ & 2 Aug & 2215 & 166.0 & 175.5 & 9.5 & 10.08 & 106 & Steel barrel \\
\hline $21 \mathrm{H}$ & 2 Aug & 2340 & 175.5 & 185.0 & 9.5 & 10.05 & 106 & Steel barrel \\
\hline $22 \mathrm{D}$ & & & & brilled fror & 185.0 to & $187.0 \mathrm{~m} \mathrm{DS}$ & 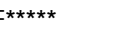 & \\
\hline $23 \mathrm{H}$ & 3 Aug & 0035 & 187.0 & 196.5 & 9.5 & 10.06 & 106 & Steel barrel \\
\hline $24 \mathrm{H}$ & 3 Aug & 0225 & 196.5 & 201.5 & 5.0 & 5.18 & 104 & Steel barrel \\
\hline $25 \mathrm{H}$ & 3 Aug & 0330 & 201.5 & 211.0 & 9.5 & 9.77 & 103 & Steel barrel \\
\hline $26 \mathrm{H}$ & 3 Aug & 0425 & 211.0 & 220.5 & 9.5 & 9.92 & 104 & Steel barrel \\
\hline \multirow[t]{3}{*}{$27 \mathrm{H}$} & 3 Aug & 0545 & 220.5 & 230.0 & 9.5 & 10.04 & 106 & Steel barrel \\
\hline & & & \multicolumn{2}{|c|}{ Cored totals: } & 230.0 & 242.06 & 106 & \\
\hline & & & \multicolumn{2}{|c|}{ Site totals: } & 1189.2 & 1210.27 & 102 & \\
\hline
\end{tabular}

Notes: DRF = drilling depth below rig floor, mbsf = meters below seafloor, DSF $=$ drilling depth below seafloor. UTC $=$ Universal Time Coordinated. 
Table T2. Datum events of radiolarians, calcareous nannofossils, diatoms, silicoflagellates, dinoflagellates, and ebridians, Holes U1341A, U1341B, and U1341C. (See table notes.)

\begin{tabular}{|c|c|c|c|c|c|}
\hline \multirow[b]{2}{*}{ Datum event } & \multirow[b]{2}{*}{ Taxon } & \multirow[b]{2}{*}{$\begin{array}{l}\text { Age } \\
\text { (Ma) }\end{array}$} & \multicolumn{3}{|c|}{ Depth (mbsf) } \\
\hline & & & $\begin{array}{c}\text { Hole } \\
\text { U1341A }\end{array}$ & $\begin{array}{c}\text { Hole } \\
\text { U1341B }\end{array}$ & $\begin{array}{c}\text { Hole } \\
\text { U1341C }\end{array}$ \\
\hline LO Lychnocanoma nipponica sakaii & Radiolarian & 0.05 & 7.83 & 4.36 & 10.49 \\
\hline LO Amphimelissa setosa & Radiolarian & $0.08-1$ & 7.83 & 13.65 & 20.18 \\
\hline LO Spongodiscus sp. & Radiolarian & $0.28-0.32$ & 36.55 & 42.44 & 57.93 \\
\hline LO Axoprunum acquilonium & Radiolarian & $0.25-0.43$ & 55.73 & 61.43 & - \\
\hline FO Emiliania huxleyi & Calcareous nannofossil & 0.29 & - & - & 34.41 \\
\hline LO Proboscia curvirostris & Diatom & 0.3 & 36.55 & 32.94 & 57.93 \\
\hline LO Thalassiosira jouseae & Diatom & 0.3 & 36.55 & 32.94 & - \\
\hline LO Proboscia barboi & Diatom & 0.3 & 36.55 & - & - \\
\hline LO Stylatractus universus & Radiolarian & $0.41-0.51$ & - & - & 57.93 \\
\hline LO Pseudoemiliania lacunosa & Calcareous nannofossil & 0.44 & - & - & 53.52 \\
\hline LO Dictyocha subarctios & Silicoflagellate & $0.6-0.7$ & 55.73 & - & - \\
\hline LCO Actinocyclus oculatus & Diatom & 0.9 & 131.68 & 118.42 & - \\
\hline LO Eucyrtidium matuyamai & Radiolarian & $0.9-1.5$ & 122.40 & 108.92 & 143.42 \\
\hline LO Filisphaera filifera & Dinoflagellate & $1.4-1.7$ & 202.99 & - & - \\
\hline FO Eucyrtidium matuyamai & Radiolarian & $1.7-1.9$ & 141.17 & 147.02 & 161.85 \\
\hline RI Neodenticula seminae & Diatom & 1.778 & - & 245.51 & - \\
\hline FO Proboscia curvirostris & Diatom & $1.7-2.0$ & - & 162.45 & - \\
\hline LO Stephanopyxis horridus & Diatom & $1.9-2.0$ & - & 204.88 & - \\
\hline LCO Neodenticula koizumii & Diatom & $2.1 \pm 0.1$ & 207.88 & 204.88 & - \\
\hline LO Ammodochium rectangulare & Ebridian & 1.9 & 237.36 & 233.37 & - \\
\hline LO Thecosphaera akitaensis & Radiolarian & $2.4-2.7$ & - & 414.12 & - \\
\hline LO Ebriopsis antiqua antiqua & Ebridian & $2.47-2.48$ & 330.50 & 330.61 & - \\
\hline LO Distephanus jimlingii & Silicoflagellate & 2.52 & 337.54 & 340.53 & - \\
\hline LCO Neodenticula kamtschatica & Diatom & 2.7 & - & 362.20 & - \\
\hline FO Neodenticula koizumii & Diatom & $3.7-3.9$ & - & 463.02 & - \\
\hline LO Dictyophimus bullatus/Dictyophimus sp. B & Radiolarian & $3.8-4.0$ & - & 597.06 & - \\
\hline
\end{tabular}

Notes: For first occurrences (FO), the depth was estimated as the midpoint between the depth at which the species was first observed and the depth of the next sample below. For last occurrences (LO), the depth was estimated as the midpoint between the depth at which the species was last observed and the depth of the next sample above. $\mathrm{LCO}=$ last common occurrence, $\mathrm{RI}=$ rapid increase, $-=$ not applicable. 


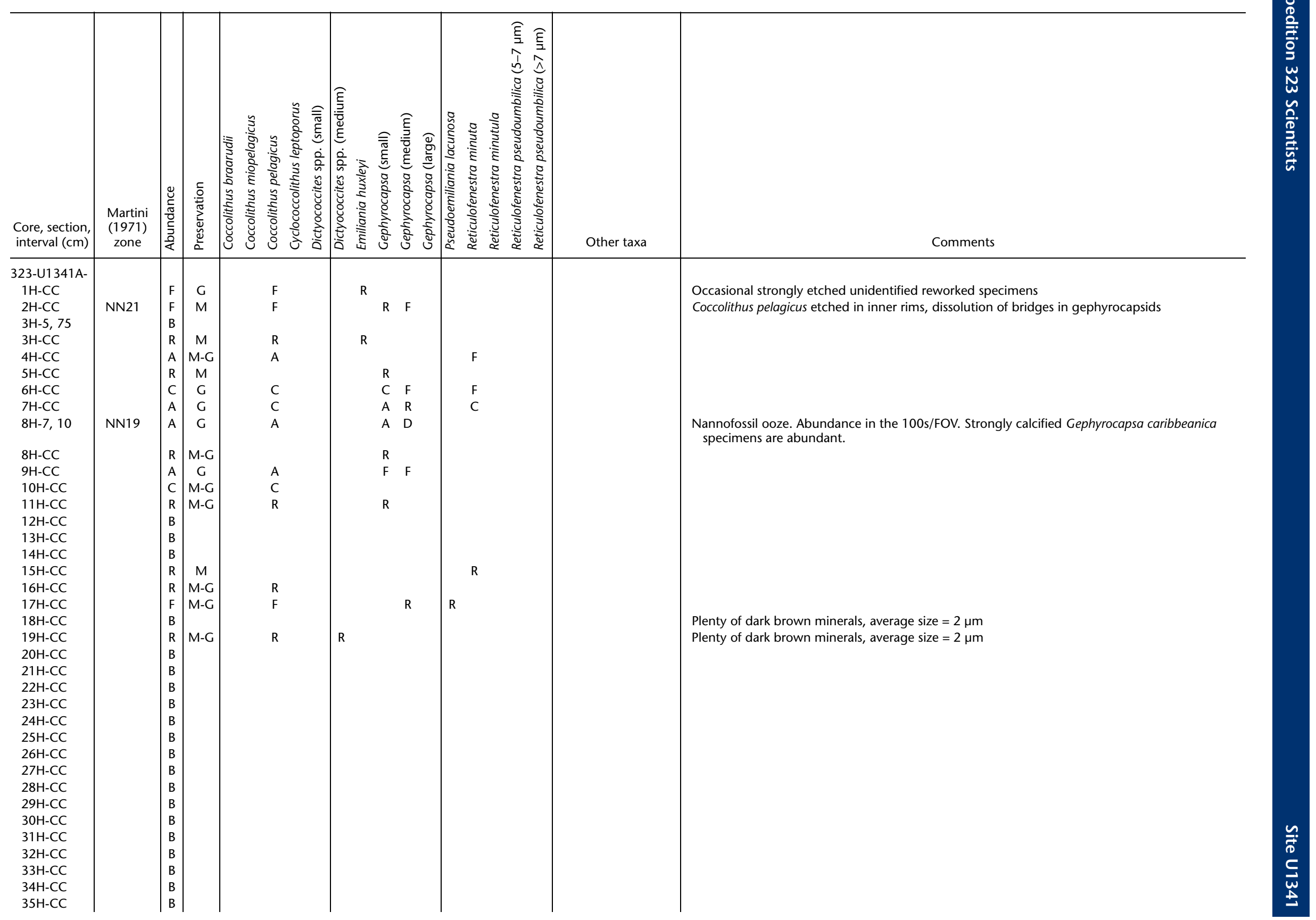


Table T3 (continued). (Continued on next page.)

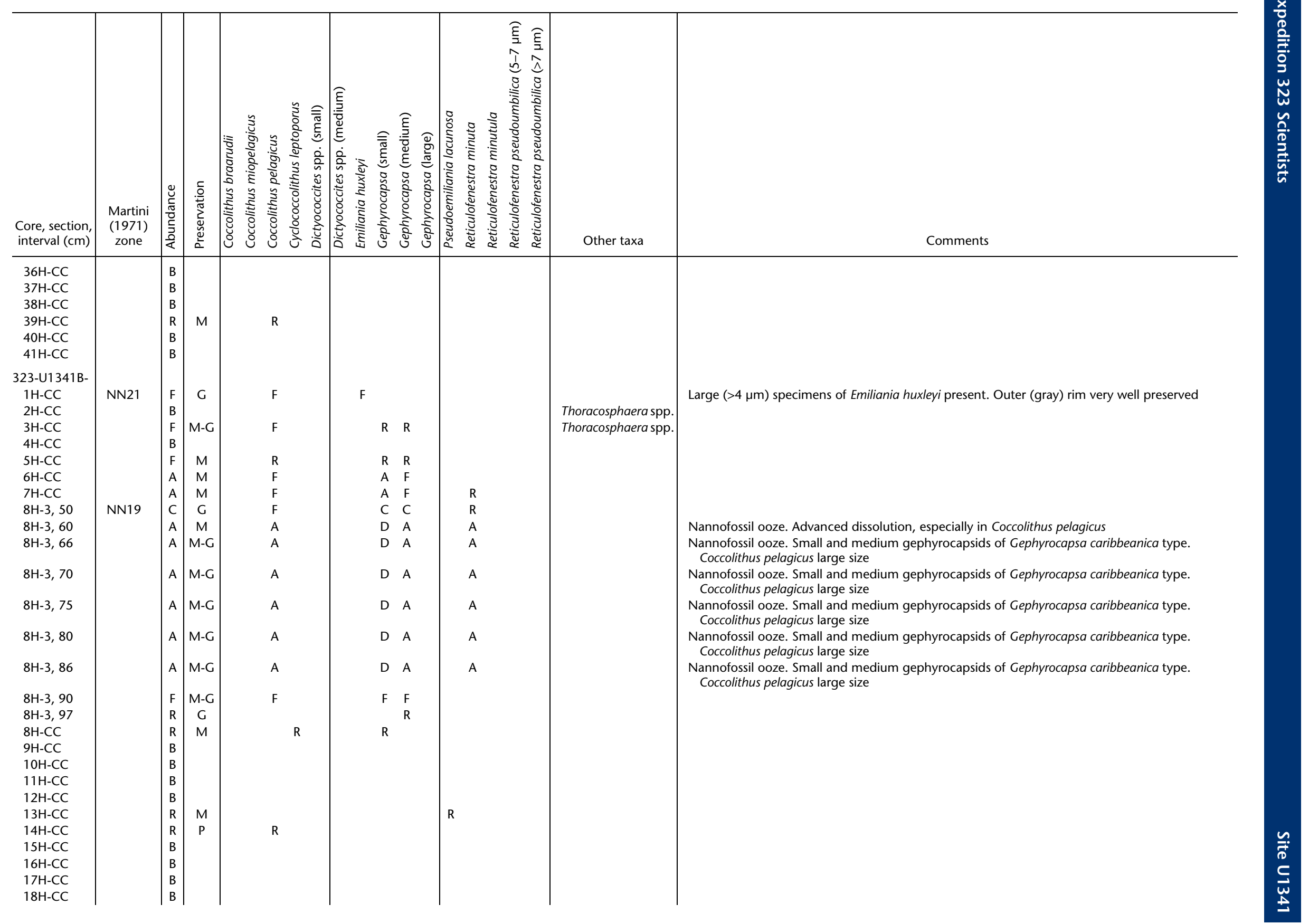


Table T3 (continued). (Continued on next page.)

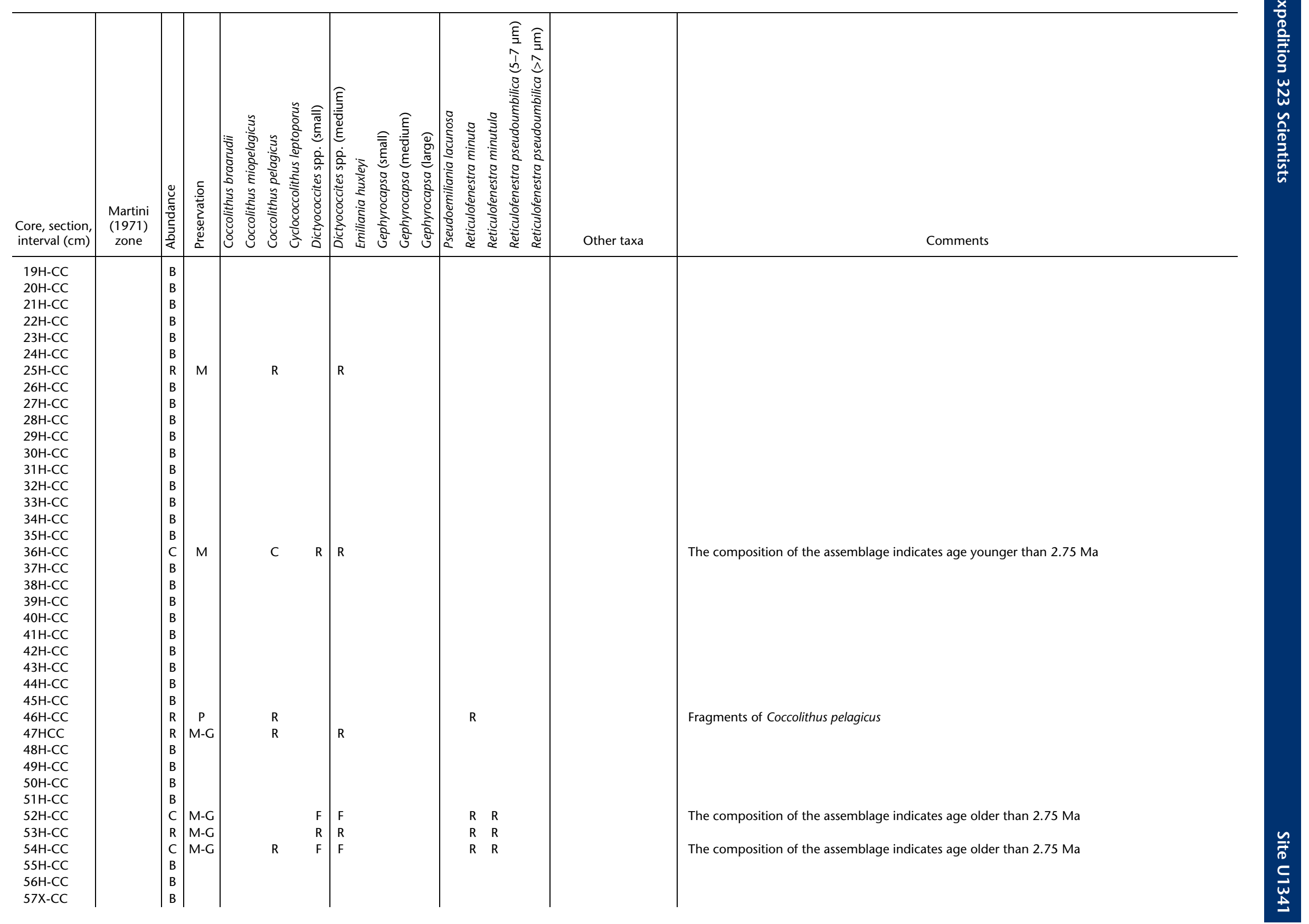


Table T3 (continued). (Continued on next page.)

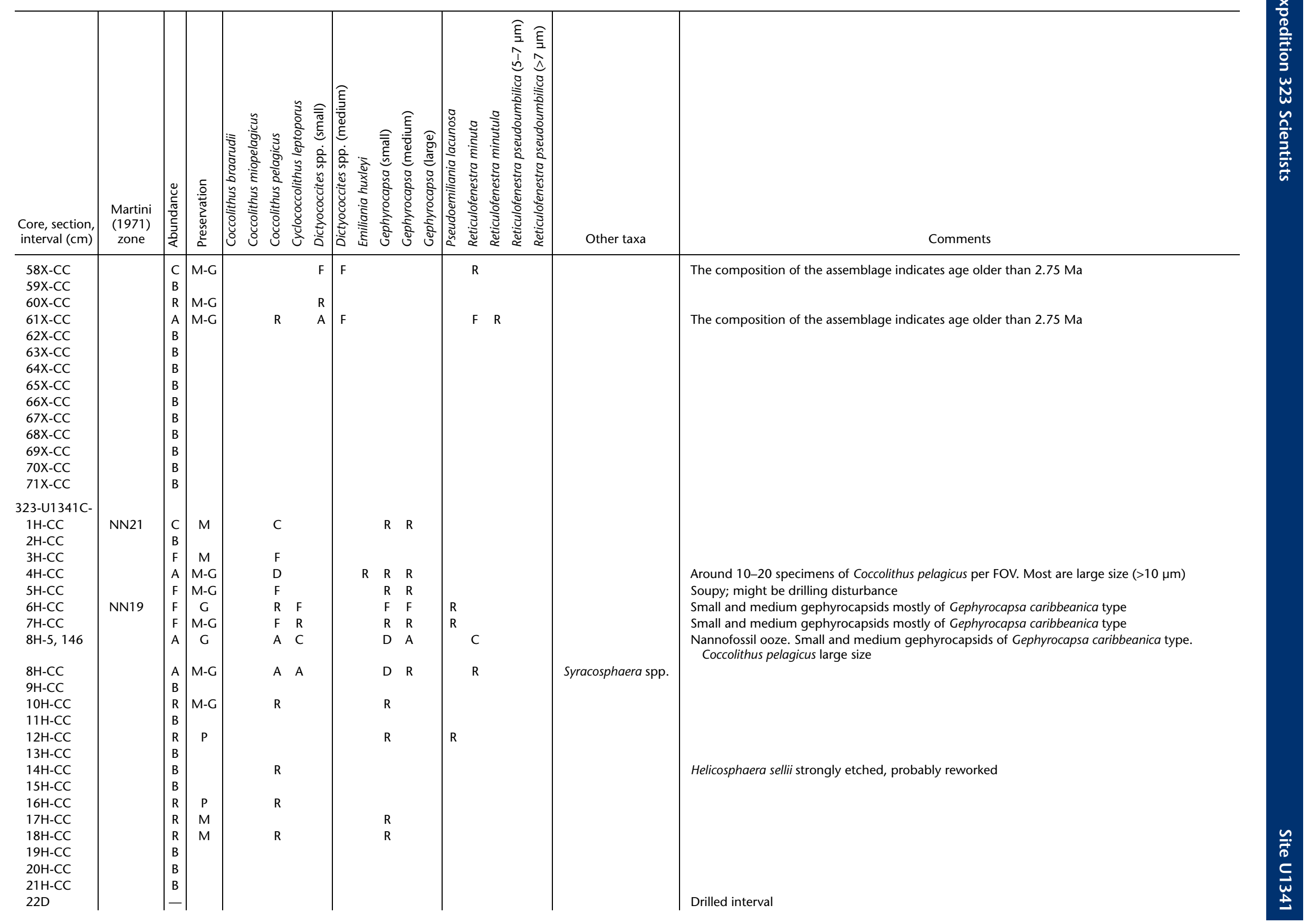


Table T3 (continued).

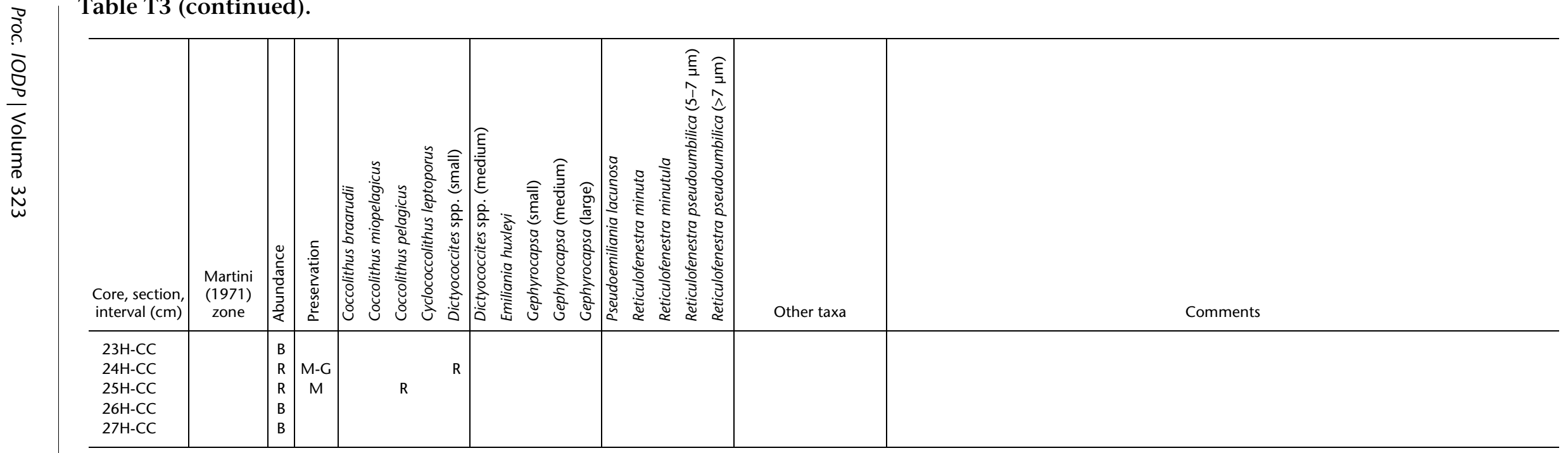

Notes: Abundance: $\mathrm{D}=$ dominant, $\mathrm{A}=$ abundant $\mathrm{C}=$ common, $\mathrm{F}=$ few, $\mathrm{R}=$ rare, $\mathrm{B}=$ barren,$-=$ no sample. Preservation: $\mathrm{G}=$ good, $\mathrm{M}=\mathrm{moderate}, \mathrm{P}=$ poor. $\mathrm{FOV}=$ field of view. 
Table T4. Planktonic foraminifer range chart, Holes U1341A, U1341B, and U1341C. (See table notes.) (Continued on next two pages.)

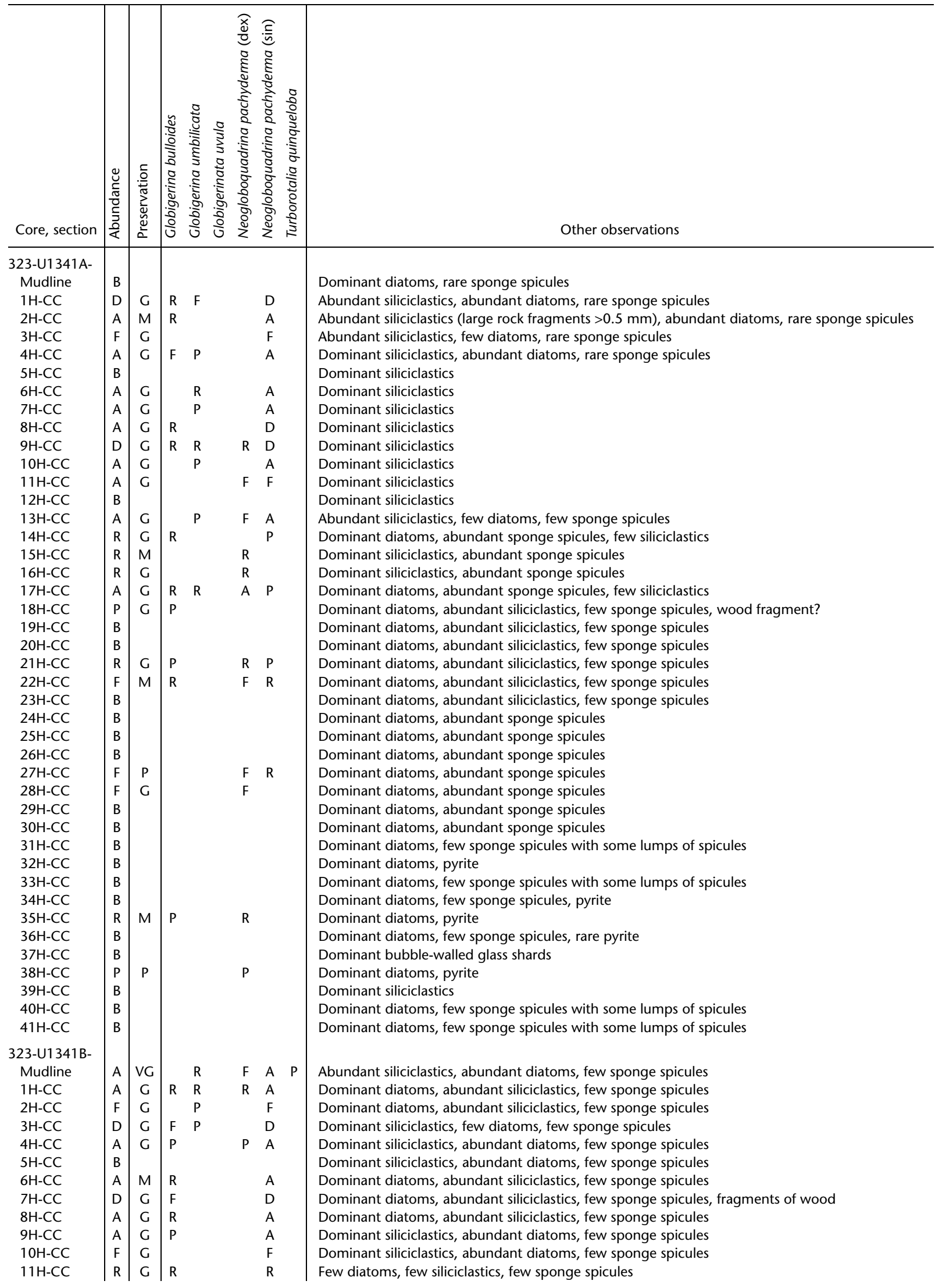


Table T4 (continued). (Continued on next page.)

\begin{tabular}{|c|c|c|c|c|c|c|c|c|}
\hline Core, section & 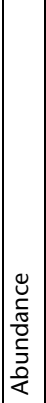 & 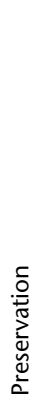 & 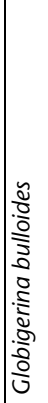 & 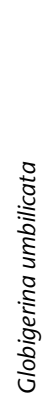 & 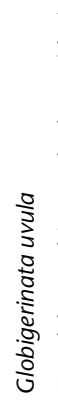 & 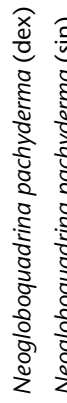 & 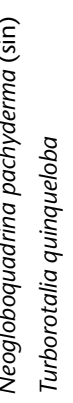 & Other observations \\
\hline $12 \mathrm{H}-\mathrm{CC}$ & $A$ & G & & & & & A & Dominant siliciclastics, abundant diatoms, few sponge spicules \\
\hline $13 \mathrm{H}-\mathrm{CC}$ & $P$ & G & & & & $P$ & $\mathrm{P}$ & Dominant siliciclastics, abundant diatoms, few sponge spicules \\
\hline $14 \mathrm{H}-\mathrm{CC}$ & $\mathrm{R}$ & G & & & & $\mathrm{R}$ & $\mathrm{R}$ & Dominant siliciclastics, abundant diatoms, few sponge spicules \\
\hline $15 \mathrm{H}-\mathrm{CC}$ & B & & & & & & & Dominant siliciclastics, abundant diatoms, few sponge spicules \\
\hline $16 \mathrm{H}-\mathrm{CC}$ & $\mathrm{F}$ & M & $\mathrm{R}$ & & & $\mathrm{F}$ & & Dominant siliciclastics, abundant diatoms, few sponge spicules \\
\hline $17 \mathrm{H}-\mathrm{CC}$ & $\mathrm{F}$ & G & $\mathrm{F}$ & $\mathrm{F}$ & $\mathrm{R}$ & $\mathrm{R}$ & & Dominant diatoms, abundant siliciclastics, few sponge spicules \\
\hline $18 \mathrm{H}-\mathrm{CC}$ & B & & & & & & & Dominant diatoms, abundant siliciclastics, few sponge spicules \\
\hline $19 \mathrm{H}-\mathrm{CC}$ & B & & & & & & & Dominant diatoms, abundant siliciclastics, few sponge spicules \\
\hline $20 \mathrm{H}-\mathrm{CC}$ & B & & & & & & & Abundant sponge spicules \\
\hline $21 \mathrm{H}-\mathrm{CC}$ & B & & & & & & & Dominant diatoms, abundant siliciclastics, few sponge spicules \\
\hline $22 \mathrm{H}-\mathrm{CC}$ & B & & & & & & & Dominant diatoms, abundant siliciclastics, few sponge spicules \\
\hline $23 \mathrm{H}-\mathrm{CC}$ & $\mathrm{P}$ & $P$ & & & & & $P$ & Dominant siliciclastics, abundant diatoms, few sponge spicules \\
\hline $24 \mathrm{H}-\mathrm{CC}$ & B & & & & & & & Dominant diatoms, few siliciclastics, few sponge spicules \\
\hline $25 \mathrm{H}-\mathrm{CC}$ & $P$ & G & $\mathrm{P}$ & & & $P$ & & Dominant diatoms, few siliciclastics, abundant sponge spicules \\
\hline $26 \mathrm{H}-\mathrm{CC}$ & A & M & $\mathrm{F}$ & & & A & $\mathrm{R}$ & Dominant diatoms, few siliciclastics, few sponge spicules \\
\hline $27 \mathrm{H}-\mathrm{CC}$ & B & & & & & & & Dominant diatoms, few siliciclastics, abundant sponge spicules \\
\hline $28 \mathrm{H}-\mathrm{CC}$ & $\mathrm{R}$ & M & $\mathrm{R}$ & & & & $P$ & Dominant siliciclastics, abundant diatoms, few sponge spicules \\
\hline $29 \mathrm{H}-\mathrm{CC}$ & B & & & & & & & Dominant diatoms, few siliciclastics, abundant sponge spicules \\
\hline $30 \mathrm{H}-\mathrm{CC}$ & B & & & & & & & Dominant diatoms, few siliciclastics, abundant sponge spicules with some lumps of spicules \\
\hline $31 \mathrm{H}-\mathrm{CC}$ & B & & & & & & & Dominant bubble-walled glass shards, abundant sponge spicules with some lumps of spicules \\
\hline $32 \mathrm{H}-\mathrm{CC}$ & B & & & & & & & Dominant siliciclastics, abundant diatoms, few sponge spicules with some lumps of spicules \\
\hline $33 \mathrm{H}-\mathrm{CC}$ & B & & & & & & & Abundant diatoms and sponge spicules with lumps of spicules \\
\hline $34 \mathrm{H}-\mathrm{CC}$ & B & & & & & & & Dominant siliciclastics, abundant diatoms, few sponge spicules with some lumps of spicules \\
\hline $35 \mathrm{H}-\mathrm{CC}$ & B & & & & & & & Dominant siliciclastics, abundant diatoms, few sponge spicules with some lumps of spicules \\
\hline $36 \mathrm{H}-\mathrm{CC}$ & $\mathrm{F}$ & G & $\mathrm{R}$ & $\mathrm{R}$ & $\mathrm{F}$ & $\mathrm{F}$ & & Dominant foraminifers, few sponge spicules \\
\hline $37 \mathrm{H}-\mathrm{CC}$ & B & & & & & & & Abundant diatoms and sponge spicules with lumps of spicules \\
\hline $38 \mathrm{H}-\mathrm{CC}$ & B & & & & & & & Abundant diatoms and sponge spicules with lumps of spicules \\
\hline $39 \mathrm{H}-\mathrm{CC}$ & B & & & & & & & Abundant diatoms and sponge spicules with lumps of spicules \\
\hline $40 \mathrm{H}-\mathrm{CC}$ & B & & & & & & & Abundant diatoms and sponge spicules with lumps of spicules \\
\hline $41 \mathrm{H}-\mathrm{CC}$ & B & & & & & & & Abundant diatoms and sponge spicules with lumps of spicules \\
\hline $42 \mathrm{H}-\mathrm{CC}$ & B & & & & & & & Abundant diatoms and sponge spicules with lumps of spicules \\
\hline $43 \mathrm{H}-\mathrm{CC}$ & B & & & & & & & Abundant diatoms and sponge spicules with lumps of spicules \\
\hline $44 \mathrm{H}-\mathrm{CC}$ & B & & & & & & & Abundant diatoms and sponge spicules with lumps of spicules \\
\hline $45 \mathrm{H}-\mathrm{CC}$ & B & & & & & & & Abundant diatoms and sponge spicules with lumps of spicules \\
\hline $46 \mathrm{H}-\mathrm{CC}$ & B & & & & & & & Abundant diatoms and sponge spicules with lumps of spicules \\
\hline $47 \mathrm{H}-\mathrm{CC}$ & B & & & & & & & Dominant diatoms, few siliciclastics, rare sponge spicules \\
\hline $48 \mathrm{H}-\mathrm{CC}$ & B & & & & & & & Dominant diatoms, rare sponge spicules \\
\hline $49 \mathrm{H}-\mathrm{CC}$ & B & & & & & & & Dominant diatoms, abundant siliciclastics, rare sponge spicules \\
\hline $50 \mathrm{H}-\mathrm{CC}$ & B & & & & & & & Dominant diatoms, abundant siliciclastics, few sponge spicules \\
\hline $51 \mathrm{H}-\mathrm{CC}$ & B & & & & & & & Dominant diatoms, abundant siliciclastics, few sponge spicules \\
\hline $52 \mathrm{H}-\mathrm{CC}$ & B & & & & & & & Dominant diatoms, abundant siliciclastics, few sponge spicules \\
\hline $53 \mathrm{H}-\mathrm{CC}$ & $\mathrm{B}$ & & & & & & & Dominant diatoms, abundant siliciclastics, few sponge spicules \\
\hline $54 \mathrm{H}-\mathrm{CC}$ & $\mathrm{B}$ & & & & & & & Dominant diatoms, abundant siliciclastics, few sponge spicules \\
\hline $55 \mathrm{H}-\mathrm{CC}$ & B & & & & & & & Dominant diatoms, abundant siliciclastics, few sponge spicules \\
\hline $56 \mathrm{H}-\mathrm{CC}$ & B & & & & & & & Dominant diatoms, abundant siliciclastics, few sponge spicules \\
\hline $57 X-C C$ & B & & & & & & & Dominant diatoms, abundant siliciclastics, few sponge spicules \\
\hline $58 \mathrm{X}-\mathrm{CC}$ & B & & & & & & & Dominant bubble-walled glass shards \\
\hline $59 \mathrm{X}-\mathrm{CC}$ & B & & & & & & & Dominant diatoms, abundant siliciclastics, rare sponge spicules \\
\hline $60 \mathrm{X}-\mathrm{CC}$ & B & & & & & & & Dominant diatoms, abundant siliciclastics, rare sponge spicules \\
\hline $61 X-C C$ & $\mathrm{R}$ & G & $\mathrm{R}$ & & & & & Dominant diatoms, abundant siliciclastics, rare sponge spicules \\
\hline $62 \mathrm{X}-\mathrm{CC}$ & B & & & & & & & Dominant diatoms, abundant siliciclastics, rare sponge spicules \\
\hline $63 \mathrm{X}-\mathrm{CC}$ & B & & & & & & & Dominant diatoms, abundant siliciclastics, rare sponge spicules \\
\hline $64 \mathrm{X}-\mathrm{CC}$ & $\mathrm{B}$ & & & & & & & Dominant diatoms, abundant siliciclastics, rare sponge spicules \\
\hline $65 \mathrm{X}-\mathrm{CC}$ & $\mathrm{B}$ & & & & & & & Dominant diatoms, abundant siliciclastics, rare sponge spicules \\
\hline $66 \mathrm{X}-\mathrm{CC}$ & B & & & & & & & Dominant diatoms, abundant siliciclastics, rare sponge spicules \\
\hline $67 \mathrm{X}-\mathrm{CC}$ & B & & & & & & & Dominant diatoms, abundant siliciclastics, rare sponge spicules \\
\hline $68 \mathrm{X}-\mathrm{CC}$ & B & & & & & & & Dominant diatoms, abundant siliciclastics, rare sponge spicules \\
\hline $69 X-C C$ & B & & & & & & & Dominant diatoms, few siliciclastics, rare sponge spicules \\
\hline
\end{tabular}


Table T4 (continued).

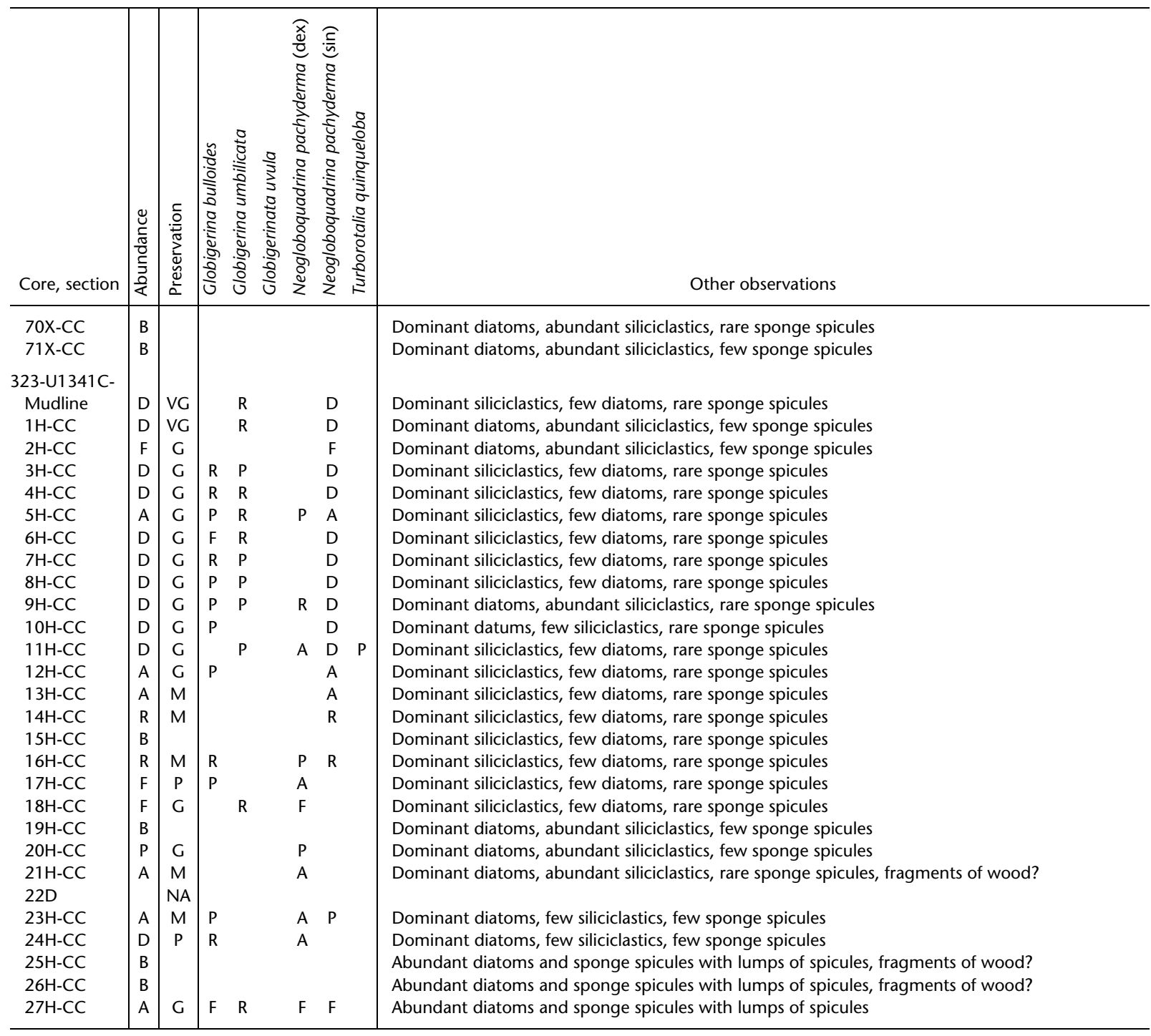

Notes: Abundance: $\mathrm{D}=$ dominant, $\mathrm{A}=$ abundant, $\mathrm{F}=$ few $\mathrm{R}=$ rare, $\mathrm{P}=$ present, $\mathrm{B}=$ barren. Preservation: $\mathrm{VG}=$ very good, $\mathrm{G}=$ good, $\mathrm{M}=\mathrm{moder}-$ ate, $\mathrm{P}=$ poor, $\mathrm{NA}=$ not applicable. $\mathrm{Dex}=$ dextral, $\sin =$ sinistral. 
Table T5. Benthic foraminifer and ostracode range chart, Hole U1341A. (See table notes.)

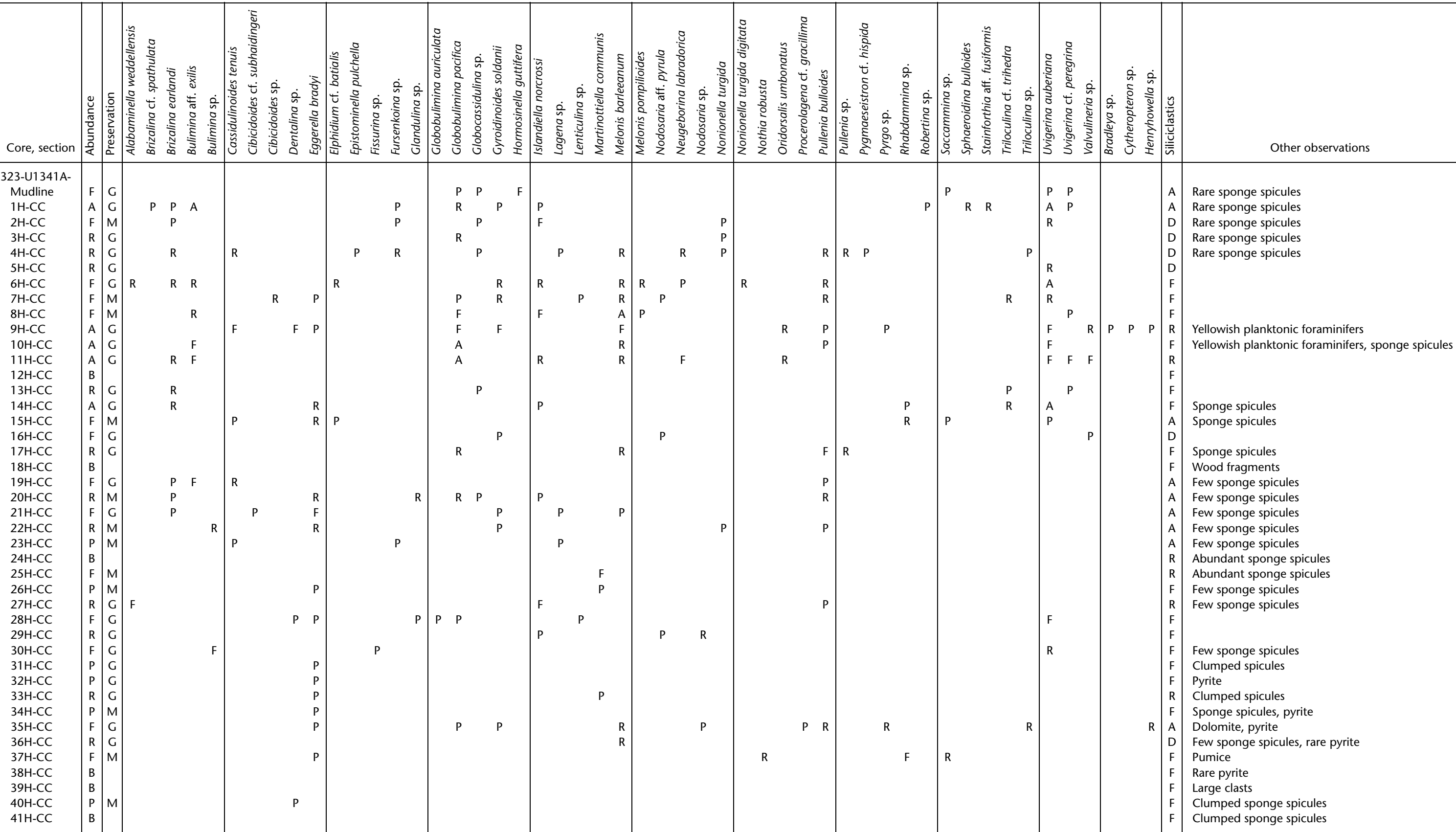


Table T6. Benthic foraminifer range chart, Hole U1341B. This table is available in an oversized format. 
Table T7. Benthic foraminifer range chart, Hole U1341C. (See table notes.)

Notes: Abundance: $D=$ dominant, $A=$ abundant, $F=$ few, $R=$ rare, $P=$ present, $B=$ barren. Preservation: $V G=$ very good, $G=$ good, $M=$ moderate, $P=$ poor. 
Table T8. Diatom range chart, Hole U1341A. (See table notes.)

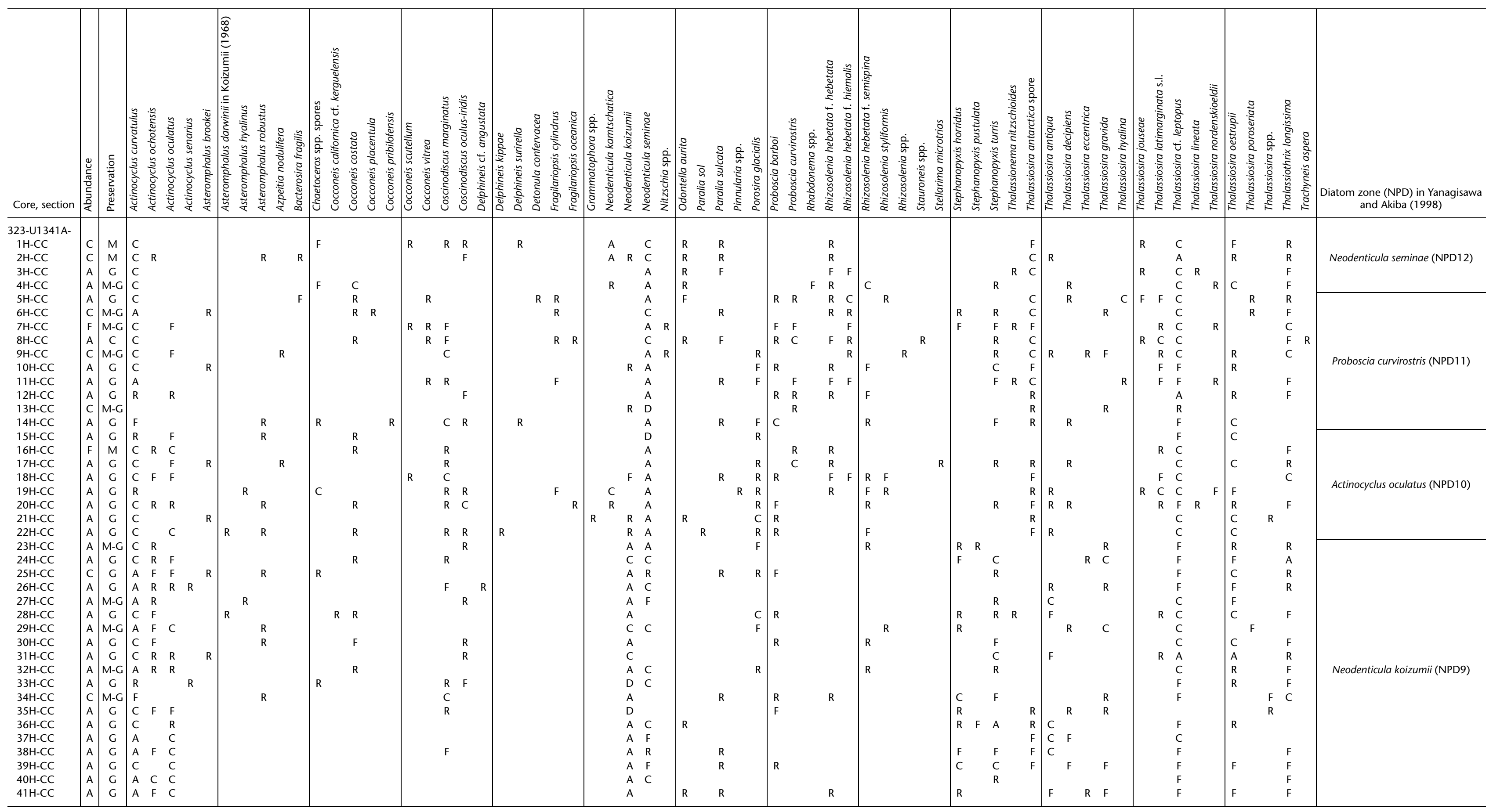

Notes: Abundance: $\mathrm{D}=$ dominant, $\mathrm{A}=$ abundant, $\mathrm{C}=$ common, $\mathrm{F}=$ few, $\mathrm{R}=$ rare. Preservation: $\mathrm{G}=$ good, $\mathrm{M}=$ moderate 
Table T9. Diatom range chart, Hole U1341B. This table is available in an oversized format.

Table T10. Silicoflagellate and ebridian range chart, Hole U1341A. (See table notes.)

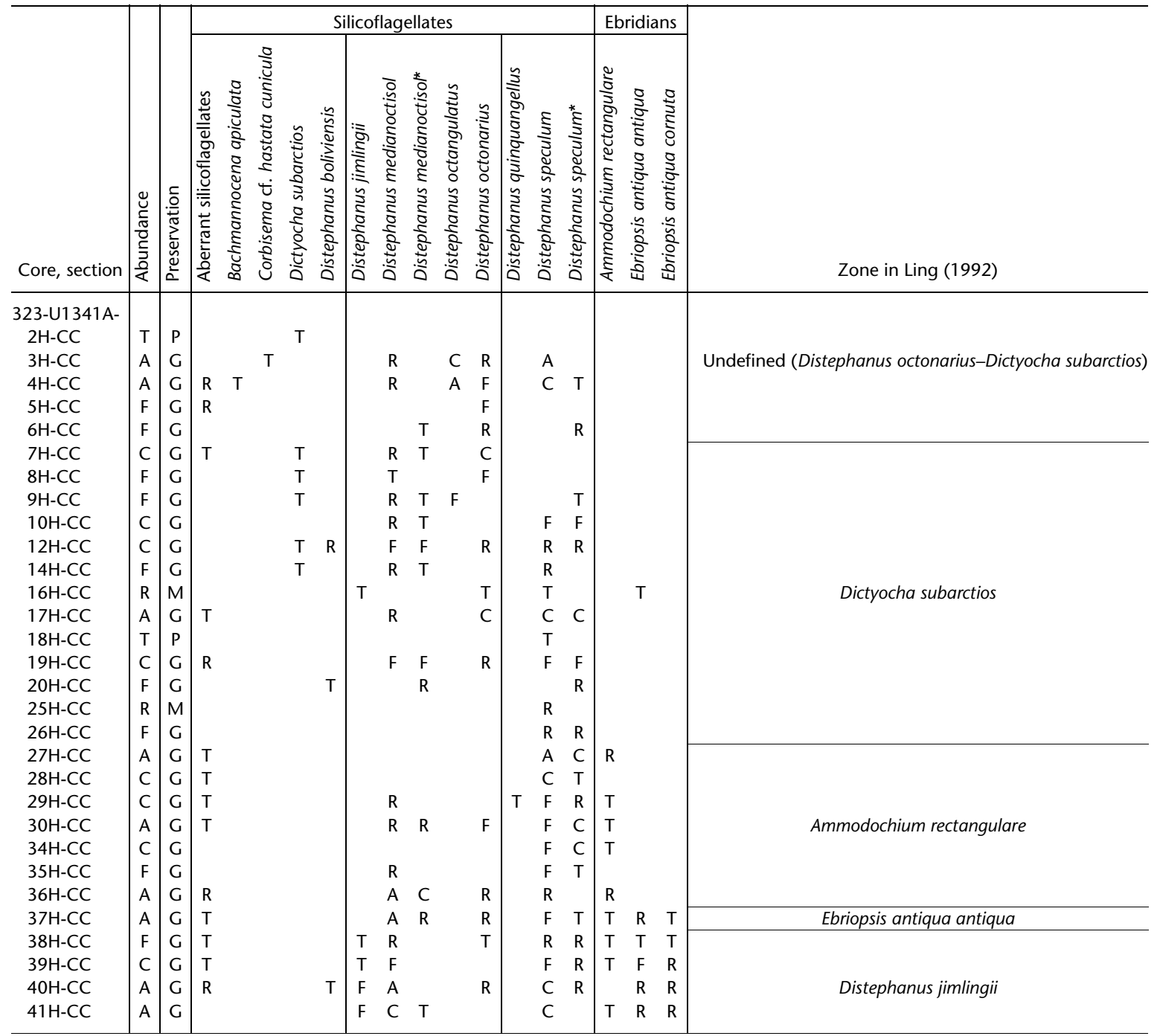

Notes: * $=$ with short radial spines. Abundance: $A=$ abundant, $C=$ common, $F=f e w, R=$ rare, $T=$ trace. Preservation: $G=$ good, $M=$ moderate, $\mathrm{P}=$ poor. 
Table T11. Silicoflagellate and ebridian range chart, Hole U1341B. (See table notes.)

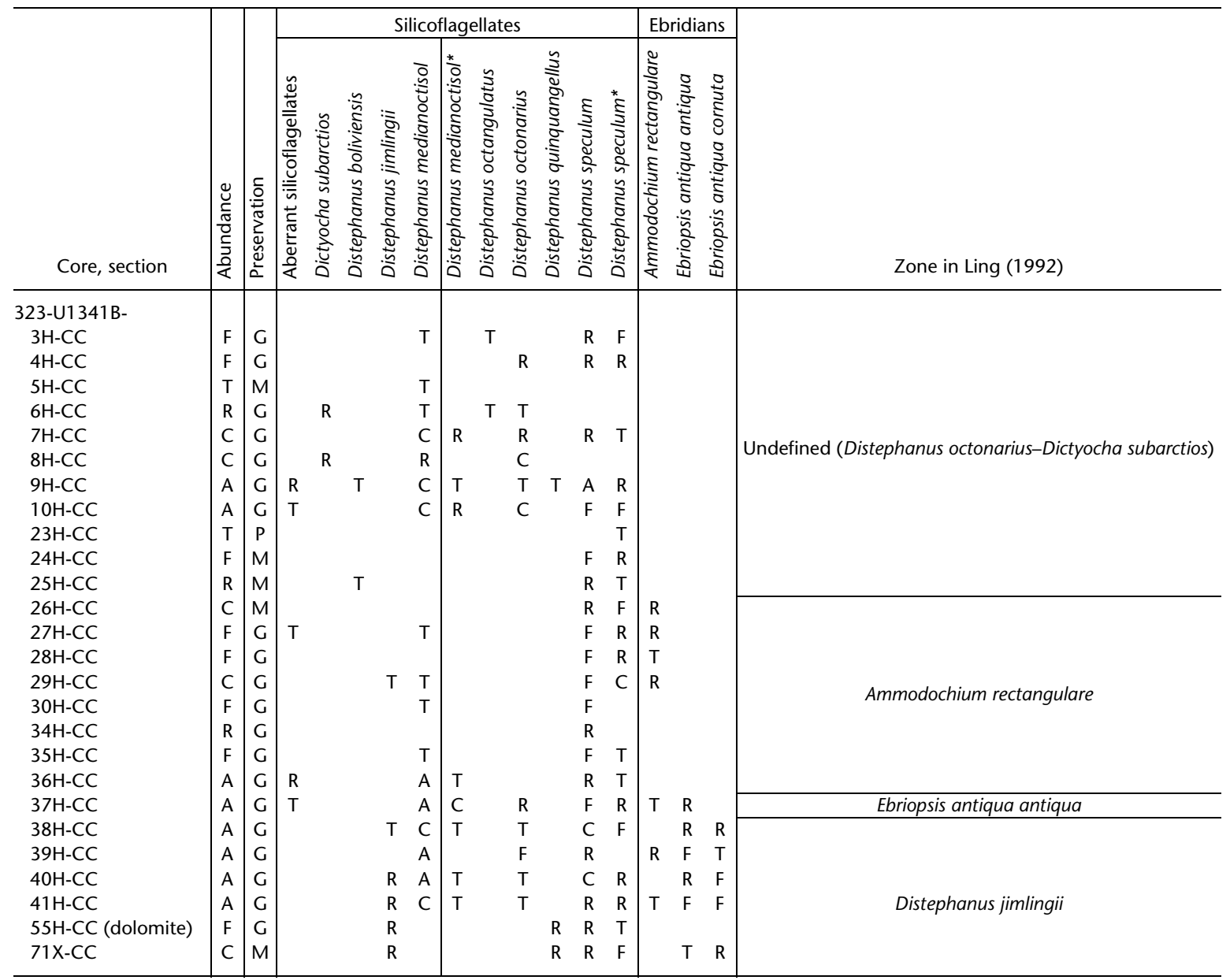

Notes: * $=$ with short radial spines. Abundance: $A=$ abundant, $C=$ common, $F=f e w, R=$ rare, $T=$ trace. Preservation: $G=$ good, $M=$ moderate, $\mathrm{P}=$ poor. 
Table T12. Radiolarian datum events, Holes U1341A, U1341B, and U1341C. (See table note.)

\begin{tabular}{|c|c|c|c|c|c|c|c|c|c|c|c|c|c|c|}
\hline \multirow[b]{3}{*}{ Zone } & \multirow[b]{3}{*}{ Marker species } & \multirow[b]{3}{*}{ Age (Ma) } & \multicolumn{4}{|c|}{ Hole U1341A } & \multicolumn{4}{|c|}{ Hole U1341B } & \multicolumn{4}{|c|}{ Hole U1341C } \\
\hline & & & \multicolumn{2}{|c|}{ Core, section } & \multicolumn{2}{|c|}{ Depth (mbsf) } & \multicolumn{2}{|c|}{ Core, section } & \multicolumn{2}{|c|}{ Depth (mbsf) } & \multicolumn{2}{|c|}{ Core, section } & \multicolumn{2}{|c|}{ Depth (mbsf) } \\
\hline & & & Top & Bottom & Top & Bottom & Top & Bottom & Top & Bottom & Top & Bottom & Top & Bottom \\
\hline \multirow{4}{*}{ Botryostrobus aquilonaris } & T Lychnocanoma nipponica sakaii & 0.05 & $1 \mathrm{H}-\mathrm{CC}$ & $2 \mathrm{H}-\mathrm{CC}$ & 3.02 & 12.64 & \multirow{4}{*}{$1 \mathrm{H}-\mathrm{CC}$} & $1 \mathrm{H}-\mathrm{CC}$ & 0.00 & 8.72 & $1 \mathrm{H}-\mathrm{CC}$ & $2 \mathrm{H}-\mathrm{CC}$ & 5.5 & 15.4 \\
\hline & T Amphimelissa setosa & $0.08-0.10$ & $1 \mathrm{H}-\mathrm{CC}$ & $2 \mathrm{H}-\mathrm{CC}$ & 3.02 & 12.64 & & \multirow[t]{3}{*}{$2 \mathrm{H}-\mathrm{CC}$} & 8.72 & 18.58 & $2 \mathrm{H}-\mathrm{CC}$ & $3 \mathrm{H}-\mathrm{CC}$ & 15.4 & 24.9 \\
\hline & T Spongodiscus sp. & $0.28-0.32$ & $4 \mathrm{H}-\mathrm{CC}$ & $5 \mathrm{H}-\mathrm{CC}$ & 31.77 & 41.32 & & & 37.70 & 47.18 & $6 \mathrm{H}-\mathrm{CC}$ & 7H-CC & 53.6 & 62.2 \\
\hline & T Axoprunum acquilonium & $0.25-0.43$ & $6 \mathrm{H}-\mathrm{CC}$ & $7 \mathrm{H}-\mathrm{CC}$ & 50.95 & 60.51 & & & 56.68 & 66.18 & 7H-CC & $8 \mathrm{H}-\mathrm{CC}$ & 62.2 & 71.1 \\
\hline Stylatractus universus & T Stylatractus universus & $0.41-0.51$ & $13 \mathrm{H}-\mathrm{CC}$ & $14 \mathrm{H}-\mathrm{CC}$ & 117.70 & 127.10 & \multicolumn{2}{|c|}{ Not found } & & & $6 \mathrm{H}-\mathrm{CC}$ & $7 \mathrm{H}-\mathrm{CC}$ & 53.6 & 62.2 \\
\hline \multirow{2}{*}{ Eucyrtidium matuyamai } & T Eucyrtidium matuyamai & $0.9-1.5$ & $13 \mathrm{H}-\mathrm{CC}$ & $14 \mathrm{H}-\mathrm{CC}$ & 117.70 & 127.10 & $11 \mathrm{H}-\mathrm{CC}$ & $12 \mathrm{H}-\mathrm{CC}$ & 104.25 & 113.59 & $16 \mathrm{H}-\mathrm{CC}$ & $17 \mathrm{H}-\mathrm{CC}$ & 139.7 & 147.2 \\
\hline & B Eucyrtidium matuyamai & $1.7-1.9$ & $15 \mathrm{H}-\mathrm{CC}$ & $16 \mathrm{H}-\mathrm{CC}$ & 136.26 & 146.07 & $15 \mathrm{H}-\mathrm{CC}$ & $16 \mathrm{H}-\mathrm{CC}$ & 142.36 & 151.68 & $19 \mathrm{H}-\mathrm{CC}$ & $20 \mathrm{H}-\mathrm{CC}$ & 166.6 & 176.1 \\
\hline Cycladophora sakaii & T Thecosphaera akitaensis & $2.4-2.7$ & & & & & $46 \mathrm{H}-\mathrm{CC}$ & $47 \mathrm{H}-\mathrm{CC}$ & 413.70 & 414.53 & & & & \\
\hline Dictyophimus bullatus & T Dictyophimus bullatus & $3.8-4.0$ & & & & & $70 \mathrm{X}-\mathrm{CC}$ & $71 \mathrm{X}-\mathrm{CC}$ & 592.25 & 601.87 & & & & \\
\hline
\end{tabular}

Note: $\mathrm{T}=$ top, $\mathrm{B}=$ bottom.

Table T13. Radiolarian range chart, Holes U1341A, U1341B, and U1341C. (See table notes.) (Continued on next three pages.)

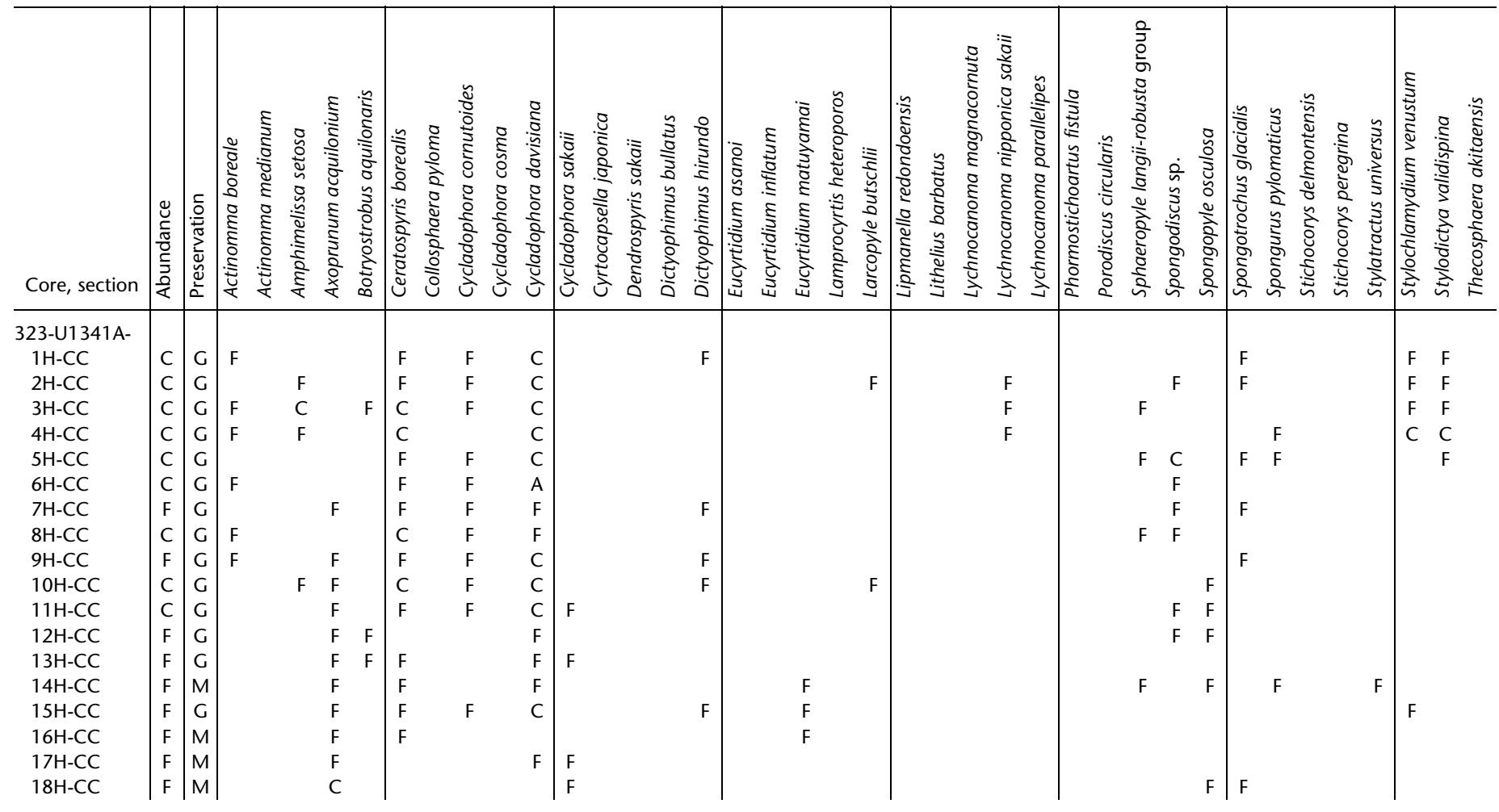


Table T13 (continued). (Continued on next page.)

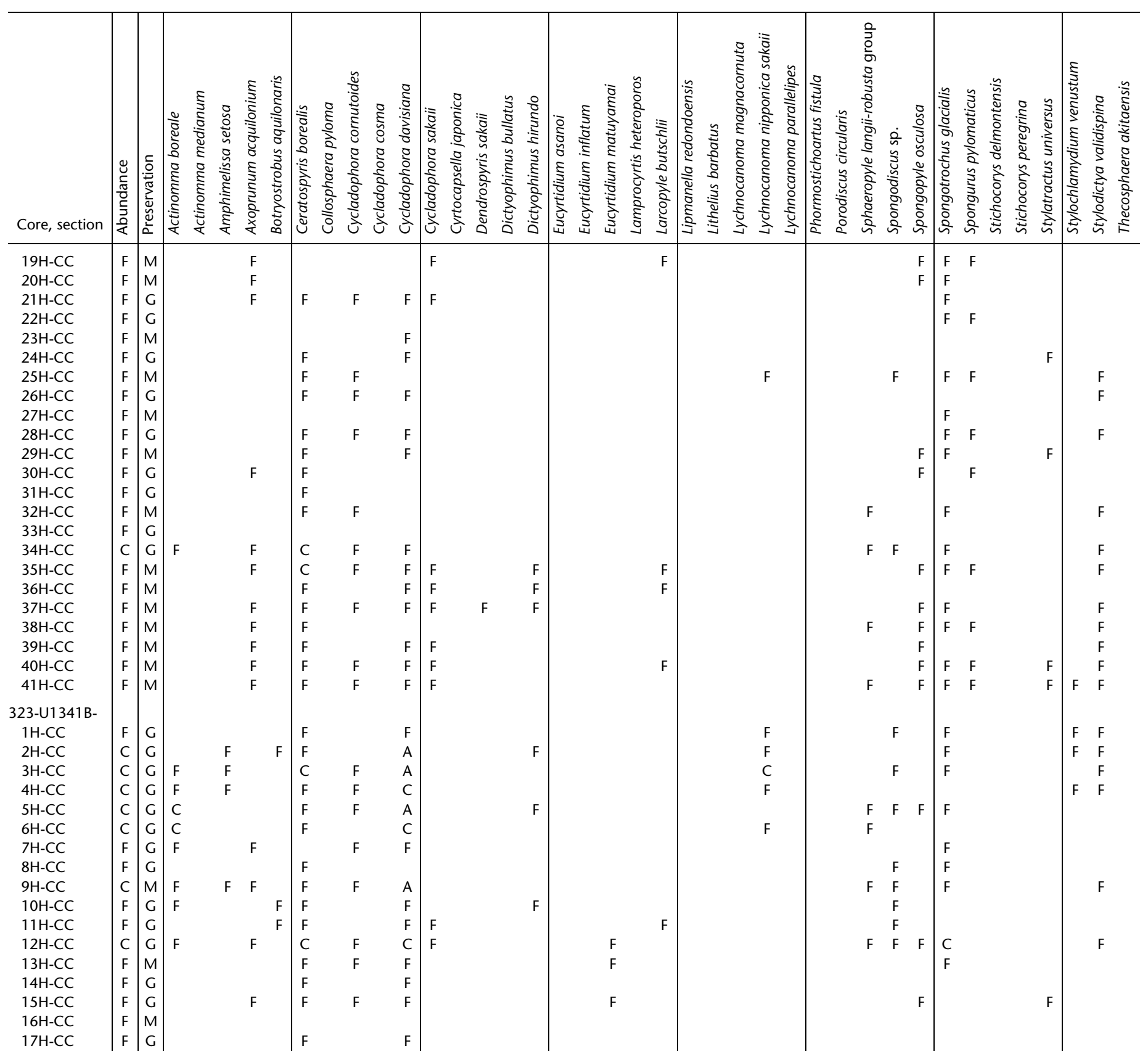


Table T13 (continued). (Continued on next page.)
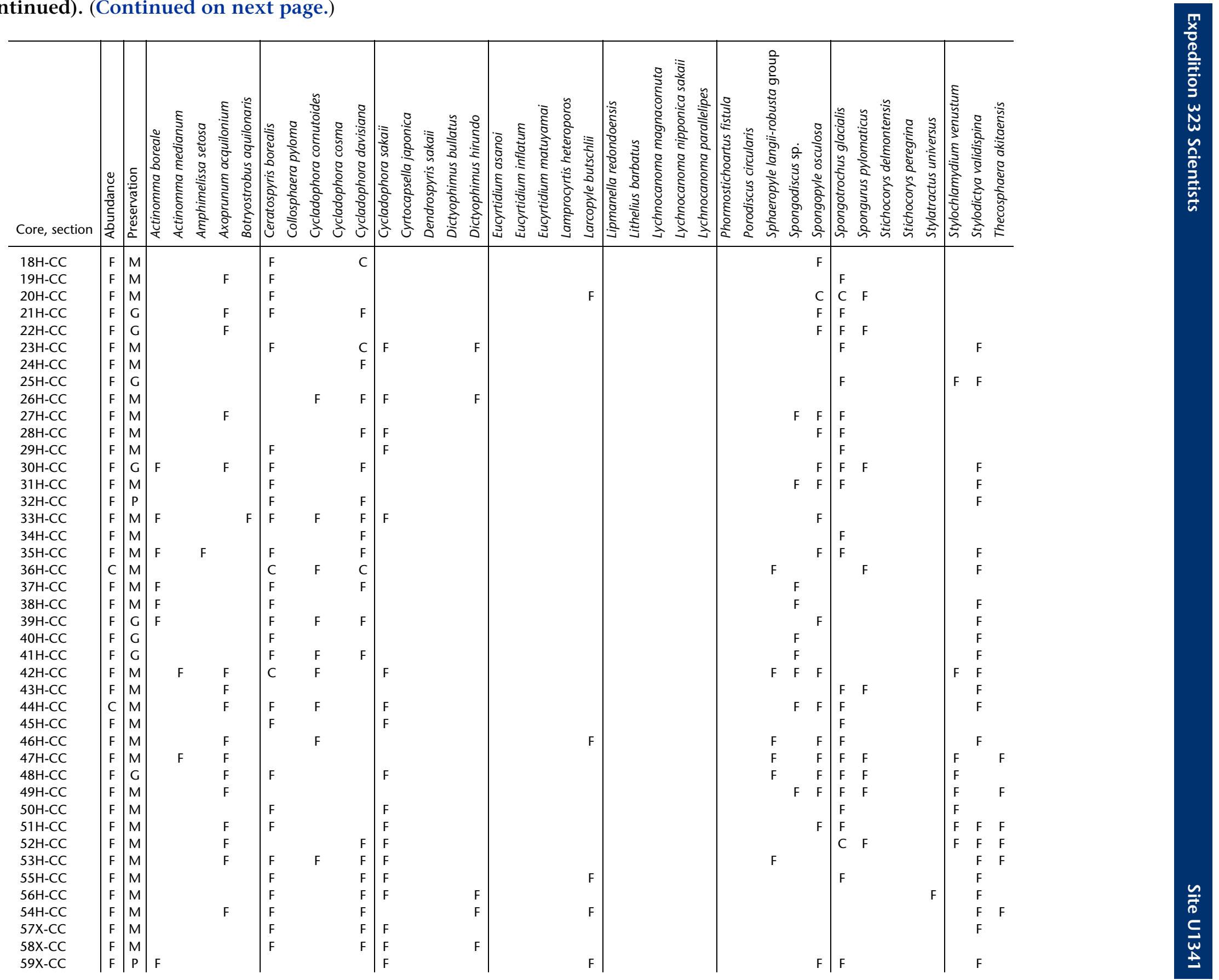
Table T13 (continued).

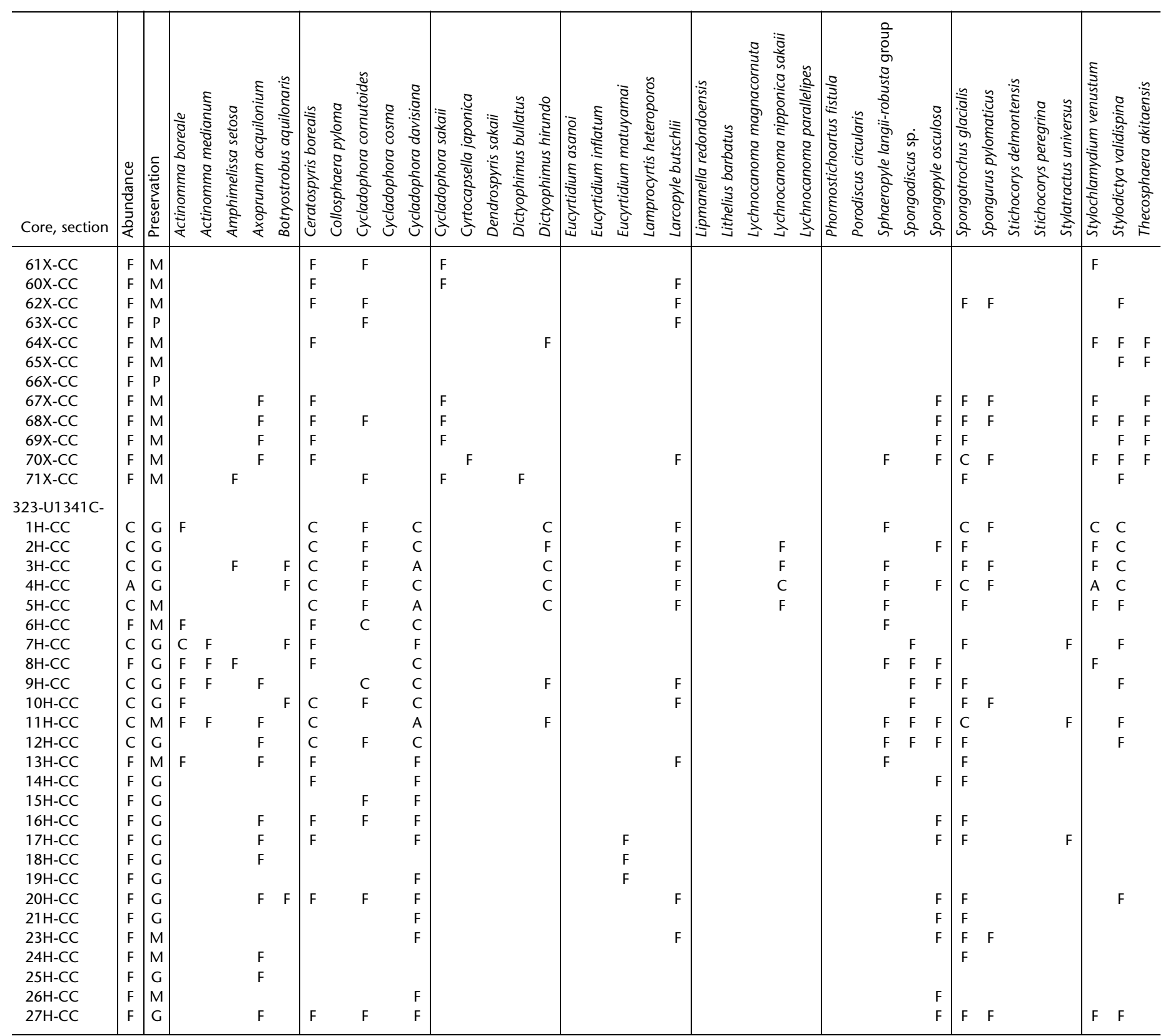


Table T14. Dinoflagellate cyst, pollen, and palynomorph range chart, Holes U1341A and U1341B. (See table notes.)

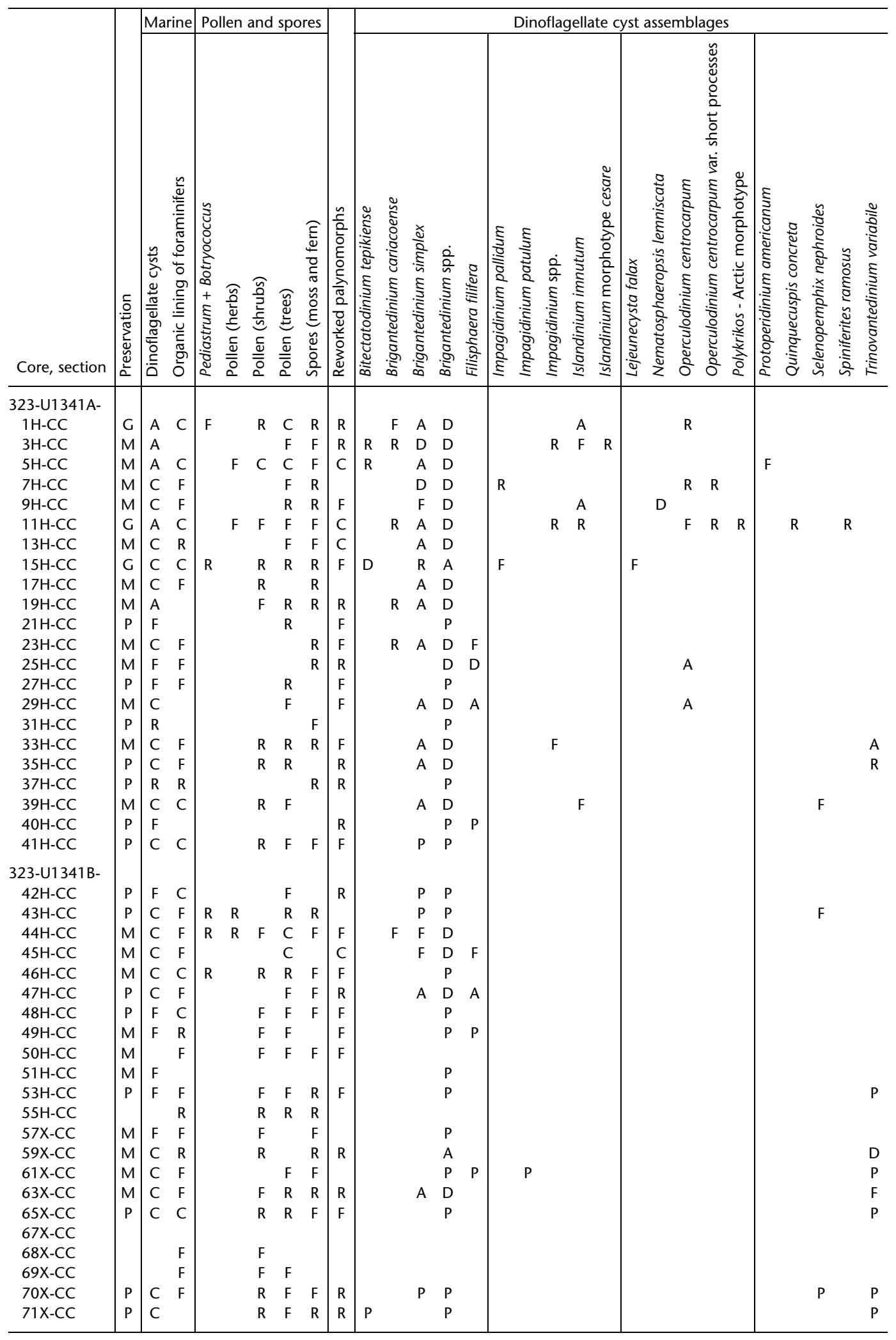

Notes: Preservation: $\mathrm{G}=$ good, $\mathrm{M}=$ moderate, $\mathrm{P}=$ poor. Absolute abundance: $\mathrm{A}=$ abundant $\left(>2000 / \mathrm{cm}^{3}\right), \mathrm{C}=\mathrm{common}\left(>200 / \mathrm{cm}^{3}\right), \mathrm{F}=\mathrm{few}$ $\left(>20 / \mathrm{cm}^{3}\right), \mathrm{R}=$ rare $\left(<20 / \mathrm{cm}^{3}\right)$. Relative abundance of dinoflagellate cysts: $\mathrm{D}=$ dominant $(>30 \%), \mathrm{A}=$ abundant $(>10 \%), \mathrm{F}=\mathrm{few}(>5 \%), \mathrm{R}=$ rare $(<2 \%), P=$ occurrence (when counts are $<20$ ). 
Table T15. Chron ages and preliminary depths, Holes U1341A, U1341B, and U1341C. (See table notes.)

\begin{tabular}{|c|c|c|c|c|c|c|c|c|c|c|}
\hline \multirow[b]{2}{*}{ Event } & \multirow[b]{2}{*}{$\begin{array}{l}\text { Age } \\
(\mathrm{ka})\end{array}$} & \multicolumn{3}{|c|}{ Hole U1341A } & \multicolumn{3}{|c|}{ Hole U1341B } & \multicolumn{3}{|c|}{ Hole U1341C } \\
\hline & & $\begin{array}{l}\text { Core, section, } \\
\text { interval }(\mathrm{cm})\end{array}$ & $\begin{array}{l}\text { Depth } \\
\text { (mbsf) }\end{array}$ & $\begin{array}{l}\text { Sed. rate } \\
(\mathrm{cm} / \mathrm{k} \cdot \mathrm{y} .)\end{array}$ & $\begin{array}{l}\text { Core, section, } \\
\text { interval }(\mathrm{cm})\end{array}$ & $\begin{array}{l}\text { Depth } \\
\text { (mbsf) }\end{array}$ & $\begin{array}{l}\text { Sed. rate } \\
(\mathrm{cm} / \mathrm{k} . \mathrm{y} .)\end{array}$ & $\begin{array}{l}\text { Core, section, } \\
\text { interval }(\mathrm{cm})\end{array}$ & $\begin{array}{l}\text { Depth } \\
\text { (mbsf) }\end{array}$ & $\begin{array}{l}\text { Sed. rate } \\
(\mathrm{cm} / \mathrm{k} . \mathrm{y} .)\end{array}$ \\
\hline & & 323-U1341A- & & & 323-U1341B- & & & 323-U1341C- & & \\
\hline & 0 & & 0 & 10.6 & & 0 & 10.6 & & & 10.3 \\
\hline B Brunhes & 781 & $10 \mathrm{H}-3,50$ & 82.5 & 11.6 & $9 \mathrm{H}-5,130$ & 82.5 & 9.8 & $10 \mathrm{H}-1,30$ & 80.3 & 10.9 \\
\hline T Jaramillo & 998 & $12 \mathrm{H}-7,65$ & 107.65 & 38.3 & $12 \mathrm{H}(\mathrm{T})$ & 103.7 & 46.4 & $12 \mathrm{H}-6,100$ & 104 & 45.7 \\
\hline B Jaramillo & 1072 & $16 \mathrm{H}-1$ & 136 & & $15 \mathrm{H}-4,130$ & 138 & 15.2 & $16 \mathrm{H}-3,130$ & 137.8 & \\
\hline T Gauss & 2581 & & & & $42 \mathrm{H}(\mathrm{T})$ & 367.8 & & & & \\
\hline
\end{tabular}

Notes: $\mathrm{B}=$ bottom, $\mathrm{T}=$ top. Sed. rate $=$ sedimentation rate.

Table T16. Moisture and density, Hole U1341B. (Continued on next two pages.)

\begin{tabular}{|c|c|c|c|c|c|c|c|}
\hline \multirow{2}{*}{$\begin{array}{l}\text { Core, section, } \\
\text { interval }(\mathrm{cm})\end{array}$} & \multirow{2}{*}{$\begin{array}{l}\text { Depth } \\
\text { (mbsf) }\end{array}$} & \multicolumn{3}{|c|}{ Density $\left(\mathrm{g} / \mathrm{cm}^{3}\right)$} & \multirow{2}{*}{$\begin{array}{l}\text { Void } \\
\text { ratio }\end{array}$} & \multirow{2}{*}{$\begin{array}{l}\text { Water } \\
\text { content } \\
(\%)\end{array}$} & \multirow{2}{*}{$\begin{array}{c}\text { Porosity } \\
(\%)\end{array}$} \\
\hline & & Dry grain & Wet bulk & Dry bulk & & & \\
\hline \multicolumn{8}{|l|}{ 323-U1341B- } \\
\hline 2H-1, 29-31 & 9.0 & 2.76 & 1.35 & 0.55 & 4.39 & 59.4 & 81.4 \\
\hline $2 \mathrm{H}-3,29-31$ & 12.0 & 1.72 & 1.23 & 0.54 & 2.28 & 55.8 & 69.5 \\
\hline $2 \mathrm{H}-5,29-31$ & 15.0 & 2.67 & 1.37 & 0.59 & 3.78 & 56.9 & 79.1 \\
\hline $3 \mathrm{H}-1,29-31$ & 18.5 & 2.32 & 1.20 & 0.35 & 6.28 & 70.8 & 86.3 \\
\hline $3 \mathrm{H}-3,29-31$ & 21.5 & 2.64 & 1.44 & 0.70 & 2.92 & 51.1 & 74.5 \\
\hline $3 \mathrm{H}-5,29-31$ & 24.5 & 2.63 & 1.42 & 0.68 & 3.06 & 52.3 & 75.4 \\
\hline $4 \mathrm{H}-1,29-31$ & 28.0 & 2.73 & 1.46 & 0.73 & 2.94 & 50.4 & 74.6 \\
\hline $4 \mathrm{H}-3,29-31$ & 31.0 & 2.23 & 1.22 & 0.40 & 5.04 & 67.4 & 83.4 \\
\hline $4 \mathrm{H}-5,29-31$ & 34.0 & 2.77 & 1.54 & 0.85 & 2.40 & 45.2 & 70.6 \\
\hline $5 \mathrm{H}-1,29-31$ & 37.5 & 2.50 & 1.41 & 0.68 & 2.86 & 52.0 & 74.1 \\
\hline $5 \mathrm{H}-5,29-31$ & 43.5 & 2.23 & 1.34 & 0.62 & 2.78 & 54.1 & 73.6 \\
\hline $6 \mathrm{H}-1,29-31$ & 47.0 & 2.63 & 1.39 & 0.63 & 3.43 & 55.0 & 77.4 \\
\hline $6 \mathrm{H}-3,29-31$ & 50.0 & 2.12 & 1.16 & 0.30 & 6.94 & 74.4 & 87.4 \\
\hline $6 \mathrm{H}-5,29-31$ & 53.0 & 2.57 & 1.32 & 0.52 & 4.30 & 60.7 & 81.1 \\
\hline $7 \mathrm{H}-1,29-31$ & 56.5 & 2.45 & 1.34 & 0.57 & 3.52 & 57.3 & 77.9 \\
\hline $7 \mathrm{H}-3,29-31$ & 59.5 & 2.44 & 1.27 & 0.46 & 4.71 & 63.9 & 82.5 \\
\hline 7H-5, 29-31 & 62.5 & 2.37 & 1.31 & 0.53 & 3.71 & 59.4 & 78.8 \\
\hline $8 \mathrm{H}-1,29-31$ & 66.0 & 2.58 & 1.34 & 0.55 & 3.99 & 58.9 & 80.0 \\
\hline $8 \mathrm{H}-3,29-31$ & 69.0 & 2.07 & 1.24 & 0.46 & 3.73 & 62.6 & 78.9 \\
\hline $8 \mathrm{H}-5,29-31$ & 72.0 & 2.45 & 1.24 & 0.41 & 5.58 & 67.4 & 84.8 \\
\hline $9 \mathrm{H}-1,29-31$ & 75.5 & 2.42 & 1.31 & 0.52 & 3.91 & 60.1 & 79.6 \\
\hline $9 \mathrm{H}-3,29-31$ & 78.5 & 2.53 & 1.34 & 0.55 & 3.88 & 58.8 & 79.5 \\
\hline $9 \mathrm{H}-5,29-31$ & 81.5 & 2.52 & 1.45 & 0.75 & 2.50 & 48.5 & 71.4 \\
\hline $10 \mathrm{H}-1,29-31$ & 85.0 & 2.64 & 1.37 & 0.59 & 3.71 & 56.7 & 78.8 \\
\hline $10 \mathrm{H}-3,29-31$ & 88.0 & 2.30 & 1.34 & 0.60 & 2.99 & 55.1 & 74.9 \\
\hline $10 \mathrm{H}-5,29-31$ & 91.0 & 2.45 & 1.23 & 0.38 & 6.05 & 69.0 & 85.8 \\
\hline $11 \mathrm{H}-1,29-31$ & 94.5 & 2.41 & 1.25 & 0.43 & 5.12 & 66.0 & 83.7 \\
\hline $11 \mathrm{H}-3,29-31$ & 97.5 & 2.69 & 1.58 & 0.91 & 2.04 & 42.1 & 67.2 \\
\hline $11 \mathrm{H}-5,29-31$ & 100.5 & 2.39 & 1.23 & 0.39 & 5.77 & 68.6 & 85.2 \\
\hline $12 \mathrm{H}-1,29-31$ & 104.0 & 2.55 & 1.28 & 0.45 & 5.07 & 64.5 & 83.5 \\
\hline $12 \mathrm{H}-5,29-31$ & 110.0 & 1.82 & 1.19 & 0.42 & 3.59 & 64.8 & 78.2 \\
\hline $13 \mathrm{H}-1,29-31$ & 113.5 & 2.47 & 1.43 & 0.71 & 2.63 & 50.2 & 72.5 \\
\hline $13 \mathrm{H}-3,29-31$ & 116.5 & 2.59 & 1.41 & 0.66 & 3.10 & 53.0 & 75.6 \\
\hline $13 \mathrm{H}-5,29-31$ & 119.5 & 2.43 & 1.22 & 0.37 & 6.33 & 70.0 & 86.4 \\
\hline $13 \mathrm{H}-7,29-31$ & 122.5 & 2.69 & 1.43 & 0.68 & 3.17 & 52.6 & 76.0 \\
\hline $14 \mathrm{H}-1,29-31$ & 123.0 & 2.39 & 1.62 & 1.06 & 1.30 & 34.5 & 56.6 \\
\hline $14 \mathrm{H}-3,29-31$ & 126.0 & 2.64 & 1.43 & 0.68 & 3.05 & 52.2 & 75.3 \\
\hline $14 \mathrm{H}-5,29-31$ & 129.0 & 2.41 & 1.31 & 0.53 & 3.81 & 59.6 & 79.2 \\
\hline $14 \mathrm{H}-7,29-31$ & 132.0 & 2.58 & 1.48 & 0.78 & 2.45 & 47.4 & 71.0 \\
\hline $15 \mathrm{H}-1,29-31$ & 132.5 & 2.36 & 1.31 & 0.53 & 3.68 & 59.3 & 78.7 \\
\hline $15 \mathrm{H}-3,29-31$ & 135.5 & 2.67 & 1.27 & 0.43 & 5.81 & 66.2 & 85.3 \\
\hline $15 \mathrm{H}-5,29-31$ & 138.5 & 2.34 & 1.30 & 0.52 & 3.82 & 60.3 & 79.2 \\
\hline $16 \mathrm{H}-3,29-31$ & 145.0 & 2.35 & 1.26 & 0.45 & 4.68 & 64.6 & 82.4 \\
\hline $16 \mathrm{H}-5,29-31$ & 148.0 & 2.56 & 1.40 & 0.65 & 3.16 & 53.8 & 76.0 \\
\hline $17 \mathrm{H}-1,29-31$ & 151.5 & 2.29 & 1.17 & 0.30 & 7.58 & 74.4 & 88.3 \\
\hline $18 \mathrm{H}-1,29-31$ & 157.5 & 2.52 & 1.32 & 0.53 & 4.11 & 60.2 & 80.4 \\
\hline $18 \mathrm{H}-3,29-31$ & 160.5 & 2.36 & 1.38 & 0.66 & 2.74 & 52.3 & 73.3 \\
\hline $18 \mathrm{H}-5,29-31$ & 167.0 & 2.52 & 1.35 & 0.57 & 3.70 & 57.8 & 78.7 \\
\hline
\end{tabular}


Table T16 (continued). (Continued on next page.)

\begin{tabular}{|c|c|c|c|c|c|c|c|}
\hline \multirow{2}{*}{$\begin{array}{l}\text { Core, section, } \\
\text { interval }(\mathrm{cm})\end{array}$} & \multirow{2}{*}{$\begin{array}{l}\text { Depth } \\
\text { (mbsf) }\end{array}$} & \multicolumn{3}{|c|}{ Density $\left(\mathrm{g} / \mathrm{cm}^{3}\right)$} & \multirow{2}{*}{$\begin{array}{l}\text { Void } \\
\text { ratio }\end{array}$} & \multirow{2}{*}{$\begin{array}{l}\text { Water } \\
\text { content } \\
(\%)\end{array}$} & \multirow{2}{*}{$\begin{array}{c}\text { Porosit } \\
\text { (\%) }\end{array}$} \\
\hline & & Dry grain & Wet bulk & Dry bulk & & & \\
\hline $19 \mathrm{H}-1,29-31$ & 167.0 & 2.57 & 1.35 & 0.57 & 3.81 & 58.0 & 79.2 \\
\hline $19 \mathrm{H}-3,29-31$ & 170.0 & 2.46 & 1.32 & 0.53 & 3.96 & 59.9 & 79.8 \\
\hline $19 \mathrm{H}-5,29-31$ & 173.0 & 2.29 & 1.37 & 0.65 & 2.67 & 52.6 & 72.8 \\
\hline $20 \mathrm{H}-1,29-31$ & 176.5 & 2.55 & 1.29 & 0.47 & 4.79 & 63.3 & 82.7 \\
\hline $20 \mathrm{H}-3,29-31$ & 179.5 & 2.37 & 1.31 & 0.54 & 3.67 & 59.1 & 78.6 \\
\hline $21 \mathrm{H}-1,29-31$ & 181.0 & 2.44 & 1.36 & 0.60 & 3.31 & 56.0 & 76.8 \\
\hline $21 \mathrm{H}-3,29-31$ & 184.0 & 2.40 & 1.30 & 0.51 & 3.96 & 60.5 & 79.8 \\
\hline $22 \mathrm{H}-1,29-31$ & 190.5 & 2.57 & 1.44 & 0.71 & 2.76 & 50.4 & 73.4 \\
\hline $22 \mathrm{H}-3,29-31$ & 193.5 & 2.25 & 1.34 & 0.60 & 2.91 & 54.9 & 74.4 \\
\hline $22 \mathrm{H}-5,29-31$ & 196.5 & 2.53 & 1.44 & 0.72 & 2.64 & 49.8 & 72.6 \\
\hline $23 \mathrm{H}-1,29-31$ & 200.0 & 2.34 & 1.31 & 0.53 & 3.68 & 59.4 & 78.6 \\
\hline $23 \mathrm{H}-3,29-31$ & 203.0 & 3.40 & 1.61 & 0.86 & 3.18 & 46.8 & 76.1 \\
\hline $23 \mathrm{H}-5,29-31$ & 206.0 & 2.13 & 1.27 & 0.50 & 3.47 & 60.3 & 77.6 \\
\hline $24 \mathrm{H}-1,29-31$ & 209.5 & 2.49 & 1.31 & 0.51 & 4.15 & 60.7 & 80.6 \\
\hline $24 \mathrm{H}-3,29-31$ & 212.5 & 2.06 & 1.24 & 0.45 & 3.81 & 63.3 & 79.2 \\
\hline $24 \mathrm{H}-5,29-31$ & 215.5 & 2.24 & 1.26 & 0.47 & 4.07 & 62.8 & 80.3 \\
\hline $25 \mathrm{H}-1,29-31$ & 219.0 & 2.31 & 1.24 & 0.41 & 5.05 & 66.7 & 83.5 \\
\hline $25 \mathrm{H}-3,29-31$ & 222.0 & 2.32 & 1.26 & 0.45 & 4.51 & 64.2 & 81.9 \\
\hline $25 \mathrm{H}-5,29-31$ & 225.0 & 2.40 & 1.28 & 0.47 & 4.44 & 63.0 & 81.6 \\
\hline $26 \mathrm{H}-1,29-31$ & 228.5 & 2.11 & 1.25 & 0.46 & 3.86 & 63.0 & 79.4 \\
\hline $26 \mathrm{H}-3,29-31$ & 231.5 & 2.37 & 1.31 & 0.52 & 3.80 & 59.9 & 79.2 \\
\hline $26 \mathrm{H}-5,29-31$ & 234.5 & 2.34 & 1.32 & 0.56 & 3.40 & 57.7 & 77.3 \\
\hline $27 \mathrm{H}-1,29-31$ & 238.0 & 2.40 & 1.29 & 0.50 & 4.11 & 61.4 & 80.4 \\
\hline $27 \mathrm{H}-3,29-31$ & 241.0 & 2.35 & 1.27 & 0.47 & 4.38 & 63.2 & 81.4 \\
\hline $27 \mathrm{H}-5,29-31$ & 244.0 & 2.44 & 1.32 & 0.54 & 3.83 & 59.3 & 79.3 \\
\hline $28 \mathrm{H}-1,29-31$ & 247.5 & 2.17 & 1.28 & 0.52 & 3.43 & 59.7 & 77.4 \\
\hline $28 \mathrm{H}-3,29-31$ & 250.5 & 2.32 & 1.29 & 0.50 & 3.90 & 61.0 & 79.6 \\
\hline $28 \mathrm{H}-5,29-31$ & 253.5 & 2.31 & 1.32 & 0.55 & 3.40 & 57.9 & 77.3 \\
\hline $29 \mathrm{H}-1,29-31$ & 257.0 & 2.39 & 1.29 & 0.50 & 4.15 & 61.7 & 80.6 \\
\hline $29 \mathrm{H}-3,29-31$ & 260.0 & 2.03 & 1.22 & 0.43 & 3.97 & 64.5 & 79.9 \\
\hline $29 \mathrm{H}-5,29-31$ & 263.0 & 2.37 & 1.28 & 0.48 & 4.25 & 62.4 & 80.9 \\
\hline $30 \mathrm{H}-1,29-31$ & 266.5 & 2.13 & 1.27 & 0.50 & 3.51 & 60.7 & 77.8 \\
\hline $30 \mathrm{H}-3,29-31$ & 269.5 & 2.43 & 1.32 & 0.53 & 3.86 & 59.7 & 79.4 \\
\hline $30 \mathrm{H}-5,29-31$ & 272.5 & 2.28 & 1.29 & 0.51 & 3.75 & 60.5 & 78.9 \\
\hline $31 \mathrm{H}-1,29-31$ & 276.0 & 2.40 & 1.33 & 0.56 & 3.54 & 58.0 & 78.0 \\
\hline $31 \mathrm{H}-3,29-31$ & 279.0 & 2.62 & 1.33 & 0.52 & 4.38 & 60.6 & 81.4 \\
\hline $31 \mathrm{H}-5,29-31$ & 282.0 & 2.40 & 1.33 & 0.56 & 3.54 & 58.0 & 78.0 \\
\hline $32 \mathrm{H}-1,29-31$ & 284.1 & 2.11 & 1.25 & 0.47 & 3.77 & 62.5 & 79.0 \\
\hline $32 \mathrm{H}-3,29-31$ & 286.5 & 2.39 & 1.33 & 0.56 & 3.53 & 58.0 & 77.9 \\
\hline $32 \mathrm{H}-5,29-31$ & 288.6 & 2.34 & 1.29 & 0.50 & 3.97 & 61.1 & 79.9 \\
\hline $33 \mathrm{H}-1,29-31$ & 293.6 & 2.37 & 1.29 & 0.50 & 4.09 & 61.5 & 80.3 \\
\hline $33 \mathrm{H}-3,29-31$ & 296.6 & 2.40 & 1.36 & 0.62 & 3.09 & 54.8 & 75.5 \\
\hline $34 \mathrm{H}-1,29-31$ & 301.5 & 2.38 & 1.30 & 0.52 & 3.88 & 60.3 & 79.5 \\
\hline $34 \mathrm{H}-3,29-31$ & 304.5 & 2.14 & 1.29 & 0.54 & 3.18 & 58.2 & 76.1 \\
\hline $35 \mathrm{H}-1,29-31$ & 307.6 & 2.47 & 1.41 & 0.69 & 2.76 & 51.4 & 73.4 \\
\hline $35 \mathrm{H}-3,29-31$ & 310.6 & 2.46 & 1.44 & 0.73 & 2.50 & 49.1 & 71.4 \\
\hline $33 \mathrm{H}-5,29-31$ & 313.6 & 2.55 & 1.40 & 0.66 & 3.06 & 53.0 & 75.4 \\
\hline $36 \mathrm{H}-1,29-31$ & 317.1 & 2.68 & 1.47 & 0.74 & 2.77 & 49.5 & 73.5 \\
\hline $36 \mathrm{H}-3,29-31$ & 320.1 & 2.39 & 1.43 & 0.73 & 2.40 & 48.9 & 70.6 \\
\hline $36 \mathrm{H}-5,29-31$ & 323.1 & 2.47 & 1.42 & 0.71 & 2.64 & 50.3 & 72.6 \\
\hline $37 \mathrm{H}-1,29-31$ & 326.6 & 2.38 & 1.32 & 0.54 & 3.62 & 58.7 & 78.4 \\
\hline $37 \mathrm{H}-3,29-31$ & 329.6 & 2.51 & 1.37 & 0.62 & 3.29 & 55.2 & 76.7 \\
\hline $37 \mathrm{H}-5,29-31$ & 332.6 & 2.42 & 1.34 & 0.57 & 3.47 & 57.3 & 77.6 \\
\hline $38 \mathrm{H}-1,29-31$ & 336.1 & 2.43 & 1.32 & 0.53 & 3.85 & 59.6 & 79.4 \\
\hline $38 \mathrm{H}-3,29-31$ & 339.1 & 2.15 & 1.28 & 0.51 & 3.47 & 60.2 & 77.6 \\
\hline $38 \mathrm{H}-5,29-31$ & 342.1 & 2.49 & 1.41 & 0.68 & 2.86 & 52.0 & 74.1 \\
\hline $39 \mathrm{H}-1,29-31$ & 345.6 & 2.44 & 1.38 & 0.64 & 2.98 & 53.5 & 74.9 \\
\hline $39 \mathrm{H}-3,29-31$ & 348.6 & 2.40 & 1.30 & 0.51 & 3.96 & 60.6 & 79.9 \\
\hline $39 \mathrm{H}-5,29-31$ & 351.6 & 2.12 & 1.25 & 0.47 & 3.76 & 62.3 & 79.0 \\
\hline $40 \mathrm{H}-1,29-31$ & 355.1 & 2.37 & 1.25 & 0.42 & 5.04 & 66.0 & 83.4 \\
\hline $40 \mathrm{H}-3,29-31$ & 357.6 & 2.01 & 1.23 & 0.45 & 3.73 & 63.4 & 78.9 \\
\hline $41 \mathrm{H}-1,29-31$ & 358.6 & 2.43 & 1.32 & 0.54 & 3.76 & 59.1 & 79.0 \\
\hline $41 \mathrm{H}-3,29-31$ & 361.6 & 2.27 & 1.35 & 0.61 & 2.87 & 54.4 & 74.2 \\
\hline $41 \mathrm{H}-5,29-31$ & 364.6 & 2.42 & 1.38 & 0.64 & 2.97 & 53.6 & 74.8 \\
\hline $42 \mathrm{H}-1,29-31$ & 368.1 & 2.15 & 1.20 & 0.37 & 5.29 & 69.1 & 84.1 \\
\hline $42 \mathrm{H}-3,29-31$ & 371.1 & 2.18 & 1.30 & 0.55 & 3.12 & 57.4 & 75.8 \\
\hline $42 \mathrm{H}-5,29-31$ & 374.1 & 2.47 & 1.38 & 0.63 & 3.13 & 54.4 & 75.8 \\
\hline $43 \mathrm{H}-2,29-31$ & 376.5 & 2.51 & 1.39 & 0.64 & 3.10 & 53.8 & 75.6 \\
\hline
\end{tabular}


Table T16 (continued).

\begin{tabular}{|c|c|c|c|c|c|c|c|}
\hline \multirow{2}{*}{$\begin{array}{l}\text { Core, section, } \\
\text { interval }(\mathrm{cm})\end{array}$} & \multirow{2}{*}{$\begin{array}{l}\text { Depth } \\
\text { (mbsf) }\end{array}$} & \multicolumn{3}{|c|}{ Density $\left(\mathrm{g} / \mathrm{cm}^{3}\right)$} & \multirow{2}{*}{$\begin{array}{l}\text { Void } \\
\text { ratio }\end{array}$} & \multirow{2}{*}{$\begin{array}{l}\text { Water } \\
\text { content } \\
(\%)\end{array}$} & \multirow{2}{*}{$\begin{array}{c}\text { Porosity } \\
\text { (\%) }\end{array}$} \\
\hline & & Dry grain & Wet bulk & Dry bulk & & & \\
\hline $43 \mathrm{H}-4,29-31$ & 379.5 & 2.07 & 1.28 & 0.53 & 3.09 & 58.4 & 75.6 \\
\hline $43 \mathrm{H}-6,29-31$ & 381.7 & 2.32 & 1.38 & 0.66 & 2.66 & 52.1 & 72.7 \\
\hline $44 \mathrm{H}-1,29-31$ & 385.6 & 2.48 & 1.45 & 0.75 & 2.45 & 48.4 & 71.0 \\
\hline $44 \mathrm{H}-3,29-31$ & 388.6 & 2.40 & 1.37 & 0.63 & 3.02 & 54.2 & 75.1 \\
\hline $45 \mathrm{H}-1,29-31$ & 395.1 & 2.45 & 1.40 & 0.67 & 2.80 & 51.9 & 73.7 \\
\hline $45 \mathrm{H}-3,29-31$ & 398.1 & 2.27 & 1.37 & 0.65 & 2.66 & 52.6 & 72.7 \\
\hline $45 \mathrm{H}-5,29-31$ & 401.1 & 2.49 & 1.49 & 0.81 & 2.19 & 45.6 & 68.7 \\
\hline $46 \mathrm{H}-1,29-31$ & 404.1 & 2.31 & 1.32 & 0.55 & 3.41 & 58.1 & 77.3 \\
\hline $46 \mathrm{H}-3,29-31$ & 407.1 & 2.42 & 1.36 & 0.61 & 3.17 & 55.2 & 76.0 \\
\hline $46 \mathrm{H}-5,29-31$ & 410.1 & 2.35 & 1.38 & 0.66 & 2.70 & 52.1 & 73.0 \\
\hline $48 \mathrm{H}-1,29-31$ & 414.9 & 2.34 & 1.39 & 0.68 & 2.60 & 51.2 & 72.2 \\
\hline $48 \mathrm{H}-3,29-31$ & 417.9 & 2.10 & 1.30 & 0.57 & 2.83 & 55.9 & 73.9 \\
\hline $48 \mathrm{H}-5,29-31$ & 420.9 & 2.23 & 1.39 & 0.69 & 2.33 & 49.9 & 70.0 \\
\hline $50 \mathrm{H}-3,29-31$ & 426.6 & 2.22 & 1.30 & 0.54 & 3.30 & 58.2 & 76.7 \\
\hline $50 \mathrm{H}-5,29-31$ & 429.6 & 2.28 & 1.33 & 0.58 & 3.14 & 56.5 & 75.9 \\
\hline $51 \mathrm{H}-1,29-31$ & 431.5 & 2.33 & 1.32 & 0.56 & 3.39 & 57.7 & 77.2 \\
\hline $51 \mathrm{H}-3,29-31$ & 434.5 & 2.30 & 1.37 & 0.66 & 2.64 & 52.1 & 72.5 \\
\hline $51 \mathrm{H}-5,29-31$ & 437.5 & 2.04 & 1.31 & 0.60 & 2.54 & 54.2 & 71.7 \\
\hline $52 \mathrm{H}-1,29-31$ & 439.3 & 2.32 & 1.35 & 0.62 & 2.94 & 54.5 & 74.6 \\
\hline $52 \mathrm{H}-3,29-31$ & 442.3 & 2.19 & 1.30 & 0.54 & 3.25 & 58.2 & 76.5 \\
\hline $52 \mathrm{H}-5,29-31$ & 445.3 & 2.24 & 1.31 & 0.55 & 3.31 & 58.1 & 76.8 \\
\hline $53 \mathrm{H}-1,29-31$ & 448.8 & 2.30 & 1.30 & 0.52 & 3.69 & 59.9 & 78.7 \\
\hline $53 \mathrm{H}-3,29-31$ & 451.8 & 2.33 & 1.31 & 0.54 & 3.60 & 59.1 & 78.3 \\
\hline $53 \mathrm{H}-5,29-31$ & 454.8 & 2.08 & 1.30 & 0.57 & 2.85 & 56.4 & 74.0 \\
\hline $57 X-1,29-31$ & 458.7 & 2.24 & 1.34 & 0.62 & 2.80 & 54.1 & 73.7 \\
\hline $57 X-3,29-31$ & 461.7 & 2.22 & 1.37 & 0.67 & 2.47 & 51.3 & 71.2 \\
\hline $59 X-2,29-31$ & 478.8 & 2.22 & 1.30 & 0.55 & 3.28 & 58.1 & 76.6 \\
\hline $59 X-4,29-31$ & 481.8 & 2.30 & 1.33 & 0.58 & 3.18 & 56.5 & 76.1 \\
\hline $60 \times-2,29-31$ & 488.5 & 2.31 & 1.28 & 0.48 & 4.16 & 62.5 & 80.6 \\
\hline $60 X-4,29-31$ & 491.5 & 2.15 & 1.28 & 0.52 & 3.38 & 59.5 & 77.2 \\
\hline $60 X-6,29-31$ & 494.5 & 2.27 & 1.31 & 0.54 & 3.41 & 58.5 & 77.3 \\
\hline $61 X-2,29-31$ & 498.0 & 2.16 & 1.29 & 0.53 & 3.27 & 58.7 & 76.6 \\
\hline $61 X-4,29-31$ & 501.0 & 2.29 & 1.34 & 0.60 & 3.04 & 55.6 & 75.3 \\
\hline $61 X-6,29-31$ & 503.8 & 2.13 & 1.36 & 0.67 & 2.29 & 50.5 & 69.6 \\
\hline $62 X-2,29-31$ & 507.7 & 2.25 & 1.34 & 0.61 & 2.83 & 54.3 & 73.9 \\
\hline $62 X-4,29-31$ & 510.7 & 2.17 & 1.32 & 0.59 & 2.87 & 55.6 & 74.2 \\
\hline $62 X-6,29-31$ & 513.7 & 2.18 & 1.33 & 0.60 & 2.79 & 54.7 & 73.6 \\
\hline $63 X-2,29-31$ & 517.4 & 1.84 & 1.19 & 0.41 & 3.71 & 65.3 & 78.8 \\
\hline $63 X-4,29-31$ & 520.4 & 2.37 & 1.52 & 0.89 & 1.76 & 41.6 & 63.7 \\
\hline $63 X-6,29-31$ & 523.4 & 2.22 & 1.46 & 0.83 & 1.75 & 43.1 & 63.6 \\
\hline $64 X-2,29-31$ & 527.0 & 2.20 & 1.29 & 0.52 & 3.45 & 59.5 & 77.5 \\
\hline $64 X-4,29-31$ & 530.0 & 2.14 & 1.29 & 0.55 & 3.10 & 57.7 & 75.6 \\
\hline $64 X-6,29-31$ & 533.0 & 2.16 & 1.31 & 0.57 & 2.99 & 56.6 & 74.9 \\
\hline $65 X-1,29-31$ & 536.6 & 2.11 & 1.26 & 0.49 & 3.60 & 61.4 & 78.2 \\
\hline $65 X-5,29-31$ & 542.4 & 2.08 & 1.31 & 0.60 & 2.63 & 54.6 & 72.5 \\
\hline $66 X-1,29-31$ & 544.7 & 2.14 & 1.31 & 0.57 & 2.97 & 56.7 & 74.8 \\
\hline $66 X-3,29-31$ & 547.7 & 2.17 & 1.35 & 0.64 & 2.55 & 52.7 & 71.8 \\
\hline $67 X-1,29-31$ & 554.3 & 2.18 & 1.26 & 0.48 & 3.82 & 62.0 & 79.3 \\
\hline $67 X-3,29-31$ & 557.3 & 2.15 & 1.24 & 0.45 & 4.09 & 63.8 & 80.3 \\
\hline $67 X-5,29-31$ & 560.3 & 2.24 & 1.26 & 0.46 & 4.18 & 63.3 & 80.7 \\
\hline $68 X-1,29-31$ & 564.0 & 2.22 & 1.38 & 0.69 & 2.31 & 49.9 & 69.8 \\
\hline $68 X-3,29-31$ & 567.0 & 2.31 & 1.36 & 0.63 & 2.81 & 53.5 & 73.7 \\
\hline $68 X-5,29-31$ & 570.0 & 2.23 & 1.35 & 0.63 & 2.72 & 53.6 & 73.1 \\
\hline $70 X-1,29-31$ & 583.2 & 2.13 & 1.30 & 0.56 & 3.01 & 57.1 & 75.1 \\
\hline $70 X-3,29-31$ & 586.2 & 1.93 & 1.24 & 0.50 & 3.04 & 59.8 & 75.3 \\
\hline $70 \times-5,29-31$ & 589.2 & 2.35 & 1.38 & 0.65 & 2.80 & 52.9 & 73.7 \\
\hline $71 X-1,29-31$ & 592.8 & 2.01 & 1.29 & 0.56 & 2.73 & 56.3 & 73.2 \\
\hline $71 X-3,29-31$ & 595.8 & 2.12 & 1.28 & 0.52 & 3.32 & 59.4 & 76.8 \\
\hline $71 X-5,29-31$ & 598.8 & 2.10 & 1.28 & 0.53 & 3.18 & 58.8 & 76.1 \\
\hline
\end{tabular}


Table T17. Affine table indicating the amount that each core in each hole needs to be offset in order to construct a continuous record, Site U1341. (Continued on next two pages.)

\begin{tabular}{|c|c|c|c|c|c|c|c|}
\hline \multirow[b]{2}{*}{ Core } & \multicolumn{2}{|c|}{ Depth (mbsf) } & \multirow{2}{*}{$\begin{array}{l}\text { Offset } \\
(\mathrm{m})\end{array}$} & \multicolumn{2}{|c|}{ Depth CCSF-A (m) } & \multirow{2}{*}{$\begin{array}{l}\text { Recovered } \\
\text { (m) }\end{array}$} & \multirow{2}{*}{$\begin{array}{c}\text { Recovery } \\
(\%)\end{array}$} \\
\hline & Top & Bottom & & Top & Bottom & & \\
\hline \multicolumn{8}{|c|}{ 323-U1341A- } \\
\hline $1 \mathrm{H}$ & 0.00 & 3.04 & 0.00 & 0.00 & 3.04 & 3.04 & 101 \\
\hline $2 \mathrm{H}$ & 3.00 & 12.64 & 0.35 & 3.35 & 12.99 & 9.49 & 100 \\
\hline $3 \mathrm{H}$ & 12.50 & 22.43 & 0.46 & 12.96 & 22.89 & 9.75 & 103 \\
\hline $4 \mathrm{H}$ & 22.00 & 31.77 & 0.83 & 22.83 & 32.60 & 9.49 & 100 \\
\hline $5 \mathrm{H}$ & 31.50 & 41.32 & 1.91 & 33.41 & 43.23 & 9.51 & 100 \\
\hline $6 \mathrm{H}$ & 41.00 & 50.95 & 3.42 & 44.42 & 54.37 & 9.75 & 103 \\
\hline $7 \mathrm{H}$ & 50.50 & 60.51 & 3.66 & 54.16 & 64.17 & 9.73 & 102 \\
\hline $8 \mathrm{H}$ & 60.00 & 69.41 & 4.89 & 64.89 & 74.30 & 9.09 & 96 \\
\hline $9 \mathrm{H}$ & 69.50 & 79.66 & 4.84 & 74.34 & 84.50 & 9.89 & 104 \\
\hline $10 \mathrm{H}$ & 79.00 & 89.12 & 5.05 & 84.05 & 94.17 & 10.12 & 107 \\
\hline $11 \mathrm{H}$ & 88.50 & 98.51 & 5.15 & 93.65 & 103.66 & 10.01 & 105 \\
\hline $12 \mathrm{H}$ & 98.00 & 108.16 & 5.36 & 103.36 & 113.52 & 10.16 & 107 \\
\hline $13 \mathrm{H}$ & 107.50 & 117.70 & 4.97 & 112.47 & 122.67 & 10.20 & 107 \\
\hline $14 \mathrm{H}$ & 117.00 & 127.10 & 3.53 & 120.53 & 130.63 & 10.10 & 106 \\
\hline $15 \mathrm{H}$ & 126.50 & 136.26 & 4.58 & 131.08 & 140.84 & 9.76 & 103 \\
\hline $16 \mathrm{H}$ & 136.00 & 146.07 & 10.12 & 146.12 & 156.19 & 10.07 & 106 \\
\hline $17 \mathrm{H}$ & 145.50 & 155.63 & 9.92 & 155.42 & 165.55 & 10.13 & 107 \\
\hline $18 \mathrm{H}$ & 155.00 & 165.02 & 10.89 & 165.89 & 175.91 & 10.02 & 105 \\
\hline $19 \mathrm{H}$ & 164.50 & 174.49 & 10.66 & 175.16 & 185.15 & 9.99 & 105 \\
\hline $20 \mathrm{H}$ & 174.00 & 183.92 & 12.31 & 186.31 & 196.23 & 9.92 & 104 \\
\hline $21 \mathrm{H}$ & 183.50 & 193.35 & 13.81 & 197.31 & 207.16 & 9.85 & 104 \\
\hline $22 \mathrm{H}$ & 193.00 & 203.13 & 17.18 & 210.18 & 220.31 & 10.13 & 107 \\
\hline $23 \mathrm{H}$ & 202.50 & 212.63 & 13.53 & 216.03 & 226.16 & 10.13 & 107 \\
\hline $24 \mathrm{H}$ & 212.00 & 221.34 & 15.50 & 227.50 & 236.84 & 9.44 & 99 \\
\hline $25 \mathrm{H}$ & 221.50 & 231.43 & 13.78 & 235.28 & 245.21 & 9.93 & 105 \\
\hline $26 \mathrm{H}$ & 231.00 & 233.21 & 16.00 & 247.00 & 249.21 & 2.21 & 100 \\
\hline $27 \mathrm{H}$ & 233.20 & 241.50 & 16.15 & 249.35 & 257.65 & 8.30 & 87 \\
\hline $28 \mathrm{H}$ & 242.70 & 252.54 & 16.11 & 258.81 & 268.65 & 9.84 & 104 \\
\hline $29 \mathrm{H}$ & 252.20 & 262.24 & 16.51 & 268.71 & 278.75 & 10.04 & 106 \\
\hline $30 \mathrm{H}$ & 261.70 & 271.82 & 17.37 & 279.07 & 289.19 & 9.84 & 104 \\
\hline $31 \mathrm{H}$ & 271.20 & 281.30 & 17.55 & 288.75 & 298.85 & 9.83 & 103 \\
\hline $32 \mathrm{H}$ & 280.70 & 290.61 & 19.78 & 300.48 & 310.39 & 9.62 & 101 \\
\hline $33 \mathrm{H}$ & 290.20 & 300.19 & 17.20 & 307.40 & 317.39 & 9.71 & 102 \\
\hline $34 \mathrm{H}$ & 299.70 & 309.52 & 17.10 & 316.80 & 326.62 & 9.82 & 103 \\
\hline $35 \mathrm{H}$ & 309.20 & 319.02 & 17.23 & 326.43 & 336.25 & 9.61 & 101 \\
\hline $36 \mathrm{H}$ & 318.70 & 328.19 & 18.29 & 336.99 & 346.48 & 9.49 & 100 \\
\hline $37 \mathrm{H}$ & 328.20 & 332.81 & 18.62 & 346.82 & 351.43 & 4.61 & 102 \\
\hline $38 \mathrm{H}$ & 332.70 & 342.26 & 18.66 & 351.36 & 360.92 & 9.56 & 101 \\
\hline $39 \mathrm{H}$ & 342.20 & 352.03 & 19.16 & 361.36 & 371.19 & 9.83 & 103 \\
\hline $40 \mathrm{H}$ & 351.70 & 356.78 & 18.96 & 370.66 & 375.74 & 5.08 & 113 \\
\hline $41 \mathrm{H}$ & 356.20 & 359.12 & 19.50 & 375.70 & 378.62 & 2.92 & 97 \\
\hline \multicolumn{8}{|c|}{ 323-U1341B- } \\
\hline $1 \mathrm{H}$ & 0.00 & 8.72 & -0.06 & -0.06 & 8.66 & 8.70 & 100 \\
\hline $2 \mathrm{H}$ & 8.70 & 18.58 & -0.18 & 8.52 & 18.40 & 9.60 & 101 \\
\hline $3 \mathrm{H}$ & 18.20 & 28.18 & 0.45 & 18.65 & 28.63 & 10.00 & 105 \\
\hline $4 \mathrm{H}$ & 27.70 & 37.70 & 1.25 & 28.95 & 38.95 & 10.00 & 105 \\
\hline $5 \mathrm{H}$ & 37.20 & 47.18 & 2.43 & 39.63 & 49.61 & 10.00 & 105 \\
\hline $6 \mathrm{H}$ & 46.70 & 57.12 & 2.71 & 49.41 & 59.83 & 10.00 & 105 \\
\hline $7 \mathrm{H}$ & 56.20 & 66.18 & 2.79 & 58.99 & 68.97 & 10.00 & 105 \\
\hline $8 \mathrm{H}$ & 65.70 & 75.75 & 4.25 & 69.95 & 80.00 & 10.10 & 106 \\
\hline $9 \mathrm{H}$ & 75.20 & 85.24 & 5.26 & 80.46 & 90.50 & 10.00 & 105 \\
\hline $10 \mathrm{H}$ & 84.70 & 94.20 & 5.72 & 90.42 & 99.92 & 9.50 & 100 \\
\hline $11 \mathrm{H}$ & 94.20 & 104.25 & 5.98 & 100.18 & 110.23 & 9.80 & 103 \\
\hline $12 \mathrm{H}$ & 103.70 & 113.59 & 6.39 & 110.09 & 119.98 & 9.60 & 101 \\
\hline $13 \mathrm{H}$ & 113.20 & 123.24 & 8.39 & 121.59 & 131.63 & 9.70 & 102 \\
\hline $14 \mathrm{H}$ & 122.70 & 132.84 & 8.74 & 131.44 & 141.58 & 9.90 & 104 \\
\hline $15 \mathrm{H}$ & 132.20 & 142.36 & 8.77 & 140.97 & 151.13 & 9.80 & 103 \\
\hline $16 \mathrm{H}$ & 141.70 & 151.68 & 9.74 & 151.44 & 161.42 & 9.60 & 101 \\
\hline $17 \mathrm{H}$ & 151.20 & 158.19 & 8.57 & 159.77 & 166.76 & 6.80 & 113 \\
\hline $18 \mathrm{H}$ & 157.20 & 166.81 & 10.43 & 167.63 & 177.24 & 9.20 & 97 \\
\hline $19 \mathrm{H}$ & 166.70 & 176.65 & 10.34 & 177.04 & 186.99 & 9.90 & 104 \\
\hline $20 \mathrm{H}$ & 176.20 & 180.17 & 11.18 & 187.38 & 191.35 & 3.70 & 82 \\
\hline $21 \mathrm{H}$ & 180.70 & 190.72 & 11.27 & 191.97 & 201.99 & 10.00 & 105 \\
\hline $22 \mathrm{H}$ & 190.20 & 199.97 & 12.47 & 202.67 & 212.44 & 9.80 & 103 \\
\hline $23 \mathrm{H}$ & 199.70 & 209.78 & 12.09 & 211.79 & 221.87 & 10.10 & 106 \\
\hline $24 \mathrm{H}$ & 209.20 & 218.93 & 13.26 & 222.46 & 232.19 & 9.70 & 102 \\
\hline
\end{tabular}


Table T17 (continued). (Continued on next page.)

\begin{tabular}{|c|c|c|c|c|c|c|c|}
\hline \multirow[b]{2}{*}{ Core } & \multicolumn{2}{|c|}{ Depth (mbsf) } & \multirow{2}{*}{$\begin{array}{l}\text { Offset } \\
(\mathrm{m})\end{array}$} & \multicolumn{2}{|c|}{ Depth CCSF-A (m) } & \multirow{2}{*}{$\begin{array}{l}\text { Recovered } \\
(\mathrm{m})\end{array}$} & \multirow{2}{*}{$\begin{array}{c}\text { Recovery } \\
\text { (\%) }\end{array}$} \\
\hline & Top & Bottom & & Top & Bottom & & \\
\hline $25 \mathrm{H}$ & 218.70 & 228.52 & 14.94 & 233.64 & 243.46 & 9.80 & 103 \\
\hline $26 \mathrm{H}$ & 228.20 & 238.21 & 14.72 & 242.92 & 252.93 & 10.00 & 105 \\
\hline $27 \mathrm{H}$ & 237.70 & 247.60 & 15.44 & 253.14 & 263.04 & 9.90 & 104 \\
\hline $28 \mathrm{H}$ & 247.20 & 257.19 & 15.52 & 262.72 & 272.71 & 10.00 & 105 \\
\hline $29 \mathrm{H}$ & 256.70 & 266.02 & 16.08 & 272.78 & 282.10 & 9.30 & 98 \\
\hline $30 \mathrm{H}$ & 266.20 & 276.19 & 17.07 & 283.27 & 293.26 & 10.00 & 105 \\
\hline $31 \mathrm{H}$ & 275.70 & 283.81 & 17.94 & 293.64 & 301.75 & 8.10 & 100 \\
\hline $32 \mathrm{H}$ & 283.80 & 291.66 & 18.05 & 301.85 & 309.71 & 7.90 & 83 \\
\hline $33 \mathrm{H}$ & 293.30 & 301.23 & 17.33 & 310.63 & 318.56 & 7.70 & 97 \\
\hline $34 \mathrm{H}$ & 301.20 & 307.32 & 17.83 & 319.03 & 325.15 & 6.10 & 100 \\
\hline $35 \mathrm{H}$ & 307.30 & 316.75 & 18.40 & 325.70 & 335.15 & 9.40 & 99 \\
\hline $36 \mathrm{H}$ & 316.80 & 325.93 & 17.90 & 334.70 & 343.83 & 9.10 & 96 \\
\hline $37 \mathrm{H}$ & 326.30 & 335.28 & 18.73 & 345.03 & 354.01 & 9.00 & 95 \\
\hline $38 \mathrm{H}$ & 335.80 & 345.78 & 19.09 & 354.89 & 364.87 & 9.70 & 102 \\
\hline $39 \mathrm{H}$ & 345.30 & 355.09 & 19.62 & 364.92 & 374.71 & 9.80 & 103 \\
\hline $40 \mathrm{H}$ & 354.80 & 358.11 & 19.95 & 374.75 & 378.06 & 3.10 & 89 \\
\hline $41 \mathrm{H}$ & 358.30 & 366.24 & 19.95 & 378.25 & 386.19 & 7.70 & 81 \\
\hline $42 \mathrm{H}$ & 367.80 & 375.68 & 19.95 & 387.75 & 395.63 & 7.90 & 99 \\
\hline $43 \mathrm{H}$ & 375.80 & 385.48 & 19.95 & 395.75 & 405.43 & 9.70 & 102 \\
\hline $44 \mathrm{H}$ & 385.30 & 395.12 & 19.95 & 405.25 & 415.07 & 9.80 & 103 \\
\hline $45 \mathrm{H}$ & 394.80 & 403.59 & 19.95 & 414.75 & 423.54 & 8.80 & 98 \\
\hline $46 \mathrm{H}$ & 403.80 & 413.70 & 19.95 & 423.75 & 433.65 & 9.90 & 104 \\
\hline $47 \mathrm{H}$ & 413.30 & 414.53 & 19.95 & 433.25 & 434.48 & 1.20 & 92 \\
\hline $48 \mathrm{H}$ & 414.60 & 422.84 & 19.95 & 434.55 & 442.79 & 8.20 & 100 \\
\hline $49 \mathrm{H}$ & 422.80 & 423.29 & 19.95 & 442.75 & 443.24 & 0.50 & 100 \\
\hline $50 \mathrm{H}$ & 423.30 & 431.18 & 19.95 & 443.25 & 451.13 & 7.90 & 100 \\
\hline $51 \mathrm{H}$ & 431.20 & 439.04 & 19.95 & 451.15 & 458.99 & 7.80 & 100 \\
\hline $52 \mathrm{H}$ & 439.00 & 448.86 & 19.95 & 458.95 & 468.81 & 9.90 & 104 \\
\hline $53 \mathrm{H}$ & 448.50 & 457.80 & 19.95 & 468.45 & 477.75 & 9.30 & 100 \\
\hline $54 \mathrm{H}$ & 457.80 & 458.33 & 19.95 & 477.75 & 478.28 & 0.50 & 100 \\
\hline $55 \mathrm{H}$ & 458.30 & 458.36 & 19.95 & 478.25 & 478.31 & 0.10 & 100 \\
\hline $56 \mathrm{H}$ & 458.40 & 458.42 & 19.95 & 478.35 & 478.37 & 0.00 & 0 \\
\hline $57 X$ & 458.40 & 467.33 & 19.95 & 478.35 & 487.28 & 8.90 & 96 \\
\hline $58 \mathrm{X}$ & 467.70 & 476.75 & 19.95 & 487.65 & 496.70 & 9.05 & 97 \\
\hline $59 x$ & 477.00 & 486.77 & 19.95 & 496.95 & 506.72 & 9.49 & 98 \\
\hline $60 x$ & 486.70 & 496.46 & 19.95 & 506.65 & 516.41 & 9.76 & 103 \\
\hline $61 x$ & 496.20 & 504.34 & 19.95 & 516.15 & 524.29 & 7.84 & 81 \\
\hline $62 X$ & 505.90 & 515.72 & 19.95 & 525.85 & 535.67 & 9.49 & 98 \\
\hline $63 x$ & 515.60 & 525.46 & 19.95 & 535.55 & 545.41 & 9.49 & 99 \\
\hline $64 X$ & 525.20 & 534.86 & 19.95 & 545.15 & 554.81 & 9.35 & 97 \\
\hline $65 x$ & 534.80 & 543.02 & 19.95 & 554.75 & 562.97 & 9.33 & 97 \\
\hline $66 x$ & 544.40 & 549.36 & 19.95 & 564.35 & 569.31 & 4.50 & 47 \\
\hline $67 X$ & 554.00 & 563.68 & 19.95 & 573.95 & 583.63 & 9.45 & 97 \\
\hline $68 x$ & 563.70 & 573.48 & 19.95 & 583.65 & 593.43 & 9.78 & 102 \\
\hline $69 x$ & 573.30 & 573.54 & 19.95 & 593.25 & 593.49 & 0.24 & 2 \\
\hline $70 x$ & 582.90 & 592.56 & 19.95 & 602.85 & 612.51 & 9.66 & 101 \\
\hline $71 x$ & 592.50 & 601.87 & 19.95 & 612.45 & 621.82 & 9.37 & 125 \\
\hline \multicolumn{8}{|c|}{ 323-U1341C- } \\
\hline $1 \mathrm{H}$ & 0.00 & 5.54 & 0.06 & 0.06 & 5.60 & 5.54 & 101 \\
\hline $2 \mathrm{H}$ & 5.50 & 15.44 & 0.37 & 5.87 & 15.81 & 9.94 & 105 \\
\hline $3 \mathrm{H}$ & 15.00 & 24.92 & 1.03 & 16.03 & 25.95 & 9.92 & 104 \\
\hline $4 \mathrm{H}$ & 24.50 & 34.51 & 1.63 & 26.13 & 36.14 & 10.01 & 105 \\
\hline $5 \mathrm{H}$ & 34.00 & 41.79 & 1.03 & 35.03 & 42.82 & 7.79 & 82 \\
\hline $6 \mathrm{H}$ & 43.50 & 53.62 & 3.91 & 47.41 & 57.53 & 9.91 & 104 \\
\hline $7 \mathrm{H}$ & 53.00 & 62.24 & 4.41 & 57.41 & 66.65 & 9.24 & 116 \\
\hline $8 \mathrm{H}$ & 61.00 & 71.06 & 5.03 & 66.03 & 76.09 & 10.06 & 106 \\
\hline $9 \mathrm{H}$ & 70.50 & 80.62 & 6.31 & 76.81 & 86.93 & 10.12 & 107 \\
\hline $10 \mathrm{H}$ & 80.00 & 90.05 & 7.35 & 87.35 & 97.40 & 10.05 & 106 \\
\hline $11 \mathrm{H}$ & 89.50 & 97.03 & 6.59 & 96.09 & 103.62 & 7.53 & 126 \\
\hline $12 \mathrm{H}$ & 95.50 & 105.74 & 8.22 & 103.72 & 113.96 & 10.24 & 108 \\
\hline $13 \mathrm{H}$ & 105.00 & 115.15 & 8.49 & 113.49 & 123.64 & 10.15 & 107 \\
\hline $14 \mathrm{H}$ & 114.50 & 124.66 & 3.84 & 118.34 & 128.50 & 9.84 & 104 \\
\hline $15 \mathrm{H}$ & 124.00 & 134.06 & 4.15 & 128.15 & 138.21 & 9.85 & 104 \\
\hline $16 \mathrm{H}$ & 133.50 & 139.65 & 8.61 & 142.11 & 148.26 & 6.15 & 154 \\
\hline $17 \mathrm{H}$ & 137.50 & 147.18 & 10.21 & 147.71 & 157.39 & 9.49 & 100 \\
\hline $18 \mathrm{H}$ & 147.00 & 157.10 & 8.82 & 155.82 & 165.92 & 9.83 & 103 \\
\hline $19 \mathrm{H}$ & 156.50 & 166.60 & 10.67 & 167.17 & 177.27 & 9.90 & 104 \\
\hline $20 \mathrm{H}$ & 166.00 & 176.08 & 11.96 & 177.96 & 188.04 & 9.81 & 103 \\
\hline
\end{tabular}


Table T17 (continued).

\begin{tabular}{|c|c|c|c|c|c|c|c|}
\hline \multirow[b]{2}{*}{ Core } & \multicolumn{2}{|c|}{ Depth (mbsf) } & \multirow{2}{*}{$\begin{array}{l}\text { Offset } \\
(\mathrm{m})\end{array}$} & \multicolumn{2}{|c|}{ Depth CCSF-A (m) } & \multirow{2}{*}{$\begin{array}{c}\text { Recovered } \\
(\mathrm{m})\end{array}$} & \multirow{2}{*}{$\begin{array}{l}\text { Recovery } \\
(\%)\end{array}$} \\
\hline & Top & Bottom & & Top & Bottom & & \\
\hline $21 \mathrm{H}$ & 175.50 & 185.55 & 12.13 & 187.63 & 197.68 & 10.05 & 106 \\
\hline $22 \mathrm{D}$ & 185.00 & 185.00 & 12.47 & 197.47 & 197.47 & 0.00 & 0 \\
\hline $23 \mathrm{H}$ & 187.00 & 197.06 & 13.37 & 200.37 & 210.43 & 10.06 & 106 \\
\hline $24 \mathrm{H}$ & 196.50 & 201.68 & 12.13 & 208.63 & 213.81 & 5.18 & 104 \\
\hline $25 \mathrm{H}$ & 201.50 & 211.27 & 14.33 & 215.83 & 225.60 & 9.77 & 103 \\
\hline $26 \mathrm{H}$ & 211.00 & 220.92 & 15.21 & 226.21 & 236.13 & 9.92 & 104 \\
\hline \multirow[t]{2}{*}{$27 \mathrm{H}$} & 220.50 & 230.54 & 16.33 & 236.83 & 246.87 & 10.04 & 106 \\
\hline & & & & & Total: & 1199.7 & 101 \\
\hline
\end{tabular}

Table T18. Splice table indicating tie points between holes, Site U1341. Sampling along the splice should be used to construct a continuous record. (Continued on next page.)

\begin{tabular}{|c|c|c|c|c|c|c|}
\hline \multirow[b]{2}{*}{$\begin{array}{l}\text { Hole, core, section, } \\
\text { interval }(\mathrm{cm})\end{array}$} & \multicolumn{2}{|c|}{ Depth } & & \multirow[b]{2}{*}{$\begin{array}{l}\text { Hole, core, section, } \\
\text { interval }(\mathrm{cm})\end{array}$} & \multicolumn{2}{|c|}{ Depth } \\
\hline & mbsf & $\begin{array}{l}\text { CCSF-D } \\
(\mathrm{m})\end{array}$ & & & mbsf & $\begin{array}{l}\text { CCSF-D } \\
(\mathrm{m})\end{array}$ \\
\hline $323-$ & & & & $323-$ & & \\
\hline U1341A-1H-2, 92.6 & 2.43 & 2.43 & Tie to & U1341B-1H-2, 99.1 & 2.49 & 2.43 \\
\hline U1341B-1H-5, 108.3 & 7.08 & 7.02 & Tie to & U1341C-2H-1, 115.2 & 6.65 & 7.02 \\
\hline U1341C-2H-7, 8.3 & 14.58 & 14.95 & Tie to & U1341A-3H-2, 49.4 & 14.49 & 14.95 \\
\hline U1341A-3H-6, 132.4 & 21.32 & 21.78 & Tie to & U1341B-3H-3, 12.9 & 21.33 & 21.78 \\
\hline U1341B-3H-6, 151.9 & 27.22 & 27.67 & Tie to & U1341C-4H-2, 4.1 & 26.04 & 27.67 \\
\hline U1341C-4H-7, 78.2 & 34.28 & 35.91 & Tie to & U1341A-5H-2, 99.5 & 33.99 & 35.91 \\
\hline U1341A-5H-6, 81.6 & 39.82 & 41.73 & Tie to & U1341B-5H-2, 60.4 & 39.30 & 41.73 \\
\hline U1341B-5H-7, 18.1 & 46.38 & 48.81 & Tie to & U1341C-6H-1, 140.2 & 44.90 & 48.81 \\
\hline U1341C-6H-7, 10.2 & 52.60 & 56.51 & Tie to & U1341A-7H-2, 84.2 & 52.84 & 56.51 \\
\hline U1341A-7H-6, 135.2 & 59.35 & 63.02 & Tie to & U1341B-7H-3, 103.1 & 60.23 & 63.02 \\
\hline U1341B-7H-6, 152.1 & 65.22 & 68.01 & Tie to & U1341C-8H-2, 47.8 & 62.98 & 68.01 \\
\hline U1341C-8H-6, 151.5 & 70.01 & 75.04 & Tie to & U1341A-9H-1, 70.1 & 70.20 & 75.04 \\
\hline U1341A-9H-5, 91.8 & 76.42 & 81.26 & Tie to & U1341B-9H-1, 79.6 & 76.00 & 81.26 \\
\hline U1341B-9H-6, 98.1 & 83.68 & 88.95 & Tie to & U1341C-10H-2, 9.5 & 81.59 & 88.95 \\
\hline U1341C-10H-6, 107.2 & 88.57 & 95.92 & Tie to & U1341B-10H-4, 100.7 & 90.21 & 95.92 \\
\hline U1341B-10H-7, 13.1 & 93.33 & 99.05 & Tie to & U1341C-11H-2, 145.9 & 92.46 & 99.05 \\
\hline U1341C-11H-5, 8.5 & 95.59 & 102.17 & Tie to & U1341B-11H-2, 49.0 & 96.19 & 102.17 \\
\hline U1341B-11H-6, 56.9 & 102.27 & 108.25 & Tie to & U1341C-12H-4, 3.5 & 100.03 & 108.25 \\
\hline U1341C-12H-6, 141.4 & 104.41 & 112.63 & Tie to & U1341B-12H-2, 103.7 & 106.24 & 112.63 \\
\hline U1341B-12H-6, 102.3 & 112.22 & 118.62 & Tie to & U1341C-13H-4, 62.8 & 110.13 & 118.62 \\
\hline U1341C-13H-7, 20.4 & 114.20 & 122.69 & Tie to & U1341A-14H-2, 65.8 & 119.16 & 122.69 \\
\hline U1341A-14H-6, 116.4 & 125.66 & 129.20 & Tie to & U1341C-15H-1, 105.2 & 125.05 & 129.20 \\
\hline U1341C-15H-6, 134.7 & 132.85 & 136.99 & Tie to & U1341B-14H-4, 105.4 & 128.25 & 136.99 \\
\hline U1341B-14H-7, 87.5 & 132.58 & 141.32 & Append to & U1341B-15H-1, 0.0 & 132.20 & 140.97 \\
\hline U1341B-15H-6, 130.8 & 141.01 & 149.78 & Tie to & U1341A-16H-3, 66.2 & 139.66 & 149.78 \\
\hline U1341A-16H-7, 22.6 & 145.23 & 155.34 & Tie to & U1341B-16H-3, 90.8 & 145.61 & 155.34 \\
\hline U1341B-16H-5, 30.5 & 148.00 & 157.74 & Tie to & U1341A-17H-2, 82.4 & 147.82 & 157.74 \\
\hline U1341A-17H-6, 122.9 & 154.23 & 164.15 & Tie to & U1341B-17H-3, 137.4 & 155.57 & 164.15 \\
\hline U1341B-17H-5, 77.0 & 157.97 & 166.54 & Tie to & U1341A-18H-1, 65.1 & 155.65 & 166.54 \\
\hline U1341A-18H-4, 34.7 & 159.85 & 170.74 & Tie to & U1341C-19H-3, 57.0 & 160.07 & 170.74 \\
\hline U1341C-19H-7, 5.0 & 165.55 & 176.22 & Tie to & U1341A-19H-1, 106.1 & 165.56 & 176.22 \\
\hline U1341A-19H-5, 103.4 & 171.53 & 182.19 & Tie to & U1341C-20H-3, 123.3 & 170.23 & 182.19 \\
\hline U1341C-20H-6, 144.8 & 174.95 & 186.91 & Tie to & U1341A-20H-1, 60.1 & 174.60 & 186.91 \\
\hline U1341A-20H-5, 48.2 & 180.48 & 192.79 & Tie to & U1341B-21H-1, 81.7 & 181.52 & 192.79 \\
\hline U1341B-21H-4, 126.2 & 186.46 & 197.73 & Tie to & U1341A-21H-1, 42.5 & 183.93 & 197.73 \\
\hline U1341A-21H-6, 120.1 & 192.20 & 206.01 & Tie to & U1341B-22H-3, 33.9 & 193.54 & 206.01 \\
\hline U1341B-22H-6, 128.3 & 198.98 & 211.45 & Tie to & U1341A-22H-1, 127.1 & 194.27 & 211.45 \\
\hline U1341A-22H-5, 97.2 & 199.97 & 217.15 & Tie to & U1341C-25H-1, 132.2 & 202.82 & 217.15 \\
\hline U1341C-25H-6, 145.1 & 210.45 & 224.78 & Tie to & U1341B-24H-2, 82.6 & 211.53 & 224.78 \\
\hline U1341B-24H-6, 4.9 & 216.75 & 230.00 & Tie to & U1341A-24H-2, 100.9 & 214.51 & 230.00 \\
\hline U1341A-24H-6, 24.3 & 219.74 & 235.24 & Tie to & U1341B-25H-2, 9.4 & 220.29 & 235.24 \\
\hline U1341B-25H-5, 13.3 & 224.83 & 239.78 & Tie to & U1341C-27H-2, 144.4 & 223.44 & 239.78 \\
\hline U1341C-27H-6, 34.3 & 228.34 & 244.68 & Tie to & U1341B-26H-2, 25.2 & 229.95 & 244.68 \\
\hline U1341B-26H-6, 138.9 & 237.09 & 251.81 & Tie to & U1341A-27H-2, 96.1 & 235.66 & 251.81 \\
\hline U1341A-27H-5, 70.2 & 239.90 & 256.05 & Tie to & U1341B-27H-2, 141.5 & 240.62 & 256.05 \\
\hline U1341B-27H-6, 47.4 & 245.67 & 261.11 & Tie to & U1341A-28H-2, 80.1 & 245.00 & 261.11 \\
\hline U1341A-28H-5, 82.5 & 249.53 & 265.64 & Tie to & U1341B-28H-2, 142.2 & 250.12 & 265.64 \\
\hline U1341B-28H-6, 106.1 & 255.76 & 271.28 & Tie to & U1341A-29H-2, 106.7 & 254.77 & 271.28 \\
\hline U1341A-29H-6 1203 & 260.90 & 277.41 & Tie to & U1341B-29H-4, 12.9 & 261.33 & 27741 \\
\hline
\end{tabular}


Table 18 (continued).

\begin{tabular}{|c|c|c|c|c|c|c|}
\hline \multirow[b]{2}{*}{$\begin{array}{l}\text { Hole, core, section, } \\
\text { interval }(\mathrm{cm})\end{array}$} & \multicolumn{2}{|c|}{ Depth } & & \multirow[b]{2}{*}{$\begin{array}{l}\text { Hole, core, section, } \\
\text { interval }(\mathrm{cm})\end{array}$} & \multicolumn{2}{|c|}{ Depth } \\
\hline & mbsf & $\begin{array}{c}\text { CCSF-D } \\
(\mathrm{m})\end{array}$ & & & mbsf & $\begin{array}{c}\text { CCSF-D } \\
(\mathrm{m})\end{array}$ \\
\hline U1341B-29H-6, 32.6 & 264.53 & 280.61 & Tie to & U1341A-30H-1, 153.7 & 263.24 & 280.61 \\
\hline U1341A-30H-6, 153.2 & 270.73 & 288.10 & Tie to & U1341B-30H-4, 33.8 & 271.04 & 288.10 \\
\hline U1341B-30H-6, 133.1 & 275.03 & 292.10 & Tie to & U1341A-31H-3, 34.9 & 274.55 & 292.10 \\
\hline U1341A-31H-6, 125.7 & 279.96 & 297.51 & Tie to & U1341B-31H-3, 86.9 & 279.57 & 297.51 \\
\hline U1341B-31H-6, 38.6 & 283.49 & 301.42 & Tie to & U1341A-32H-1, 94.1 & 281.64 & 301.42 \\
\hline U1341A-32H-4, 82.9 & 286.03 & 305.81 & Tie to & U1341B-32H-4, 92.2 & 287.76 & 305.81 \\
\hline U1341B-32H-6, 51.7 & 289.75 & 307.80 & Tie to & U1341A-33H-1, 40.0 & 290.60 & 307.80 \\
\hline U1341A-33H-6, 112.3 & 298.82 & 316.02 & Tie to & U1341B-33H-4, 88.7 & 298.69 & 316.02 \\
\hline U1341B-33H-5, 56.7 & 299.87 & 317.20 & Tie to & U1341A-34H-1, 40.0 & 300.10 & 317.20 \\
\hline U1341A-34H-7, 63.6 & 309.34 & 326.43 & Append to & U1341A-35H-1, 0.0 & 309.20 & 326.43 \\
\hline U1341A-35H-7, 17.9 & 318.38 & 335.60 & Tie to & U1341B-36H-1, 90.1 & 317.70 & 335.60 \\
\hline U1341B-36H-4, 128.1 & 322.58 & 340.48 & Tie to & U1341A-36H-3, 49.1 & 322.19 & 340.48 \\
\hline U1341A-36H-7, 20.9 & 327.61 & 345.90 & Tie to & U1341B-37H-1, 87.6 & 327.18 & 345.90 \\
\hline U1341B-37H-6, 44.5 & 334.24 & 352.97 & Tie to & U1341A-38H-2, 10.9 & 334.31 & 352.97 \\
\hline U1341A-38H-5, 154.3 & 340.24 & 358.91 & Tie to & U1341B-38H-3, 101.5 & 339.82 & 358.91 \\
\hline U1341B-38H-7, 5.4 & 344.85 & 363.95 & Tie to & U1341A-39H-2, 108.9 & 344.79 & 363.95 \\
\hline U1341A-39H-6, 81.8 & 350.52 & 369.67 & Tie to & U1341B-39H-4, 25.3 & 350.05 & 369.67 \\
\hline U1341B-39H-7, 49.0 & 354.79 & 374.41 & Append to & U1341B-40H, 0.0 & 354.80 & 374.42 \\
\hline
\end{tabular}

Table T19. Temperature data, Site U1341. (See table note.)

\begin{tabular}{lrcrrr}
\hline Core & $\begin{array}{c}\text { Depth } \\
(\mathrm{mbsf})\end{array}$ & $\begin{array}{c}\text { Thermal resistance } \\
\left(\mathrm{m}^{2} \mathrm{~K} / \mathrm{W}\right)\end{array}$ & $\begin{array}{c}T \\
\left({ }^{\circ} \mathrm{C}\right)\end{array}$ & $\begin{array}{c}T_{\mathrm{s}} \\
\left({ }^{\circ} \mathrm{C}\right)\end{array}$ & Remarks \\
\hline $323-\mathrm{U} 1341 \mathrm{~A}-$ & & & & & \\
$5 \mathrm{H}$ & 41.0 & 49.77 & 4.68 & 1.9 & Calm sea \\
$10 \mathrm{H}$ & 88.5 & 105.25 & 7.89 & 2.0 & Calm sea \\
$15 \mathrm{H}$ & 136.0 & 164.35 & 11.12 & 1.9 & Calm sea \\
\hline
\end{tabular}

Note: $T=$ formation temperature, $T_{\mathrm{S}}=$ seafloor temperature. 